CARLOS ROBERTO DE ALCKMIN DUTRA

\title{
O CONTROLE ABSTRATO DE CONSTITUCIONALIDADE SOB O ENFOQUE DOS PRINCÍPIOS PROCESSUAIS
}

Dissertação apresentada à Faculdade de Direito da Universidade de São Paulo para obtenção do título de Mestre em Direito

Orientador: Professor Titular Elival da Silva Ramos 


\section{O CONTROLE ABSTRATO DE CONSTITUCIONALIDADE SOB O ENFOQUE DOS PRINCÍPIOS PROCESSUAIS}

Dissertação apresentada à Faculdade de Direito da Universidade de São Paulo para obtenção do título de Mestre em Direito

Área de Concentração: Direito Constitucional

Orientador: Professor Titular Elival da Silva Ramos 
Autorizo a reprodução e divulgação total ou parcial deste trabalho, por qualquer meio convencional ou eletrônico, exclusivamente para fins de estudo e pesquisa, desde que citada a fonte.

São Paulo, de de 
NOME: DUTRA, Carlos Roberto de Alckmin

Título: O Controle Abstrato de Constitucionalidade sob o Enfoque dos Princípios Processuais

Dissertação apresentada à Faculdade de Direito da Universidade de São Paulo para obtenção do título de Mestre em Direito - Direito Constitucional sob a orientação do Professor Titular Elival da Silva Ramos.

Aprovado em:

Banca Examinadora:

Prof. Dr. Instituição:

Julgamento: Assinatura:

Prof. Dr. Instituição:

Julgamento: Assinatura:

Prof. Dr. Instituição:

Julgamento: Assinatura: 
Dedico este trabalho às mulheres que foram e são tão importantes na minha vida:

A Maria, Nossa Senhora, mãe de Jesus, pelo carinhoso afago que sempre recebi, especialmente nas situações mais difíceis;

Às minhas avós materna e paterna, pelos exemplos de vida;

À minha querida mãe, com muita saudade;

A Bárbara de Lourdes Dutra Éboli e Maria Auxiliadora Coelho de Aquino Tanaka, pelo carinho que tiveram comigo desde criança;

A Joana Cleide Villas Boas Cohn Éboli e Olga Maria do Val, advogadas exemplares, com as quais tive a oportunidade de aprender os primeiros passos da profissão;

E a essas duas criaturas tão doces, com as quais

Deus, com um sopro de amor e ternura, abençoou a minha existência: Carla e Geórgia! 
Agradeço ao estimado Prof. Elival da Silva Ramos, pela confiança em mim depositada e pela indispensável orientação. 


\section{RESUMO}

DUTRA, Carlos Roberto de Alckmin. O Controle Abstrato de Constitucionalidade sob o Enfoque dos Princípios Processuais. 2010, 241 f., Dissertação - UNIVERSIDADE DE SÃO PAULO, São Paulo, 2009.

Este estudo volta-se a averiguar a possibilidade de aplicação dos princípios constitucionais e gerais do processo ao controle abstrato de constitucionalidade (aqui abrangidas tanto as ações direta de inconstitucionalidade, como a declaratória de constitucionalidade e, ainda, a arguição de descumprimento de preceito fundamental), bem como a verificar em que medida a especialidade do processo objetivo de controle de constitucionalidade permite, ou não, a aplicação dos princípios gerais do processo e, ainda, a expor que, algumas vezes, as particularidades do processo do controle abstrato resultam na conformação de princípios próprios, diversos daqueles que informam os processos de índole subjetiva. Após uma introdução que busca trazer a lume as origens históricas do controle de constitucionalidade, apresentando o surgimento dos dois modelos de controle repressivo existentes (quais sejam, o norteamericano e o austríaco), bem como a conformação histórica e atual do sistema brasileiro, passa-se à análise dos princípios processuais à luz dos princípios constitucionais fixados na Constituição Federal de 1988. A abordagem é feita mediante o estudo de cada um dos princípios processuais aplicáveis, quais sejam: os princípios da especialidade; do juiz natural e da reserva de plenário; da ação ou demanda; da congruência; da especificação das normas; da causa de pedir aberta; da subsidiariedade; da livre investigação das provas; da indisponibilidade; do contraditório; da publicidade; da motivação e fundamentação das decisões; da irrecorribilidade; e da irrescindibilidade. O estudo é realizado mediante a análise tanto dos posicionamentos da doutrina como das decisões do Supremo Tribunal Federal que exploram mais diretamente o tema da aplicação dos princípios processuais em questão. Ao final, conclui-se que as normas processuais de índole constitucional têm, ao menos em princípio, aplicação no processo de controle de constitucionalidade, bem como que, em decorrência da natureza jurisdicional do processo de controle abstrato, a aplicação de determinados princípios gerais do processo traria inegáveis benefícios, maior segurança e clareza ao processo do controle de constitucionalidade.

Palavras-chave: Princípios processuais; Controle abstrato de constitucionalidade; Direito processual constitucional. 


\begin{abstract}
DUTRA, Carlos Roberto de Alckmin. The Abstract Constitutionality Control Enlightened by the Procedural Principles. 2010, 241 f., Dissertação - UNIVERSIDADE DE SÃO PAULO, São Paulo, 2009.
\end{abstract}

This study aims at checking the possibility of applying the constitutional and general principles of judicial proceedings to the abstract constitutionality control (i.e., judicial reviews covering direct unconstitutionality actions, as well as declaratory proceedings of constitutionality, and fundamental precept violation actions), as well as to check to what extent the specialty of the objective control of constitutionality actions permit, or do not permit, the application of general principles of the judicial proceedings and still, to expose that, sometimes, the peculiarities of the abstract control result in conformation of peculiar principles, different from those that inform legal actions of subjective character. After an introduction that aims at enlightening the historical origins of constitutionality control (judicial review), presenting the creation of two existing repressive control models (i.e., NorthAmerican and Austrian models), as well as the historical and present configuration of the Brazilian system, an analysis of the procedural principles is made facing the constitutional principles established in the Brazilian Federal Constitution of 1988. The approach is made by studying each one of the applicable procedural principles, such as: specialty principle, natural judge principle and full bench principle; as well as principles of legal actions or claims; congruence; specification or norms; open cause of action; subsidiary rights; free investigation of evidence or proof; inalienability; contradictory; publicity; motivation and recital of decisions, refuse to appeal; and irrevocability. This study is carried out by analysing both the doctrine's opinion as well as the decisions of the Brazilian Federal Supreme Court that exploit more directly the theme of procedural principles application being studied. Finally, it is concluded that the procedural norms of constitutional character at least have as a principle their application in the constitutionality control action, as well as that as a result of the jurisdictional nature of the concentrated control action, the application of certain general principles of the proceedings would bring undeniable benefits, greater safety and clearness to the constitutional control actions.

Key words: Procedural principles; Abstract constitutionality control; Procedural constitutional law. 


\section{LISTA DE ABREVIATURAS}

$\begin{array}{ll}\text { ADC } & \text { Ação Declaratória de Constitucionalidade } \\ \text { ADI } & \text { Ação Direta de Inconstitucionalidade } \\ \text { ADI-MC } & \text { Medida Cautelar em Ação Direta de Inconstitucionalidade } \\ \text { ADPF } & \text { Arguição de Descumprimento de Preceito Fundamental } \\ \text { AGU } & \text { Advocacia-Geral da União } \\ \text { Art. } & \text { Artigo (de lei ou outro ato normativo) } \\ \text { CDC } & \text { Código de Defesa do Consumidor } \\ \text { CESP } & \text { Constituição do Estado de São Paulo } \\ \text { CF } & \text { Constituição Federal } \\ \text { CPC } & \text { Código de Processo Civil } \\ \text { DJ } & \text { Diário da Justiça } \\ \text { EC } & \text { Emenda Constitucional } \\ \text { Inc. } & \text { Inciso (de artigo de lei ou outro ato normativo) } \\ \text { LOTC } & \text { Lei Orgânica do Tribunal Constitucional português } \\ \text { RISTF } & \text { Regimento Interno do Supremo Tribunal Federal } \\ \text { RTJ } & \text { Revista Trimestral de Jurisprudência } \\ \text { STF } & \text { Supremo Tribunal Federal }\end{array}$




\section{SUMÁRIO}

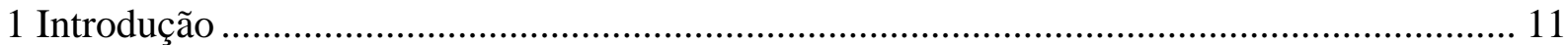

2 A Jurisdição Constitucional e o Controle de Constitucionalidade ........................................... 16

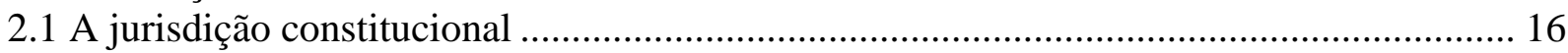

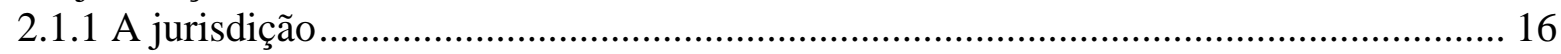

2.1.2 A jurisdição constitucional como atividade jurisdicional.............................................. 18

2.1.3 A jurisdição constitucional em sentido estrito (controle abstrato de constitucionalidade) como atividade jurisdicional ............................................................... 26

2.2 Processo e procedimento constitucionais .............................................................................. 37

2.2.1 Caracterização e crescente relevância do processo constitucional ................................ 37

2.2.2 O Direito Processual Constitucional........................................................................... 41

2.3 A evolução do controle de constitucionalidade ................................................................. 47

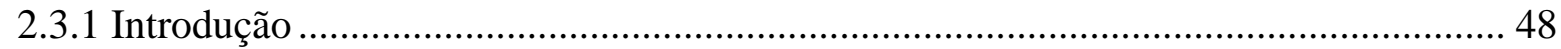

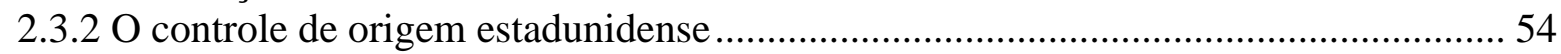

2.3.3 O controle de origem austríaca ...................................................................................... 57

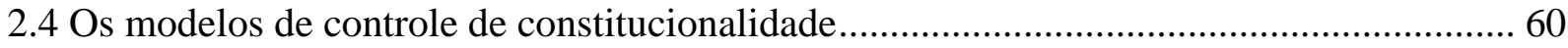

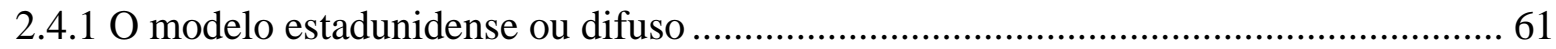

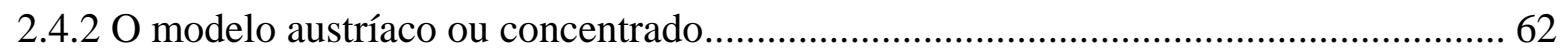

2.4.3 O modelo adotado no Brasil: uma breve evolução histórica ........................................ 63

3. Os Princípios Processuais e o Controle Abstrato de Normas .................................................. 74

3.1 Os princípios processuais................................................................................................... 74

3.2 Os princípios processuais e sua aplicação ao controle abstrato de leis e atos normativos . 81 3.2.1 O princípio da especialidade do processo de controle abstrato de normas e o princípio da subsidiariedade da aplicação das normas do processo comum........................................... 84 3.2.2 O princípio do juiz natural e o princípio ou cláusula de reserva de plenário [Constituição Federal, art. $5^{\circ}$ e art. 97; Lei federal n ${ }^{\circ}$ 9.868/99, art. $1^{\circ}$ (ADI e ADC); e Lei federal $n^{\circ}$ 9.882/99, art. $1^{\circ}$ (ADPF)] ……………………......................................... 93 3.2.2.1 Decisões monocráticas [Lei federal n ${ }^{\circ}$ 9.868/99, art. $4^{\circ}$ (ADI) e art. 15 (ADC); Lei federal n $\mathrm{n}^{\circ}$ 9.882/99, art. $4^{\circ}$ (ADPF)] ..................................................................... 98 3.2.2.2 Decisões cautelares [Lei federal $n^{\circ}$ 9.868/99, art. 10 (ADI), art. 21 (ADC); e Lei

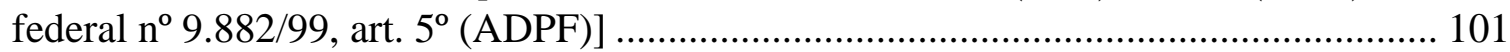
3.2.3 O princípio da ação ou da demanda. A inércia da jurisdição constitucional [Lei federal $n^{\circ}$ 9.868/99, art. $2^{\circ}$ (ADI) e art. 13 (ADC); Lei federal n ${ }^{\circ}$ 9.882/99, art. $2^{\circ}$ (ADPF)] ......... 103 3.2.3.1 O preceito fundamental que se considera violado (Lei federal no 9.882/99, art. $3^{\circ}$,

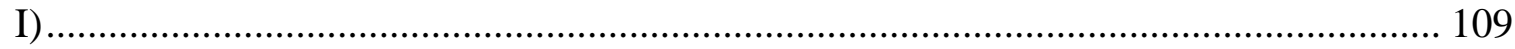
3.2.3.2 O dispositivo da lei ou do ato normativo impugnado [Lei federal $\mathrm{n}^{\circ} 9.868 / 99$, art. $3^{\circ}$, inc. I, primeira parte (ADI); e art. 14, inc. I, primeira parte (ADC)], ou, para o caso de ADPF, a indicação do ato questionado (Lei federal $n^{\circ}$ 9.882/99, art. $3^{\circ}$, II) ................... 112 3.2.3.3 Os fundamentos jurídicos do pedido em relação a cada uma das especificações (art. $3^{\circ}$, I, in fine (ADI), art. 14, I, in fine (ADC) 114 3.2.3.4 A prova da violação do preceito fundamental na ADPF (Lei federal no 9.882/99, art $3^{\circ}$, III). 
3.2.3.5 O pedido, com suas especificações [art. $3^{\circ}$, II (ADI) e art. 14, II (ADC), da Lei federal no 9.868/99; e art. 3으. IV, da Lei federal no 9.882/99 (ADPF)].......................... 115

3.2.3.5.1 Necessidade de impugnação de todo o complexo normativo referente ao dispositivo que se pretende declarar inconstitucional................................................... 118

3.2.3.5.2 Impugnação de todo o complexo normativo e o direito revogado ............... 121

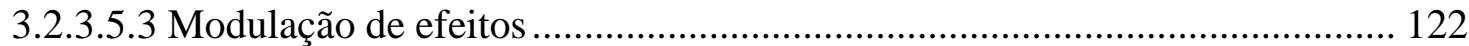

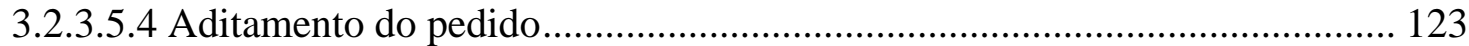

3.2.3.6 A existência de controvérsia judicial relevante sobre a aplicação da disposição objeto da ação declaratória de constitucionalidade (Lei federal no 9.868/99, art. 14, III)

3.2.3.7 A comprovação da existência de controvérsia judicial relevante sobre a aplicação do preceito fundamental que se considera violado (Lei federal $n^{\circ} 9.882 / 99$, art. $3^{\circ}, \mathrm{V}$ ) 126 3.2.4 O princípio da especificação das normas [Lei federal n ${ }^{\circ} 9.868 / 99$, art. $3^{\circ}$, I, primeira parte (ADI); e art. 14, I (ADC)], ou da indicação do ato questionado [(Lei federal $\mathrm{n}^{\circ}$ 9.882/99, art. $3^{\circ}$, II, (ADPF)] ……………………………......................................... 127

3.2.5 O princípio da causa de pedir aberta.......................................................................... 133

3.2.6 O princípio da congruência................................................................................... 141

3.2.6.1 Inconstitucionalidade consequencial por vínculo hierárquico............................. 145

3.2.6.2 Inconstitucionalidade consequencial por mácula nos atos normativos que servem

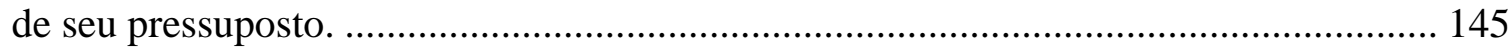

3.2.6.3 Inconstitucionalidade consequencial por vínculo de dependência ....................... 147

3.2.6.4 Inconstitucionalidade consequencial por vínculo de interdependência............... 147

3.2.7 O princípio da subsidiariedade na ADPF (Lei federal n ${ }^{\circ}$ 9.882/99, art. $4^{\circ}, \S 1^{\circ}$ ) ...... 149

3.2.8 O princípio da livre investigação das provas e o princípio inquisitivo [Lei federal $\mathrm{n}^{\circ}$

9.868/99, art. $9^{\circ}$, $\S \S 1^{\circ}$ a $3^{\circ}$ (ADI); art. 20, $\S \S 1^{\circ}$ a $3^{\circ}$ (ADC); e Lei federal $n^{\circ} 9.882 / 99$, art.

$\left.6^{\circ}, \S 1^{\circ}\right]$

3.2.8.1 Discussão de matéria relativa a interesses subjetivos específicos ........................ 166

3.2.8.2 Análise das prognoses legislativas................................................................... 169

3.2.9 O princípio da indisponibilidade [Lei federal n ${ }^{\circ}$ 9.868/99, art. $5^{\circ}$ (ADI) e art. 16

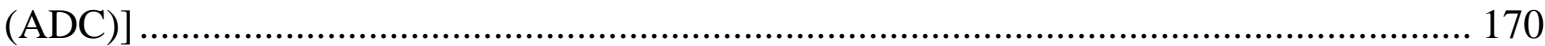

3.2.10 O princípio do contraditório [CF, art. $5^{\circ}$, LV; Lei federal ${ }^{\circ}$ 9.868/99, art. $6^{\circ}$, art. 7, § $2^{\circ}$, art. $8^{\circ}$, art. 10 , caput e $\S 1^{\circ}$, e art. 12 (todos acerca da ADI); art. 14 , III e art. 20 , $\S 1^{\circ}$ (ADC) e Lei federal ${ }^{\circ}$ 9.882/99, art. 5 , $\S 2^{\circ}$, art. $6^{\circ}$, caput e $\left.\S 1^{\circ}\right]$..................................... 172

3.2.10.1 A manifestação do Advogado-Geral da União ................................................... 194

3.2.10.2 A defesa da constitucionalidade da lei ou do ato normativo pelo Parlamento . 197 3.2.11 O princípio da irrecorribilidade (Lei federal $\mathrm{n}^{\circ}$ 9.868/99, art. 26 e Lei federal $\mathrm{n}^{\circ}$

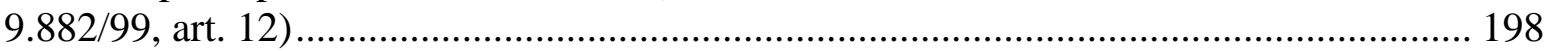

3.2.12 O princípio da publicidade (CF, art. 93, IX; Lei federal n ${ }^{\circ}$ 9.868/99, arts. 11, 21, §1 ${ }^{\circ}$

e 28; Lei federal $n^{0}$ 9.882/99) .................................................................................... 205

3.2.13 O princípio da motivação e da fundamentação das decisões judiciais (CF, art. 93, IX)

3.2.14 O princípio da irrescindibilidade (Lei federal no 9.868/99, art. 26 e Lei federal $\mathrm{n}^{\circ}$

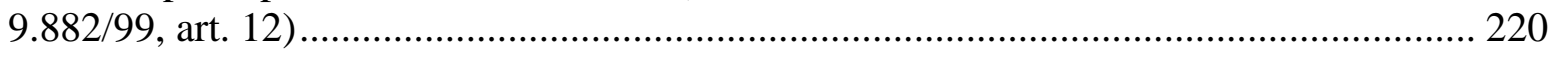

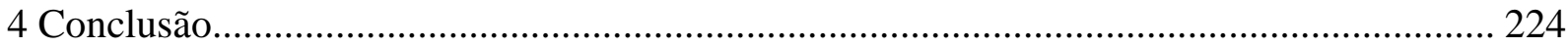




\section{Introdução}

No presente trabalho, abordarei um aspecto específico da jurisdição constitucional, qual seja, o processo por meio do qual se realiza o controle abstrato de constitucionalidade, analisando-o sob as luzes dos princípios processuais que o informam.

Mediante o desenvolvimento do tema, pretendo examinar a aplicabilidade dos princípios constitucionais do processo e dos princípios gerais do processo ao controle abstrato de constitucionalidade de leis e atos normativos e, ainda, averiguar a existência de princípios processuais próprios desta espécie de processo.

O controle abstrato, como se sabe, é exercido por meio de processo e procedimento especiais, previstos na própria Constituição e nas Leis federais $n^{\circ}$ 9.868/99 (ação direta de inconstitucionalidade e ação declaratória de constitucionalidade) e $n^{0}$ 9.882/99 (arguição de descumprimento de preceito fundamental), diferenciados daqueles dos processos de índole subjetiva.

Todavia, apesar de peculiar, configuraria o processo do controle abstrato uma forma especial de exercício da jurisdição, ainda que se possa questionar se há uma atividade jurisdicional nesses casos e, havendo, se estaria sujeito à incidência dos princípios constitucionais do processo ou mesmo aos princípios gerais do processo

Esclareça-se, desde logo, que a análise do tema será feita primordialmente a partir do plano do Direito Constitucional. Os institutos de Direito Processual serão examinados sumariamente, na medida em que se faça necessário à compreensão do tema e se mostre proveitoso à instrumentalização das normas constitucionais referentes ao controle abstrato de constitucionalidade.

O controle de constitucionalidade de leis e atos normativos é, indubitavelmente, um assunto assaz explorado pela doutrina nacional e estrangeira, revelando- 
se hoje, talvez, como o tema mais candente na seara do Direito Constitucional. Tal ocorre, certamente, pela importância que vêm assumindo as Cortes ou Tribunais Constitucionais (designação que se utiliza de forma abrangente, de modo a alcançar, também, tribunais que não possuem exclusivamente a tarefa de efetuar a verificação de constitucionalidade, como é o caso do nosso Supremo Tribunal Federal) no cenário político-institucional hodierno.

As análises doutrinárias tratam de inúmeras facetas do controle de constitucionalidade. Todavia, a interseção de temas de Direito Processual, em especial dos princípios gerais do processo, com o processo de controle abstrato de normas, bem como a perquirição acerca da existência de princípios próprios desta espécie de processo constitucional, recebeu pouca atenção dos pesquisadores nacionais.

Assim, o tema parece revelar especial interesse, em particular no Brasil, onde muitos dos princípios processuais estão inseridos no texto constitucional, sendo, portanto, ao que tudo indica, de observância obrigatória em todas as espécies de processo.

O processo do controle abstrato de normas é, inegavelmente, como mencionei acima, um processo de natureza especialíssima, com significativas diferenças em relação ao processo comum, de índole subjetiva. Dessa forma, a análise das peculiaridades de seu procedimento tende a tornar-lo acessível aos órgãos e entidades constitucionalmente legitimados ao seu manuseio, propiciando maior segurança aos seus operadores.

O enfoque proposto para abordar o tema é o situado a partir dos princípios processuais. Será feita uma análise, portanto, dos princípios processuais inseridos na Constituição que sejam aplicáveis à espécie, bem como dos princípios processuais, ainda que não inseridos na Carta Magna, que tenham implicações significativas no tema abordado.

Em virtude de excepcionar o princípio da separação dos Poderes, visto sob a sua fórmula clássica, a atividade de controle abstrato de constitucionalidade deve, necessariamente, estar prevista no próprio texto constitucional. 
Também em sede constitucional encontram-se diversos princípios processuais, como os do contraditório e da publicidade (CF, art. 93, IX), do devido processo legal (CF, art. 5, LIV) e da fundamentação das decisões (CF, art. 93, IX), dentre outros.

Dessa forma, a análise do tema deve ocorrer, indelevelmente, a partir da Constituição, na qual estão previstas as linhas mestras do controle de constitucionalidade, bem como os mais importantes princípios processuais.

Serão extensivamente analisadas as Leis federais $n^{\circ}$ 9.868/99, que disciplina a ação direta de inconstitucionalidade e a ação declaratória de constitucionalidade, e $n^{0}$ 9.882/99, que disciplina a arguição de descumprimento de preceito fundamental.

As normas de Direito Processual serão também objeto de estudo, na medida em que se apliquem subsidiariamente ao processo de controle abstrato ou auxiliem na sua instrumentalização.

Vislumbra-se, portanto, que a metodologia a ser empregada possui cunho eminentemente dogmático, pois procura analisar os institutos mencionados tal como conformados no direito positivo brasileiro.

Isso não impede que, em determinados e específicos temas, seja feita uma análise crítica dos institutos processuais do controle abstrato e da própria legislação que o rege, de modo a ser, eventualmente, sugerida a sua alteração, com a finalidade de aperfeiçoá-la e melhor conformá-la aos princípios e postulados constitucionais.

Portanto, complementarmente à análise dogmática, poderão ser efetuados enfoques zetéticos ${ }^{1}$, especialmente aqueles fornecidos pela Sociologia do Direito e

\footnotetext{
${ }^{1}$ Acerca dos enfoques teóricos zetético e dogmático, veja-se FERRAZ JÚNIOR, Tércio Sampaio. Introdução ao Estudo do Direito: Técnica, Decisão e Dominação. São Paulo, Atlas, 1996, p. 39-51.
} 
pela Ciência Política almejando a melhor e mais profunda compreensão do tema e de suas implicações.

Sob outro prisma, a abordagem será feita de forma analítica ${ }^{2}$, muito embora verificações a partir da jurisprudência do Supremo Tribunal Federal venham a ser realizadas, propiciando-se, assim, a melhor compreensão da matéria.

Desse modo, pretendo sugerir uma direção segura para a utilização do processo de controle abstrato de constitucionalidade, evidenciando as peculiaridades e diferenças deste em relação ao processo de índole subjetiva, cujo conhecimento é mais arraigado no seio da comunidade jurídica.

Verificarei os casos em que é possível a aplicação subsidiária de princípios e regras do processo comum ao processo de controle abstrato e em que medida deve ocorrer, bem como, ao inverso, as hipóteses em que essa aplicação mostra-se inviável, em decorrência das peculiaridades do processo objetivo.

Assim, contribuindo para uma escorreita utilização do instrumento processual de controle abstrato almejo, talvez até pretensiosamente, mas com propósito sincero, aperfeiçoar o próprio processo democrático de nosso país, pois a democracia requer, indiscutivelmente, participação e conhecimento dos instrumentos constitucionais existentes a fim de viabilizá-la.

Por fim, tenciona-se que, mediante a democratização das garantias constitucionais e dos instrumentos voltados à proteção da Constituição, sejam prestigiados, em verdade, os direitos fundamentais, pois se estará propiciando a possibilidade de, mediante a utilização daquele instrumental, conferir máxima efetividade às normas constitucionais que os preveem.

\footnotetext{
${ }^{2}$ Sobre a metodologia analítica e sintética, veja-se REALE, Miguel. Lições Preliminares de Direito. São Paulo, Saraiva, $18^{a}$ ed., 1981, p. 81-82.
} 
Em linhas gerais, são estes os objetivos aqui almejados. 


\title{
2 A Jurisdição Constitucional e o Controle de Constitucionalidade
}

\author{
2.1 A jurisdição constitucional
}

\subsubsection{A jurisdição}

O enfoque da doutrina processual tradicional vislumbra na jurisdição uma atividade do Estado pela qual este, substituindo a vontade das partes, faz atuar o direito no caso concreto $\left(\mathrm{CHIOVENDA}^{3}\right)$. Na visão de CARNELUTTI, a jurisdição caracteriza-se por ser exercida visando a solução de uma lide, isto é, o conflito de interesses qualificado pela pretensão de um dos interessados e pela resistência do outro. ${ }^{4} 5$

\footnotetext{
3 "Pode definir-se a jurisdição como a função do Estado que tem por escopo a atuação da vontade da lei por meio da substituição, pela atividade de órgãos públicos, da atividade de particulares ou de outros órgãos públicos, já no afirmar a existência da vontade da lei, já no torná-la, praticamente, efetiva.” In: CHIOVENDA, Giuseppe. Instituições de direito processual civil, v. II. São Paulo, Saraiva, 1943, p. 11.

4 "Pode acontecer que, diante da pretensão, o titular do interesse oposto se decida à sua subordinação. Em tal caso, a pretensão é bastante para determinar o desenvolvimento pacífico do conflito.

Mas, com freqüência não acontece assim. Então, à pretensão do titular de um dos interesses em conflito se opõe a resistência do titular do outro. Quando isto acontecer, o conflito de interesses se converte em litígio. Chamo de litígio ao conflito de interesses qualificado pela pretensão de um dos interessados e pela resistência do outro." In: CARNELUTTI, Francesco. Sistema de direito processual civil, v. I. São Paulo, Classic Book, 2000, p. 93.

${ }^{5}$ DINAMARCO expõe a diferença entre estas concepções de jurisdição da seguinte forma: "Para sustentar que o sistema processual teria por escopo a justa composição da lide, partia Carnelutti de uma importantíssima premissa metodológica, que era a da insuficiência do direito positivo para reger as concretas situações conflitivas da vida, ou seja, as lides. Antes da sentença não haveria direitos e obrigações e a missão do juiz seria acima de tudo a de completar o trabalho do legislador, produzindo a norma do caso em exame e com isso dando efetiva existência a direitos e obrigações entre as partes. Tal foi uma das manifestações da teoria unitária do ordenamento jurídico, para a qual o processo e o direito material situar-se-iam num mesmo plano e os direitos e obrigações não preexistiriam à sentença. A função criadora do processo, nessa perspectiva, consistiria no que Carnelutti denominou justa composição da lide. Tal é uma colocação puramente jurídica, dado que se limita, tanto quanto a de Chiovenda, a examinar o fenômeno processo como algo preordenado exclusivamente à vida do direito material. A grande diferença entre as duas teorias residia em que, enquanto para uma a norma do caso concreto receberia da sentença o seu acabamento final e antes desta os direitos inexistiriam (Carnelutti), para a outra o ordenamento jurídico é composto de dois planos distintos (teoria dualista, Chiovenda) e os direitos e obrigações preexistem à sentença, sendo por ela revelados com vista à concreta realização prática determinada pela norma também preexistente.” In: DINAMARCO, Cândido Rangel. Instituições de direito processual civil, v. I. $6^{a}$ ed., São Paulo, Malheiros, 2009, p. 130.
} 
Todavia, a insuficiência dessas teorias para a atual noção de processo foi bem evidenciada pela doutrina nacional e estrangeira. De fato, ressalta DINAMARCO que aquelas concepções "favoreciam o dogma da natureza técnica do processo como instrumento do direito material, sem conotações éticas ou deontológicas, além de dificultar a valorização dos meios alternativos de solução de conflitos”, ${ }^{\text {, }}$, sem que houvesse uma preocupação com os escopos sociais e políticos do processo, institutos que tiveram seu valor enfocado mais recentemente.

Referidas teorias tiveram um extraordinário valor científico e foram fundamentais para a evolução do Direito Processual Civil. Todavia, foram cunhadas para uma realidade social diversa da atual. Adaptam-se perfeitamente a um modelo de Estado liberal, no qual a racionalidade responde por uma suposta "perfeição” da lei e a interpretação parte não raro desta para a Constituição, restando ao juiz o papel de mero aplicador autômato da lei, personificado como “a boca da lei”, segundo a célebre expressão cunhada por MONTESQUIEU. ${ }^{7}$

Diante do papel que ora se espera do magistrado no processo, o de buscar interpretações a partir da Constituição de modo a utilizar-se do processo como instrumento voltado tanto à concretização dos princípios e ideais previstos no texto máximo como à defesa dos direitos fundamentais, sempre à luz da dignidade da pessoa humana, a própria técnica processual passa a ser interpretada de modo diverso.

Como bem elucida LUIZ GUILHERME MARINONI:

\footnotetext{
${ }^{6}$ DINAMARCO, Cândido Rangel. Instituições de direito processual civil, v. I. 6a ed., São Paulo, Malheiros, 2009, p. 130, para quem: "Constituem conquistas das últimas décadas a perspectiva sócio-política da ordem processual e a valorização dos meios alternativos. A descoberta dos escopos sociais e políticos do processo valeu também como alavanca propulsora da visão crítica de suas estruturas e do seu efetivo modo de operar, além de levar as especulações dos processualistas a horizontes antes estavam excluídos de sua preocupação.”

${ }^{7}$ No capítulo VI, do Livro Décimo Primeiro de seu O Espírito das Leis, Montesquieu retrata o Poder Judiciário como um poder temporário: "O poder de julgar não deve ser dado a um senado permanente, mas deve ser exercido por pessoas tiradas do seio do povo em certos momentos do ano, da maneira prescrita pela lei, para formar um tribunal que só dure o tempo que a necessidade requer.” In: MONTESQUIEU, Charles de Secondat. O Espírito das Leis. Tradução Cristina Murachco, São Paulo, Martins Fontes, 1996, p. 169. E acrescenta, conferindo a este poder uma natureza invisível e nula: "Desta forma, o poder de julgar, tão terrível entre os homens, como não está ligado nem a certo estado, nem a certa profissão, torna-se, por assim dizer, invisível e nulo. Não se têm continuamente juízes sob os olhos; teme-se a magistratura, e não os magistrados.”
} 
“A transformação da concepção de direito fez surgir um positivismo crítico, que passou a desenvolver teorias destinadas a dar ao juiz a real possibilidade de afirmar o conteúdo da lei comprometido com a Constituição. Nessa linha podem ser mencionadas as teorias dos direitos fundamentais, inclusive a teoria dos princípios, a técnica de interpretação de acordo, as novas técnicas de controle de constitucionalidade - que conferem ao juiz uma função 'produtiva', e não mais apenas de declaração de inconstitucionalidade - e a própria possibilidade de controle de constitucionalidade por omissão no caso concreto.

Ora, é pouco mais do que evidente que isso tudo fez surgir um outro modelo de juiz, sendo apenas necessário, agora, que o direito processual civil se dê conta disso e ponha um conceito de jurisdição que seja capaz de abarcar a nova realidade que se criou." 8

Portanto, a jurisdição, na atualidade, tem preocupação não somente com a técnica processual, mas, igualmente, com a consecução dos valores e objetivos previstos na Constituição e deve ser exercida sob as luzes dos princípios previstos em seu texto.

\subsubsection{A jurisdição constitucional como atividade jurisdicional}

Com mais razão ainda, no âmbito da jurisdição constitucional as definições tradicionais de jurisdição são ora insuficientes ora inaplicáveis. Deveras, no caso específico do controle abstrato de constitucionalidade, como se verá melhor adiante, não existem partes segundo a noção processual do termo, pois esta espécie de jurisdição dá origem a um processo objetivo, no qual não há defesa de interesses pessoais (ou de direitos subjetivos). Não seria, assim, apropriado aplicar neste contexto a noção de substituição da vontade das partes, nem sequer de lide, entendida como um conflito de interesses qualificado por uma pretensão resistida ${ }^{9}$.

\footnotetext{
${ }^{8}$ MARINONI, Luiz Guilherme. Teoria geral do processo. $3^{\mathrm{a}}$ ed., São Paulo, Revista dos Tribunais, 2008 , p. 24.

${ }^{9}$ É preciso ressaltar, todavia, a decrescente relevância metodológica do conceito de lide para a caracterização do processo. De fato, como esclarece DINAMARCO: “O conceito de lide e sua colocação metodológica destacada na ciência do processo eram muito caros aos juristas da Escola Processual de São Paulo em sua primeira fase entre os quais o prof. Alfredo Buzaid, que o manejou amplamente no Anteprojeto que depois se fez Código. No entanto, é de questionar se realmente existe lide em todo processo, mesmo em todo processo de jurisdição
} 
"Jurisdição" - ou "justiça" - constitucional é um termo utilizado de forma não uníssona pela doutrina. Questiona-se qual seria a sua abrangência. É certo que em seu contexto insere-se o controle de constitucionalidade. Mas que espécie de controle? Apenas o abstrato, ou também o concreto? E os instrumentos processuais previstos na Constituição com vistas à garantia das liberdades?

\section{HANS KELSEN utilizou-se da expressão jurisdição} constitucional para designar a forma de controle concentrado de constitucionalidade por ele formulada e, posteriormente, implementada pela Constituição da Áustria de 1920.

Os fundamentos daquilo que KELSEN chamou de proteção jurisdicional da Constituição - ou jurisdição constitucional - estão expostos em artigo por ele redigido e publicado inicialmente em francês, sob o título: La garantie juridictionelle de la Constitution (La justice constitutionelle), na Revue de Droit Public et Science Politique, 35/197-257, $1928 .^{10}$

Inicialmente, registre-se que KELSEN compreende a jurisdição constitucional (a garantia jurisdicional da Constituição) como um “elemento do sistema de técnicas que têm por fim garantir o exercício regular das funções estatais”. ${ }^{11}$ Garantir a constitucionalidade significa zelar pela regularidade das regras imediatamente subordinadas à Constituição.

contenciosa. Em processo penal não é exato que o Ministério Público, ou seja, a sociedade, tenha algum interesse na punição de inocentes, em conflito com o interesse do acusado à manutenção de seu status libertatis. Em processo civil mesmo, há certas causas que é de total indiferença a existência ou inexistência de conflito entre as atitudes das partes (o elemento formal da lide, resistência à pretensão), como é o caso das ações de anulação ou nulidade de casamento: com ou sem resistência, o processo é indispensável à consecução do objetivo do autor, havendo-se por ineficaz a confissão que o réu venha a fazer, ou mesmo eventual reconhecimento do pedido, e não se impondo ao revel o efeito da revelia (CPC, art. 320, inc. II). Questiona-se portanto a valia sistemática da lide como pólo metodológico em direito proessual, não sendo correto colocá-la ao centro de um sistema no qual vem ocupando essa colocação central $a$ ação, de tradições mais longevas.” In: DINAMARCO, Cândido Rangel. Vocabulário do processo civil, São Paulo, Malheiros, 2009, p. 181.

${ }^{10}$ Utilizarei a tradução para o português contida na obra KELSEN, Hans. Jurisdição Constitucional. São Paulo, Martins Fontes, 2003, p. 121-186.

${ }^{11}$ Ibidem, p. 123-124. 
A Constituição, para KELSEN, ocupa um lugar de extrema relevância no ordenamento jurídico. De fato, esclarece que "a noção de Constituição conservou um núcleo permanente: a idéia de um princípio supremo determinando a ordem estatal inteira e a essência da comunidade constituída por essa ordem”. ${ }^{12}$

E acrescenta, a sublinhar o papel de destaque que a Constituição assume no ordenamento jurídico:

"Como quer que se defina a Constituição, ela é sempre o fundamento do Estado, a base da ordem jurídica que se quer apreender. O que se entende antes de mais nada e desde sempre por Constituição - e, sob esse aspecto, tal noção coincide com a de forma do Estado - é um princípio em que se exprime juridicamente o equilíbrio das forças políticas no momento considerado, é a norma que rege a elaboração das leis, das normas gerais para cuja execução a atividade dos organismos estatais, dos tribunais e das autoridades administrativas. Essa regra para a criação das normas jurídicas essenciais do Estado, a determinação dos órgãos e do procedimento da legislação, forma a Constituição no sentido próprio, original e estrito da palavra. Ela é a base indispensável das normas jurídicas que regem a conduta recíproca dos membros da coletividade estatal, assim como das que determinam os órgãos necessários para aplicá-las e impô-las, e a maneira como devem proceder, isto é, em suma, o fundamento da ordem estatal.”13

Assevera que as modernas técnicas de preservação da Constituição podem ser exercidas de maneira preventiva ou repressiva, tendo a última uma importância mais significativa que a primeira, pois, dentre estas técnicas, a que se destina à "anulação do ato inconstitucional é a que representa a principal e mais eficaz garantia da Constituição”. 14

\footnotetext{
${ }^{12}$ KELSEN, Hans. Jurisdição Constitucional. São Paulo, Martins Fontes, 2003, p. 130.

13, Ibidem, p. 130-131.

${ }^{14}$ Ibidem, p. 148.
} 
Em defesa da existência de um órgão encarregado de zelar pela constitucionalidade das leis, KELSEN procura desmistificar as críticas feitas à criação de tal instância. Desse modo, afirma que: a) a opção de conferir a fiscalização da regularidade das leis ao próprio órgão que as produziu - isto é, ao Parlamento - seria o procedimento mais contraindicado, cabendo tal fiscalização a um órgão independente tanto do Parlamento como de qualquer outra autoridade estatal, qual seja, o Tribunal Constitucional ${ }^{15}$; e b) a instituição de um órgão com essas características não infringiria o princípio da separação dos Poderes, pois, embora organizado em forma de tribunal, “o órgão a que é confiada a anulação das leis inconstitucionais não exerce uma função verdadeiramente jurisdicional”, mas, sim, uma função legislativa, pois a anulação da lei seria o mesmo que a sua elaboração, mas em sentido negativo. Dessa forma, o órgão encarregado de tal tarefa não se inseriria no Poder Judiciário, mas, sim, no Legislativo. Haveria, assim, a separação das funções legislativas em dois órgãos, com vista a “impedir a concentração de um poder excessivo nas mãos de um só órgão concentração que seria perigosa para a democracia -, mas também para garantir a regularidade do funcionamento de diversos órgãos”. 16

Privilegiando o ponto de vista subjetivo da função ANDRÉ RAMOS TAVARES, afirma que a jurisdição constitucional consistiria na defesa da Constituição em todos os seus aspectos, desde que operada por um tribunal no exercício de jurisdição. Todavia, entende que, para que se possa falar em exercício da jurisdição constitucional, há necessidade de isolar a defesa da Constituição como função exclusiva. ${ }^{17}$

Por outro lado, entende o professor da Pontifícia Universidade Católica de São Paulo que o termo Justiça Constitucional teria um espectro um pouco maior,

\footnotetext{
15 “O órgão legislativo se considera na realidade um livre criador do direito, e não um órgão de aplicação do direito, vinculado pela Constituição, quando teoricamente o é sim, embora numa medida relativamente restrita. Portanto não é com o próprio Parlamento que podemos contar para efetuar sua subordinação à Constituição. É um órgão diferente dele, independente dele e, por conseguinte, também de qualquer outra autoridade estatal, que deve ser encarregado da anulação de seus atos inconstitucionais - isto é, uma jurisdição ou tribunal constitucional.” In: KELSEN, Hans. Jurisdição Constitucional. São Paulo, Martins Fontes, 2003, p. 150.

${ }^{16}$ Ibidem, p. 151-152.

${ }^{17}$ TAVARES, André Ramos. Teoria da justiça constitucional. São Paulo, Saraiva, 2005, p. 145.
} 
pois mesmo um tribunal que não tenha a exclusiva competência de atuar como guardião da Constituição pode se caracterizar com um órgão da Justiça Constitucional:

“A exigência da atuação exclusiva como curador da Constituição levaria a desconsiderar um tribunal como a Corte Suprema norte-americana, que não seria propriamente um Tribunal Constitucional, embora ninguém duvide que exerça Justiça Constitucional. Seria, ainda, o caso do Supremo Tribunal Federal no Brasil. O mesmo ocorreria com o Tribunal criado pela Constituição da Romênia, de 1923, que apesar de ser instância única, era um Tribunal supremo. Consoante essa tese, nenhum tribunal supremo de uma estrutura judiciária, ainda que contemple uma câmara ou seção exclusivamente constitucional, deveria ser considerado Tribunal Constitucional em sentido estrito.”18

Embora evidenciando a inconveniência de se atribuir ao Tribunal ou Corte Constitucional atividades diversas do controle de constitucionalidade de leis, mais adiante TAVARES deixa claro que nos "casos dos tribunais supremos é inquestionável que exerçam Justiça Constitucional em tempo parcial, ao lado do exercício de competências outras (normalmente recursais) que não são adequadas à natureza de um Tribunal Constitucional [...]”. ${ }^{19}$ Esclarece que o tribunal constitucional deve ser identificado pelo exercício de funções típicas, em especial do controle de constitucionalidade de leis, pois o caráter exclusivo, e com monopólio, não seria elemento imprescindível para a existência de um tribunal constitucional. ${ }^{20}$

Neste sentido, seria inegável que o Supremo Tribunal Federal brasileiro exerce, efetivamente, a jurisdição constitucional, embora em caráter não exclusivo. ${ }^{21}$

\footnotetext{
18 TAVARES, André Ramos. Teoria da justiça constitucional. São Paulo, Saraiva, 2005, p. 157.

${ }^{19}$ Ibidem, p. 157-158.

${ }^{20}$ Ibidem, p. 158-159.

${ }^{21}$ No mesmo sentido o entendimento de NELSON NERY JUNIOR, com uma visão crítica do atual sistema: “No atual sistema brasileiro, temos realmente uma Corte Constitucional federal, consubstanciada no STF, conclusão que se extrai da competência que o legislador constituinte conferiu àquela corte de justiça. Verificamos, entretanto que o perfil constitucional de nosso Tribunal Federal Constitucional não se nos afigura o melhor, porquanto não nos parece que um órgão do Poder Judiciário possa apreciar, em último e definitivo grau, as questões constitucionais que lhe são submetidas de forma abstrata (v.g., controle da constitucionalidade por meio de ADIn e de ADPF), cujos membros são nomeados pelo Presidente da República sem critério de proporcionalidade ou representatividade dos demais poderes.” In: NERY JUNIOR, Nelson. Princípios do processo civil da constituição federal. 9a ed., São Paulo, Revista dos Tribunais, 2009, p. 44.
} 
JOSÉ AFONSO DA SILVA comunga da ideia de que a jurisdição constitucional consistiria essencialmente no controle jurisdicional da constitucionalidade das leis, isto é, na missão de solucionar os conflitos entre normas jurídicas ordinárias (ou complementares) e a Constituição. Mas não se esgotaria aí, englobando também toda atuação dos tribunais judiciários destinados a assegurar a observância das normas constitucionais, abarcando:

“a) conflitos entre o Estado e indivíduos ou grupos, desde que estes reclamem ter havido violação de liberdades ou direitos fundamentais; b) apreciação judicial da constitucionalidade das leis; c) conflitos entre os órgãos do governo; d) conflitos entre entidades intraestatais autônomas.”22

DINAMARCO explica que as relações entre Constituição e processo ocorrem em dois sentidos vetoriais:

“a) no sentido Constituição-processo, tem-se a tutela constitucional deste e dos princípios que devem regê-lo, alçados a nível constitucional; b) no sentido processo-Constituição, a chamada jurisdição constitucional, voltada ao controle de constitucionalidade das leis e atos normativos e à preservação de garantias oferecidas pela Constituição ('jurisdição das liberdades'), mais toda a idéia de instrumentalidade processual em si mesma, que apresenta o processo como sistema estabelecido para a realização da ordem jurídica, constitucional inclusive.”23

Verifica-se, portanto, que DINAMARCO destaca nas relações entre Constituição e processo tanto os princípios processuais como a jurisdição constitucional e a própria ideia de instrumentalidade do processo.

No âmbito da jurisdição constitucional, entende o ilustre processualista estar incluído não somente o controle de constitucionalidade, mas também, citando, neste ponto, CAPPELLETTI, "um arsenal de processos especiais destinados a assegurar a certos direitos fundamentais do homem uma tutela jurisdicional particularmente

${ }^{22}$ SILVA, José Afonso da. Da jurisdição constitucional no Brasil e na América Latina. Revista da Procuradoria-Geral do Estado. São Paulo, dez. 1978 / dez. 1979, p. 113.

${ }^{23}$ DINAMARCO, Cândido Rangel. A Instrumentalidade do Processo. $13^{\mathrm{a}}$ ed., São Paulo, Saraiva, 2008, p. 2627. 
forte e diferenciada”. ${ }^{24}$ Este “arsenal” de processos especiais configuraria a jurisdição constitucional das liberdades da qual, no Brasil, são exemplos típicos o mandado de segurança, o habeas corpus, o mandado de injunção e o habeas data.

De fato, para o mestre italiano, a jurisdição ou justiça constitucional - termos que parece usar como sinônimos - não se restringiria ao controle jurisdicional de constitucionalidade:

"Na verdade, parece oportuno precisar, desde agora, que o tema do controle jurisdicional de constitucionalidade de leis não pode, certamente, identificarse com a jurisdição ou justiça constitucional, a Verfassungsgerichtsbarkeit dos alemães. Ele, ao contrário, não representa senão um dos vários possíveis aspectos da assim chamada 'justiça constitucional' [...].", 25

CANOTILHO também adota conceito amplo de jurisdição constitucional. Define a justiça constitucional como o "complexo de actividades jurídicas desenvolvidas por um ou vários órgãos jurisdicionais, destinadas à fiscalização da observância e cumprimento das normas e princípios constitucionais vigentes”. ${ }^{26}$

Entende o lente de Coimbra que o conhecimento da justiça constitucional requer a percepção de sua evolução histórica. Enumera, então, como expressões históricas mais significativas na formação da justiça constitucional: a) a garantia contenciosa contra atos da administração; b) a expansão da judicial review do direito americano; c) a justiça do Estado (solução jurisdicional entre os poderes do Estado); d) a tradição de "justiça política” ou de "direito do Estado"; 27 e) a ideia de regularidade de formação dos órgãos constitucionais; f) a ideia de amparo; e, por fim g) a "justiça constitucional”. ${ }^{28}$

\footnotetext{
${ }^{24}$ DINAMARCO, Cândido Rangel. A Instrumentalidade do Processo. 13a ed., São Paulo, Saraiva, 2008, p. 30.

${ }^{25}$ CAPPELLETTI, Mauro. O Controle judicial de constitucionalidade das leis no direito comparado. Rio Grande de Sul, Sérgio Fabris Editor, 1999, p. 23-24.

${ }^{26}$ CANOTILHO, José Joaquim Gomes. Direito constitucional e teoria da Constituição. $7^{\mathrm{a}}$ ed., Coimbra, Almedina, 2003, p. 892.

27 “'A atribuição, a um órgão jurisdicional, do conhecimento e julgamento de 'atentados à constituição', radica na velha idéia anglo-saxónica do impeachment, isto é, na idéia de crimes de responsabilidade cometidos pelos órgãos supremos do Estado ('alta traição', ‘atentados à constituição', ‘delictos ministeriais').” In: Ibidem, p. 893.

${ }^{28}$ Ibidem, p. 892-894.
} 
Salienta, ainda, a importância na formação da ideia de justiça constitucional moderna da concepção austríaca de justiça constitucional autônoma (Verfassungsgerichtsbarkeit), a qual pressupõe um tribunal criado especialmente com a função de controlar, de forma concentrada, desvinculada de um caso concreto, a constitucionalidade das leis.

ALEXANDRE DE MORAES, em trabalho monográfico acerca da jurisdição constitucional e dos tribunais constitucionais ${ }^{29}$, coloca como modelos de justiça constitucional a Suprema Corte Americana, o Tribunal Constitucional Austríaco, o Conselho Constitucional Francês, o Tribunal Constitucional Alemão e o Tribunal Constitucional Português. Refere-se à jurisdição constitucional brasileira discorrendo acerca do Supremo Tribunal Federal e de suas competências, destacando a realização do controle de constitucionalidade, preventivo e repressivo. Em relação a este último, aborda a ação direta de inconstitucionalidade, a ação direta de inconstitucionalidade por omissão, a ação declaratória de constitucionalidade e a ação direta de inconstitucionalidade interventiva ${ }^{30}$. Inclui, outrossim, no objeto de sua obra, o controle difuso de constitucionalidade e a proteção aos direitos fundamentais, cuidando, nesse tópico, da arguição de descumprimento de preceito fundamental.

Conclui sua tese com uma proposta de redução das competências do Supremo Tribunal Federal, mediante a transferência daquelas de caráter ordinário ao Superior Tribunal de Justiça. Assim, ao Supremo Tribunal Federal seriam reservadas apenas as competências atinentes à jurisdição constitucional (guarda da Constituição) que, para MORAES, seriam as seguintes: a) o controle de constitucionalidade das leis e atos normativos; b) proteção da supremacia dos direitos e garantias fundamentais (por meio da arguição de descumprimento de preceito fundamental); c) o controle da federação (conflitos entre União e os Estados, a União e o Distrito Federal, ou entre uns e

\footnotetext{
${ }^{29}$ MORAES, Alexandre de. Jurisdição Constitucional e Tribunais Constitucionais. $2^{\mathrm{a}}$ ed., São Paulo, Atlas, 2003.

${ }^{30}$ Todavia, ao que tudo indica, a representação interventiva não tem a natureza de ação, motivo pelo qual não será objeto de análise no presente trabalho, que se volta à análise do controle jurisdicional abstrato de constitucionalidade.
} 
outros); d) a garantia da regularidade do regime democrático (matérias de Direito Eleitoral, hoje de competência do Tribunal Superior Eleitoral, como inelegibilidades, a expedição e a anulação de diplomas, a perda de mandatos eletivos etc.); e e) a garantia do Estado de Direito e a preservação da separação dos Poderes. ${ }^{31}$

Como se pode perceber, a jurisdição constitucional pode ser vista em sentido próprio e em um sentido estrito. No sentido próprio (amplo), abarca não só o controle de constitucionalidade, incidental ou principal, como também as garantias constitucionais e demais instrumentos processuais previstos no texto constitucional com vistas a propiciar a proteção judicial dos direitos fundamentais e de outros direitos previstos no texto constitucional; em sentido estrito, a jurisdição constitucional diz respeito apenas ao controle abstrato de constitucionalidade.

\subsubsection{A jurisdição constitucional em sentido estrito (controle abstrato de constitucionalidade) como atividade jurisdicional}

Resta ainda uma questão a responder: a jurisdição constitucional caracterizar-se-ia efetivamente como exercício da jurisdição?

Embora reconhecendo o Tribunal Constitucional português como verdadeiro tribunal, VITALINO CANAS nega que exerça função jurisdicional:

"Não é raro, ainda hoje, procurar estabelecer-se um nexo incindível entre tribunal e função jurisdicional. Trata-se, contudo, de uma construção a abandonar. Como foi dito por alguém, nada permite afirmar que os tribunais sejam uma espécie de Rei Midas que converta em jurisdicional tudo aquilo em que toca. Na verdade temos por certo que o facto de o órgão em causa

\footnotetext{
${ }^{31}$ MORAES, Alexandre de. Jurisdição Constitucional e Tribunais Constitucionais. $2^{\mathrm{a}}$ ed., São Paulo, Atlas, 2003., p. 300-302.
} 
ser um verdadeiro tribunal de forma alguma pode implicar inelutavelmente que as funções por ele desempenhadas tenham caráter jurisdicional.,32 33

Entre nós, o debate não é novo.

Analisando a ação direta de inconstitucionalidade interventiva, precursora da atual ação direta de inconstitucionalidade (conhecida também como ação direta genérica, em virtude de poder, ao contrário da anterior, ser manejada para combater qualquer espécie de violação à Constituição), BUZAID assevera que a função exercida aí pelo Supremo Tribunal Federal, em face da violação dos princípios constitucionais sensíveis, é inegavelmente jurisdicional:

“A função que o Supremo Tribunal Federal exerce, na apreciação dos princípios fundamentais acima referidos, não é de caráter administrativo, nem legislativo; é tipicamente jurisdicional. Trata-se, porém, de jurisdição constitucional, porque seu objeto não é resolver relações jurídicas de direito privado ou de direito público, mas compor conflito de normas do Estado, que transcendem os limites de suas atribuições. O que dá lugar à provocação do Supremo é, portanto, a existência de um litígio constitucional, proposto pelo Procurador em ação direta." 34

Contrariamente, em voto proferido na ação rescisória $n^{\circ}$ 878/SP, na qual se discutia a possibilidade de o acórdão proferido no seio de ação direta de inconstitucionalidade ser objeto daquela espécie de ação, o Ministro MOREIRA ALVES qualificou a ação direta como um meio de controle político da Constituição, deferido em caráter excepcionalíssimo ao Supremo Tribunal Federal, negando-lhe, por este motivo, a

${ }^{32}$ CANAS, Vitalino. Os processos de fiscalização da constitucionalidade e da legalidade pelo Tribunal Constitucional: Natureza e princípios estruturantes. Coimbra, Coimbra Editora, 1986, p. 20-21.

${ }^{33}$ No mesmo sentido, veja-se a opinião de RODRIGO LOPES LOURENÇO: "Verifica-se, destarte, que, do ponto de vista material, a ação direta de inconstitucionalidade não é, propriamente, uma ação. O procedimento abstrato de controle de constitucionalidade tem, em verdade, função legislativa-negativa, porque visa, conforme já afirmado, exclusivamente, à exclusão da norma impugnada do ordenamento jurídico. O eminente GOMES CANOTILHO ensinou que 'o controle com eficácia erga omnes é próprio do controle concentrado e corresponde ao exercício de uma Verwerfungskompetenz (competência de rejeição). O Tribunal Constitucional ou órgão correspondente afirma-se como 'defensor da constituição', legislando, negativamente, ou seja, eliminando do ordenamento jurídico a norma inconstitucional.” In: LOURENÇO, Rodrigo Lopes. Controle de constitucionalidade à luz da jurisprudência do Supremo Tribunal Federal. Rio de Janeiro, Forense, 1998, p. 23.

${ }^{34}$ BUZAID, Alfredo. Da ação direta de declaração de inconstitucionalidade no direito brasileiro. São Paulo, Saraiva, 1958, p. 112-113. 
natureza jurisdicional. Opinou no sentido da impossibilidade de sujeitar o acórdão proferido em ação direta à rescisória em decorrência das peculiaridades que constituem a ação direta de inconstitucionalidade, que a configurariam como instrumento de controle político e não como meio de prestação jurisdicional. ${ }^{35}$

\section{Em outra oportunidade, o Ministro MOREIRA ALVES}

sedimentou sua posição no sentido de que, na representação de inconstitucionalidade de lei em tese, não havia exercício de função jurisdicional, mas, sim, controle de caráter político, como demonstra o seguinte trecho de seu voto, proferido na Representação no 1.405/AC:

"A tese do parecer, que é exposta com erudição e argúcia se robustece em face da circunstância de que, na representação de inconstitucionalidade da lei em tese, não há o exercício de função jurisdicional - prestação de jurisdição -, como sucede no controle difuso de constitucionalidade, sendo certo, por outro lado, que, em nosso sistema constitucional, o Poder Judiciário é nacional, e vem estruturado pela Constituição Federal, que - ao contrário do que ocorre na representação interventiva - só atribui a esta Corte o processo objetivo, e de caráter político e não jurisdicional, da representação de inconstitucionalidade de lei em tese." 36

A polêmica também ocorreu em outras partes. Mesmo KELSEN, à época da formulação de seu modelo de tribunal constitucional, teve de enfrentar a questão. CARL SCHMITT, em obra que questiona qual órgão deve ser o guardião da Constituição, arrola dentre os argumentos enfeixados para desqualificar um tribunal como

35 Ação Rescisória no 878/SP, Tribunal Pleno. DJ 06/06/1980, p. 4.134, RTJ 94/49-60: “Sr. Presidente, eu também, data venia, acolho a preliminar de impropriedade da ação.

A meu ver, a ação direta de declaração de inconstitucionalidade é um meio de controle político da Constituição, que é deferido, em caráter excepcionalíssimo, a esta Suprema Corte.

O eminente Procurador-Geral da República é o titular dessa representação, apenas para o efeito de provocar, ou não, o Tribunal, porque ele, como órgão político - já que se trata de ação de natureza política, pois o que se decide são os limites da atuação de dois Poderes conjugados ao elaborar uma lei -, pode encaminhar, ou não, o pedido. E mais. Ainda que seja contrário ao próprio pedido que encaminha, o regimento só lhe defere a possibilidade de dar parecer em contrário.

Essas peculiaridades e o fato de que o próprio Supremo pode dispensar as informações do Congresso ou da Assembléia estão a demonstrar, a meu ver, o caráter excepcional dessa ação.

E por ser ela instrumento de controle político da constitucionalidade da lei em tese, e não estritamente meio de prestação jurisdicional, não se me afigura possível sujeitá-la a ação rescisória prevista no Código de Processo Civil”. In: MENDES, Gilmar Ferreira. Moreira Alves e o controle de constitucionalidade no Brasil. São Paulo, Celso Bastos Editor, 2000, p. 173 (grifos nossos).

${ }^{36}$ Ibidem, p. 200 (grifos nossos). 
titular desta função, o de que a jurisdição constitucional não se qualificaria, na realidade, como exercício da jurisdição. ${ }^{37} 38$

Para demonstrar a natureza das funções exercidas pelo tribunal constitucional, KELSEN expõe a distinção entre as atividades de elaboração e de simples anulação das leis:

“A anulação de uma lei se produz essencialmente como aplicação das normas da constituição. A livre criação que caracteriza a legislação está aqui quase completamente ausente.

$[\ldots]$

E é precisamente nisso que sua função se parece com a de qualquer outro tribunal em geral: ela é principalmente aplicação e somente em pequena parte criação do direito.”39

Assim, apesar de o produto da atividade do tribunal constitucional se assemelhar a um ato legislativo, o exercício de sua atividade se assemelha àquele realizado pelos tribunais. Desta feita, conclui KELSEN afirmando que a atividade dos tribunais constitucionais é efetivamente jurisdicional, aplicando-se-lhe os mesmos princípios que são válidos para a organização dos tribunais ou dos órgãos executivos. ${ }^{40}$

KELSEN retoma a questão em artigo publicado em $1930-31^{41}$, escrito especificamente com a finalidade de responder a SCHMITT, no qual afirma que os argumentos por ele defendidos:

"partem de um pressuposto errôneo de que entre funções jurisdicionais e funções políticas existiria uma contradição essencial, e que particularmente a decisão sobre a constitucionalidade de leis e a anulação de leis

\footnotetext{
${ }^{37}$ SCHMITT, Carl. O guardião da Constituição. Tradução Geraldo de Carvalho, Belo Horizonte, Del Rey, 2007, p. 1-102/193-234.

${ }^{38}$ SCHMITT entende que a guarda da Constituição deveria ser conferida ao Füher, Chefe de Estado do Reich alemão.

${ }^{39}$ KELSEN, Hans. Jurisdição Constitucional. São Paulo, Martins Fontes, 2003, p. 153.

40 "É, por conseguinte, efetivamente jurisdicional. Portanto os mesmos princípios essenciais que presidem sua constituição são válidos para a organização dos tribunais ou dos órgãos executivos”. In: Ibidem, p. 153.

${ }^{41}$ KELSEN, Hans. Wer soll der Hüter der Verfassung sein?, Die Justiz. Heft 11-12, v. VI, 1930-31, p. 576628. Utilizei a versão portuguesa já mencionada. In: KELSEN, Hans. Jurisdição Constitucional. São Paulo, Martins Fontes, 2003, p. 237-298.
} 
inconstitucionais seria um ato político, donde se deduz que tal atividade já não seria propriamente jurisdicional”. ${ }^{42}$

Argumenta que o termo político, por natureza polissêmico, teria sido mal utilizado para expressar apenas a atividade do legislador - esta seria considerada criação produtiva do direito e, a jurisdição, mera aplicação deste -, o que se revelaria uma noção errônea, porque:

"Na medida em que o legislador autoriza o juiz a avaliar, dentro de certos limites, interesses contrastantes entre si, e decidir conflitos em favor de um ou outro, está lhe conferindo um poder de criação do direito, e portanto um poder que dá à função judiciária o mesmo caráter 'político' que possui ainda que em menor medida - a legislação.”43

Assevera que entre o caráter político da legislação e o da jurisdição, há apenas uma diferença quantitativa e não qualitativa. ${ }^{44}$

E conclui que, se a atividade realizada nos tribunais constitucionais tem um caráter muito mais político do que a dos demais tribunais, nem por isso ele deixa de ser tribunal e a sua função deixa de ser jurisdicional. ${ }^{45}$

Por fim, retoma o tema de não haver diferença qualitativa entre lei e sentença, pois ambas destinam-se à produção de direito. Embora reconhecendo a decisão do tribunal como ato normativo (isto é, de produção do direito e não mera aplicação da lei, na qual o juiz se mostra como um mero autômato - tal qual na concepção clássica de

\footnotetext{
${ }^{42}$ KELSEN, Hans. Jurisdição Constitucional. São Paulo, Martins Fontes, 2003, p. 250.

${ }^{43}$ Ibidem, p. 251 (grifo nosso).

${ }^{44}$ Ibidem, p. 251.

${ }^{45}$ Ibidem, p. 252-253: “Segundo Schmitt as questões 'políticas’ não são objeto de jurisdição. Pois bem, tudo que se pode dizer do ponto de vista de um exame de orientação teórica é que a função de um tribunal constitucional tem um caráter político de grau muito maior que a função de outros tribunais - e nunca os defensores da instituição de um tribunal constitucional desconheceram ou negaram o significado eminentemente político das sentenças deste - mas não que por causa disso ele não seja um tribunal, que sua função não seja jurisdicional; e menos ainda: que tal função não possa ser confiada a um órgão dotado de independência judiciária.”
} 
MONTESQUIEU) ${ }^{46}$, ressalta que, nem por isso, deixa de ser ato jurisdicional, sendo que ambas devem possuir caráter político. ${ }^{47} 4849$

Na verdade, o produto do processo de controle de constitucionalidade não é, a rigor, um ato legislativo, mas sim a invalidação de uma lei ou a confirmação de sua constitucionalidade. Portanto, como explicitado por KELSEN, a atividade criativa por parte do tribunal constitucional é exercida em grau muito menor que aquela exercida pelo Poder Legislativo, preponderando em sua atuação a aplicação do texto constitucional. Ademais, nos ordenamentos, como o nosso, que adotam o princípio da nulidade da lei inconstitucional, na qual os efeitos da decisão proferida pelo tribunal retroagem, em regra, à data de edição do ato (Lei federal nº 9.868/99, art. 27; Lei federal ${ }^{\circ}$ 9.882/99, art. 11) ${ }^{50}$, a invalidação não se confunde com a revogação (que é operada por nova

\footnotetext{
${ }^{46}$ No mesmo artigo formulado com vistas a refutar a posição de CARL SCHMITT acerca de quem deva ser o guardião da Constituição, compilada na referida edição em língua portuguesa, KELSEN enfoca, novamente, a questão da atuação do tribunal como legislador negativo: "Do ponto de vista teórico, a diferença entre um tribunal constitucional com competência para cassar leis e um tribunal civil, criminal ou administrativo normal é que, embora sendo ambos aplicadores e produtores do direito, o segundo produz apenas normas individuais, enquanto o primeiro, ao aplicar a Constituição a um suporte fático de produção legislativa, obtendo assim uma anulação da lei inconstitucional, não produz, mas elimina uma norma geral, instituindo assim o actus contrarius correspondente à produção jurídica, ou seja, atuando - como formulei anteriormente - como legislador negativo.” In: KELSEN, Hans. Jurisdição Constitucional. São Paulo, Martins Fontes, 2003, p. 263.

${ }^{47}$ Ibidem, p. 258-259.

${ }^{48}$ KELSEN inicia citando argumento utilizado por SCHMITT: "Não é portanto estranho que Schmitt, depois de haver se servido dessa teoria do automatismo para separar, como princípio, a jurisdição como mera aplicação da lei e a legislação como criação do direito, e depois que ela lhe assegurou o principal argumento teórico em sua luta contra a jurisdição constitucional - 'uma lei não é uma sentença, uma sentença não é uma lei' -, coloque-a de lado, declarando enfaticamente: 'Em toda decisão, mesmo na de um tribunal que resolva um processo mediante a subsunção de um fato material, há um elemento de decisão pura que não pode ser deduzido do conteúdo da lei.' Pois bem, é justamente dessa compreensão que resulta o fato de que entre lei e sentença não existe diferença qualitativa, que esta é, tanto quanto aquela, produção de direito, que a decisão de um tribunal constitucional, por ser um ato de legislação, isto é, de produção do direito, não deixa de ser ato de jurisdição, ou seja, de aplicação do direito, e particularmente que, em função de o elemento decisão não se limitar de modo algum à função legislativa, mas sim também - e necessariamente - estar contido na função judicial, ambas devem possuir caráter político.” In: Ibidem, p. 263.

${ }^{49}$ Sobre a transformação do papel do Poder Judiciário na passagem do Estado liberal para o Estado social, veja-se CAMPILONGO, Celso Fernandes. Política, Sistema Jurídico e Decisão Judicial. São Paulo, Max Limonad, 2002, p. 38-42, no qual o autor esclarece que, do antigo Estado liberal, fundado nas noções de imparcialidade do juiz, não interferência na vida privada do indivíduo por parte do Judiciário e monopólio parlamentar da produção do Direito, passa-se, no século XX, a um Estado que tem forte atuação em amplos segmentos sociais, no qual o Judiciário transforma-se em árbitro de um conflito constitucional, no qual muitas vezes estão envolvidos órgãos do próprio Estado e onde lhe cabe, ao resolver o conflito, dar a última palavra, donde decorrem os temores decorrentes da politização do Direito e judicialização da política.

50 "A norma contida no art. 27 da Lei n. 9.868, de 10 de novembro de 1999, tem caráter fundamentalmente interpretativo, desde que se entenda que os conceitos jurídicos indeterminados utilizados - segurança jurídica e excepcional interesse social - se revestem de base constitucional. No que diz respeito à segurança jurídica, parece
} 
lei), pois esta produz efeitos a partir da publicação da lei que revoga a anterior. Realmente, dispõe a Lei de Introdução ao Código Civil (Decreto-lei no 4.657, de 4 de setembro de 1942), em seu artigo $2^{\circ}$, que: “Não se destinando à vigência temporária, a lei terá vigor até que outra a modifique ou revogue.” E, ainda que a lei disponha expressamente que terá caráter retroativo, não poderá atingir o ato jurídico perfeito, o direito adquirido e a coisa julgada.

Em Atenas, na época de Péricles, a anulação das leis contrárias ao direito superior era feita por uma ação de natureza penal (o graphé paranomón) que a um só tempo destinava-se a punir os autores da lei e anular os seus efeitos (veja-se comentário adiante, em tópico acerca da evolução do controle de constitucionalidade).

Também nesse sentido, KELSEN pondera que a escolha do procedimento por meio do qual um órgão dotado de independência judiciária examinará a constitucionalidade das leis é matéria de política do direito. Neste contexto, deve-se analisar a forma do procedimento e verificar se terá um caráter litigioso, ou seja, "se deve ser formulado de modo que os prós e contras da constitucionalidade sejam discutidos de modo mais publicamente possível”. ${ }^{51}$

Esclarece, ainda, que o método litigioso não é exclusivo do Judiciário, pois o processo administrativo também é assim formulado e lembra que, na antiga Atenas, “durante certo período, até mesmo o processo legislativo tinha essa configuração: quando uma lei antiga devia ser substituída por uma nova, a primeira era acusada diante dos nomótetas". 52

não haver dúvida de que encontra expressão no próprio princípio do Estado de Direito consoante, amplamente aceito pela doutrina pátria e alienígena. Excepcional interesse social pode encontrar fundamento em diversas normas constitucionais. O que importa assinalar é que, consoante a interpretação aqui preconizada, o princípio da nulidade somente há de ser afastado se se puder demonstrar, com base numa ponderação concreta, que a declaração de inconstitucionalidade ortodoxa envolveria o sacrifício da segurança jurídica ou de outro valor constitucional materializável sob a forma de interesse social.” In: AI 474.708-AgR, Rel. Min. Gilmar Mendes, decisão monocrática, julgamento em 17-3-08, DJE de 18-4-08. Não fosse assim, incidiria em flagrante inconstitucionalidade, pois a norma tem sede legal e não constitucional.

${ }^{51}$ KELSEN, Hans. Jurisdição constitucional. São Paulo, Martins Fontes, 2003, p. 264.

${ }^{52}$ Ibidem, p. 264. 
Aduz que este procedimento é conhecido como forma judiciária em virtude de, historicamente, e até hoje, ser utilizado nos tribunais. E arremata que o "caráter litigioso, o assim-chamado caráter judiciário do procedimento, é também totalmente indicado quando se trata da aplicação de uma norma constitucional que concede larga margem de discricionariedade”. ${ }^{53}$ Voltarei a este ponto adiante, ao tratar do princípio do contraditório.

Analisando a jurisdição constitucional alemã, GILMAR FERREIRA MENDES esclarece as diferenças entre a atuação da jurisdição constitucional, condicionada à provocação dos legitimados e impedida de agir de ofício, e a das outras atividades, de cunho exclusivamente político:

“O Bundesverfassungsgericht somente atua mediante provocação. O princípio do pedido é essencial para a jurisdição constitucional, uma vez que dele depende, em determinada medida, a qualificação de órgão decisório como um Tribunal. A forma judicial constitui característica peculiar que permite distinguir a atuação da jurisdição constitucional de outras atividades, de cunho meramente político. Enquanto o Parlamento pode decidir livremente quando determinada matéria será disciplinada por lei, ao Bundesverfassungsgericht é vedado tomar iniciativas próprias." ${ }^{4}$

Sob um prisma que leva em conta elementos processuais, em particular a formação de coisa julgada material a partir da decisão da Corte Constitucional, NELSON NERY JR. e ROSA MARIA ANDRADE NERY asseveram, ao analisar a ação direta de inconstitucionalidade e a ação declaratória de constitucionalidade, que:

"Há atividade jurisdicional do STF no julgamento dessas ações com a conseqüente coisa julgada material sobre essa decisão, ato de império da Corte Constitucional, o que não ocorre com decisões administrativas de órgãos do Poder Judiciário.”55

Também ressaltando os efeitos da decisão proferida em sede de ação direta de inconstitucionalidade, afirma JOSÉ AFONSO DA SILVA ser ela apta a

\footnotetext{
${ }^{53}$ KELSEN, Hans. Jurisdição Constitucional. São Paulo, Martins Fontes, 2003, p. 264-265.

${ }^{54}$ Ibidem, p. 106-107.

55 NERY Jr., Nelson; NERY, Rosa Maria Andrade. Constituição Federal comentada e legislação constitucional. São Paulo, RT, 2006, p. 537.
} 
produzir coisa julgada material ${ }^{56}$, o que leva à inafastável conclusão de que se trata de atividade jurisdicional, pois as demais atividades estatais não se prestam a esta finalidade, sendo a atividade jurisdicional a única apta a produzir coisa julgada material.

Ao tratar dos "problemas metodológicos no âmbito da jurisdição constitucional”, CANOTILHO coloca com solar clareza que o “Tribunal Constitucional é um órgão de jurisdição". 57

A reconhecer o caráter jurisdicional do controle de constitucionalidade por via principal, mas de forma atípica, assevera LUÍS ROBERTO BARROSO que:

\begin{abstract}
“A função jurisdicional, como regra geral, destina-se a solucionar conflitos de interesse, a julgar uma controvérsia entre as partes que possuem pretensões antagônicas. O controle de constitucionalidade por ação direta ou por via principal, conquanto também seja jurisdicional, é um exercício atípico de jurisdição, porque nele não há um litígio ou situação concreta a ser solucionada mediante a aplicação da lei pelo órgão julgador. Seu objeto é o pronunciamento acerca da própria lei." 58
\end{abstract}

Citando o magistério de MARTÍNEZ SOSPEDRA, ANDRÉ RAMOS TAVARES enfeixa argumentos que conferem caráter jurisdicional a um Tribunal Constitucional, quais sejam:

\footnotetext{
56 "Qual a eficácia da sentença proferida no processo da ação direta de inconstitucionalidade genérica? [...] O objeto do julgamento consiste em desfazer os efeitos normativos (efeitos gerais) da lei ou ato -a eficácia da sentença tem exatamente esse efeito, e isto tem valor geral, evidentemente, e vincula a todos. Em suma, e isto tem valor geral, evidentemente, e vincula a todos. Em suma, a sentença, aí, faz coisa julgada material, que vincula as autoridades aplicadoras da lei, que não poderão mais dar-lhe execução sob pena de arrostar a eficácia da coisa julgada, uma vez que a declaração de inconstitucionalidade em tese visa precisamente a atingir o efeito imediato de retirar a aplicabilidade da lei. Se não fosse assim, seria praticamente inútil a previsão constitucional de ação direta de inconstitucionalidade genérica.” In: SILVA, José Afonso da. Curso de direito constitucional positivo. São Paulo, Malheiros, 2004, p. 54-55 (grifos nossos).

${ }^{57}$ CANOTILHO, José Joaquim Gomes. Direito constitucional e teoria da Constituição. $7^{\mathrm{a}}$ ed., Coimbra, Almedina, 2003, p. 1305. Esclarece, outrossim, que isto não impede de a jurisdição desenvolvida pelo Tribunal Constitucional possuir "especificidades metódicas em relação à actividade jurisdicional desenvolvida por outros tribunais", em virtude de decidir questões eminentemente políticas.

${ }^{58}$ BARROSO, Luis Roberto. O controle de constitucionalidade no direito brasileiro. $2^{\mathrm{a}}$ ed., São Paulo, Saraiva, 2006, p. 133-34.
} 
"sua estrutura de organização e funcionamento, que é igual à do Poder Judiciário, e seu raciocínio ajustado ao direito objetivo e ao procedimento estabelecido para o processo judicial. Além deles, o autor elenca, ainda, a independência de que goza o Tribunal Constitucional, em relação aos demais órgãos do Estado., 59

E conclui o ilustre professor, a fazer distinção entre os eventuais efeitos políticos da decisão e o processo para sua tomada, que o processo adotado pelo Tribunal Constitucional “é jurisdicional por excelência”. 60

A processualística moderna, por outro lado, repudia a noção de exercício da jurisdição com o escopo exclusivamente jurídico. Dessa forma, mesmo em casos em que o escopo jurídico do processo é muito tênue, como acontece na jurisdição voluntária, que se caracterizaria como uma administração pública de interesses privados, parte da doutrina (ainda que minoritária) não nega o caráter jurisdicional da prestação estatal. De fato, como esclarece DINAMARCO:

\begin{abstract}
"Na jurisdição voluntária é tênue o escopo jurídico de atuar a vontade do direito, incluído entre as características da jurisdição e do próprio sistema processual, mas isso não basta para desfigurá-la porque o direito moderno dá primazia a outros escopos, notadamente o de solucionar conflitos e pacificar pessoas. A exclusividade do escopo jurídico da jurisdição, própria do período conceitual do direito processual civil mas repudiada na processualística moderna [...], seria no passado uma válida premissa para a negação do caráter jurisdicional à jurisdição voluntária mas hoje não tem mais essa força. Em todos os casos nos quais o juiz é chamado a exercer a jurisdição voluntária existe sempre alguma situação conflituosa e um estado de insatisfação que afligem pessoas e necessita de solução." ${ }^{61}$
\end{abstract}

Assim, podem ser elencados os seguintes elementos, aptos a caracterizar a natureza jurisdicional da atividade exercida pelos tribunais constitucionais: a) a diferença entre a anulação da lei, que se realiza como mera atividade de aplicação das normas da Constituição e a atividade legislativa propriamente dita, na qual há plena liberdade de conformação do direito (tendo como limites apenas a Constituição); b) a forma de acesso ao

\footnotetext{
${ }^{59}$ TAVARES, André Ramos. Tribunal e jurisdição constitucional. São Paulo, Celso Bastos Editor, 1998, p. 44.

${ }^{60}$ Ibidem, p. 47.

${ }^{61}$ DINAMARCO, Cândido Rangel. Instituições de direito processual civil, v. I. $6^{a}$ ed., São Paulo, Malheiros, 2009, p. 326.
} 
tribunal, que, no Brasil, não é realizado por eleição, mas por indicação do Presidente da República e sabatina do Senado Federal, segundo critério meritocrático ${ }^{62}$; c) a inércia de sua atividade $^{63}$; d) o rol de legitimados a dar início ao processo de controle abstrato, que congrega agentes políticos, órgãos públicos e entidades de natureza privada, essencialmente diverso dos legitimados a iniciar o processo legislativo; e) os efeitos que produz a decisão de inconstitucionalidade, que não se confundem com a revogação de uma lei, pois esta possui, em regra, efeitos para o futuro (ex nunc) e deve resguardar o ato jurídico perfeito, o direito adquirido e a coisa julgada, enquanto a decisão no controle de constitucionalidade possui, normalmente, efeitos que eliminam a lei desde o seu nascedouro (ex tunc) ${ }^{64}$; e f) por fim, a jurisdicionalidade do procedimento adotado para a tomada da decisão.

Portanto, há de se concluir que a atividade de controle abstrato de constitucionalidade, vista sob o ponto de vista do processo pelo qual se realiza, tem um caráter essencialmente jurisdicional. O processo e procedimento pelos quais se alcança a decisão possuem elementos que o caracterizam inegavelmente como exercício da função jurisdicional. A decisão proferida a final, por sua vez, tem caracteres tanto de ato jurisdicional

${ }^{62}$ A forma de composição do Supremo Tribunal Federal é prevista no art. 101 da Constituição Federal: “O Supremo Tribunal Federal compõe-se de onze Ministros, escolhidos dentre cidadãos com mais de trinta e cinco e menos de sessenta e cinco anos de idade, de notável saber jurídico e ilibada reputação.” (grifo nosso).

${ }^{63}$ Quando a Constituição Federal dispõe que podem propor a ação direta de inconstitucionalidade (art. 103), está restringindo o início da atividade jurisdicional à provocação dos legitimados (princípio da ação ou demanda, vide item 3.2.3, infra).

${ }^{64}$ No Brasil é inegável que a decisão proferida em sede de controle concentro, em regra, atinge a validade da lei ou ato normativo desde o seu nascedouro. De fato, a modulação dos efeitos requer sejam preenchidos os requisitos previstos no art. 27 da Lei federal $\mathrm{n}^{\circ}$ 9.868/99, com o seguinte teor: “Ao declarar a inconstitucionalidade de lei ou ato normativo, e tendo em vista razões de segurança jurídica ou de excepcional interesse social, poderá o Supremo Tribunal Federal, por maioria de dois terços de seus membros, restringir os efeitos daquela declaração ou decidir que só tenha a partir de seu trânsito em julgado ou de outro momento a ser fixado.” Em relação à arguição de descumprimento de preceito fundamental, há dispositivo semelhante (Lei federal $\mathrm{n}^{\circ}$ 9.882/99). Vigora, portanto, entre nós, o princípio da nulidade do ato inconstitucional, que pode ser afastado apenas nas condições acima mencionadas.

${ }^{65}$ É esse o entendimento do Supremo Tribunal Federal: "EMBARGOS DECLARATÓRIOS - OMISSÃO FIXAÇÃO DO TERMO INICIAL DOS EFEITOS DA DECLARAÇÃO DE INCONSTITUCIONALIDADE RETROATIVIDADE TOTAL. Inexistindo pleito de fixação de termo inicial diverso, não se pode alegar omissão relativamente ao acórdão por meio do qual se concluiu pelo conflito do ato normativo autônomo abstrato com a Carta da República, fulminando-o desde a vigência. MUNICÍPIOS - PARTICIPAÇÃO NA ARRECADAÇÃO DO IMPOSTO SOBRE CIRCULAÇÃO DE MERCADORIAS E SERVIÇOS - INCONSTITUCIONALIDADE DE LEI ESTADUAL - ALCANCE DA DECLARAÇÃO. A ofensa frontal da lei do Estado à Constituição Federal implicou, no julgamento ocorrido, o afastamento retroativo à data do surgimento de eficácia do ato impugnado.” In: ADI 2728 ED/AM-AMAZONAS. Relator: Min. MARCO AURÉLIO. Julgamento: 19/10/2006. Órgão Julgador: Tribunal Pleno. Publicação: DJe-117 DIVULG 04-10-2007 PUBLIC 05-10-2007. DJ 05-102007, p. 021. Ement. Vol. 02292-01, p. 074, RTJ VOL-00202-02, p. 0516. 
(aplicação da Constituição com vistas a decidir o conflito entre normas, formação de coisa julgada material) como pode ter características, como sustenta a doutrina kelseniana, de ato legislativo (semelhante à revogação da lei, mas com as peculiaridades acima expostas), quando declarada a inconstitucionalidade (por isso a afirmação de KELSEN de que a função exercida pelo tribunal constitucional seria legislativa). Ressalte-se, todavia, que a decisão que não reconhece a inconstitucionalidade e a que declara a constitucionalidade da lei, não possuem essa natureza semelhante à do ato legislativo.

Quanto ao processo e procedimentos mais adequados ao exercício da atividade de controle abstrato de constitucionalidade, entendo que sejam os judicialiformes. Os processos judicialiformes são usuais no âmbito das instâncias judiciais, iluminados pelos princípios do processo, hauridos muitas vezes através de séculos de experiência - o devido processo legal, como se sabe, tem sua origem na Magna Carta, de 1215 -, muitos deles previstos em sede constitucional e, por isso, necessariamente aplicáveis a toda a espécie de processo, guardadas, indiscutivelmente, as peculiaridades do controle abstrato de normas, que exigirão regras e soluções específicas, em casos determinados.

\subsection{Processo e procedimento constitucionais}

\subsubsection{Caracterização e crescente relevância do processo constitucional}

O processo e o procedimento têm ganhado uma especial relevância no direito público contemporâneo, revelados como instrumentos voltados a conferir legitimidade às decisões tomadas pelo Estado.

Em seu ensaio sobre $O$ futuro da democracia, BOBBIO identifica um conteúdo mínimo para que uma decisão a ser tomada possa ser aceita como 
decisão coletiva, consubstanciado na delimitação dos legitimados a tomá-las e no procedimento apto a alcançá-la. ${ }^{66}$

\author{
A ligação umbilical entre os direitos fundamentais e o \\ procedimento é ressaltada por CANOTILHO:
}

\begin{abstract}
“Qualquer que seja a ‘ética processual' subjacente ao acolhimento do direito ao procedimento no âmbito dos direitos fundamentais, poderemos partir, pragmaticamente, da relevância da dimensão procedimental, se colocarmos o problema nos termos seguintes:

1 - O procedimento é um sistema de regras e/ou princípios;

2 - Essas regras e princípios visam a obtenção de um resultado determinado;

3 - A justa conformação do procedimento, no âmbito dos direitos fundamentais permite, pelo menos, a presunção de que o resultado obtido através da observância do iter procedimental é, com razoável probabilidade e em medida suficiente, adequado aos direitos fundamentais;

4 - O direito ao procedimento implica, fundamentalmente: (1) direito à criação, pelo legislador, de determinadas normas procedimentais ou processuais; (2) direito à interpretação e à aplicação concreta, pelo juiz, das normas e princípios procedimentais ou processuais.

Deste esquema resultam já os contornos da questão essencial. Sendo certo que, de acordo com a tese de GOERLICH, qualquer direito fundamental pressupõe um suporte procedimental/processual, será legítimo afirmar a existência de um dever do legislador e de um correspondente direito do titular do direito fundamental, quanto à criação e ordenação adequada do procedimento ou processo indispensável à garantia do direito material? Por outras palavras: a proteção através do procedimento ou processo significa direito fundamental ao procedimento?’67
\end{abstract}

Não só o procedimento jurisdicional tem ganhado relevo como também outras espécies de procedimentos como o procedimento legislativo, voltado à discussão e aprovação de projeto de lei ou de outras espécies normativas, e o procedimento

\footnotetext{
66 "Afirmo preliminarmente que o único modo de se chegar a um acordo quando se fala de democracia, entendida como contraproposta a todas as formas de governo autocrático, é o de considerá-la caracterizada por um conjunto de regras (primárias e fundamentais) que estabelecem quem está autorizado a tomar as decisões coletivas e com quais procedimentos. Todo grupo social está obrigado a tomar decisões vinculatórias para todos os seus membros com o objetivo de prover a própria sobrevivência, tanto interna como externamente. Mas até as decisões de um grupo são tomadas por indivíduos (o grupo como tal não decide). Por isto, para que uma decisão tomada por indivíduos (um, poucos, muitos, todos) possa ser aceita como decisão coletiva é preciso que seja tomada com base em regras (não importa se escritas ou consuetudinárias) que estabeleçam quais são os indivíduos autorizados a tomar as decisões vinculatórias para todos os membros do grupo, e à base de quais procedimentos." In: BOBBIO, Norberto. O Futuro da Democracia. 10a ed., São Paulo, 2006, p. 30-31.

${ }^{67}$ CANOTILHO, José Joaquim Gomes. Estudos sobre Direitos Fundamentais. $1^{\mathrm{a}}$ ed. brasileira, $2^{\mathrm{a}}$ ed. portuguesa, São Paulo, Coimbra Editora e Revista dos Tribunais, 2008, p. 75-76.
} 
administrativo, destinado a por em funcionamento a burocracia administrativa, com vistas a alcançar os fins e objetivos da administração pública, mediante regras que garantam a oportunidade de manifestação, a participação do particular interessado, a publicidade, instâncias recursais etc.

LUIZ GUILHERME MARINONI afirma estarem enganados aqueles que amesquinham a importância do procedimento entendendo que este seria "um resquício de uma época em que o processo era somente um rito para a aplicação judicial do direito material [...]”, pois o “procedimento, em abstrato - como lei ou módulo legal - ou no plano dinâmico - como seqüência de atos -, tem evidente compromisso com os fins da jurisdição e com os direitos dos cidadãos”. ${ }^{6}$

LUHMANN, igualmente, identifica no procedimento juridicamente regulado um importante elemento de legitimação da atuação do poder. ${ }^{69}$

O procedimento, sob a perspectiva da doutrina processual, pode ser visto como um conjunto de atos encadeados que se voltam à produção de um ato final, a decisão ou sentença. O processo seria mais que isto, envolveria, além do procedimento, também as relações entre os sujeitos do processo (o juiz, sujeito imparcial, e as partes). ${ }^{70}$

O processo constituir-se-ia, portanto, pela soma da relação jurídica processual - relação entre os sujeitos do processo - e o procedimento.

\footnotetext{
${ }^{68}$ MARINONI, Luiz Guilherme. Teoria Geral do Processo. $3^{\text {a }}$ ed., São Paulo, RT, 2008, p. 401.

${ }^{69}$ LUHMANN, Niklas. Legitimação pelo Procedimento. Brasília, Editora Universidade de Brasília, 1980, p. 29-35.

${ }^{70}$ ARAÚJO CINTRA, Antonio Carlos de; GRINOVER, Ada Pellegrini; DINAMARCO, Cândido Rangel, esclarecem que: "Etimologicamente, processo significa 'marcha adiante', 'caminhada' (do latim, procedere = seguir adiante). Por isso, durante muito tempo foi ele confundido com a simples sucessão de atos processuais (procedimento), sendo comuns as definições que o colocavam nesse plano. Contudo, desde 1868, com a obra de Bülow (Teoria dos pressupostos processuais e das exceções dilatórias), apercebeu-se a doutrina de que há, no processo, uma força que motiva e justifica a prática dos atos do procedimento, interligando os sujeitos processuais. O processo, então, pode ser encarado pelo aspecto dos atos que lhe dão corpo e das relações entre eles, e igualmente pelo aspecto das relações entre os seus sujeitos.” In: Teoria Geral do Processo. $25^{a}$ ed., São Paulo, Malheiros, 2009, p. 297.
} 
Para alguns, quando não há o exercício da jurisdição -entendida como a substituição da vontade das partes pela decisão jurisdicional -, não se estaria propriamente diante de um processo, mas sim de mero procedimento. Dessa forma, não se caracterizariam como processos os procedimentos de jurisdição voluntária, o procedimento administrativo, e o legislativo (visão também sujeita a críticas, como já se viu acima).

MARCUS ORIONE GONÇALVES CORREIA esclarece que se deve tomar "a relação jurídico-processual como 'alma' do processo, e o procedimento como ‘corpo' deste”. ${ }^{71} \mathrm{O}$ procedimento seria o meio extrínseco do processo, a maneira pela qual ele se desenvolve, sua manifestação fenomênica perceptível.

DINAMARCO coloca no contraditório o elemento qualificador do processo enquanto tal, de modo a diferenciar-lhe do procedimento: "hoje facilmente se compreende que todo poder se exerce mediante um procedimento, caracterizando-se este como processo desde que seja feito em contraditório". ${ }^{72}$

Em sede de controle de constitucionalidade, o processo é de suma importância para que se alcance a efetiva proteção das normas constitucionais, bem como a legitimidade da decisão proferida pelo órgão encarregado de resguardá-las e, diante da natureza da atribuição exercida pelo tribunal constitucional, reveste-se de caráter especialíssimo.

É necessário ter a noção de que todo processo se desenvolve por meio de um procedimento e que este deve fornecer os instrumentos hábeis a alcançar a tutela jurisdicional específica às diversas espécies processuais. A técnica processual destina-se a

\footnotetext{
${ }^{71}$ CORREIA, Marcus Orione Gonçalves. Direito Processual Constitucional. São Paulo, Saraiva, 2002, p. 01. Esclarece, ainda, o autor: "Assim, a relação estabelecida entre juiz e partes, em torno de direitos e obrigações processuais, atados por um vínculo então estabelecido, sintetiza a própria essência da noção da relação jurídicoprocessual. Já a exteriorização dessa relação, através de atos interligados e tendentes a um fim - a sentença -, concretiza a noção de procedimento (outro componente da concepção jurídica do processo). No entanto, como ocorre com a noção de ação, há ainda um conteúdo político da idéia de processo, a que nos reportaremos no momento oportuno.” In: CORREIA, Marcus Orione Gonçalves. Direito Processual Constitucional. São Paulo, Saraiva, 2002, p. 01.

${ }^{72}$ DINAMARCO, Cândido Rangel. A instrumentalidade do processo. $13^{\mathrm{a}}$ ed, São Paulo, Malheiros, p. 149.
} 
conferir efetividade à aplicação das normas de direito material; no caso do processo de controle principal, às normas da própria Constituição.

\subsubsection{O Direito Processual Constitucional}

Diante da especificidade do processo de controle abstrato de constitucionalidade, cogita-se da configuração do Direito Processual Constitucional como ramo autônomo do Direito processual.

Inicialmente, é necessário esclarecer que o questionamento poderia ser feito apenas no que diz respeito ao controle abstrato de constitucionalidade, que pode ser visto como a jurisdição constitucional em sentido estrito. De fato, o controle concreto ou incidental, como se sabe, é realizado em um processo comum, entre partes, motivo pelo qual deve seguir as regras do processo que regem a matéria. Não se trata, no controle concreto, de processo constitucional, mas, sim, de processo comum, ressalva feita apenas ao incidente de inconstitucionalidade de efeitos gerais nos ordenamentos jurídicos que o preveem.

CANOTILHO define o direito processual constitucional como “o conjunto de regras e princípios positivados na Constituição e noutras fontes de direito (leis e tratados) que regulam os procedimentos juridicamente ordenados à solução de questões de natureza jurídico-constitucional pelo Tribunal Constitucional”. ${ }^{73}$

Há controvérsia na doutrina nacional e estrangeira acerca da questão de o Direito Processual Constitucional configurar ramo cientificamente apartado do processo comum.

${ }^{73}$ CANOTILHO, Joaquim José Gomes. Direito constitucional e teoria da Constituição. $7^{\mathrm{a}}$ ed., Coimbra, Almedina, 2003, p. 965. 
A entender que se trata de um corte metodológico apto a melhor estudar as especificidades do processo constitucional, em particular do controle abstrato de constitucionalidade, ARAÚJO CINTRA, GRINOVER e DINAMARCO defendem que:

“A condensação metodológica e sistemática dos princípios constitucionais do processo toma o nome de direito processual constitucional.

Não se trata de um ramo autônomo do direito processual, mas de uma colocação científica, de um ponto-de-vista metodológico e sistemático, do qual se pode examinar o processo em suas relações com a Constituição.,"74

Todavia, a questão fica mais intrincada se considerarmos apenas a jurisdição constitucional em sentido estrito, ou seja, o controle abstrato de constitucionalidade.

A jurisdição constitucional em sentido estrito possui regras próprias, fundadas em princípios específicos, que a caracterizam como um processo diferenciado em relação aos demais. A relação jurídica processual no controle abstrato de constitucionalidade é peculiar, pois nela se coloca em cheque a existência de partes, na medida em que não há defesa de interesses pessoais (ao menos diretamente) e sim da ordem jurídica constitucional, o que leva o processo a assumir a característica de processo objetivo.

Nesse contexto, o procedimento apto a regular o desenvolvimento de uma relação processual sui generis é especialíssimo, guardando nítidas características próprias, que o distinguem claramente dos demais.

CELSO DE MELLO, ao relatar acórdão que indeferiu a intervenção, como terceiro interessado, de entidade de cunho privado em ação direta de inconstitucionalidade $^{75}$, defende a autonomia instrumental do processo constitucional, demonstrando não ser possível a aplicação em seu âmbito da generalidade das normas

\footnotetext{
${ }^{74}$ ARAÚJO CINTRA, Antonio Carlos; GRINOVER, Ada Pellegrini; DINAMARCO, Cândido Rangel. Teoria Geral do Processo. 25 ed., São Paulo, Malheiros, 2009, p. 85.

75 Observe-se que, à época do julgamento, não havia a previsão legal referente ao amicus curiae, inserida, posteriormente, na Lei $n^{\circ} 9.868 / 99$, art. $7^{\circ}$, $2^{\circ}$ e na Lei $n^{\circ} 9.882 / 99$, art. $6^{\circ}, \S 2^{\circ}$.
} 
aplicáveis ao processo comum, impedindo, assim, a aplicação ordinária do princípio da subsidiariedade ao processo de controle abstrato de normas. Em suas palavras:

\begin{abstract}
"em regra, não se deve reconhecer, como pauta usual de comportamento hermenêutico, a possibilidade de aplicação sistemática, em caráter supletivo, das normas concernentes aos processos de índole subjetiva, especialmente daquelas meramente legais que disciplinam a intervenção de terceiros na relação processual”. ${ }^{76} 77$
\end{abstract}

\title{
VITALINO CANAS defende a completa autonomia do Direito
}

Processual Constitucional:

"De tudo o que escrevemos nas páginas anteriores só se pode extrair uma conclusão: o direito processual constitucional não pode deixar de ser um direito processual autónomo, regido por princípios próprios, necessariamente pouco fungíveis com os dos processos jurisdicionais típicos." 78

É preciso ter em mente, todavia, que o ramo processual autônomo que CANAS vislumbra é algo bastante abrangente, a incluir no Direito Processual Constitucional até mesmo processos não jurisdicionais. De fato, segundo a visão de CANAS acerca do processo constitucional, este abarcaria não só as garantias processuais da Constituição, como também outros processos materialmente constitucionais, como o processo legislativo, o processo de revisão constitucional, o processo de declaração de estado de sítio, de estado de emergência etc. ${ }^{79}$ Tal concepção me parece demasiadamente extensa, não encontrando ressonância seja no ordenamento jurídico seja na doutrina nacionais.

\footnotetext{
${ }^{76}$ ADI-AgR 1254-1 RJ, j. 14/08/1996, grifos no original.

77 Em outra oportunidade, o Ministro CELSO DE MELLO, em voto proferido na ação direta de inconstitucionalidade $\mathrm{n}^{0} 2.995$ AgR/PE, julgada em 31/10/2006, chegou a fazer menção a uma absoluta autonomia do processo de fiscalização abstrata de constitucionalidade em relação aos institutos e normas dos processos de índole subjetiva: "Não se pode deixar de reconhecer, por isso mesmo, no plano do controle normativo abstrato de constitucionalidade, a absoluta autonomia que o processo de fiscalização concentrada ostenta, ordinariamente, em relação aos institutos e normas peculiares aos processos de índole meramente subjetiva."

${ }^{78}$ CANAS, Vitalino. Os processos de fiscalização da constitucionalidade e da legalidade pelo Tribunal Constitucional: Natureza e princípios estruturantes. Coimbra, Coimbra Editora, 1986, p. 87-88.

${ }^{79}$ Ibidem, p. 13 e 14. Veja-se também a definição que CANAS confere ao Direito Processual Constitucional, a confirmar a amplitude de seu conceito: "Nestes termos propenderíamos para uma noção mais ampla de direito processual constitucional e defini-lo-íamos como o conjunto de normas que regulam os actos e princípios de natureza processual orientados à produção de um acto constitucional (final), entendido este como o acto
} 
JULIANO TAVEIRA BERNARDES ressalta que a jurisdição constitucional brasileira, entendida como o controle de constitucionalidade em geral, não poderia ser tida como ramo autônomo do Direito Processual Constitucional geral, pois "em quaisquer processos podem surgir questões constitucionais e [...] o sistema difuso de controle de constitucionalidade permite a todo juiz decidi-las sem a necessidade de instauração de nova relação processual [...]”. ${ }^{80}$ Pondera, todavia, que não ocorre o mesmo se forem considerados apenas os processos de jurisdição constitucional em sentido estrito, pois, nestes, o "elevado número de peculiaridades permitem concluir: o processo constitucional (também entendido aqui em sentido estrito) goza de autonomia científica”, ${ }^{81}$

ANDRÉ RAMOS TAVARES reconhece a controvérsia, citando as posições de HÄBERLE, pela autonomia, e de FRÖHLINGER, pela aplicação das regras gerais do processo para o campo constitucional, concluindo que:

“Não obstante a corrente a que cada um se filie, parece inegável que há uma especificidade, que faz o Direito Processual Constitucional depender de uma série de regras autônomas em relação ao processo em geral e que, em boa parte, chegam até a negar as regras gerais do processo, tal como a de que em todo processo há uma triangulação entre autor-réu-juiz.”,82

Em outra oportunidade, ao comentar o processo da arguição de descumprimento de preceito fundamental, TAVARES observa que se trata de um processo de natureza objetiva, não se podendo pretender fazer "o uso dos mesmos princípios constitucionais do processo comum ou das regras utilizadas para o processo ordinário. Aquele primeiro não é e não pode ser regido pelas mesmas regras deste último”, ${ }^{83}$

\footnotetext{
jurídico sujeito e regulado, integralmente ou não, pela Constituição quer no seu conteúdo, quer na sua formação.” In: Ibidem, p. 14, grifos no original.

${ }^{80}$ BERNARDES, Juliano Taveira. Controle abstrato de constitucionalidade: Elementos materiais e princípios processuais. São Paulo, Saraiva, 2004, p. 278.

${ }^{81}$ Ibidem, p. 279.

${ }^{82}$ TAVARES, André Ramos. Tratado da arguição de descumprimento de preceito fundamental. São Paulo, Saraiva, 2001, p. 267 e 268.

${ }^{83}$ Ibidem, p. 305.
} 
Pondera, todavia, que, embora não se possa fazer uma aplicação plena das regras processuais comuns, seria "possível fazer uso de certas categorias processais, com algumas mudanças, como tem assinalado a própria jurisprudência do Supremo Tribunal Federal. Pode-se falar, assim, em elementos e condições da ação, embora com certas reservas". ${ }^{84}$

O Ministro CELSO DE MELLO ressaltou não se mostrar impossível a aplicação das normas concernentes aos processos de índole subjetiva ao controle abstrato de normas, legitimando-se, ainda que em caráter excepcional, a invocação do princípio da subsidiariedade:

"Embora o processo de fiscalização abstrata de constitucionalidade ostente inquestionável perfil objetivo (CLÈMERSON MERLIN CLÈVE, 'A Fiscalização Abstrata da Constitucionalidade no Direito Brasileiro', p. 141/145, item n. 3.2.2, $2^{\mathrm{a}}$ ed., 2000, RT; GILMAR FERREIRA MENDES, 'Jurisdição Constitucional', p. 129/130, $2^{\text {a }}$ ed., 1998, Saraiva; NAGIB SLAIBI FILHO, 'Ação Declaratória de Constitucionalidade’, p. 106, 2ª ed., 1995, Forense) - entendimento este que encontra apoio na própria jurisprudência do Supremo Tribunal Federal (RTJ 113/22 - RTJ 131/1001 RTJ 136/467 - RTJ 164/506-507) -, não se mostra de todo impossível a aplicação, a essa categoria especial de causa, das normas concernentes aos processos de índole subjetiva (ADI 459/SC, Rel. Min. CELSO DE MELLO), legitimando-se, em conseqüência, ainda que em caráter excepcional, a invocação do princípio da subsidiariedade. Daí a advertência do magistério doutrinário, segundo o qual os princípios inerentes ao processo subjetivo somente devem ser aplicados ao processo objetivo desde que observada 'apurada dose de cautela' (CLÈMERSON MERLIN CLÈVE, 'A Fiscalização Abstrata da Constitucionalidade no Direito Brasileiro’, p. 144/145, item n. 3.2.2, 2ª ed., 2000, RT). Desse modo, e sob tal perspectiva, o postulado da subsidiariedade - embora não encontre vigência irrestrita no âmbito do processo objetivo de fiscalização abstrata (ADI 1.350/RO, Rel. Min. CELSO DE MELLO) legitima a aplicação, às ações diretas de inconstitucionalidade, das diretrizes que regem as situações pertinentes ao reconhecimento da legitimidade ativa ad causam para a válida instauração, e para o seu regular prosseguimento, do processo de controle normativo abstrato.” 85

\footnotetext{
${ }^{84}$ TAVARES, André Ramos. Tratado da arguição de descumprimento de preceito fundamental. São Paulo, Saraiva, 2001, p. 307.

${ }^{85}$ ADI n ${ }^{\circ}$ 1063, Relator Ministro CELSO DE MELLO, decisão monocrática, D. J. No 140, do dia 08/08/2001 (grifos nossos).
} 
Note-se, outrossim, que a doutrina processual moderna vê uma tendência unificadora quanto ao tratamento científico da doutrina processual, pelo qual se busca encontrar os pontos comuns na atividade jurisdicional. VICENTE GRECCO FILHO pondera que:

"Modernamente a ciência processual tem recebido uma inspiração unificadora. Após séculos de tratamento distinto, o direito processual civil e o direito processual penal passaram a receber tratamento científico unificado em seus institutos fundamentais, por meio da busca dos pontos comuns da atividade jurisdicional. Igual aproximação receberam o chamado direito processual do trabalho e os ramos especiais do direito processual, ou seja, o direito processual penal militar e o direito processual eleitoral.

A compreensão unitária do direito processual resultou, especialmente, da verificação de que o poder jurisdicional, como um dos poderes do Estado, é único, e sua estruturação básica encontra-se no nível da Constituição Federal, de modo que resulta inevitável a conclusão que há algo em comum na atividade jurisdicional., 86

NELSON NERY JUNIOR, lembrando que o Direito Processual é um sistema uniforme e uno, esclarece que a distinção entre ramos é feita com finalidades didáticas, não se tratando de novos ramos do Direito Processual. ${ }^{87}$

Entendo que o processo do controle abstrato de constitucionalidade é veiculado por um procedimento de inegável especificidade. Todavia, não vejo que, como processo jurisdicional que é, possa ficar completamente imune aos princípios processuais, sobretudo aqueles previstos na própria Constituição. De fato, também são processos especiais aqueles que veiculam o mandado de segurança, o habeas corpus, a ação popular, as ações de impugnação de mandato parlamentar, dentre outros. Embora se sujeitem a regras e princípios próprios - o princípio da verdade real, por exemplo, vigente no processo penal, não se aplica aos demais -, isso não parece suficiente para que o seu estudo seja feito de

\footnotetext{
${ }^{86}$ GRECCO FILHO, Vicente. Direito processual civil brasileiro, v. 1. $20^{a}$ ed., São Paulo, Saraiva, 2008, p. 3.

87 "Naturalmente, o direito processual se compõe de um sistema uniforme, que lhe dá homogeneidade, de sorte a facilitar sua compreensão e aplicação para a solução das ameaças e lesões a direito. Mesmo que se reconheça essa unidade processual, é comum dizer-se didaticamente que existe um direito constitucional processual, para significar o conjunto das normas de direito processual que se encontra na Constituição Federal, ao lado de um direito processual constitucional, que seria a reunião dos princípios para o fim de regular a denominada jurisdição constitucional. Não se trata, portanto, de ramos novos do direito processual.” In: NERY Jr., Nelson. Princípios do processo civil na Constituição Federal. $9^{a}$ ed., São Paulo, Revista dos Tribunais, 2009, p. 41 (grifo nosso).
} 
maneira absolutamente apartada das demais espécies processuais. Essencialmente, todos são processos que adotam a forma judiciária - tal qual sugerido por $\operatorname{KELSEN}^{88}$ - e, assim, respeitadas as especificidades de cada um deles, podem se valer dos princípios gerais de processo que iluminam a matéria, de modo a permitir o seu bom desenvolvimento com base em regras hauridas pela experiência secular.

Portanto, não vejo o Direito Processual Constitucional como disciplina autônoma do Direito Processual, mas apenas, tal qual sugerido por ARAÚJO CINTRA, DINAMARCO e GRINOVER ${ }^{89}$, um corte metodológico para melhor analisar o controle abstrato de normas e suas especificidades.

Indubitavelmente, por outro lado, as regras do processo comum não incidem, via de regra, diretamente ao processo de controle abstrato de constitucionalidade. Mesmo em relação aos princípios processuais, deve haver extrema cautela em sua aplicação ao processo de controle abstrato, pois a natureza especialíssima deste pode afastar, em determinadas situações, a incidência dos princípios gerais ou implicar na necessidade de amoldá-los às suas peculiaridades ou, ainda, exigir a identificação de princípios próprios desta espécie de processo.

\subsection{A evolução do controle de constitucionalidade}

Com vistas a melhor compreender as peculiaridades do controle abstrato de constitucionalidade, bem como dos princípios processuais que o iluminam, é conveniente traçar um breve retrospecto histórico acerca da evolução do controle, bem como da diferenciação dos dois principais sistemas de controle repressivo existentes.

\footnotetext{
${ }^{88}$ KELSEN, Hans. Jurisdição Constitucional. São Paulo, Martins Fontes, 2003, p. 264-265.

${ }^{89}$ Vide nota $\mathrm{n}^{\circ} 74$, supra.
} 


\subsubsection{Introdução}

Alguns vislumbram um remoto antecedente histórico do controle de constitucionalidade no graphé paranomón grega.

Segundo FERREIRA FILHO, já se encontraria na Antiguidade:

“a noção que existe uma diferença entre as leis que estruturam a organização política, fixam a organização do governo, e as demais leis, que são criadas pelos órgãos de governo, vale dizer, a distinção entre leis constitucionais e o que, modernamente, denominaríamos de leis ordinárias". ${ }^{90}$

Dessa forma, pondera, por meio do graphé paranomón poderse-ia impugnar a criação de leis que contradissessem aquelas normas tidas por fundamentais, concernentes à estrutura da polis grega. ${ }^{91}$

\section{RONALDO POLETTI, citando GUSTAVE GLOTZ (La Cité} Grecque, Paris, Albin Michel, 1968) traz interessante histórico desse instrumento, criado à época de Péricles com vistas a conter os arroubos da Ecclésia - os excessos dos demagogos, reunidos em assembleia -, que poderiam levar a soberania popular a se transformar em poder arbitrário. $^{92}$

\footnotetext{
${ }^{90}$ FERREIRA FILHO, Manoel Gonçalves. O Poder Constituinte. São Paulo, Saraiva, $5^{\mathrm{a}}$ ed., 2007, p. 3.

${ }^{91}$ Ibidem, p. 4.

92 "A democracia deve ter por fundamento o respeito à lei. Na verdade, o graphé paranomón era instituto judiciário de natureza criminal, de uma sabedoria precoce, que procurava conter a onipotência da Ecclésia nos seus exatos limites. Nisso, sem dúvida, a rima com o controle de constitucionalidade das leis, as quais tudo podem, menos contrariar a Lei Fundamental.

Antes, as leis dadas pelos deuses eram protegidas pelo poder sagrado da imprecação. Quando as leis foram escritas tiveram por guarda o mais augusto dos tribunais, o Areópago, aquele que tinha atribuições essencialmente religiosas. Com a reforma mencionada de Efialtes, os Areopagistas foram despojados das funções de guarda da Constituição. Foi preciso criar freios à própria democracia, dentro dela mesma. Já que inexistiam controles a ela exteriores.” In: POLETTI, Ronaldo. Controle da constitucionalidade das leis. $2^{\text {a }}$ ed. Rio de Janeiro, Forense, 2000, p. 10.
} 


\section{MAURO CAPPELLETTI também faz uma correlação entre o}

antigo graphé paranomón e a ação direta de inconstitucionalidade, explicando que embora o pséfisma, que se assemelharia à nossa lei ordinária, pudesse ter por conteúdo os mais variados objetos - podia ter regras e normas abstratas e gerais, suscetíveis de se impor de maneira vinculante a todos os cidadãos -, qualquer que fosse este conteúdo, deveria coadunar-se com os nomói tanto em sua forma, quanto em sua substância. ${ }^{93}$

Esclarece, outrossim, o ilustre mestre italiano, que a consequência da ilegalidade de um pséfisma era dúplice: por um lado acarretava a responsabilidade penal para aquele que havia proposto o decreto, por meio de uma ação pública de ilegalidade, justamente o graphé paranomón (que deveria ser proposto no prazo de um ano); e, ainda, a invalidade do decreto contrário à lei, "por força do princípio que se encontra afirmado em um trecho de Demóstenes, segundo o qual o nómos, quando estava em contraste com um pséfisma, prevalecia sobre este". 94 95

\footnotetext{
${ }^{93}$ Como esclarece CAPPELLETTI, o pséfisma deveria, “como seríamos tentados a dizer, nós, juristas modernos, ser constitucional, ou seja não poderia estar em contraste com os nomói vigentes - com as leis constitucionais vigentes”. In: CAPPELLETTI, Mauro. O Controle Judicial de Constitucionalidade das Leis no Direito Comparado. Rio Grande de Sul, Sérgio Fabris Editor, 1999, p. 50.

${ }^{94}$ Ibidem, p. 50 e 51 (grifo nosso).

${ }^{95}$ Sobre a forma por meio da qual se realizava a anulação das psephismas, veja-se PENTEADO, Luiz Carlos de Barros. Democracia em cinco tempos: a luta contra a ágora. 2005, 257 f., dissertação (mestrado em Ciência Política), Instituto de Filosofia e Ciências Sociais, Universidade Federal do Rio de Janeiro, Rio de Janeiro, 2005, na qual invoca as lições de WILSON ACCIOLI: "Um elemento pedagógico também foi agregado pelos gregos à sua concepção da lei: segundo Jaeger, a lei é também uma introdução à filosofia, na medida em que, entre os gregos, a sua criação era obra de uma personalidade superior. As leis verdadeiras deveriam ser capazes de persuadir seus destinatários. O legislador passava também a ser visto como um educador do seu povo, muitas vezes ombreado ao poeta; às máximas da sabedoria poética, juntar-se-iam as determinações da lei - ambas as atividades eram estritamente afins. Esse aspecto se soma à isonomia global dos cidadãos sob as leis, para conformar uma noção da política como uma atividade formacional coletiva, e que nesse sentido também supria um contentamento coletivo através das leis. Dentro dessa concepção, o comando de um tirano, imposto pela força, não seria lei. Essas nomoi ou leis estavam sujeitas a mudanças somente através de revisão anual, pelos cidadãos reunidos em assembléia, na Ekklesia, a Assembléia Geral de todos os cidadãos, a qual tinha o poder de decisão definitiva nos negócios públicos, como nos informa Accioli, influindo inclusive nos aspectos legislativos. Havia ainda os Nomothetai, os quais, como esclarece Mossé, eram magistrados designados, a princípio excepcionalmente, para proceder à revisão das leis, tendo o conselho de nomothetas, a partir do século IV a.C, se tornado permanente. Eram então discutidas as propostas de revalidação de velhas nomoi ou a adoção de novas, editando os nomothetas, ao final, regulação a favor de novas ou velhas leis. Tal procedimento, como acentua Wormuth, sugere uma convenção de natureza constitucional, com as nomoi sendo comparáveis, nesse contexto, as regulações constitucionais e os psephismata à legislação estatutária. Um psephisma era proposto pela Boulé ou Conselho dos Quinhentos; e era aprovado, com ou sem emendas, pela assembléia de todos os cidadãos, a Ekklesia. Mas nenhum psephisma seria considerado válido se inconsistente com um nomos. Na verdade, dentro da centralidade da lei em sua politéia, as próprias leis deveriam conformar-se ao conjunto das nomoi consideradas essenciais à polis. Qualquer cidadão possuía legitimidade para proceder à argüição de defeito formal ou material
} 
O graphé paranomón era, fundamentalmente, um instrumento voltado à responsabilização penal daqueles que aprovaram uma lei inválida - embora acarretasse, igualmente, a invalidação dos decretos contrastantes com o direito divino e superior. Guarda, neste sentido, apenas uma vaga semelhança com a nossa ação direta de inconstitucionalidade. Por outro lado, há evidente semelhança na concepção da existência de uma lei superior, ou uma ordem jurídica superior, à qual as demais normas não podem desrespeitar, sob pena de invalidade.

Na Idade Média, o direito natural foi alçado a parâmetro de controle das leis, vinculando o legislador a seus valores. ${ }^{96}$ Ressalte-se, todavia, a dificuldade de sua utilização para tal finalidade, em virtude de se tratar de direito não escrito.

A ideia de uma ordem jurídica superior esteve presente, portanto, tanto na pólis grega como no direito medieval, e também está presente na atualidade, consubstanciada na Constituição, com a diferença de que esta costuma ser positivada em um documento escrito e rígido.

de quaisquer moções apresentadas, seja quanto a questões substanciais da nomos invocada, seja por defeito formal, através da graphé paranomon -algo como uma proto-ação de inconstitucionalidade - instituída, provavelmente, no século V a.C., após a época de Sólon, como nos informa Accioli. Tanto Wormuth como o jurista grego Ilias Arnaoutoglou, $\mathrm{PhD}$ em estudos clássicos pela Universidade de Glasgow, observam que a graphé paranomon era também usada contra a propositura de um psephisma inconsistente com um nomos. Além disso, era também vedada a propositura de uma lei conflitante com outras já existentes, mesmo que estas últimas não integrassem o conjunto das nomoi tidas como fundamentais, sem que as leis preexistentes fossem previamente anuladas, o que, por sua vez, consoante Arnaoutoglou, era argüível por meio da graphè nómon ne epitélion theînai.” Disponível em: <http://teses.ufrj.br/IFCS_M/LuizCarlosDeBarrosPenteado.pdf> Acesso em: $15 / 12 / 2009$.

96 "A concepção do direito e da justiça, dominante na Idade Média, se se ligava, em sentido latíssimo, ao pensamento de Platão e de Aristóteles, de que já se falou, ligava-se, porém, também e sobretudo, através da doutrina tomista, aos filósofos estóicos e a Cícero. Naquela concepção, a idéia de jus naturale assumia um lugar preeminente: o direito natural era configurado como a norma superior, de derivação divina, na qual todas as outras normas deviam ser inspiradas. Como escreve um jurista moderno, 'o ato soberano que tivesse infringido os limites postos pelo direito natural era declarado formalmente nulo e não vinculatório, tanto que o juiz competente para aplicar o direito era obrigado a considerar nulo (e por isto não obrigatório) seja o ato administrativo contrário ao direito (natural), seja a própria lei que se encontrasse em semelhante condição, mesmo que ela tivesse sido proclamada pelo Papa ou pelo Imperador.” In: CAPPELLETTI, Mauro. O Controle Judicial de Constitucionalidade das Leis no Direito Comparado. Rio Grande de Sul, Sérgio Fabris Editor, 1999, p. 51-52. 
Após a experiência grega, a democracia, como forma de exercício do poder, foi praticamente esquecida durante toda a Idade Média e só voltou ao cenário mundial com as revoluções liberais do século XVIII, mas com um formato que guardava apenas leve semelhança com a democracia grega. ${ }^{97}$ A democracia moderna volta-se a proteger a liberdade do indivíduo enquanto pessoa e não apenas como membro da polis.

A ideia de um governo do povo ressurge nas obras de

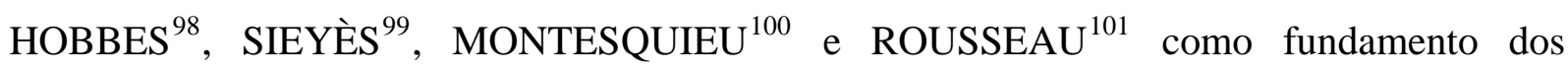
movimentos revolucionários da era moderna.

As revoluções liberais, insufladas fundamentalmente pela burguesia, tinham como objetivo a limitação do poder do soberano, de modo a garantir a liberdade para os cidadãos, em particular no tocante ao comércio.

Das revoluções ocorridas tanto na França como nos Estados Unidos da América, surgiram documentos escritos nos quais direitos eram proclamados, sendo erigidos a direitos fundamentais aos seres humanos (ou "ao homem e ao cidadão", como consta na Declaração de Direitos francesa de 1789).

Esses direitos exigiam, essencialmente, uma atitude passiva do Estado em relação ao cidadão, passando a ser conhecidos como liberdades públicas ou direitos humanos de primeira geração.

\footnotetext{
${ }^{97}$ De fato, como afirma SARTORI; “durante mais de dois mil anos, o termo democracia praticamente saiu de uso e perdeu completamente qualquer conotação elogiosa. Vamos deixar Tomás de Aquino falar por todos sobre a questão: 'Quando um regime realmente perverso (iniquum regimen) é conduzido por muitos (per multos), é chamado de democracia'. Durante esse longo período, os ocidentais falaram de república: e dizer res publica não é o mesmo que dizer democracia.” In: SARTORI, Giovanni, A teoria da democracia revisitada, vol. II: As questões clássicas. São Paulo, Editora Ática, 1994, p. 46.

${ }_{98}^{98}$ HOBBES, Thomas. Leviatã., São Paulo, Abril Cultural, 1974.

${ }^{99}$ SIEYĖS, Emmanuel Joseph. Qu'est-ce que lê Tiers État?, $3^{\text {a }}$ ed., Organização de Aurélio Wander Bastos, Rio de Janeiro, Lumen Juris, 1997.

${ }^{100}$ MONTESQUIEU, Charles de Secondat. O Espírito das Leis. Tradução Cristina Murachco, São Paulo, Martins Fontes, 1996.

${ }^{101}$ ROUSSEAU, Jean-Jacques. O Contrato Social e Outros Escritos, 15ª ed., São Paulo, Cultrix, 2005.
} 
A importância das Constituições na era moderna foi bem ressaltada por CEZAR SALDANHA, para quem, o cerne da ideia liberal das revoluções setecentistas está "na crença na capacidade do direito para regular e limitar o Estado e a política, por meio de uma lei, a Constituição, que, de alguma forma, provenha autonomamente da representação nacional”. 102

Mas de nada adiantaria a declaração de tais direitos se o legislador ou administrador incautos ou malintencionados pudessem subvertê-los por meio de lei ordinária, aprovada mediante a formação de uma maioria parlamentar conjuntural ou mesmo passional, ou mediante simples ato do chefe de governo. ${ }^{103}$

Assim, os idealizadores das novas Constituições, tanto no continente europeu como no americano, já previam a necessidade de uma instância destinada a filtrar a legislação infraconstitucional de modo a expurgar as leis ou atos normativos que conflitassem com a Constituição.

SIEYÈS forjou um instrumento para tal finalidade, que chegou a ser inserido na Constituição de 22 frimário do ano VIII (13 de dezembro de 1799), ficando a cargo do Senado (Sénat Conservateur) a eliminação das leis ordinárias inconstitucionais. Todavia, como se sabe, na vigência daquela Constituição NAPOLEÃO BONAPARTE exerceu o poder de maneira absoluta e praticou inúmeros atos inconstitucionais, nunca sancionados, tendo, inclusive, ascendido a Primeiro-Cônsul e, em seguida, a Imperador dos franceses, o que, obviamente, não era permitido pela Constituição. ${ }^{104}$

\footnotetext{
${ }^{102}$ SALDANHA, Cezar. O Tribunal Constitucional como Poder. São Paulo, Memória Jurídica Editora, 2002, p. 104-105.

${ }^{103}$ A distinção entre a Constituição e as demais leis é bem colocada na obra de VATTEL, ao abordar a questão acerca de ser ou não facultado a ele mudar a Constituição: "A constituição do Estado deve ser estável, e desde que a Nação a estabeleceu em primeiro lugar e que, em seguida, confiou o poder legislativo a certas pessoas, as leis fundamentais são retiradas da competência delas. Nota-se que a sociedade apenas desejou prover que o Estado fosse sempre munido de leis convenientes às conjunturas ao dar aos legisladores, par este efeito, o poder de abrogar leis civis antigas e leis políticas não fundamentais, e de fazer novas leis; mas nada nos permite pensar que a sociedade tenha desejado submeter a sua constituição à vontade deles. Numa palavra, é da constituição que esses legisladores recebem o seu poder; como então, eles poderiam mudá-la sem destruir o fundamento da sua própria autoridade?” In: VATTEL, Emer de. O direito das gentes. Brasília, Instituto de Pesquisa de Relações Internacionais-Editora Universidade de Brasília, 2004, p. 30.

${ }^{104}$ FERREIRA FILHO, Manoel Gonçalves. O Poder Constituinte. São Paulo, Saraiva, 5a ed., 2007, p. 17.
} 
A confiança nos tribunais para fazer cumprir a Constituição é, segundo alguns, uma contribuição tipicamente norte-americana à ciência política. ${ }^{105}$

Ao contrário da França, onde os juízes eram mal vistos, pois identificados com o ancien régime, conhecidos como "a nobreza de toga" - sabe-se que o cargo de juiz representava um direito de propriedade, passível de ser herdado e sujeito à venda (embora somente os nobres pudessem adquiri-lo) e usufruído ao máximo, sempre às custas das partes -, ou da Inglaterra, País no qual, desde a "gloriosa revolução” prevalece o princípio da soberania do Parlamento, a impedir o controle da obra parlamentar pelos tribunais; nos Estados Unidos, a ideia de controlar as leis segundo matrizes superiores era natural e decorria do processo de colonização daquele país. ${ }^{106}$

É verdade que a própria Inglaterra, em seu breve período republicano, já no Século XVII, havia passado por uma experiência de tentativa de instauração de um sistema de proteção da ordem vigente do Commonwealth. ${ }^{107}$

\footnotetext{
${ }^{105}$ Nesse sentido: GRANT, James A. Constituição, El Control Jurisdiccional de la Constitucionalidad de las Leyes: Una Contribuición de las Américas a la Ciencia Política. Publicacion de la México, Revista de la Facultad de Derecho de México, 1963, apud CAPPELLETTI, Mauro. O Controle Judicial de Constitucionalidade das Leis no Direito Comparado. Rio Grande de Sul, Sérgio Fabris Editor, 1999, p. 46.

${ }^{106}$ Segundo informa CAMPILONGO: "Rediscutir o papel do Judiciário nesse momento passa, inicialmente, por uma análise da divisão de poderes. 'Divisão de poderes' é um dos conceitos mais complexos da teoria constitucional. Em primeiro lugar, pode-se dizer que o modelo concebido por Montesquieu deu origem a duas visões distintas da função do Judiciário: na tradição do direito continental, o juiz é a 'boca da lei' e está limitado pelo Legislativo; na tradição da 'common law', o magistrado é garante da Constituição e impõe limites ao Legislativo. Dito por outras palavras: a recepção de Montesquieu na França pós-revolucinária foi caucionada por um contexto que via no poder dos juízes (em larga medida, vinculados ao 'ancien régime') o inimigo a ser combatido; para o constitucionalismo americano, ao contrário, a maior ameaça provém das maiorias democráticas (o temor diante da 'tirania da maioria').” In: CAMPILONGO, Celso. Política, sistema jurídico e decisão judicial. São Paulo, Max Limonad, 2002, p. 30.

107 "O clamor por um guardião e defensor da Constituição é, na maioria das vezes, um sinal de delicadas condições constitucionais. Por isso, é instrutivo e digno de consideração o fato de os planos e as propostas de tal guardião surgirem na recente história constitucional primeiramente na Inglaterra, mais precisamente após a morte de Cromwell (1658), ou seja, após as primeiras tentativas modernas de constituições escritas e em uma época de desligamento da política interna do governo republicano, em virtude de um parlamento incapaz de deliberações objetivas e diretamente antes da restauração da Monarquia. Naquele tempo foi proposta uma corporação especial que, seguindo o modelo éforo espartano, deveria defender a ordem vigente do Commonwealth e impedir a restauração da monarquia.” In: SCHIMITT, Carl. O guardião da Constituição. Tradução Luiz Moreira, Belo Horizonte, Del Rey, 2007, p. 1.
} 
Todavia, o controle de constitucionalidade de moldes atuais tem suas origens mais sólidas no período de formação das Constituições escritas cunhadas a partir das revoluções liberais do século XVIII, inseridas em um cenário de superação do absolutismo, separação de poderes e sua consequente limitação, percepção da sociedade destacada do Estado, e individualismo. ${ }^{108}$

\subsubsection{O controle de origem estadunidense}

É interessante notar que foi justamente a soberania do Parlamento inglês que favoreceu a denominada “supremacia dos juízes” nos Estados Unidos da América.

De fato, como explica CAPPELLETTI, a teoria da supremacia da common law sobre o Parlamento já era defendida por COKE no ordenamento inglês. A lei estatutária poderia ser rejeitada pela common law no caso de ser a ela contrária. E, segundo Lord COKE, seriam os juízes que deveriam garantir, a final de contas, a soberania da common law. ${ }^{109}$

A doutrina de Lord COKE, continua CAPPELLETTI, entendida como instrumento de luta, quer contra o absolutismo do Rei, que contra o do Parlamento, predominou na Inglaterra por alguns decênios, e não só na Inglaterra, mas também nas colônias inglesas da América, onde foi, de fato, em muitas ocasiões, acolhida pelos

${ }^{108}$ Segundo CAMPILONGO: "Paralelamente ao princípio da divisão dos poderes afirmam-se outros dois importantes aspectos do pensamento liberal-burguês: a separação Estado/sociedade e o individualismo. A superação do absolutismo envolve gradual estabilização desses três componentes: a mudança de um modelo político mono-hierárquico para uma estrutura anti-hierárquica da divisão de poderes; a passagem de uma concepção que não diferencia com clareza as tarefas do Estado daquelas da sociedade civil para uma postura que traça uma rígida demarcação dos limites do Estado e das esferas de liberdade que o sistema jurídico deve reconhecer e garantir ao cidadão; a transformação de uma sociedade estratificada em "Estados' numa sociedade na qual todos são iguais em suas esferas de liberdade e recebem do Estado um tratamento formalmente idêntico.” In: CAMPILONGO, Celso Fernandes. Política, Sistema Jurídico e Decisão Judicial. São Paulo, Max Limonad, 2002, p. 32-33.

${ }^{109}$ CAPPELLETTI, Mauro. O Controle Judicial de Constitucionalidade das Leis no Direito Comparado. Rio Grande de Sul, Sérgio Fabris Editor, 1999, p. 59-60. 
tribunais $^{110}$, tendo sido, contudo, abandonada na Inglaterra com a revolução de 1688, a partir de quando proclamou-se a doutrina contrária, da supremacia do Parlamento.

E, arremata COKE, as Colônias inglesas foram constituídas como companhias comerciais, por meio de cartas ou estatutos da Coroa. Estas "cartas" poderiam ser consideradas as primeiras Constituições das Colônias, pois vinculavam o legislador local, que, embora pudesse editar leis locais, deveria fazê-lo de maneira que fossem razoáveis e não violassem as leis do Reino da Inglaterra e, por via de consequência, a supremacia do Parlamento. Partindo dessas premissas, em numerosos casos, o Privy Concil do Rei decidiu que as leis coloniais deviam ser aplicadas pelos juízes das Colônias só se elas não estivessem em contraste com as leis do Reino. ${ }^{111}$

Dessa forma, os juízes americanos foram se afeiçoando à prática de controlar a legalidade das leis locais. Após a independência em relação à Inglaterra, ocorrida em 1776, os Estados aprovaram suas próprias Constituições, em substituição às antigas “Cartas”, e em pouco tempo as Constituições locais foram substituindo as leis do Reino como parâmetro para o controle da legislação.

As ideias que ensejariam a aplicação da judicial review já estavam presentes na formação da federação americana, tendo sido claramente sustentadas por ALEXANDER HAMILTON, nos arts. LXXVIII ${ }^{112}$ e LXXXI, de Os Artigos Federalistas.

\footnotetext{
${ }^{110}$ CAPPELLETTI, Mauro. O Controle Judicial de Constitucionalidade das Leis no Direito Comparado. Rio Grande de Sul, Sérgio Fabris Editor, 1999, p. 60.

${ }^{111}$ Ibidem, p. 61.

112 “A completa independência dos tribunais de justiça é peculiarmente essencial numa Constituição limitada. Por Constituição limitada, entendo uma que contenha certas exceções especificas ao pode legislativo, como, por exemplo, a de que ele não aprovará decretos de perda dos direitos civis, leis ex post facto, ou coisas semelhantes. Na prática, limitações desse tipo não podem ser preservadas senão por meio de tribunais de justiça, cuja missão deverá ser declarar nulos todos os atos contrários ao sentimento manifesto da Constituição. Sem isto, todas as restrições a direitos ou privilégios particulares equivaleriam a nada. [...] Não há posição fundada em princípios mais claros que aquela de que todo ato de um poder delegado que contrarie o mandato sob o qual é exercido é nulo. Portanto, nenhum ato legislativo contrário à Constituição pode ser válido. Negar isto seria afirmar que o delegado é maior que o outorgante; que o servidor está acima do senhor; que os representantes do povo são superiores ao próprio povo; que homens que atuam em virtude de poderes a eles confiados podem fazer não só o que estes autorizam, mas o que proíbem. [...] A interpretação das leis é o domínio próprio e particular dos tribunais. Uma Constituição é de fato uma lei fundamental, e como tal deve ser vista pelos juízes. Cabe a eles, portanto, definir seu significado tanto quanto o significado de qualquer ato particular procedente do corpo
} 
RUI BARBOSA enfatiza, ao comentar o poder de os tribunais declararem a nulidade das leis inconstitucionais, que "desde os tempos coloniais a jurisprudência americana se detinha ante esta questão, e várias vezes a resolvia, atribuindo esse poder, como função privativa, aos tribunais”. ${ }^{113}$ Cita, então, decisões de 1870, do Supremo Tribunal de Nova Jérsei; de 1782, da magistratura de Virgínia; de 1786, de Rhode Island; e de 1788, da Carolina do Norte, nas quais houve o reconhecimento da invalidade das leis inconstitucionais. ${ }^{114}$

O mais emblemático episódio na jurisprudência americana, todavia, ocorreu em 1803, no famoso caso MARBURY versus MADISON, no qual a Suprema Corte americana, em decisão proferida por MARSHALL, então Presidente daquele tribunal, delineou os contornos do raciocínio que proclama a invalidade, nulidade absoluta, da lei que contrarie a Constituição. ${ }^{115}$

O sistema de controle estadunidense teve grande repercussão e foi incorporado ao ordenamento jurídico de diversos outros países. CAPPELLETTI informa que este modelo foi implantado, sobretudo, em muitas ex-colônias inglesas, como o Canadá, a Austrália e a Índia, mas também, em outras partes, como no Japão, na Suíça, na Noruega, na Dinamarca, na Suécia, bem como, na Alemanha, durante a Constituição de Weimar, e na Itália, de 1948 a $1956 .{ }^{116} 117$

legislativo. Caso ocorra uma divergência irreconciliável entre ambos, aquele que tem maior obrigatoriedade e validade deve, evidentemente, ser preferido. Em outras palavras, a Constituição deve ser preferida ao estatuto, a intenção do povo à intenção de seus agentes. Esta conclusão não supõe de modo algum uma superioridade do poder judiciário sobre o legislativo. Supõe apenas que o poder do povo é superior a ambos, e que, quando a vontade do legislativo, expressa em suas leis, entra em oposição com a do povo, expressa na Constituição, os juízes devem ser governados por esta última e não pelas primeiras. Devem regular suas decisões pelas leis fundamentais, não pelas que não são fundamentais.” In: MADISON, James; HAMILTON, Alexander; JAY, John. Os Artigos Federalistas: 1787-1788. Rio de Janeiro, Nova Fronteira, 1993, p. 480-481.

${ }^{113}$ BARBOSA, Rui. Atos Inconstitucionais. 2a ed., São Paulo, Russel, 2004, p. 47.

${ }^{114}$ Veja-se a tradução de RUI BARBOSA (Ibidem, p. 47-48) acerca dos pontos fundamentais da referida decisão.

${ }^{115}$ A transcrição da decisão foi feita, em sua parte essencial, por RUI BARBOSA, In: Ibidem, p. 49-52.

${ }^{116}$ CAPPELLETTI, Mauro. O Controle Judicial de Constitucionalidade das Leis no Direito Comparado. Rio Grande de Sul, Sérgio Fabris Editor, p. 68-72.

${ }^{117}$ BARACHO esclarece que: "Distantes do modelo europeu estão a Dinamarca, a Irlanda, a Noruega, a Suécia e a Grécia, que optaram pelo modelo americano. A Suíça apresenta situação particular. A Grã-Bretanha, os Países Baixos e Luxemburgo são desprovidos de todo sistema de Justiça Constitucional.” In: BARACHO, José Alfredo 
Como se sabe, foi, igualmente, adotado pelo ordenamento jurídico brasileiro, em 1890, após a proclamação da República, e é, também, o sistema tradicional português, “introduzido na Constituição de 1911 (art. 63º), por influência da Constituição brasileira de 1891 (arts. 207 e 280)”. ${ }^{118}$

\subsubsection{O controle de origem austríaca}

Ao que tudo indica, o modelo estadunidense de controle de constitucionalidade não se incorporou satisfatoriamente na maior parte da Europa.

A par das diferenças históricas entre a evolução do direito europeu e do norte-americano, a maior dificuldade de implantação do sistema de controle difuso nos países de tradição romanística (civil law) encontra-se na inexistência, nestes, do princípio da vinculação dos precedentes (stare decisis) americano.

Segundo o princípio da stare decisis, as decisões dos órgãos superiores de uma jurisdição vinculam os órgãos jurisdicionais inferiores, de modo que a declaração de inconstitucionalidade de um ato normativo pela instância superior impede as inferiores de aplicarem aquela lei ou ato normativo, ao passo que a decisão da Suprema Corte impede a aplicação da lei em termos gerais. ${ }^{119}$ Assim, esclarece CAPPELLETTI que, embora

de Oliveira. Direito processual constitucional. Aspectos contemporâneos. Editora Fórum. Belo Horizonte, 2006, p. 19.

${ }^{118}$ CANOTILHO, Joaquim José Gomes. Direito Constitucional e Teoria da Constituição. $7^{\mathrm{a}}$ ed., Coimbra, Almedina, 2003, p. 898.

${ }^{119}$ Segundo CAPPELLETTI: “O resultado final do princípio do vínculo aos precedentes é que, embora também nas Cortes (estaduais e federais) norte-americanas possam surgir divergências quanto à constitucionalidade de uma determinada lei, através do sistema das impugnações a questão de constitucionalidade poderá acabar, porém, por ser decidida pelos órgãos judiciários superiores e, em particular, pela Supreme Court cuja decisão será, daquele momento em diante, vinculatória para todos os órgãos judiciários. Em outras palavras, o princípio do stare decisis opera de modo tal que o julgamento de inconstitucionalidade da lei acaba, indiretamente, por assumir uma verdadeira eficácia erga omnes e não se limita então a trazer consigo o puro e simples efeito da não aplicação da lei a um caso concreto com possibilidade, no entanto, de que em outros casos a lei seja, ao invés, de 
a lei continue em vigor (on the books), é transformada em lei morta (a dead law), convertendo-se, por força da stare decisis, a mera não aplicação da lei ao caso concreto em verdadeira anulação da lei, com efeitos gerais (erga omnes). ${ }^{120}$

Com vistas a tornar o controle de constitucionalidade palatável à história e realidade européias, HANS KELSEN formulou um sistema de proteção da Constituição diferenciado do americano, cujas premissas básicas procurarei demonstrar a seguir.

No sistema conhecido como austríaco, em virtude de ter sido adotado pioneiramente pela Constituição da Áustria de 1920, o controle de constitucionalidade é exercido de forma concentrada pela Corte Constitucional. Para instauração do controle, a Constituição austríaca exigia, como esclarece CAPPELLETTI, a formulação de um pedido especial (Antrag), a cargo de determinados órgãos - inicialmente apenas de caráter político -, a dar início a uma ação também especial, totalmente desvinculada de qualquer caso concreto. ${ }^{121}$ Consubstanciava-se em um controle por via principal - e não incidental como o modelo americano -, no qual os juízes, à exceção da Corte Constitucional, não tinham o poder de controlar a constitucionalidade das leis e tampouco de deixar de aplicá-las se as reputassem inconstitucionais. ${ }^{122}$ A reforma de 1929 atribuiu a dois órgãos judiciários ordinários (a Corte Suprema para as causas civis e penais e a Corte Suprema para as causas administrativas) a legitimidade para a instauração do processo, mas, neste caso, em via incidental. ${ }^{123}$

O sistema austríaco era dotado de inegável originalidade, como bem enfocado por BARACHO:

“A Constituição austríaca transformou-se em modelo de um sistema de controle de constitucionalidade, verdadeiramente original, que se opõe ao

novo aplicada”. In: CAPPELLETTI, Mauro. O Controle Judicial de Constitucionalidade das Leis no Direito Comparado. Rio Grande de Sul, Sérgio Fabris Editor, 1999, p. 80-81.

${ }^{120}$ Ibidem, p. 81-82.

${ }^{121}$ Ibidem, p. 104.

${ }^{122}$ Ibidem, p. 105.

${ }^{123}$ Ibidem, p. 106. 
sistema americano, criando o tipo de controle concentrado. Trata-se de instituição especializada que realiza seu controle por intermédio de procedimentos especiais, podendo anular a norma inconstitucional, com efeito erga omnes. Esse tipo de controle, instituído na Áustria, permite o controle 'abstrato' e o ‘concreto'.,"124

Como lembra CANOTILHO, "qualquer que seja a sua caracterização jurídico-constitucional, este sistema encontrou grande recepção no apósGuerra, estando consagrado na Itália, Alemanha, Turquia, Jugoslávia, Chipre, Grécia, Espanha e Portugal”. 125

Um rol dos países nos quais este modelo foi implantado é fornecido por BARACHO:

"O modelo europeu apareceu nos anos de 1920, sendo que entre as duas guerras foi conhecido: na Áustria (1920-1936), na Checoslováquia (19201938) e na Espanha republicana (1931-1939).”126

E acrescenta, o ilustre professor, a razão de ser de sua nomenclatura, bem como a abrangência que o sistema alcançou no pós-guerra:

"É conhecido como 'modelo austríaco', desde que a Alta Corte Constitucional da Áustria foi uma das suas primeiras ilustrações, que teve em Hans Kelsen seu primeiro teórico. Após a Segunda Guerra mundial ele foi adotado por várias constituições da Europa: República Federal da Alemanha, em 1949; Itália, em 1948; França, em 1958; Chipre, em 1960; Turquia em 1961; Portugal em 1976; Espanha em 1978; Bélgica em 1984 e a Iugoslávia em 1963, Hungria em 1985. Novas Cortes Constitucionais, como as da Hungria, Romênia, Eslovênia, Bulgária e Rússia e outras, ainda em formação na Europa central e oriental, vêm seguindo a mesma orientação.",127

${ }^{124}$ BARACHO, José Alfredo de Oliveira. Direito processual constitucional. Aspectos contemporâneos. Editora Fórum. Belo Horizonte, 2006, p. 24.

${ }^{125}$ CANOTILHO, Joaquim José Gomes. Direito Constitucional e Teoria da Constituição. $7^{\mathrm{a}}$ ed., Coimbra, Almedina, 2003, p. 899. É necessário ressaltar que na Grécia e em Portugal o sistema é essencialmente difuso, nos moldes norteamericanos, com a peculiaridade de prever um incidente de inconstitucionalidade cuja decisão tem caráter geral.

${ }^{126}$ BARACHO, José Alfredo de Oliveira. Direito processual constitucional: Aspectos contemporâneos. Editora Fórum, Belo Horizonte, 2006, p. 28.

${ }^{127}$ Ibidem, p. 28. 
Com fundamento neste brevíssimo histórico, é possível delinear as características fundamentais de cada um dos principais modelos de fiscalização sucessiva ${ }^{128}$ de constitucionalidade.

\subsection{Os modelos de controle de constitucionalidade}

\section{Consoante se pode notar pelo exame da evolução histórica do} controle de constitucionalidade, formaram-se dois principais modelos de controle repressivo ou a posteriori $^{129}$ de constitucionalidade: o modelo estadunidense e o modelo austríaco.

Os pontos principais que identificam cada um destes modelos serão a seguir apontados em breves considerações.

\footnotetext{
${ }^{128}$ A fiscalização prévia de constitucionalidade, que ocorre antes da aprovação da lei ensejaria a conformação de um terceiro modelo de verificação de constitucionalidade, que poderia ser denominado de modelo francês.

${ }^{129}$ A noção de controle repressivo, ou a posteriori, contrapõe-se à de controle preventivo de constitucionalidade. Neste último, a fiscalização é feita antes da entrada da lei em vigor, como ocorre no sistema francês, que pode ser considerado modelo desta espécie, prévia, de fiscalização. Todavia, como a fiscalização no modelo francês ocorre em meio ao processo legislativo, não se pretende analisá-la neste trabalho, no qual serão examinados os princípios processuais, extraídos da atividade jurisdicional, aplicáveis ao processo de controle concentrado de constitucionalidade. Acresça-se, a título de elucidação, que recente alteração na Constituição francesa, decorrente da revisão constitucional ocorrida em julho de 2008, inseriu, por meio do artigo 61-1, hipótese de controle de constitucionalidade repressivo ou a posteriori, no sistema francês, mas apenas no que diz respeito à violação de direitos e liberdades garantidos na Constituição. Referido sistema entrará em vigor em $1^{\circ}$ de março de 2010 e deverá ser regulamentado por meio de lei orgânica, que disciplinará as condições de aplicação da nova competência. O dispositivo mencionado possui a seguinte redação: "Article 61-1. Lorsque, à l'occasion d'une instance en cours devante une juridiction, il est soutenu qu'une disposition législative porte atteinte aux droits et libertés que la Constitution garantit, le Conseil constitutionnel peut être saisi de cette question sur renvoi du Conseil d'État ou de la Cour de cassation que se prononce dans un délai déterminé.

Une loi organique détermine les conditions d'application du présent article.” Ou, 7em tradução livre do autor: "Artigo 61-1 - Quando, por ocasião de demanda em curso perante determinada ordem jurisdicional, for alegado que uma disposição legislativa viola direitos e liberdades que a Constituição garante, o Conselho Constitucional pode ser provocado a propósito dessa questão, por reenvio do Conselho de Estado ou da Corte de Cassação, pronunciando-se em prazo determinado. Lei orgânica determinará as condições de aplicação do presente artigo.”.
} 


\subsubsection{O modelo estadunidense ou difuso}

O sistema de controle de constitucionalidade americano, também conhecido como judicial review (of constitutionality of legislation), foi forjado na prática jurisprudencial e, como visto, sob a égide de uma Constituição que não o prevê expressamente.

É reconhecida a todo e qualquer juiz a competência para, julgando um caso concreto, deixar de aplicar determinada lei, declarando-a inconstitucional; por isso é conhecido como sistema difuso, no qual todos os órgãos do Poder Judiciário têm competência para conhecer da questão constitucional e, se necessário à resolução do caso concreto, declarar a inconstitucionalidade da lei.

Caracterizam o sistema difuso de controle de constitucionalidade os seguintes elementos: (i) a existência de um caso concreto - o Poder Judiciário é chamado a resolver uma lide e, incidentalmente, soluciona a questão constitucional com vistas a alcançar a decisão de mérito; (ii) a questão constitucional não é o objeto da lide e sim questão prejudicial ao exame do mérito; (iii) a inconstitucionalidade é alegada por via de exceção, entendida em seu sentido processual amplo como qualquer meio de defesa utilizado; (iv) a decisão proferida vale apenas inter partes; portanto, (v) a lei é considerada inválidada desde o seu nascedouro; (vi) a inconstitucionalidade é preexistente e a decisão judicial apenas a declara; (vii) ocorre a retroatividade imprópria dos efeitos da decisão, que afeta a validade da lei a partir da data de sua edição (efeitos ex tunc) ${ }^{130}$; (viii) há

130 Segundo o magistério de ELIVAL DA SILVA RAMOS:"Em face da categoria de sanção de inconstitucionalidade acolhida em nosso ordenamento, a decisão do Supremo Tribunal Federal nas ações diretas possui natureza declaratória, apresentando a chamada retroatividade imprópria, consistente em atestar a ineficácia total, $a b$ initio, da lei impugnada, por força da sanção de nulidade aplicada pelo próprio sistema normativo. Outra conseqüência da sanção de nulidade é a aparente repristinação da lei revogada por outra declarada inconstitucional; o que, na verdade, se verifica é a constatação da ineficácia revocatória dessa última, do que decorre a manutenção da vigência daquela, ressalvada revogação por outro motivo ou inconstitucionalidade.” In: RAMOS, Elival da Silva. A inconstitucionalidade das leis, vício e sanção. São Paulo, Saraiva, 1994 , p. 118. 
aparente repristinação ${ }^{131}$ de legislação anterior revogada pela lei declarada inconstitucional, aplicada no caso concreto apenas.

\subsubsection{O modelo austríaco ou concentrado}

O modelo austríaco de controle consiste em uma fiscalização concentrada de constitucionalidade, na qual a competência para exercer o controle é atribuída a um único órgão, o tribunal ou corte constitucional. A ação destinada ao controle de constitucionalidade é peculiar, tem legitimados e rito próprios, sendo o exame de constitucionalidade da norma o seu objetivo. A decisão proferida nesse sistema vale para todos (erga omnes) e produz efeitos desconstitutivos (ou constitutivos negativos), retirando o ato normativo do ordenamento jurídico a partir do momento em que a decisão é proferida.

São características gerais do sistema austríaco, que podem estar presentes em maior ou menor grau nos ordenamentos que adotam este modelo: (i) as Cortes Constitucionais não pertencem à estrutura do Poder Judiciário ${ }^{132}$; (ii) a legitimidade para

\footnotetext{
${ }^{131}$ Na verdade, não se trata de efeito repristinatório, como bem explica ELIVAL DA SILVA RAMOS: "Em outras palavras, não é o provimento jurisdicional que, reconhecendo a inconstitucionalidade do ato controlado, desconstitui os seus efeitos, retroativamente, desde a sua edição; o ato normativo controlado se caracteriza por uma ineficácia congênita, exatamente por não haver sequer entrado no plano da validade, ineficácia essa que é apenas reconhecida pela decisão de controle, decisão, insista-se, de natureza meramente declaratória. Portanto, nos sistemas jurídicos em que se adota a sanção de nulidade, para o ato inconstitucional a decisão de controle não apresenta propriamente efeitos retroativos; pode-se falar sim em uma aparência de retroatividade ou em uma retroatividade imprópria, que consiste, precisamente, no reconhecimento da sanção imposta $a b$ initio pelo ordenamento.” In: RAMOS, Elival da Silva. Perspectivas de evolução do controle de constitucionalidade no Brasil. 2005, 466 f., tese (provimento de cargo de professor titular), Universidade de São Paulo, Faculdade de Direito, Departamento de Direito do Estado - Direito Constitucional, São Paulo, 2005, p. 84.

${ }^{132}$ Ao fazer um paralelo com a Suprema Corte americana, BARACHO pondera que: "A Corte Constitucional é uma jurisdição criada pra conhecer especial e exclusivamente o contencioso constitucional, situada fora do aparelho jurisdicional ordinário e independente, como ocorre com os outros modelos dos demais poderes públicos. É uma jurisdição especializada, com a competência exclusiva e situada fora do aparelho judiciário comum. Enquanto que a Corte Constitucional é uma jurisdição 'especializada', a Corte suprema é uma jurisdição 'generalista'. A Corte suprema conhece de todos os contenciosos (civil, administrativo, penal, comercial ou constitucional), enquanto a Corte Constitucional é exclusivamente competente para apreciar matéria constitucional. A Corte Constitucional é jurisdição 'especializada', de competência exclusiva. Ela monopoliza o julgamento do contencioso constitucional. Não faz, normalmente, parte da organização jurisdicional ordinária.” In: BARACHO, José Alfredo de Oliveira. Direito processual constitucional: Aspectos contemporâneos. Editora Fórum, Belo Horizonte, 2006, p. 30-31.
} 
propor a ação de verificação de constitucionalidade recai sobre entes ou autoridades públicas, tribunais ou indivíduos; (iii) a fiscalização de constitucionalidade é realizada de forma concentrada (abstrata ou concreta), atribuindo-se a um único órgão a competência para o conhecimento da ação ou do incidente de inconstitucionalidade; (iv) a arguição da inconstitucionalidade pode ser realizada tanto por meio da ação direta, como através de um recurso constitucional ou pela via incidental); (v) a ação direta, os recursos constitucionais e os incidentes têm por objeto a própria verificação da constitucionalidade do ato normativo; (vi) a ação direta possui procedimento especial, com regras próprias e, eventualmente, distintas dos demais procedimentos processuais; (vii) a decisão que reconhece a inconstitucionalidade tem caráter desconstitutivo (constitutivo negativo) e não declaratório; assim, (ix) o reconhecimento da inconstitucionalidade tem, em regra, eficácia para o futuro (efeitos ex nunc) ou retroagir, podendo o tribunal, inclusive, fixar termo para a retirada da lei do ordenamento jurídico; e, por fim, (x) a decisão tem eficácia geral, erga omnes, semelhante a um ato legislativo revocatório.

\subsubsection{O modelo adotado no Brasil: uma breve evolução histórica}

No Brasil, como lembra LÚCIO BITTENCOURT ${ }^{133}$, com o advento da República o mecanismo de controle de inspiração americana apareceu, de forma perfeitamente nítida, na Constituição Provisória de 22 de junho de 1890 (art. 58, § 1º, alínea b), e no Decreto $n^{\circ} 848$, de 11 de outubro do mesmo ano, que organizou a Justiça Federal. A Constituição de 1891 previu, na alínea $b$ do $\S 1^{\circ}$ do artigo 59, que:

“Art. 59. Ao Supremo Tribunal Federal compete:

[...]

$\S 1^{\circ}$ - Das sentenças das justiças dos Estados, em última instância, haverá recurso para o Supremo Tribunal Federal;

$[\ldots]$

${ }^{133}$ BITTENCOURT, Lúcio. O Controle de constitucionalidade das leis. Forense, Rio de Janeiro, 2ª ed., 1968, p. 28. 
b) quando se contestar a validade de leis ou atos dos governos dos Estados em face da Constituição, ou das leis federais, e a decisão do tribunal do Estado considerar válidos estes atos, ou essas leis impugnadas.”

Por sua vez, a Lei $\mathrm{n}^{\circ}$ 221, de 20 de novembro de 1894, que dispôs sobre a organização da Justiça Federal da República, previu, no § 10 de seu art. 13, que:

"Os juízes e tribunais apreciarão a validade das leis e regulamentos e deixarão de aplicar aos casos ocorrentes e as leis manifestamente inconstitucionais e os regulamentos manifestamente incompatíveis com as leis ou com a Constituição.”

Estava, portanto, criado o sistema de controle de constitucionalidade nos moldes norte-americanos: difuso (ou seja, de competência de todos os órgãos do Poder Judiciário), incidental (em um processo entre partes) e repressivo (após a entrada em vigor do ato normativo).

A Constituição promulgada em 1934 manteve o controle de constitucionalidade difuso, incidental e repressivo ou sucessivo, inserindo algumas normas voltadas à adequação da fiscalização de constitucionalidade ao ordenamento jurídico brasileiro.

Procurou-se, na Constituição de 1934, criar um mecanismo destinado a conferir à decisão do Supremo Tribunal Federal eficácia geral, erga omnes, com vistas a suprir a falta do stare decisis existente no modelo de origem estadunidense. ${ }^{134}$

Assim, foi atribuída ao Senado (art. 91, IV, da Constituição de 1934) a competência para “suspender a execução, no todo ou em parte, de qualquer lei ou ato,

\footnotetext{
${ }^{134}$ Esclarece ELIVAL DA SILVA RAMOS que: “Com as resoluções senatoriais, suspensivas da execução de leis ou atos normativos, declarados inconstitucionais, incidental e concretamente, pelo Supremo Tribunal Federal, se procurou obviar o notório inconveniente da disparidade das decisões que o sistema de controle de constitucionalidade de matriz estadunidense provoca, em ordenamentos filiados ao civil law, desconhecedores da regra do stare decisis, sem abalar, entretanto, as vigas-mestras do modelo.” In: RAMOS, Elival da Silva. Perspectivas de evolução do controle de constitucionalidade no Brasil. 2005, 466 f., tese (provimento de cargo de professor titular), Universidade de São Paulo, Faculdade de Direito, Departamento de Direito do Estado - Direito Constitucional, São Paulo, 2005, p. 185.
} 
deliberação ou regulamento, quando hajam sido declarados inconstitucionais pelo Poder Judiciário”, cabendo ao Procurador-Geral da República, em face de declaração de inconstitucionalidade proferida pelo Supremo Tribunal Federal, comunicar a “decisão ao Senado Federal para os fins do art. 91, n. IV, e bem assim à autoridade legislativa ou executiva, de que tenha emanado a lei ou ato” (art. 96).

Mecanismo semelhante esteve presente nas Constituições posteriores, com exceção da Constituição de 1937. A Carta atual o prevê, no inciso X do artigo 52, como competência privativa do Senado Federal.

A Constituição de 1934, seguindo a exigência fixada pela jurisprudência norte-americana, fixou a exigência da maioria absoluta dos votos dos membros do tribunal para a declaração de inconstitucionalidade (art. 179). ${ }^{135} \mathrm{Na}$ doutrina norteamericana, a regra é conhecida como full bench, full court, ou en banc, que passaria a estar presente em todas as demais Constituições brasileiras.

A Constituição de 1934 criou, por fim, como competência originária do Supremo Tribunal Federal, a representação interventiva, figurando o ProcuradorGeral da República como legitimado à sua propositura. ${ }^{136}$

Com o Estado Novo, institui-se um regime de centralização do poder, no qual a Constituição poderia ser considerada mero instrumento retórico, destinada a

\footnotetext{
135 “Art 179 - Só por maioria absoluta de votos da totalidade dos seus Juízes, poderão os Tribunais declarar a inconstitucionalidade de lei ou ato do Poder Público.”

${ }^{136}$ IVES GANDRA DA SILVA MARTNS e GILMAR FERREIRA MENDES pontuam acerca da significativa inovação: "Talvez a mais fecunda e inovadora alteração introduzida pelo Texto Magno de 1934 se refira à 'declaração de inconstitucionalidade para evitar a intervenção federal', tal como a denominou Bandeira de Mello, isto é, a representação interventiva, confiada ao Procurador-Geral da República, nas hipóteses de ofensa aos princípios consagrados no art. 7º, I, $a$ a $h$, da Constituição. Cuidava-se de fórmula peculiar de composição judicial dos conflitos federativos, que condicionava a eficácia da lei interventiva, de iniciativa do Senado (art. 41, $\S 3$ 3), à declaração de sua constitucionalidade pelo Supremo Tribunal (art. 12, § 2º). [...] Esse controle judicial configurava, segundo Pedro Calmon, um sucedâneo do direito de veto, atribuindo-se à Suprema Corte o poder de declarar a constitucionalidade da lei de intervenção e firmar, ipso facto, a inconstitucionalidade da lei ou ato estadual. Advirta-se, porém, que não se tratava de formulação de um juízo político, exclusivo do Poder Legislativo, mas de exame puramente jurídico”. In: MARTNS, Ives Gandra da Silva; MENDES, Gilmar Ferreira. Controle concentrado de constitucionalidade. $3^{\mathrm{a}}$ ed., São Paulo, Saraiva, 2009, p. 48-49.
} 
legitimá-lo. A Constituição de 1937 poderia ser citada como exemplo da anomalia constitucional que LOWENSTEIN denominou de “constituição semântica”, como bem lembra ELIVAL DA SILVA RAMOS, para quem:

“A Constituição outorgada por Getúlio Vargas em 10 de novembro de 1937 é, sem sombra de dúvida, a que menor estima angariou entre os estudiosos do direito constitucional brasileiro. Consubstancia a referida Carta um eloqüente exemplo da anomalia que Karl Lowenstein alcunhou de Constituição semântica, que poderíamos, também, com esteio no referido autor denominar de Constituição-disfarce. Com efeito, aproveitando-se do acirramento dos conflitos ideológicos internos e diante de um quadro de grave instabilidade no plano internacional, o Presidente Vargas fulminou, de uma só penada, a Constituição de 1934 e a expectativa de normalização democrática que a sua promulgação gerara. Implantou-se um sistema político autoritário (o Estado Novo), de viés tecno-burocrático, mas que, na verdade, acabou por se notabilizar pelo personalismo carismático do caudilho gaucho."

No plano do controle de constitucionalidade, ficou mantida a fiscalização difusa, incidental e repressiva ou sucessiva.

A representação interventiva não foi albergada pela Constituição de 1937, nem a faculdade de o Senado Federal suspender a lei declarada inconstitucional pelo Supremo Tribunal Federal.

O parágrafo único do artigo 96 da Carta de 37 (cujo caput trazia a exigência de observação do princípio da reserva de plenário para a declaração de inconstitucionalidade) continha uma estranha inovação, a permitir, no caso de ser declarada a inconstitucionalidade de uma lei que, a juízo do Presidente da República, fosse necessária ao bem-estar do povo, à promoção ou defesa de interesse nacional de alta monta, que o próprio Presidente a submetesse novamente ao exame do Parlamento: se este a confirmasse por dois terços de votos de cada uma das Câmaras, ficaria sem efeito a decisão do Tribunal.

O voto de dois terços do Congresso poderia retirar os efeitos da

${ }^{137}$ RAMOS, Elival da Silva. Perspectivas de evolução do controle de constitucionalidade no Brasil. 2005, 466 f., tese (provimento de cargo de professor titular), Universidade de São Paulo, Faculdade de Direito, Departamento de Direito do Estado - Direito Constitucional, São Paulo, 2005, p. 188. 
decisão do Supremo Tribunal Federal e transformar, assim, a lei inconstitucional em constitucional.

O referido dispositivo somente foi revogado pela Lei Constitucional $\mathrm{n}^{0}$ 18, de 11 de dezembro de 1945, na esteira do processo de abertura democrática do pós-guerra.

Na Carta de 1946, o controle difuso foi mantido, em seus contornos iniciais. O artigo 101, III, alínea $a$, atribuía ao Supremo Tribunal Federal a competência de julgar, em recurso extraordinário, as causas decididas em única ou última instância por outros tribunais ou juízes “quando a decisão for contrária a dispositivos dessa Constituição ou à letra de tratado ou lei federal”.

Foi reinstituída a competência do Senado Federal de suspender a execução de lei ou decreto declarados inconstitucionais e mantida a exigência do voto da maioria absoluta dos membros dos tribunais para a declaração de inconstitucionalidade.

A representação interventiva é reinserida, mas com rito distinto daquele da Constituição de 1934. Na Constituição de 1946, a representação interventiva tem a natureza de fiscalização principal de constitucionalidade, voltada a resolver um conflito federativo. Sua decisão produzia, portanto, efeitos concretos e erga omnes. Tratava-se, assim, de fiscalização principal e concreta de constitucionalidade. ${ }^{138}$

O controle abstrato de constitucionalidade, de inspiração europeia, na esteira das ideias de HANS KELSEN, foi implantado no Brasil através da Emenda Constitucional no 16, de 26 de novembro de 1965, à Constituição de 1946.

\footnotetext{
${ }^{138}$ CLÉMERSON MERLIN CLÈVE apontando as diferenças entre a ação direta interventiva e a representação de inconstitucionalidade afirma que: "A representação interventiva implica uma fiscalização concreta de constitucionalidade, embora realizada em sede de ação direta; presta-se exatamente para a solução de um conflito federativo. Com a representação genérica, ao contrário, manifesta-se modo de fiscalização abstrata de constitucionalidade, já porque em semelhante situação estará em jogo a compatibilidade, em abstrato (em tese), de um dispositivo normativo infraconstitucional contrastado com a Lei Fundamental da República.” In: CLÈVE, Clémerson Merlin. A Fiscalização abstrata de constitucionalidade no direito brasileiro. São Paulo, Revista dos Tribunais, 2000, p. 89.
} 
Referida emenda constitucional conferiu ao Supremo Tribunal Federal a competência originária para apreciar “a representação contra inconstitucionalidade de lei ou ato de natureza normativa, federal ou estadual, encaminhada pelo Procurador-Geral da República”. (art. 101, I, $k$ ).

A representação de inconstitucionalidade era verdadeiro instrumento do controle abstrato de normas, apto à verificação da inconstitucionalidade em tese de lei ou ato normativo.

O calcanhar de Aquiles do sistema instituído pela Emenda Constitucional $\mathrm{n}^{0} 16$ à Constituição de 1946 residia no fato de a legitimidade ativa para a propositura da representação de inconstitucionalidade ter sido conferida exclusivamente ao Procurador-Geral da República.

Com esta restrição, e diante do fato de o Procurador-Geral da República ser cargo de livre nomeação e exoneração pelo Presidente da República, fica claro que a representação de inconstitucionalidade só era proposta quando se voltava à proteção dos interesses do Chefe do Poder Executivo federal, como bem notado por FERREIRA FILHO. ${ }^{139}$

A Constituição de 1967 teve como tônica fortalecer os poderes do Presidente da República.

O controle difuso de constitucionalidade não foi objeto de modificações significativas, continuando a ser a via do recurso extraordinário o meio de acesso ao Supremo Tribunal Federal (art. 114, III, alíneas $a, b$ e $c$ ).

Na representação interventiva, a competência para suspender a execução do ato normativo foi transferida do Congresso Nacional para o Presidente da

${ }^{139}$ FERREIRA FILHO, Manuel Gonçalves. O Sistema Constitucional e as Recentes Inovações no Controle de Constitucionalidade: Leis $\mathrm{n}^{\circ}$ 9.868, de 10 de Novembro e $\mathrm{n}^{\circ}$ 9.882, de 3 de dezembro de 1989, Revista de Direito Administrativo. Rio de Janeiro, 220: 1-17, abr./jun. 2000, p. 8. 
República, por força do disposto no $\S 2^{\circ}$ do artigo 11, tratando-se aí, contudo, ao que tudo indica, de competência vinculada.

Manteve a Constituição o caráter híbrido do controle de constitucionalidade, prevendo, ao lado do controle incidental, a possibilidade de ajuizamento de ação direta genérica de inconstitucionalidade, controle principal, a cargo do ProcuradorGeral da República, nos moldes da Emenda nº 16 à Carta de 1946.

Foi, contudo, subtraída a possibilidade de os Estados-membros instituírem ação direta genérica perante seus tribunais de justiça, em virtude de a nova Constituição não possuir previsão autorizativa nesse sentido.

Dessa forma, houve dúvida a respeito da possibilidade, ou não, de os Estados-membros criarem sistema próprio de controle de constitucionalidade.

Algumas Constituições estaduais, como a dos estados de São Paulo e do Paraná, instituíram mecanismos de controle abstrato de constitucionalidade.

A Constituição do Estado de São Paulo previa a competência do Procurador-Geral do Estado (chefe advocacia pública do Estado) para representar ao Tribunal de Justiça (art. 54, I, e) sobre a inconstitucionalidade de leis ou atos normativos estaduais e municipais, por determinação do Governador ou solicitação do Prefeito ou Presidente da Câmara interessados (art. 51, § $1^{\circ}$ ).

A constitucionalidade desses dispositivos foi levantada na Representação de Inconstitucionalidade $\mathrm{n}^{\circ}$ 261.928, em que o Procurador-Geral do Estado representava a inconstitucionalidade de uma lei do Município de São Paulo (Lei municipal $n^{\circ}$ 8.550, de 31 de março de 1977).

O Procurador-Geral de Justiça, Dr. GILBERTO QUINTANILHA RIBEIRO, ofereceu parecer sustentando que em nível estadual não haveria 
previsão de jurisdição preservadora da Constituição Federal, bem como que o ProcuradorGeral do Estado seria parte ilegítima para a propositura da ação.

A Procuradoria Geral do Estado impugnou as preliminares, juntando aos autos pareceres de ilustres juristas: ADA PELLEGRINI GRINOVER ${ }^{140}$, CELSO BASTOS $^{141}$, JOSÉ AFONSO DA SILVA ${ }^{142}$ e DALMO DE ABREU DALLARI ${ }^{143}$.

O Tribunal de Justiça de São Paulo, em sessão plenária de 09 de agosto de 1978, em V. Acórdão da lavra do Desembargador XAVIER HOMRICH, por votação unânime, conheceu da representação e rejeitou as preliminares, por entender que os Estado-membros, com fundamento na competência remanescente ou residual (C. F. 1969, art. 13, § $1^{\circ}$ ), poderiam editar suas próprias normas para disciplinar a ação direta de inconstitucionalidade.

Todavia, o Supremo Tribunal Federal, ao analisar a questão em recurso extraordinário, entendeu que o controle abstrato de constitucionalidade é excepcional e só é admitido nos casos expressamente indicados na Constituição Federal (RE 92.169 ${ }^{144}$ ).

Em 13 de dezembro de 1968, foi editado o Ato Institucional $n^{0}$ 5, que outorgava diversos poderes ao Presidente da República, como os de decretar o recesso do Congresso Nacional, das Assembleias Legislativas e das Câmaras de Vereadores, ficando, assim, o Presidente autorizado a legislar em todas as matérias e exercer as atribuições previstas nas Constituições ou na Lei Orgânica dos Municípios (art. 2º e seu parágrafo único). O artigo 3ํㅡㄹ do referido ato institucional atribuía ao Presidente da República a competência de,

${ }^{140}$ GRINOVER, Ada Pellegrini. A ação direta de controle da constitucionalidade na Constituição paulista. In: CENTRO DE ESTUDOS DA PROCURADORIA GERAL DO ESTADO DE SÃO PAULO. Ação direta de controle de constitucionalidade das leis municipais, em tese. Revista da Procuradoria Geral do Estado de São Paulo. São Paulo, p. 51-66, 1979.

${ }^{141}$ BASTOS, Celso. O controle judicial da constitucionalidade das leis e atos normativos municipais. In: Ibidem, p. 67-77.

${ }^{142}$ SILVA, José Afonso da. Ação direta de declaração de inconstitucionalidade de lei municipal. In: Ibidem, p. 79-114.

${ }^{143}$ DALLARI, Dalmo de Abreu. Lei municipal inconstitucional. In: Ibidem, p. 115-131.

${ }^{144}$ In: MENDES, Gilmar Ferreira. Moreira Alves e o controle de constitucionalidade no Brasil. São Paulo, Celso Bastos Editor, 2000, p. 86. 
“no interesse nacional, [...] decretar a intervenção nos Estados e Municípios, sem as limitações previstas na Constituição”.

Verifica-se, assim, uma extrema centralização do poder, transformando a Constituição, mais uma vez, em um documento semântico, nos moldes da Carta de 1937.

A Emenda Constitucional $n^{\circ}$ 1, de 1969, por sua vez, manteve, no que tange ao controle de constitucionalidade, a estrutura prevista na Carta anterior. Permitiu, inovadoramente, a representação interventiva pelos Estados-membros, isto é, a prerrogativa de, nos moldes federais, provocar a fiscalização de constitucionalidade da lei municipal em face dos princípios constitucionais sensíveis da Constituição estadual.

Já a Emenda Constitucional nº 7, de 1977, atribuiu ao Supremo Tribunal Federal a competência para interpretar, com efeito vinculante, ato normativo federal ou estadual, outorgando ao Procurador-Geral da República a legitimidade para propor essa representação (art. 119, I, e). Previu também, essa emenda, a possibilidade de concessão de medida cautelar em sede de representação de inconstitucionalidade (art. 119, I, p).

Por fim, a Carta Federal de 1988, resultado da abertura democrática, trouxe profundas modificações no ordenamento jurídico pátrio e, igualmente, em sede de controle de constitucionalidade.

Ficou consagrado um sistema eclético de fiscalização de constitucionalidade, que prevê lado a lado o controle concreto e incidental, nos moldes da judicial review estadunidense, e a fiscalização principal e abstrata, exercida por meio de ação direta (voltada à verificação de inconstitucionalidade por ação e omissão: CF, art. 102, I, a, e art. 103, § $2^{\circ}$ ), prevendo-se, outrossim, a instituição de mecanismo voltado à sanção pelo descumprimento de preceito fundamental (CF, art. 102, § $1^{\circ}$ ).

As mais relevantes características do modelo de 1988 são as 
seguintes: (i) a legitimação para a propositura da ação direta de inconstitucionalidade, que era exclusiva do Procurador-Geral da República, foi consideravelmente ampliada, reconhecendose o seu elevado significado democrático (art. 103, I a IX); (ii) tornou-se obrigatória a manifestação do Procurador-Geral da República nas ações diretas de inconstitucionalidade (art. 103, § 1ำ; (iii) criou-se a figura do Advogado-Geral da União, a quem cabe a representação judicial e consultoria da União e, em sede de controle abstrato de constitucionalidade, a defesa do ato ou texto impugnado (art. 103, § 3ํ); (iv) criou-se a ação direta de inconstitucionalidade por omissão (art. 103, § 2º ) e o mandado de injunção (art. 5-o, LXXI); (v) criou-se um mecanismo destinado à arguição de descumprimento de preceito fundamental decorrente da Constituição (art. 102, parágrafo único, regulamentado, posteriormente, pela Lei no 9.882/99); (vi) manteve-se a competência do Senado Federal de retirar a eficácia de lei ou ato normativo declarado inconstitucional por decisão definitiva do Supremo Tribunal Federal (art. 52, X); (vii) reconheceu-se expressamente a possibilidade de os Estados-membros instituírem representação de inconstitucionalidade de leis ou atos normativos estaduais ou municipais em face da Carta Estadual (art. 125, § 2º).

A Emenda Constitucional $\mathrm{n}^{\circ}$ 3, de 1993, conferiu nova redação aos arts. 102 e 103 da Constituição, criando a ação declaratória de constitucionalidade de lei ou ato normativo federal, de competência originária do Supremo Tribunal Federal. Atribuiu, igualmente, às decisões definitivas de mérito, proferidas nas ações declaratórias de constitucionalidade, eficácia contra todos e efeito vinculante, relativamente aos demais órgãos do Poder Judiciário e do Poder Executivo.

A Emenda Constitucional $\mathrm{n}^{\circ}$ 45, de 8 de dezembro de 2004, alterou novamente o sistema de controle de constitucionalidade. A nova redação conferida ao $\S 2^{\circ}$ do artigo 102 atribuiu efeitos vinculantes às decisões definitivas de mérito proferidas nas ações diretas de inconstitucionalidade e nas ações declaratórias de constitucionalidade em relação aos demais órgãos do Poder Judiciário e à administração pública direta e indireta, nas esferas federal, estadual e municipal, nos moldes anteriormente conferidos à ação declaratória de constitucionalidade e conforme previsão já existente, no artigo 23, parágrafo único, da Lei $n^{\circ} 9.868 / 99$. 
O rol de legitimados para a propositura de ação declaratória de constitucionalidade foi ampliado, igualando-se àquele referente aos legitimados para a propositura de ação direta de inconstitucionalidade (CF, art. 103, caput). ${ }^{145}$

Também foi corrigida imperfeição formal que havia na lista de legitimados para a propositura de ação direta de inconstitucionalidade, na qual não figuravam a Mesa Diretora da Câmara Legislativa e o Governador do Distrito Federal, que passaram a constar expressamente do rol, ao lado das Mesas das Assembleias Legislativas e dos Governadores de Estado, entre os legitimados para propor essas ações (CF, art. 103, IV e V, respectivamente).

São esses, em linhas generalíssimas (dentro do objetivo do presente trabalho), os contornos do controle de constitucionalidade no Brasil. Fixados esses pontos, é possível avançar para o exame dos princípios processuais aplicáveis ao controle abstrato de constitucionalidade.

145 “Art. 103. Podem propor ação a direta de inconstitucionalidade e a ação declaratória de constitucionalidade: [...]". 


\section{Os Princípios Processuais e o Controle Abstrato de Normas}

\subsection{Os princípios processuais}

A relevância dos princípios constitucionais sobre a ordem processual é enfaticamente enunciada por DINAMARCO, para quem todo o conhecimento só é verdadeiramente científico quando tem fundamento nos princípios que o regem, pois "sem esta consciência, há o grande risco de perder a necessária coerência unitária entre os conceitos exarados e jamais ter-se segurança quanto ao acerto e boa qualidade dos resultados das investigações”. 146

\section{ARAÚJO CINTRA, GRINOVER e DINAMARCO expõem que} os princípios processuais são o resultado de uma operação de síntese crítica realizada pela ciência processual moderna, no sentido de encontrar preceitos fundamentais que dariam forma e caráter aos sistemas processuais. ${ }^{147}$

Pode-se afirmar que os princípios são vetores fundamentais em quaisquer sistemas, sendo certo que são eles que conferem ao conhecimento o seu caráter científico. São responsáveis por dar coerência ao sistema e organizam o conhecimento. ${ }^{148}$

Segundo LALANDE, o termo princípio possui o seguinte significado:

\footnotetext{
146 DINAMARCO, Cândido Rangel. Instituições de direito processual civil, v. I. $6^{\text {a }}$ ed., São Paulo, Malheiros, 2009, p. 196.

147 ARAÚJO CINTRA, Antonio Carlos; GRINOVER, Ada Pellegrini; DINAMARCO, Cândido Rangel. Teoria Geral do Processo. 25ª edição, São Paulo, Saraiva, 2009, p. 56.

148 "É sabido que se considera ciência aquele ramo de estudos que é informado por princípios. Estes, portanto, é que dão natureza de ciência a determinada matéria. Com o advento da obra clássica de Von Bülow, o processo foi elevado à categoria de ciência, autônoma e independente do direito civil, em conseqüência do tratamento principiológico que lhe foi dedicado pelo jurista alemão”. In: NERY JUNIOR, Nelson. Princípios do processo civil na Constituição Federal. 9a ed., São Paulo, Revista dos Tribunais, 2009, p. 49.
} 
“Começo, ponto de partida. 'Princípio é sinônimo de começo; e foi de início utilizado com esta significação; mas, em seguida, por força do uso, foi utilizado maquinalmente, por hábito e sem lhe atribuir idéias.' CONDILLAC, Lógica, II, cap. VI. Esta palavra emprega-se sobretudo por metáfora e quando se trata de uma ordem ideal mais do que de uma sucessão real. É uma das mais freqüentes na linguagem filosófica.”149

Já no sentido normativo, o termo teria a seguinte acepção:

"3”: No sentido normativo: E. Regra ou norma de ação claramente representada ao espírito, enunciada por uma fórmula. 'Os princípios da arte.' 'Proceder por princípios.' 'Todas as religiões admitiram o valor e a eficácia prática dos bons princípios, das doutrinas verdadeiras, sem negar com isso a influência do coração e da vontade.' FOUILLÉE, La pensée ..., p. 41. 'Em princípio' diz-se do que deve ser, conforme uma norma geral (mas anuncia de ordinário que se vai opor a essa norma algumas exceções justificadas ou toleradas)." 150

A definição do que sejam princípios, contudo, pode variar sensivelmente segundo o recorte doutrinário que lhes é dado. Vejam-se as seguintes abordagens a título de ilustração.

\section{GERALDO ATALIBA informa-nos que:}

"Os princípios são as linhas mestras, os grandes nortes, as diretrizes magnas do sistema jurídico. Apontam os rumos a serem seguidos por toda a sociedade e obrigatoriamente perseguidos pelos órgãos do governo (poderes constituídos).

Eles expressam a substância última do querer popular, seus objetivos e desígnios, as linhas mestras da legislação, da administração e da jurisdição. Por estas não podem ser contrariados; têm que ser prestigiados até as últimas conseqüências.

$[\ldots]$

Por isso, Juan Manuel Terán compara o princípio ao alicerce de um edifício, já que suporta o sistema e lhe dá consistência”. ${ }^{151}$

Em lição muito festejada, CELSO ANTÔNIO BANDEIRA DE

MELLO apresenta a seguinte definição para princípio:

\footnotetext{
${ }^{149}$ LALANDE, André. Vocabulário técnico e crítico da filosofia. São Paulo, Martins Fontes, 1993, p. 860.

${ }^{150}$ Ibidem, p. 861.

${ }^{151}$ ATALIBA, Geraldo. República e Constituição. 2a ed., São Paulo, Malheiros, 2004, p. 34.
} 
"Princípio - já averbamos alhures - é, por definição, mandamento nuclear de um sistema, verdadeiro alicerce dele, disposição fundamental que se irradia sobre diferentes normas compondo-lhes o espírito e servindo de critério para sua exata compreensão e inteligência exatamente por definir a lógica e a racionalidade do sistema normativo, no que lhe confere a tônica e lhe dá sentido harmônico. É o conhecimento dos princípios que preside a intelecção das diferentes partes componentes do todo unitário que há por nome sistema jurídico positivo.”152

\title{
Na visão de CELSO RIBEIRO BASTOS e SAMANTHA
}

\section{MEYER-PFLUG:}

\begin{abstract}
“Os princípios, ao contrário das meras regras, em virtude do seu alto grau de abstração e generalidade, não possuem este aspecto funcional -qual seja, o de incidir diretamente sobre as situações que objetivam regular. As regras diferenciam-se dos princípios, principalmente, em virtude do alto grau de abstração que estes últimos possuem. É dizer, os princípios têm por traço característico o fato de abarcarem um sem-número de situações. São genéricos e abstratos. Já as regras incidem diretamente sobre a matéria que regulam. Note-se que, tendo em vista o alto grau de abstração dos princípios, estes acabam por requerer medidas de concentração para serem aplicados ao caso concreto. Já com as regras isso não ocorre, pois as mesmas incidem diretamente na situação concreta." 153
\end{abstract}

A evidenciar o caráter de vetor interpretativo dos princípios, esclarece, ainda, CELSO RIBEIRO BASTOS que:

\begin{abstract}
"O princípio, ainda quando adotado de forma expressa pelo texto normativo, nem sempre está voltado para ser aplicado na prática, em casos concretos, mas se dirige precipuamente para resolver problemas interpretativos.

Podemos dizer que os princípios, embora percam em concretude, ganham em abrangência. Acabam por ser concretizados numa série de normas infraconstitucionais, que dão aplicação àquele princípio. Isto não significa, como querem alguns, que a existência dessas normas subconstitucionais acabem por interferir na própria aplicação do princípio, subvertendo-se a superioridade constitucional. Na verdade, estas leis integradoras só vicejam
\end{abstract}

\footnotetext{
152 BANDEIRA DE MELLO, Celso Antônio. Curso de direito administrativo. 24ª ed., São Paulo, Malheiros, 2007, p. 932-933.

153 BASTOS, Celso Ribeiro; MEYER-PFLUG, Samantha. Desenvolvimento e Atualização das Normas Constitucionais. In: SILVA, Virgílio Afonso da. (org.) Interpretação Constitucional. $1^{\mathrm{a}}$ ed., $2^{\mathrm{a}}$ tiragem, , São Paulo, Malheiros, 2005, p. 152.
} 
na medida em que estejam em conformidade com o princípio, e não o contrário." 154

Já as propostas de DWORKIN ${ }^{155}$ e de ALEXY ${ }^{156}$ apontam para outro vetor, voltado à diferenciação entre princípios e regras.

Segundo DWORKIN, a diferença entre princípios e regras seria de natureza lógica. As regras seriam aplicáveis por meio de uma fórmula de tudo-ou-nada: ou são aplicáveis integralmente, ou não são aplicáveis, sendo certo que a aplicação de uma regra exclui a incidência das demais. ${ }^{157}$ Os princípios, por outro lado, além dessa dimensão de validade, possuiriam outra, a de peso, a ser utilizada no caso de colisão de princípios, voltada à solução dos hard cases. Nesta hipótese, é necessário verificar, examinando o caso concreto, qual o princípio mais importante, de maior peso, que será utilizado para solucionar a controvérsia. $^{158}$

A formulação de ALEXY assemelha-se à de DWORKIN quanto ao fato de a distinção entre regras e princípios não se basear em critérios como a generalidade e especialidade da norma, mas sim em uma diferença qualitativa. Mas, para ALEXY, os princípios são mandamentos de otimização, isto é, "são normas que ordenam que algo seja realizado na maior medida possível dentro das possibilidades jurídicas e fáticas existentes”. ${ }^{159}$

154 BASTOS, Celso Ribeiro. Peculiaridades Justificantes de uma Hermenêutica Constitucional, Cadernos de Direito Constitucional e Ciência Política. São Paulo, Revista dos Tribunais, ano 5, $n^{\circ}$ 21, outubro-dezembro, 1997, p. 44.

${ }^{155}$ Veja-se, por exemplo: DWORKIN, Ronald. Uma questão de princípio. São Paulo, Martins Fontes, 2005, e Idem. Levando os Direitos a Sério. São Paulo, Martins Fontes, 2007.

${ }^{156}$ ALEXY, Robert. Teoria dos Direitos Fundamentais. tradução Virgílio Afonso da Silva, São Paulo, Malheiros, 2008.

${ }^{157}$ DWORKIN, Ronald. Levando os Direitos a Sério. São Paulo, Martins Fontes, 2007, p. 39, do qual se extrai o seguinte trecho: "Dados os fatos que uma regra estipula, então ou a regra é válida, e neste caso a resposta que ela fornece deve ser aceita, ou não é válida, e neste caso contribui para a decisão.”

158 "Essa primeira diferença entre regras e princípios traz consigo outra. Os princípios possuem uma dimensão que as regras não têm - a dimensão de peso ou importância. Quando os princípios se intercruzam (por exemplo, a política de proteção aos compradores de automóveis se opõe aos princípios de liberdade de contrato), aquele que vai resolver o conflito tem de levar em conta a força relativa de cada um. Esta não pode ser, por certo, uma mensuração exata e o julgamento que determina que um princípio ou uma política particular é mais importante que outra freqüentemente será objeto de controvérsia. Não obstante, essa dimensão é uma parte integrante do conceito de um princípio, de modo que faz sentido perguntar que peso ele tem ou quão importante ele é.” In Ibidem, p. 42-43.

159 ALEXY, Robert. Teoria dos Direitos Fundamentais. tradução Virgílio Afonso da Silva, São Paulo, Malheiros, 2008, p. 90. 
Enquanto o conflito entre regras "somente pode ser solucionado se se introduz, em uma das regras, uma cláusula de exceção que elimine o conflito, ou se pelo menos uma das regras for declarada inválida” 160 , as colisões entre princípios devem, segundo o seu entender, ser solucionadas de forma totalmente diversa:

"Se princípios colidem - o que ocorre, por exemplo, quando algo é proibido de acordo com um princípio e, de acordo com o outro, permitido -, um dos princípios terá de ceder. Isso não significa, contudo, nem que o princípio cedente deva ser declarado inválido, nem que nele deverá ser introduzida uma cláusula de exceção". ${ }^{161}$

Dessa forma, a colisão entre princípios só poderia ser solucionada às luzes do caso concreto, pois somente mediante a sua análise pode-se verificar qual princípio tem precedência, ou seja, um peso maior, para aquela dada situação. Por isso se diz que a colisão entre princípios deve ser solucionada pelo sopesamento entre eles. ${ }^{162}$

Esta diferenciação, por outro lado, não está isenta de críticas, como se pode verificar pelo exame das colocações de HUMBERTO ÁVILA, a sugerir uma abordagem distinta, segundo a qual as normas jurídicas podem ser classificadas em princípios, regras e postulados e sustentando que uma determinada norma pode se caracterizar ora como princípio, ora como regra, ora como postulado. ${ }^{163}$

${ }^{160}$ ALEXY, Robert. Teoria dos Direitos Fundamentais. tradução Virgílio Afonso da Silva, São Paulo, Malheiros, 2008, p. 92.

${ }^{161}$ Ibidem, p. 93.

${ }^{162}$ Segundo ALEXY: “A solução para essa colisão consiste no estabelecimento de uma relação de precedência condicionada entre os princípios, com base nas circunstâncias do caso concreto. Levando-se em consideração o caso concreto, o estabelecimento de relações de precedência condicionadas consiste na fixação de condições sob as quais um princípio tem precedência em face do outro. Sob outras condições, é possível que a questão da precedência seja resolvida de forma contrária”. In: Ibidem, p. 96.

163 "Viraram lugar-comum afirmações, feitas em tom categórico, a respeito da distinção entre princípios e regras. Normas ou são princípios ou são regras. As regras não precisam nem podem ser objeto de ponderação; os princípios precisam e devem ser ponderados. As regras instituem deveres definitivos, independentes das possibilidades fáticas e normativas; os princípios instituem deveres preliminares, dependentes das possibilidades fáticas e normativas. Quando duas regras colidem, uma das duas é inválida, ou deve ser aberta uma exceção a uma delas par superar o conflito. Quando dois princípios colidem, os dois ultrapassam o conflito mantendo sua validade, devendo o aplicador decidir qual deles possui maior peso.

A análise dessas afirmações semeia, porém, algumas dúvidas. Será mesmo que todas as espécies normativas comportam-se como princípios ou regras? Será mesmo que as regras não podem ser objeto de ponderação? Será mesmo que o conflito entre regras só se resolve com a invalidade de uma delas ou com a abertura de uma 
No campo específico do Direito Processual, identificando os princípios como normas dotadas de alto grau de generalidade, a consubstanciar o ponto de partida e a coluna externa de apoio de uma ciência, DINAMARCO distingue-os de inúmeras regras responsáveis pela boa ordem do processo e correto encaminhamento de suas conclusões, mas que não se qualificam como princípios. ${ }^{164}$

Dentre essas regras, cita o ilustre processualista como falsos princípios, extraídos da doutrina italiana e acatados prestigiosamente pela brasileira, os princípios econômico, lógico, jurídico e político. ${ }^{165}$ Enumera, ainda, outras regras técnicas, desenvolvidas ao longo de séculos e da experiência acumulada, que, embora de grande importância e prestígio, a rigor não se configurariam como princípios, embora costumeiramente conhecidas como tais. Seriam os seguintes: o princípio da demanda (CPC, art. $2^{\circ}$ e art. 262); o princípio da correlação entre provimento e demanda (CPC, art. 128 e art. 560); o princípio do livre convencimento (CPC, art. 131, combinado com o art. 458, II); o princípio da oralidade; o princípio dispositivo; o princípio da lealdade; o princípio da instrumentalidade das formas etc. ${ }^{166}$

Arremata o ilustre processualista afirmando que, embora tais regras não possam ser consideradas efetivamente princípios de direito processual, pode-se continuar falando em princípios nestes casos, com vistas a evitar inúteis discrepâncias com a doutrina em geral, apenas com a ressalva de que não têm todo o caráter de generalidade de que

exceção a uma delas?”. In ÁVILA, Humberto. Teoria dos Princípios: da definição à aplicação dos princípios jurídicos, $7^{\mathrm{a}}$ ed., São Paulo, Malheiros, 2007, p. 26.

${ }_{164}$ DINAMARCO, Cândido Rangel. Instituições de direito processual civil, v. I. $6^{a}$ ed., São Paulo, Malheiros, 2009, p. 200. Quanto a este ponto, DINAMARCO, opus cit, aduz que: "não se qualificam com princípios porque têm lugar no interior do sistema e não atuam como pilares sobre os quais este se apóia (estes, sim, são os verdadeiros princípios, especialmente os de índole político-constitucional)”.

165 “a) princípio econômico, voltado à produção do melhor resultado desejável com o menor dispêndio possível de recursos; b) princípio lógico, que aconselha a seleção de meios eficazes à descoberta da verdade e das soluções corretas, evitando erros; c) princípio jurídico, que postula a igualdade no processo e a fidelidade dos julgamentos ao direito substancial; d) princípio político, dirigido ao binômio representado pelo máximo possível de garantia social com o mínimo de sacrifício pessoal”. In: Ibidem, p. 200-201.

${ }^{166}$ Ibidem, p. 201. 
são dotados os princípios de origem político-constitucional, não podendo, por isso, ser denominados de princípios gerais. ${ }^{167}$

Dessa forma, percebe-se que o enfoque ortodoxo em qualquer das teorias que buscam asseverar a natureza dos princípios afastaria a possibilidade de se tratarem como princípios processuais diversas regras reconhecidas pela nomenclatura de princípios e costumeiramente aplicadas pela doutrina e jurisprudência nacionais há muito tempo.

O princípio do contraditório, por exemplo, de fundamental importância para a doutrina processual e cuja previsão encontra-se no seio da própria Constituição (CF, art. 5, $\mathrm{LV}$ ), pode ser visto apenas como uma regra, se entendido como a exigência de ciência bilateral dos atos e termos de processo e possibilidade (faculdade) de reação. Todavia, por outro lado, o contraditório pode ser entendido como um pressuposto necessário ao exercício do poder estatal, de modo a exigir que a decisão estatal seja precedida da possibilidade de as partes se manifestarem acerca da matéria ali tratada. Neste sentido, revela-se o contraditório como verdadeiro princípio que se volta à garantia do pluralismo e do próprio princípio democrático (vejam-se os comentários específicos acerca do princípio do contraditório no item próprio, infra).

O mesmo ocorreria em relação, v.g., aos princípios da irrecorribilidade e da irrescindibilidade das decisões do Supremo Tribunal Federal no controle abstrato de normas (Lei nº 9.868/99, art. 26) e com inúmeros outros princípios processuais.

\footnotetext{
167 "Falar em princípios como pontos de partida ou colunas externas de apoio de uma ciência, exclui realmente que tomem por princípios do direito processual essas regras que, sendo internas a ele, não têm a responsabilidade de atuar como elementos de sua ligação aos ramos maiores e ao tronco da grande árvore do conhecimento jurídico. Mesmo assim e com toda essa ressalva, podemos continuar falando em princípios nesses casos, para evitar inúteis discrepâncias verbais em face da doutrina em geral. Tenha-se sempre presente, contudo, que esses 'princípios' não têm todo o caráter de generalidade de que são dotados os de origem político-constitucional, pois referem-se apenas a algum setor do direito e da ciência processuais e não ao processo civil como um todo (por ex., o 'principio' do livre convencimento tem pertinência exclusivamente à disciplina da prova; o da oralidade, à forma dos atos no procedimento etc.). Jamais poderão ser considerados princípios gerais, portanto" In: DINAMARCO, Cândido Rangel. Instituições de direito processual civil, v. I, São Paulo, Malheiros, $6^{a}$ ed., São Paulo, Malheiros, 2009, p. 202.
} 
Por outro lado, pode-se constatar facilmente que a doutrina não apresenta um entendimento uníssono acerca dos elementos que caracterizariam os princípios. Pelo contrário, neste campo há grande celeuma. ${ }^{168}$

Assim, esclareço que pretendo, na presente dissertação, utilizar o termo princípio processual para designar as normas que possuam reconhecida importância no âmbito do Direito Processual e, em particular, no processo especial do controle abstrato de constitucionalidade. Entendo que a caracterização dessas normas como princípios é necessária, não só em decorrência do relevo que lhes tem sido atribuído pela experiência acumulada ao longo, não raro, de séculos, como também para acentuar-lhes o grau de primazia em face das demais normas processuais, a exigir a sua observância tanto na formulação legislativa das normas processuais (inclusive do controle abstrato, quando possível) como também em sua aplicação.

Feitas estas breves considerações acerca da extensão da utilização do termo princípios processuais na presente dissertação, passarei, em seguida, ao tema central do presente estudo.

\subsection{Os princípios processuais e sua aplicação ao controle abstrato de leis e atos normativos}

Como visto no item anterior, a doutrina processual adota um número expressivo de princípios que informariam o processo.

\footnotetext{
${ }^{168}$ Após expor a conceituação de princípios nas obras de ROBERT ALEXY, RONALD DWORKIN, LUIS VIRGÍLIO AFONSO DA SILVA, LENIO LUIZ STRECK, CANOTILHO e JOSEF ESSER, NELSON NERY JUNIOR chega a conclusão semelhante: "Pela exposição do pensamento de apenas alguns teóricos do direito, verifica-se que não é uniforme o entendimento a respeito dos conceitos de norma, princípio, regra, direito e garantia”. In: NERY JÚNIOR, Nelson. Princípios do processo civil na Constituição Federal. 9a ed., São Paulo, Revista dos Tribunais, 2009, p. 34.
} 
Especificamente em relação ao controle de constitucionalidade de normas, CANOTILHO arrola cinco princípios que denomina “princípios gerais do processo constitucional”. Adverte que, embora todos os princípios que menciona sejam considerados princípios básicos de outras ordens processuais (em especial do processo civil), enfatiza a grande cautela que se deve tomar para a sua transferência para o âmbito do processo constitucional. São os seguintes princípios sugeridos por CANOTILHO: (i) princípio do pedido; (ii) princípio da instrução; (iii) princípio da congruência ou da adequação; (iv) princípio da individualização; (v) princípio do controle material. ${ }^{169}$

\section{CARLOS BLANCO DE MORAIS invoca os seguintes} princípios, aplicáveis ao que denomina de "tramitação contenciosa dos processos de fiscalização abstrata no direito processual constitucional”: (i) princípio da subsidiariedade tendencialmente circunscrita do Direito Processual Civil; (ii) autonomia do Direito Processual Constitucional; (iii) princípio do equilíbrio relativo entre os “sub-princípios” do dispositivo e do inquisitório, com preponderância do segundo; (iv) princípio do pedido; (v) princípio da não vinculação do tribunal à causa de pedir; (vi) princípio do contraditório; (vii) princípio do interesse processual; (viii) princípio do aperfeiçoamento de pedido regular. ${ }^{170}$

Já JORGE MIRANDA esclarece que, inobstante a "prevalência de princípios comuns a todas as formas de processo e decorrentes, desde logo, dos princípios cardeais da Constituição, os processos do Tribunal Constitucional assentam ainda em princípios específicos, impostos pela função de garantia e pela estrutura do órgão”. ${ }^{171}$ Esclarece, outrossim, que os mencionados princípios nem sempre coincidem ao se projetarem sobre a fiscalização de constitucionalidade abstrata. Assim, fazendo uma distinção entre princípios estruturantes e instrumentais, afirma que podem ser considerados estruturantes do Direito Processual Constitucional português os seguintes princípios: a) princípio da igualdade dos intervenientes processuais (das partes na fiscalização concreta); b) princípio do

\footnotetext{
${ }^{169}$ CANOTILHO, Joaquim José Gomes. Direito constitucional e teoria da Constituição. $7^{\mathrm{a}}$ ed., Coimbra, Almedina, 2003, p. 971-973.

${ }^{170}$ MORAIS, Carlos Blanco de. Justiça constitucional, t. II. Coimbra, Coimbra Editora, 2005, p. 503-510.

171 MIRANDA, Jorge. Manual de Direito Constitucional, t. VI: Inconstitucionalidade e garantia da Constituição. $3^{\text {a }}$ ed., Coimbra, Coimbra Editora, 2008, p. 64.
} 
contraditório (audiatur et altera pars) ou de que os intervenientes processuais devem gozar de igualdade de oportunidades para expor as suas razões, procurando convencer o Tribunal em dialética e recíproca fiscalização; c) princípio da legalidade dos atos do processo; d) princípio da fundamentação das decisões que não sejam de mero expediente (arts. 205. ${ }^{\circ}, \mathrm{n}^{\circ} 1$, e 282. ${ }^{\circ}, \mathrm{n}^{\circ}$ 4, da Constituição portuguesa). ${ }^{172}$

Por outro lado, como princípios instrumentais do Direito Processual Constitucional, MIRANDA invoca os seguintes: a) o princípio do pedido (art. 51. ${ }^{\circ}$, $n^{\circ} 5,1^{a}$ parte, da lei orgânica do Tribunal Constitucional) na dupla vertente de necessidade de iniciativa externa para abertura do processo e fixação do objeto do processo - a constitucionalidade da norma a apreciar - pelo pedido; b) o princípio do conhecimento oficioso do Direito (art. 204. ${ }^{\circ}$, da Constituição e arts. 51. ${ }^{\circ}, n^{\circ}$ 5, in fine, e $79 .^{\circ}$ da lei orgânica do Tribunal Constitucional português); c) o princípio da utilidade da decisão, em face da situação normativa que se verifique ou de sua relevância para situações da vida; d) o princípio da economia processual (arts. 64. ${ }^{\circ}, 74 .^{\circ}, 78 .^{\circ}, 78 .^{\circ}-A, 78 .^{\circ}-\mathrm{B}$ e 79. - A, da lei orgânica do Tribunal Constitucional português); e) o princípio da celeridade (art. $20 .^{\circ}, \mathrm{n}^{\mathrm{o}} 4,1^{\mathrm{a}}$ parte, da Constituição portuguesa e arts. $60 .^{\circ}$ e $65 .^{\circ}$, da lei orgânica); f) o princípio do processo escrito (arts. 52. ${ }^{\circ}, 54 .^{\circ}, 63 .^{\circ}$ e $79 .^{\circ}$ da lei orgânica do Tribunal Constitucional português); e g) o princípio da subsidiariedade do Direito Processual Civil (arts. 48..$^{\circ}$ 69. ${ }^{\circ}$ e $79 .^{\circ}$-B, da lei orgânica do Tribunal Constitucional português). ${ }^{173}$

Na doutrina nacional, JULIANO TAVEIRA BERNARDES, após examinar o caráter objetivo do processo de controle abstrato de constitucionalidade, em uma enumeração que afirma ser não taxativa, examina os seguintes princípios: (i) princípio da instrumentalidade do processo objetivo; (ii) princípio da acessibilidade limitada ao processo objetivo; (iii) princípio do interesse objetivamente considerado; (iv) princípio do pedido; (v) princípio da congruência; (vi) princípio da capacidade postulatória especial; (vii) princípio da abertura da causa de pedir; (viii) princípio da indisponibilidade; (ix) princípio do controle

172 MIRANDA, Jorge. Manual de Direito Constitucional, t. VI: Inconstitucionalidade e garantia da Constituição. 3ª ed., Coimbra, Coimbra Editora, 2008, p. 64.

${ }^{173}$ Ibidem, p. 64-65. 
material; (x) princípio da instrução oficiosa; (xi) princípio da publicidade; (xii) princípio da irrecorribilidade; e (xiii) princípio da irrescindibilidade.

Utilizarei, como critério metodológico para a análise dos princípios processuais e sua aplicabilidade ao controle abstrato de normas, a sua abordagem a partir da estrutura legal vigente no Brasil, na qual o controle de normas é disciplinado tanto pela Constituição Federal, como pelas Leis federais n ${ }^{0}$ 9.868/99 ${ }^{174}$ e 9.882/99. ${ }^{175}$ Assim, desenvolverei o estudo dos princípios processuais do controle abstrato por meio da análise sequencial dos artigos dos referidos diplomas legais.

\subsubsection{O princípio da especialidade do processo de controle abstrato de normas e o princípio da subsidiariedade da aplicação das normas do processo comum}

O controle abstrato de normas é previsto no próprio texto constitucional e assim deve ser em decorrência de o seu exercício excepcionar a aplicação do princípio da separação dos Poderes ${ }^{176}{ }^{177}$, pois a decisão que resulta da atuação da Corte,

\footnotetext{
${ }^{174}$ Dispõe sobre o processo e julgamento da ação direta de inconstitucionalidade e da ação declaratória de constitucionalidade perante o Supremo Tribunal Federal.

${ }^{175}$ Dispõe sobre o processo e julgamento da arguição de descumprimento de preceito fundamental, nos termos do $\S 1^{\circ}$, do art. 102 da Constituição Federal.

${ }^{176}$ Neste sentido, veja-se o entendimento de JORGE MIRANDA: “A fiscalização de constitucionalidade repugna, porque envolve a produção de actos por órgãos diversos em relação ao mesmo processo de criação legislativa, que todo deve caber a um órgão ou conjunto de órgãos naturais: o Parlamento. Numa acepção de mero alcance formal, um acto de fiscalização integrar-se-ia no desenvolvimento de uma competência constitucional, implícita ou explícita. Numa acepção material, pelo contrário, todo o processo legislativo recai sobre o Parlamento, não pode recair também, seja em que parte for, sobre os tribunais. Assim, como os órgãos legislativos não podem interferir no exercício da competência dos órgãos judiciais, assim estes não podem interferir no exercício da competência daqueles.

Tem-se concluído que, por detrás da teoria da separação dos poderes, tal como vem enunciada nos séculos XVIII e XIX, está uma visão puramente estática ou estatizante do mundo político, porquanto supõe uma crença metajurídica na perfeita coexistência dos três poderes, deste modo distintos e cindidos, e sobretudo porquanto abstrai do funcionamento do próprio Estado, que - a experiência mostra - requer uma permanente colaboração de todos os órgãos. Tudo de conduz a uma imagem de harmonia pré-estabelecida, sem a qual seria impensável a enaltecida separação.

Mas, justamente porque domina a tese da harmonia no interior do corpo do Estado, não devemos ligar apenas a ausência da garantia jurisdicional da Constituição a uma, mais ou menos esboçada, cisão na unidade do poder político e a um enclaustramento dos juízes, na sua específica função. Também se torna preciso ligá-la ainda ao
} 
como visto, muito se assemelha à do legislador, ainda que vista sob o prisma de legislação negativa, ou seja, da invalidação de normas.

Dessa forma, o texto constitucional original de 1988 instituiu o controle abstrato de constitucionalidade, atribuindo ao Supremo Tribunal Federal a competência originária para processar e julgar a ação direta de inconstitucionalidade de atos normativos federais ou estaduais (art. 102, I, a), a ação direta de inconstitucionalidade por omissão (art. 103, § $2^{\circ}$ ), a representação de inconstitucionalidade de leis ou atos normativos estaduais ou municipais em face das Constituições dos Estados-membros (cabendo aos próprios Estados instituírem-na, art. 125, § $2^{\circ}$ ) e a previsão de criação, por lei, da arguição de descumprimento de preceito fundamental (art. 102, parágrafo único da redação original, transformado em $\S 1^{\circ}$ pela $\left.\mathrm{EC} \mathrm{n}^{\circ} 3 / 93\right)$.

A Constituição de 1988 também dispõe acerca dos legitimados para a propositura da ação, em seu art. 103, caput, e circunscreve a criação da representação de inconstitucionalidade em âmbito estadual, impedindo que a legitimação para a propositura da ação seja conferida a apenas um órgão (art. 125, § $2^{\circ}$ ), de modo a evitar o monopólio do controle abstrato por apenas um legitimado, como ocorria no sistema anterior, que atribuía a legitimação para agir apenas ao Procurador-Geral da República.

Além disso, a própria Constituição Federal, a demonstrar a natureza especial do processo de controle abstrato, desenvolvido segundo rito próprio, previu

optimismo liberal já acenado: não é, ao fim e ao cabo, por confiar no seu modo de compreender o Estado, o melhor possível, que o liberalismo deixa alardeada a intangibilidade das normas?”. In: MIRANDA, Jorge. Contributo para uma Teoria da Inconstitucionalidade. Coimbra, Coimbra Editora, 1996, p. 45-46.

177 O Ministro MOREIRA ALVES, por ver no controle abstrato um meio excepcional de controle de constitucionalidade, entendeu que as constituições dos Estados não poderiam prever a competências dos tribunais locais para julgar ações diretas de leis municipais em face da Constituição federal. Asseverou o Ministro que: "a representação não interventiva de inconstitucionalidade é meio excepcional de controle de constitucionalidade. O meio normal é o da declaração incider tantum. Não houve sequer, com relação à exclusão das leis municipais a esse tipo de controle de constitucionalidade, omissão por inadvertência, a única que configura lacuna no ordenamento jurídico e que é suscetível de suprimento por via de aplicação de analogia, que, por isso mesmo, não é passível de ser usada com relação às normas excepcionais no que diz respeito aos casos não abarcados por elas”. In: Recurso Extraordinário nº 92.169/SP, Tribunal Pleno, Rel. Min. CUNHA PEIXOTO, RTJ 103/10851117, apud MENDES, Gilmar Ferreira. Moreira Alves e o controle de constitucionalidade no Brasil. São Paulo, Celso Bastos Editor, 2000, p. 562. 
em seu texto que o Procurador-Geral da República deverá ser previamente ouvido nas ações de inconstitucionalidade (art. 102, § $1^{\circ}$ ), a citação prévia do Advogado Geral da União, a quem incumbe a defesa da norma impugnada (art. 102, § $3^{\circ}$ ), e disciplinou as medidas a serem tomadas em decorrência da decisão que declara a inconstitucionalidade por omissão (art. 102, $\left.\S 2^{\circ}\right)$.

Atualmente, o processo e o julgamento das ações de controle abstrato de constitucionalidade estão previstos nas Leis federais $n^{\circ}$ 9.868/99 ${ }^{178}$ e 9.882/99 ${ }^{179}$.

Anteriormente à existência dessas leis, para julgamento das ações diretas de inconstitucionalidade era utilizado o processo destinado à regulamentação da ação direta interventiva (Lei ${ }^{\circ}$ 4.337, de $1^{\circ}$ de junho de 1964) e, principalmente, o Regimento Interno do Supremo Tribunal Federal.

A complementação das lacunas da lei, todavia, não era feita com fundamento nas normas de processo civil comum, mas, sim, mediante a observância do procedimento previsto no Regimento Interno do Supremo Tribunal Federal (arts. 169 a 175). É necessário ter em vista que a Constituição de 1967, com a redação conferida pela EC $\mathrm{n}^{\circ} 1$, de 1969, conferia ao Supremo Tribunal Federal a competência para elaborar seu Regimento Interno e, por meio dele, disciplinar “o processo e julgamento dos feitos de sua competência originária ou de recurso” (art. 120, parágrafo único, “c”, posteriormente modificado pela EC $\mathrm{n}^{\mathrm{o}} 7 / 77$, que realocou a matéria no $\S 3^{\circ}$, do art. $\left.119^{180}\right) .^{181}$

\footnotetext{
178 Dispõe sobre o processo e julgamento da ação direta de inconstitucionalidade e da ação declaratória de constitucionalidade perante o Supremo Tribunal Federal.

${ }^{179}$ Dispõe sobre o processo e julgamento da arguição de descumprimento de preceito fundamental, nos termos do $\S 1^{\circ}$, do art. 102 da Constituição Federal.

180 “Art. 119. Compete ao Supremo Tribunal Federal: [...]

$\S 3^{\circ} \mathrm{O}$ regimento interno estabelecerá: [...]

c) o processo e julgamento dos feitos de sua competência originária ou recursal e da argüição de relevância da questão federal”

${ }^{181}$ Neste sentido, veja-se o entendimento de FERREIRA FILHO: “Regimento Interno. As alíneas deste parágrafo estipulam o conteúdo mínimo do regimento interno. Evidentemente, poderá ele dispor sobre outras questões além das enumeradas nas referidas alíneas. Há uma diferença importantíssima a fazer, porém. Nas matérias indicadas nas alíneas, a competência para dispor, no regimento interno, sobre elas, vem da Constituição para o Supremo, diretamente, sem o intermediário que é a lei. Com referência a elas, a Constituição delegou ao Supremo verdadeiro poder de legislar, ara a sua regulamentação". In: FERREIRA FILHO, Manoel Gonçalves.

Comentários à Constituição brasileira. 4ª ed., São Paulo, Saraiva, 1983, p. 483. No mesmo sentido:
} 
No controle incidental ou concreto de constitucionalidade, como mencionado acima ( $\mathrm{n}^{\circ}$ 2.4.1), a questão de constitucionalidade é suscitada em um processo comum, em meio a um litígio entre partes, que não diz respeito especificamente à inconstitucionalidade da lei, que é arguida incidentalmente, como questão prejudicial ao conhecimento do mérito. Assim, no controle difuso, são aplicáveis as regras procedimentais do processo comum, previstas nos códigos de processo. ${ }^{182}$

No processo de controle abstrato, por outro lado, a inconstitucionalidade é o próprio objeto da ação que, por esta razão (a própria natureza do direito tutelado no processo) deve possuir um rito especial.

A especialidade do rito da ação direta de inconstitucionalidade tem sido abordada de longa data pela doutrina e jurisprudência nacionais.

BUZAID esclarece, acerca da ação direta interventiva, precursora da atual ação direta genérica, que:

"Cremos que essa é a única ação direta, que tem, como objeto principal, a declaração de inconstitucionalidade. E essa foi uma notável tentativa, feita no Brasil, de atribuir ao Poder Judiciário competência para resolver tal conflito de normas. Anteriormente, até as questões políticas podiam ser apreciadas pelos magistrados, mas sempre dentro dos limites de um pleito, fundado em ameaça ou ofensa a direito individual. A simples circunstância de uma lei ser inconstitucional não basta para justificar o ingresso perante o Poder Judiciário, pois a ninguém era lícito, uti civis, impugnar-lhe a

BERNARDES, Juliano Taveira. Controle abstrato de constitucionalidade: Elementos materiais e princípios processuais. São Paulo, Saraiva, 2004, p. 357, ao afirmar que, aprovado "em Sessão de 15-10-1980, o RISTF foi editado em período em que a Constituição vigente concedia à Corte competência legislativa para regular suas próprias atribuições. Por isso, a despeito de a atual Constituição não conter norma semelhante, o RISTF foi recepcionado com status de lei ordinária”.

${ }^{182}$ Como lembra CAPPELLETTI: "é um erro tradicional o de se ir à procura de um ou outro procedimento especial, como, por exemplo, o writ of habeas corpus ou, ainda, o writ of error ou o writ of certiorari, para servir de base à judicial review of legislation do sistema norte-americano: ao contrário, a 'regra fundamental' daquele sistema é que não existe qualquer tipo especial de procedimento - assim como não existe um órgão especial competente - para as questões constitucionais, as quais 'se deciden según surgen en cada caso determinado, cualquiera que sea la naturaleza de los derechos em cuestión, o de los recursos que promueven'”. In: CAPPELLETTI, Mauro. O Controle Judicial de Constitucionalidade das Leis no Direito Comparado, Rio Grande de Sul, Sérgio Fabris Editor, 1999, p. 86-87. 
validade; a propositura da ação deve fundar-se na ameaça a violação a direito subjetivo. A evolução do pensamento nacional não se interrompe com o advento da Lei $n^{\circ} 2.271$. Esta lei não confere ao Procurador-geral da República o poder de argüir inconstitucionalidade em tese, mas tão-só em hipótese, quando ela possa constituir fundamento para a intervenção.”183

\section{Segundo ELIVAL DA SILVA RAMOS:}

"Se o controle de constitucionalidade, sob qualquer modalidade configura a função de controle jurídico da atividade legislativa, isso fica ainda mais nítido ao se examinar o controle em via de ação direta genérica.

Com efeito, a utilização desse instrumento, como já dissemos, enseja, amiúde, a formação de um contencioso objetivo, onde a legitimação para agir é reconhecida abstrata e objetivamente, conectando-se o interesse que anima o autor diretamente com o interesse público no exercício da sobredita função de controle. Desse modo, 'fica sobremaneira esmaecida a presença de uma função jurisdicional clássica, de composição oficial de conflitos de interesse, para dar lugar à já referida função de controle jurídico do Poder Público, na espécie o Poder Legislativo’.,"184

Como informa GILMAR FERREIRA MENDES, em obra pioneira no Brasil sobre a natureza do controle de constitucionalidade:

“A representação de inconstitucionalidade, consagrada no art. 119, I, $l$, da Constituição de 1967/1969, constitui processo que não tem outro escopo, senão o de defesa da ordem fundamental contra atos com ela incompatíveis. Não se destina, pela sua própria índole, à proteção de situações individuais ou de relações subjetivas, mas visa, precipuamente, à defesa da ordem jurídica." 185

Quanto ao caráter objetivo do processo, MENDES traz a

experiência da doutrina e jurisprudência alemãs:

"Tem-se aqui, pois, o que a jurisprudência dos Tribunais Constitucionais costuma chamar de processo objetivo (objektives Verfahren), isto é, um processo sem sujeitos, destinado, pura e simplesmente, à defesa da Constituição (Verfassungsrechtsbewahrungsverfahren), que pressupõe a

${ }^{183}$ BUZAID, Alfredo. Da ação direta de declaração de inconstitucionalidade no direito brasileiro. São Paulo, Saraiva, 1958, p. 113-114.

${ }^{184}$ RAMOS, Elival da Silva. A Inconstitucionalidade das Leis: vício e sanção. São Paulo, Saraiva, 1994, p. 229-230.

${ }^{185}$ MENDES, Gilmar Ferreira. Controle de constitucionalidade: Aspectos jurídicos e políticos. São Paulo, Saraiva, 1990, p. 249-250. 
defesa de situações subjetivas. Nesse sentido, assentou o Budesverfassungsgericht que, no controle abstrato de normas, cuida-se, fundamentalmente, de um processo unilateral, não-contraditório, isto é, de um processo sem partes, no qual existe um requerente, mas inexiste requerido." ${ }^{186}$

Em outra obra, confirma o ilustre professor que os processos de controle abstrato de constitucionalidade têm natureza objetiva (objektives Verfahren), não conhecem partes (Verfahren ohne Beteiligte) e podem ser instaurados independentemente de um interesse jurídico específico. ${ }^{187} 188$

O Ministro CELSO DE MELLO ao enfocar a impossibilidade de aplicação da regra que prevê prazo recursal em dobro para a Fazenda Pública (CPC, art. 188) em ação direta de inconstitucionalidade, assevera a ideia do processo objetivo, bem como da inviabilidade de aplicação direta e sistemática das normas do processo comum. ${ }^{189}$

${ }^{186}$ MENDES, Gilmar Ferreira. Controle de constitucionalidade: Aspectos jurídicos e políticos. São Paulo, Saraiva, 1990, p. 250.

${ }^{187}$ Idem. Direitos fundamentais e controle de constitucionalidade. São Paulo, Saraiva, 2006, p. 320, onde cita, neste contexto, a lição de TRIEPEL: "No primeiro quartel do século passado, afirmava Triepel que os processos de controle de normas deveriam ser conhecidos como processos objetivos. Assim, sustentava ele, no conhecido Referat sobre a 'natureza e desenvolvimento da ação constitucional', que, quanto mais políticas fossem as questões submetidas à jurisdição constitucional, tanto mais adequada pareceria a adoção de um processo judicial totalmente diferenciado dos processos ordinários. Quanto menos se cogitar, nesse processo, de ação [...], de condenação, de cassação de atos estatais - dizia Triepel - mais facilmente poderão ser resolvidas, sob a forma judicial, as questões políticas, que são, igualmente, questões jurídicas.”

${ }^{188}$ Também em parecer oferecido na Representação nº 1.405/AC, perante o Supremo Tribunal Federal, GILMAR FERREIRA MENDES, então Procurador da República, explicitou os contornos do processo de controle concentrado, ainda sob a égide da Constituição de 1967/1969: "Vê-se, pois, que tal como concebido pelo constituinte e desenvolvido pelo Supremo Tribunal Federal, o controle abstrato de normas, previsto no art. 119, I, l, do Texto Magno, configura processo objetivo, não contraditório, destinado, exclusivamente, à defesa da ordem constitucional. 'O Procurador-Geral da República é o titular dessa representação - ressalta a Excelsa Corte apenas para o efeito de provocar, ou não' (AR N. 878, RTJ 94/58). O processo de controle abstrato de normas constitui, também entre nós, um autêntico processo sem partes (ein Verfahren ohne Beteiligte). (Cf., a propósito, Söhn, op. cit., p. 304; v. também, Embargos na Rp. 1.092, Rel. Min. Néri da Silveira, RETJ 117/921; Cf., especificamente, voto preliminar do Ministro Moreira Alves, RT 117/952)”. In: MENDES, Gilmar Ferreira. Moreira Alves e o controle de constitucionalidade no Brasil. São Paulo, Celso Bastos Editor, 2000, p. 191.

189 "Ninguém desconhece que o processo de fiscalização abstrata de constitucionalidade configura típico processo de caráter objetivo, destinado a viabilizar 'o julgamento, não de uma relação jurídica concreta, mas de validade de lei em tese [...]' Isso significa - admitido o perfil objetivo que tipifica a fiscalização abstrata de constitucionalidade (GILMAR FERREIRA MENDES, “Jurisdição Constitucional”, p. 129/130, 2ª ed., 1998, Saraiva) - que, em regra, não se deve reconhecer, como pauta usual de comportamento hermenêutico, a possibilidade de aplicação sistemática das normas concernentes aos processos de índole subjetiva, especialmente daquelas regras meramente legais que disciplinam a incidência de determinados institutos peculiares aos processos meramente subjetivos, vale dizer, àqueles processos em cujo âmbito se instauram controvérsias de natureza concreta e de caráter individual”. In: ADI 2995 AgR/PE - PERNAMBUCO- AGRAVO 
Analisando o sistema português de controle de constitucionalidade, que em muito se assemelha ao nosso, com a particularidade da existência, no além-mar, de um tribunal com feições mais próximas de um típico Tribunal ou Corte Constitucional, VITALINO CANAS enfoca as diferenças entre os processos de controle abstrato e os comuns ao afirmar que:

"Estes últimos têm por fim resolver lides ou conflitos intersubjectivos de interesses que se manifestem em concreto. E se não se quiser ficar preso no conceito, porventura demasiado rígido, de lide, pelo menos terá de se reconhecer que nesses processos vêm sempre envolvidos interesses subjectivos. Neles, o juiz ocupa a posição de entidade imparcial em relação aos interesses em conflito a propósito dos quais foi encarregue de averiguar qual deles o direito considera que em concreto deve prevalecer.

Diferentemente, os processos de fiscalização da constitucionalidade e da legalidade são processos objectivos, já que não visam o julgamento de lides ou até mesmo de simples controvérsias (embora por vezes haja controvérsia sobre a questão; isto não é, porém indispensável ou inevitável), mas sim de questões de constitucionalidade suscitadas em abstracto ou em concreto. O juiz constitucional não é imparcial em relação ao interesse que procura tutela directa. Ele acaba por ser tão interessado na satisfação do interesse objectivo da constitucionalidade e da legalidade, como qualquer dos outros sujeitos processuais." 190

$\mathrm{Na}$ obra em comento, CANAS analisa justamente a processualidade do processo de controle de constitucionalidade, sustentando que os princípios processuais a que está submetido o processo constitucional não são os mesmos que regem, por natureza, os processos que denomina de "jurisdicionais, motivo pelo qual o processo constitucional exigiria um corpo próprio de regras de processo”. ${ }^{191}$

O recurso às regras de processo civil, segundo a sua avaliação deve ser apenas subsidiário e só poderia ocorrer em duas circunstâncias: “quando não haja normas específicas para o processo constitucional; e quando as normas do processo civil se

REGIMENTAL NA AÇÃO DIRETA DE INCONSTITUCIONALIDADE, Relator: Min. CELSO DE MELLO. Julgamento: 31/10/2006. Publicação: DJ 08/11/2006, p. 27.

${ }^{190}$ CANAS, Vitalino. Os processos de fiscalização da constitucionalidade e da legalidade pelo Tribunal Constitucional - Natureza e princípios estruturantes. Coimbra, Coimbra Editora, 1986, p. 88.

${ }^{191}$ Ibidem, p. 88. 
adaptarem à natureza própria do processo constitucional”. ${ }^{192}$ Entendo que esta proposta se mostra perfeitamente aplicável no ordenamento brasileiro.

De fato, não se revela inviável a aplicação das normas de processo comum no processo objetivo, desde que feita com cautela e respeitando as especificidades do processo de controle abstrato. Em voto proferido na ADI 437-QO, na qual se debatia acerca da possibilidade de o autor aditar o pedido contido na inicial, decidiu o Ministro CELSO DE MELLO pela aplicação subsidiária das normas do Código de Processo Civil. Do seu voto, extrai-se o seguinte trecho:

"Com o ajuizamento da ação direta de inconstitucionalidade, instauram-se, perante o Supremo Tribunal Federal, relações processuais objetivas, cuja disciplina formal está definida no Regimento Interno desta Corte, a que se aplicam, subsidiariamente, as normas inscritas no Código de Processo Civil.

Não se revela, em princípio, inviável a redução da ação direta de inconstitucionalidade às categorias básicas existentes do processo civil, não obstante as nítidas diferenças existentes - e já proclamadas por esta própria Corte - entre o procedimento judicial comum e o processo de controle concentrado de constitucionalidade. A processualização da ação direta e das formas rituais que se lhe aplicam constitui, na realidade, até mesmo em obséquio à unidade fundamental do processo, um mínimo indispensável à própria disciplina da fiscalização abstrata dos atos normativos." 193

Assim, pode-se concluir que o processo de controle principal de constitucionalidade possui natureza especialíssima. Isso não impede, todavia, que sejam aplicadas, subsidiariamente, as regras do processo comum, quando não houver norma a regular a matéria; e quando as normas do processo comum se adaptarem às especificidades do processo objetivo. Quanto aos princípios processuais, como visto anteriormente, entendo devam ser aplicados ao processo objetivo sempre que não contrastarem com as regras e princípios específicos desta espécie de processo. Já os princípios constitucionais do processo (princípios da publicidade, da motivação das decisões, do contraditório e da reserva de

192 CANAS, Vitalino. Os processos de fiscalização da constitucionalidade e da legalidade pelo Tribunal Constitucional: Natureza e princípios estruturantes. Coimbra, Coimbra Editora, 1986, p. 89.

${ }_{193}$ ADI 437-QO, Rel. Ministro CELSO DE MELLO, Ementário nº 1692-1, D. J. de 19.02.93, Tribunal Pleno, grifos no original, grifos nossos. 
plenário, por exemplo) devem sempre ser observados, tanto no momento da conformação legislativa das regras específicas como na sua aplicação empírica pelos tribunais.

Por fim, pode-se fazer um rol, não exaustivo, das características processuais decorrentes da especialidade do processo de controle abstrato de normas:

1. Rito próprio, previsto nas Leis federais $n^{0} 9.868 / 99$ e $n^{0} 9.882 / 99$;

2. Processo objetivo, no qual inexistem partes, no sentido processual do termo (ou seja, dos sujeitos processuais que buscam a defesa em juízo de interesses parciais) e, portanto, inexistência de lide em seu conceito tradicional (conflito de interesses, qualificado por uma pretensão resistida);

3. Rol de legitimados ativos restrito e previsto constitucionalmente;

4. Impossibilidade de desistência do pedido [Lei federal $n^{0}$ 9.868/99, art. $5^{\circ}$ (ADI) e art. 16 (ADC)];

5. Impossibilidade de intervenção de terceiros, ressalvada a participação do amicus curiae [Lei federal $n^{\circ} 9.868 / 99$, art. $7^{\circ}$, caput e $\S 2^{\circ}(\mathrm{ADI})$ e art. 18 (ADC) e Lei federal $\mathrm{n}^{\circ} 9.882 / 99$, art. $6^{\circ}$, $\S \S 1^{\circ} \mathrm{e}$ $\left.2^{\circ}\right]$

6. Inaplicabilidade das normas do Código de Processo Civil sobre suspeição e impedimento ${ }^{194}$;

7. Inexistência de recurso contra a decisão de mérito proferida nestas ações, admitida apenas a oposição de embargos de declaração (Lei federal $n^{\circ}$ 9.868/99, art. 26 e Lei federal $n^{\circ}$ 9.882/99, art. 12) e ressalvada a hipótese de recursos contra as decisões dos Tribunais de Justiça estaduais;

\footnotetext{
${ }^{194}$ Na ADI 3741, o Ministro RICARDO LEWANDOWSKI sustentou a inaplicabilidade dos impedimentos e suspeições previstos na legislação processual civil ao processo do controle concentrado, em virtude de estes "restringirem-se exclusivamente aos processos subjetivos, ou seja, àqueles que envolvam interesses individuais e situações concretas", entendimento este consolidado na Súmula 72 do STF, que possui o seguinte teor: "No julgamento de questão constitucional, vinculada à decisão do Tribunal Superior Eleitoral, não estão impedidos os Ministros do Supremo Tribunal Federal que ali tenham funcionado no mesmo processo, ou no processo originário.”
} 
8. Inaplicabilidade das regras processuais que preveem prazos maiores para recursos (art. 188 do Código de Processo Civil);

9. Caráter retroativo impróprio das decisões proferidas nas ações de controle abstrato, com o efeito de retirar a lei do ordenamento jurídico desde o seu nascedouro e restituir a validade dos atos normativos revogados pela norma declarada inconstitucional (ineficácia revocatória da lei declarada inconstitucional que causa um aparente efeito repristinatório). 195196

Pretendo, a seguir, verificar a configuração que os conhecidos princípios processuais assumem quando aplicados no âmbito do controle abstrato de normas, bem como quais os princípios específicos que iluminam esta espécie de processo.

\subsubsection{O princípio do juiz natural e o princípio ou cláusula de reserva de plenário [Constituição Federal, art. $5^{\circ}$ e art. 97; Lei federal no 9.868/99, art. $1^{\circ}$ (ADI e ADC); e Lei federal $n^{0}$ 9.882/99, art. $1^{\circ}$ (ADPF)]}

A Constituição Federal de 1988 proíbe a existência de juízos ou tribunais de exceção (art. 5 XXXVII), bem como estipula que ninguém será processado nem sentenciado senão pela autoridade competente (art. 50, LIII). Nesses dispositivos se manifestam as duas faces do princípio do juiz natural.

O seu espectro de aplicação é amplo, incidindo não só nos processos penais, como também nos civis, administrativos e nos de natureza jurídicopolítica. ${ }^{197}$

\footnotetext{
195 vide notas nºs 130 e 131, supra.

${ }^{196}$ A retomada de eficácia da lei anterior é prevista na Lei federal $n^{\circ}$ 9.868/99, quando disciplina os efeitos da medida cautelar. $\mathrm{O} \S 2^{\circ}$, de seu art. 11 possui o seguinte teor: “A concessão da medida cautelar torna aplicável a legislação anterior acaso existente, salvo expressa manifestação em sentido contrário.”

197 Neste sentido, o entendimento de OLIVAR AUGUSTO ROBERTI CONEGLIAN: “Ao estabelecer que 'ninguém será processado nem sentenciado senão pela autoridade competente’, a Constituição determina que o
} 
Em sistemas jurídicos como o brasileiro, que adotam o critério difuso de controle de constitucionalidade, a inconstitucionalidade de uma norma jurídica pode ser declarada por qualquer órgão pertencente ao Poder Judiciário, respeitadas as normas processuais de distribuição de competência. ${ }^{198}$

Como visto acima (item 2.4.3), o sistema brasileiro, a partir da Emenda Constitucional n ${ }^{\circ}$ 16, de 26 de novembro de 1965, à Constituição de 1946, prevê, ao lado da via incidental de controle de constitucionalidade, a possibilidade de este ser exercido pela via principal, por meio de ação direta e da arguição de descumprimento de preceito fundamental.

Pela via principal, a competência para o processo e julgamento das ações de controle de constitucionalidade é instituída no próprio texto constitucional. Ao Supremo Tribunal Federal foi atribuída a competência originária para processar e julgar a ação direta de inconstitucionalidade e de constitucionalidade de atos normativos federais ou estaduais (art. 102, I, a, e art. 103), a ação direta de inconstitucionalidade por omissão (art. 103 , $\S 2^{\circ}$ ) e a arguição de descumprimento de preceito fundamental, acerca da qual o texto constitucional prevê seja criada por meio de lei (art. 102, parágrafo único da redação original, transformado em $\S 1^{\circ}$ pela EC $n^{\circ}$ 3/93). Aos tribunais dos Estados, por meio de seu plenário ou de seu respectivo órgão especial, compete o processo e julgamento da representação de inconstitucionalidade de leis ou atos normativos estaduais ou municipais em face das Constituições dos Estados-membros (cabendo aos próprios Estados instituírem-na, conforme previsto pelo art. 125, § 2 , combinado com art. 97, caput, da Carta Federal).

princípio do juiz natural seja aplicado tanto ao processo civil como ao processo penal, ou ainda em processos de natureza jurídico-política, e até mesmo nos procedimentos administrativos disciplinares”. In: CONEGLIAN, Olivar Augusto Roberti. Princípio do juiz natural, apud OLIVEIRA NETO, Olavo de; LOPES, Maria Elizabeth de Castro (orgs.). Princípios processuais civis na Constituição. Rio de Janeiro, Campus Jurídico, 2008, p. 158.

${ }^{198}$ Os órgãos do Poder Judiciário estão previstos no art. 92 da Constituição Federal, quais sejam: "I- o Supremo Tribunal Federal; I-A- o Conselho Nacional de Justiça; II- o Superior Tribunal de Justiça; III- os Tribunais Regionais e Juízes Federais; IV- os Tribunais e Juízes do Trabalho; V- os Tribunais e Juízes Eleitorais; VI- os Tribunais e Juízes Militares; VII- os Tribunais e Juízes dos Estados e do Distrito Federal e Territórios.” 
Pode-se dizer, assim, que estes órgãos, e somente eles, configuram o órgão competente, o juízo natural, para o conhecimento e julgamento dos processos de controle principal de constitucionalidade.

A par dessas previsões, a Constituição de 1988 estipula que somente pelo voto da maioria absoluta de seus membros ou de membros do respectivo órgão especial poderão os tribunais declarar a inconstitucionalidade de lei ou ato normativo do poder público (art. 97). Trata-se de regra que tem origem no Direito norte-americano, introduzida entre nós pela Constituição de 1934, voltada, inicialmente, apenas aos julgamentos proferidos no controle incidental de constitucionalidade. ${ }^{199}$

Conhecida pelas designações de full bench, full court, ou en banc, ou, ainda, como princípio da reserva de plenário, essa regra tem, atualmente, reconhecida aplicação tanto ao controle incidental de constitucionalidade, como no controle principal de constitucionalidade.

Determina o artigo 97 da Constituição Federal que a inconstitucionalidade só pode ser declarada pela maioria absoluta ${ }^{200}$ dos votos dos integrantes do tribunal ou órgão especial competente para o julgamento da matéria.

\footnotetext{
${ }^{199}$ Em monografia sobre o tema, elucida JOSÉ LEVY MELLO DO AMARAL NETO que: “A regra do full bench tem, por contexto originário, o controle difuso e em concreto de normas realizado no âmbito dos órgãos jurisdicionais colegiados”. In: AMARAL NETO, José Levy Mello do. Incidente de argüição de inconstitucionalidade: Comentários ao art. 97 da Constituição e aos arts. 480 e 482 do Código de Processo Civil. São Paulo, Revista dos Tribunais, 2002, p. 19.

Esclarece, ainda, que no "século XIX, por construção jurisprudencial, assentou-se, em algumas cortes dos Estados Unidos, orientação para 'não decidir se uma lei é inconstitucional apenas pela maioria do quorum mínimo de juízes - menos que a maioria de todos - ficando a discussão adiada até que o tribunal esteja completo', o que pareceu, para Thomas Cooley, 'uma muito prudente e apropriada precaução a ser observada antes de ingressar em questões tão delicadas e importantes'. A doutrina e a jurisprudência estadunidenses denominam a orientação em causa de full bench, full court ou, ainda, en banc”. In: Ibidem, p. 19-20.

${ }^{200}$ Maioria absoluta é critério obtido facilmente considerando-se o primeiro número inteiro após a metade dos membros do tribunal. No caso do Supremo Tribunal Federal, portanto, a maioria absoluta seria o equivalente a 6 (seis) Ministros. JOSÉ AFONSO DA SILVA, comentando o quórum para deliberações no processo legislativo, expõe a essência do conceito: "Maioria absoluta é mais da metade, constitui-se a partir do primeiro número inteiro acima da metade, sendo erro considerá-la como metade mais um, como não raro se ouve ou lê, visto que será impossível apurá-la quando a Câmara se compuser de número ímpar de membros”. In: SILVA, José Afonso da. Curso de direito constitucional positivo. 24a ed., São Paulo, Malheiros Editores, 2005, p. 519.
} 
Como lembra LÚCIO BITTENCOURT, a regra do full bench não se confunde com o quorum para a realização da sessão de julgamento:

“Ao contrário do que comumente se afirma, a Constituição não fixou o quorum dos tribunais para o julgamento da inconstitucionalidade. Desde o Estatuto de 1934 que apenas se condiciona a declaração deste ao pronunciamento, neste sentido, da maioria dos membros dos tribunais. Isto, porém, nada tem que ver com o quorum, porque este, segundo a definição vulgar, perfeitamente coincidente com o sentido técnico, significa o número de pessoas cujo concurso ativo ou passivo é indispensável ao funcionamento válido de alguma assembléia. A Constituição não determina o número de juízes que devem estar presentes, nem exige o comparecimento da totalidade destes, mas, apenas, condiciona a eficácia jurídica da declaração de inconstitucionalidade ao pronunciamento da maioria dos membros do tribunal." 201

Esse entendimento é referendado em sede de controle abstrato de constitucionalidade pelo fato de o quorum para funcionamento do tribunal vir expresso em lei ${ }^{202}$, bem como no regimento interno dos tribunais, a exigir que a sessão de julgamento só tenha início se presentes, no caso do Supremo Tribunal Federal, ao menos oito Ministros (ou dois terços dos Ministros, conforme previsto na lei que regula a arguição de descumprimento de preceito fundamental).

BITTENCOURT vai mais longe, afirmando que o full bench não só não consistiria uma regra de funcionamento (quorum para funcionamento do tribunal), como também não se configuraria como uma regra de competência, mas sim como uma condição de eficácia da decisão. ${ }^{203}$

${ }^{201}$ BITTENCOURT, Lúcio. O Controle de constitucionalidade das leis. Forense, Rio de Janeiro, $2^{\mathrm{a}}$ ed., 1968, p. 43.

${ }^{202}$ Lei federal n ${ }^{0}$ 9.868/99, art. 22: “A decisão sobre a constitucionalidade ou a inconstitucionalidade da lei ou do ato normativo somente será tomada se presentes na sessão pelo menos oito Ministros"; Lei federal n ${ }^{0}$ 9.882/99, art. 8': "A decisão sobre a arguição de descumprimento de preceito fundamental somente será tomada se presentes na sessão pelo menos 2/3 (dois terços) dos Ministros."

203 "O art. 200 da Constituição não tem outro efeito senão o de condicionar a eficácia jurídica da decisão declaratória da inconstitucionalidade ao voto - nem mesmo à presença, mas ao voto, pronunciado pela forma que a lei ordinária estabelecer - da maioria dos membros do tribunal. O referido preceito não é, em si mesmo, nem uma regra de funcionamento, nem uma norma de competência: estabelece apenas uma condição de eficácia". In: BITTENCOURT, Lúcio. O Controle de constitucionalidade das leis. Forense, Rio de Janeiro, $2^{\mathrm{a}}$ ed., 1968, p. 45-46. 
A competência para conhecimento e julgamento das ações de controle abstrato de constitucionalidade, como visto acima, é prevista na própria Constituição. Não obstante, a regra do artigo 97 da Carta de 1988 tem sido reconhecida como uma regra de competência para o julgamento que envolva inconstitucionalidade de lei ou ato normativo pela doutrina $^{204}$ e jurisprudência ${ }^{205}$ nacionais.

Entendo que do conteúdo do artigo 97 da Constituição de 1988 embora o artigo não estipule diretamente a competência para o julgamento, pois trata, efetivamente, de uma exigência específica para o julgamento em que se declara a inconstitucionalidade de ato normativo - infere-se, como dedução lógica, que o julgamento das ações de controle abstrato de constitucionalidade somente pode ser realizado pelo Plenário do Supremo Tribunal Federal ou pelo Plenário do Tribunal de Justiça estadual - ou, ainda, por seu Órgão Especial, onde houver - quando for processo de sua competência.

204 JOSÉ LEVI MELLO DO AMARAL JÚNIOR infirma o entendimento de LÚCIO BITTENCOURT, com fundamento em lição de PONTES DE MIRANDA, mediante a aplicação conjunta do artigo 97 com os dispositivos da lei ordinária que o regulamentaram: "conjugando-se o art. 97 da Constituição de 1988 com o art. 481 do CPC, revela-se tecnicamente mais preciso o entendimento de Pontes de Miranda, em especial considerando que a validade de qualquer ordem estatal - seja qual for a sua natureza (legislativa, administrativa ou jurisdicional) - guarda íntima relação com a competência, para o ato, do órgão do qual emana. Ora, a legislação pátria determina seja a declaração de inconstitucionalidade proferida pela maioria absoluta dos membros do tribunal, membros esses reunidos em plenário ou órgão especial.

Não se trata, aqui, de interpretar a Constituição a partir da lei (prática essa rejeitada pelo Supremo Tribunal Federal). Com efeito, o art. 97 nada tem a ver, de per si, com a competência de órgão jurisdicional para uma dada causa. Estão corretas a doutrina e jurisprudência prevalentes a esse respeito. No entanto, a lei ordinária processual, dentre diversas opções legislativas possíveis, regulamentou o art. 97 determinando fosse o incidente de argüição de inconstitucionalidade processado perante o tribunal pleno, ou perante o respectivo órgão especial, onde houver. O art 481 do CPC encerra, ele sim, típica regra de competência.” In: AMARAL JÚNIOR, José Levi Mello do. Incidente de argüição de inconstitucionalidade: Comentários ao art. 97 da Constituição e aos arts. 480 e 482 do Código de Processo Civil. São Paulo, Revista dos Tribunais, 2002, p. $42-43$.

205 "É inquestionável que assiste a Suprema Corte, em sua composição plenária, a competência exclusiva para julgar o processo de controle concentrado de constitucionalidade e, pelo voto da maioria absoluta dos seus membros, declarar a inconstitucionalidade de lei ou ato normativo do Poder Público (CF, art. 97; RISTF, art. 5, VII e art. 173). Essa regra de competência, no entanto, muito embora de observância indeclinável por qualquer órgão judiciário colegiado, não subtrai ao Relator da causa o poder de efetuar - enquanto responsável pela ordenação e direção do processo (RISTF, art. 21, I) - o controle 'prévio' dos requisitos formais da fiscalização normativa abstrata, o que inclui, dentre outras atribuições, o exame dos pressupostos processuais e das condições da própria ação direta. A possibilidade de controle recursal, 'a posteriori', dos atos decisórios que o Relator pratica, no desempenho de sua competência monocrática, dá concreção, no âmbito do Supremo Tribunal Federal, ao 'princípio da reserva de Plenário', inscrito no art. 97 da Lei Fundamental da Republica”. In: ADI-AgR 531/DF, Rel. Min. CELSO DE MELLO, Julgamento: 11/12/1991, Tribunal Pleno, Publicação DJ 0304-1992, pp. 04288, Ement. vol. 01656-01, p. 95, RTJ vol. 0139-01, p. 67, (grifos nossos). 


\subsubsection{Decisões monocráticas [Lei federal $\mathrm{n}^{\circ}$ 9.868/99, art. $4^{\circ}$ (ADI) e art. 15 (ADC); Lei federal $n^{\circ}$ 9.882/99, art. $4^{\circ}$ (ADPF)]}

Outra questão que merece atenção é a relativa às decisões monocráticas proferidas em processos de controle abstrato de constitucionalidade.

O exame dos requisitos de admissibilidade da ação é previsto nas leis que regulam o procedimento das ações de controle de constitucionalidade, cabendo ao relator indeferi-las liminarmente [Lei federal $\mathrm{n}^{\circ}$ 9.868/99, art. $4^{\circ}$ (ADI) e art. 15 (ADC); Lei federal $n^{\circ}$ 9.882/99, art. $4^{\circ}$ (ADPF)] caso não se encontrem presentes os requisitos necessários ao conhecimento e julgamento da ação. ${ }^{206}$

É preciso ter em vista que, quando o relator indefere a petição inicial por inépcia, não há exame acerca da constitucionalidade da norma, mas mera análise de requisitos de natureza processual, como a legitimidade de parte, interesse de agir, capacidade postulatória etc. Sendo a regra do artigo 97 voltada a impedir a declaração de inconstitucionalidade de lei ou ato normativo sem que haja apreciação do plenário, não resta ele vulnerado pela decisão monocrática que analisa aspectos meramente processuais.

Por outro lado, ambas as leis preveem que, da decisão de indeferimento, cabe agravo (inominado) ao Tribunal Pleno [Lei federal $\mathrm{n}^{\circ}$ 9.868/99, art. $4^{\circ}$, parágrafo único (ADI), e art. 15, parágrafo único (ADC); Lei federal nº 9.882/99, art. $4^{\circ}$, § $1^{\circ}$ (ADPF)], no prazo de cinco dias, a assegurar o direito da parte interessada em relação a eventuais equívocos da decisão e resguardar a efetividade dos princípios do juiz natural, da colegialidade e da reserva de plenário.

\footnotetext{
${ }^{206}$ Neste ponto, GILMAR FERREIRA MENDES, em obra conjunta com IVES GANDRA DA SILVA MARTINS, entende que, neste caso, aplica-se o conceito de inépcia positivado no Código de Processo Civil (art. 295), havendo de ser considerada inepta a petição que não atender aos requisitos do art. $3^{\circ}$ da Lei federal $n^{\circ}$ 9.868/99, aplicando-se subsidiariamente o diploma processual civil. A esse respeito, v. MENDES, Gilmar Ferreira; MARTINS, Ives Gandra da Silva. Controle concentrado de constitucionalidade: Comentários à Lei nº 9.868, de 10-11-1999. $3^{\text {a }}$ ed., São Paulo, Saraiva, p. 281-282.
} 
É essa a posição do Supremo Tribunal Federal, como se pode verificar pelo exame do acórdão relatado pelo Ministro CELSO DE MELLO, citado acima (vide nota 198, supra). ${ }^{207}$

Dessa forma, caso o requerente da ação declaratória não se conforme com a decisão monocrática, pode recorrer ao Plenário que, então, analisará a questão de forma definitiva. Preservados estão, assim, os princípios do juiz natural, da colegialidade e da reserva de plenário, prestigiando-se, por outro lado, o princípio da celeridade processual (CF, art. $5^{\circ}$, LXXVIII), na hipótese em que o requerente se satisfizer com o teor da decisão monocrática e dela não recorrer.

Já de duvidosa constitucionalidade a decisão monocrática que, com fundamento no artigo 543-B do C.P.C. e no $\S 1^{\circ}$ do artigo 21 do RISTF, nega seguimento ao agravo regimental interposto contra decisão também monocrática que inadmite a petição inicial de ação direta de inconstitucionalidade. ${ }^{208}$ Aqui, com a devida vênia, parece não ter havido acerto na decisão apontada, pois, neste caso, há uma indevida e incontornável

\footnotetext{
207 No mesmo sentido: “A Autora não tem legitimidade ativa ad causam para propor ação direta de inconstitucionalidade, para a qual somente são legitimadas autoridades e entidades relacionadas no art. 103 da Constituição da República. Em situações como a que aqui se apresenta, o Supremo Tribunal Federal tem admitido que o Relator, monocraticamente, negue seguimento aos pedidos de declaração de inconstitucionalidade por não estar contemplado o cidadão, como a Autora, no rol do art. 103 da Constituição da República.” In: ADI 4185/DF-DISTRITO FEDERAL. Rel. Min. CÁRMEN LÚCIA. Julgamento: 05/02/2009. Publicação: DJe-030. Divulg.: 12/02/2009. Public.: 13/02/2009.

208 "Ressalte-se, ainda, que o Plenário deste Tribunal reconheceu a validade constitucional da norma legal que inclui, na esfera de atribuições do Relator, a competência para negar seguimento, por meio de decisão monocrática, a recursos, a pedidos ou a ações, quando inadmissíveis, intempestivos, sem objeto ou que veiculem pretensão incompatível com a jurisprudência predominante deste Supremo Tribunal: 'A tese dos impetrantes, da suposta incompetência do relator para denegar seguimento a mandado de segurança, encontra firme repúdio neste Tribunal. A Lei 8.038/90, art. 38, confere-lhe poderes processuais, para, na direção e condução do processo, assim agir. Agravo regimental improvido’ (MS 21.734-AgR/MS, Rel. Min. Ilmar Galvão). Nesse sentido, nos termos do art. $21, \S 1^{\circ}$, do RISTF, poderá o Relator: 'negar seguimento a pedido ou recurso manifestamente inadmissível, improcedente ou contrário à jurisprudência dominante ou a Súmula do Tribunal, deles não conhecer em caso de incompetência manifesta, encaminhando os autos ao órgão que repute competente, bem como cassar ou reformar, liminarmente, acórdão contrário à orientação firmada nos termos do art. 543-B do Código de Processo Civil' (grifei). Isso posto, nego seguimento ao agravo regimental. Mantida, em consequência, por seus próprios fundamentos, a decisão de fls. 25-26. Arquivem-se os autos. Publique-se. Brasília, 6 de maio de 2009.” Decisão monocrática proferida pelo Ministro RICARDO LEWANDOWSKI na ADI no 4231 AgR/RJ-RIO DE JANEIRO. Julgamento: 06/05/2009. Publicação DJe-087 Divulg. 12/05/2009 Public. 13/05/2009.
} 
subtração ao Plenário do Supremo Tribunal Federal do pedido de declaração de inconstitucionalidade, que se revela inconciliável com o princípio da reserva de plenário.

É inegável que o relator tenha amplos poderes para negar trânsito, em decisão monocrática, a recursos, pedidos ou ações, quando incabíveis, estranhos à competência do STF, intempestivos, sem objeto ou que veiculem pretensão incompatível com a jurisprudência predominante daquele tribunal, como bem tem sido reconhecido pela jurisprudência daquela Corte (RTJ 139/53 e RTJ 168/174-175). Todavia, o cerceamento absoluto ao acesso ao Plenário, por decisão monocrática que indefere seguimento a agravo regimental interposto em processo de controle abstrato de constitucionalidade, enseja mácula indelével ao princípio da colegialidade e ao princípio da reserva de plenário. ${ }^{209}$

O agravo contra a decisão do relator que indefere a petição inicial é previsto nas leis específicas (Lei federal nº 9.868/99, art. 4º parágrafo único, e art. 15, parágrafo único; Lei federal $n^{\circ} 9.882 / 99$, art. $4^{\circ}, \S 1^{\circ}$ ), que não contêm disposição análoga àquela prevista no artigo 543-B do CPC e no $\S 1^{\circ}$ do artigo 21 do RISTF, motivo pelo qual me parece inadequada a aplicação subsidiária desses dispositivos no procedimento de jurisdição constitucional em sentido estrito.

Ressalte-se que a aplicação subsidiária do CPC e do Regimento Interno do Supremo Tribunal Federal neste caso poderia inviabilizar o controle da norma arguida de inconstitucional. Vislumbra-se que o controle quanto ao procedimento está intimamente ligado ao próprio exercício do controle de constitucionalidade, a ponto de inviabilizá-lo. Dessa forma, não se pode aceitar, com a devida vênia, que a decisão final acerca do cabimento da ação de inconstitucionalidade fique a cargo do relator do feito, quando a norma constitucional confere competência ao plenário do tribunal para essa análise.

\footnotetext{
${ }^{209}$ Em decisão monocrática, o Min. CELSO DE MELLO enfatiza a possibilidade de o Relator exercer amplos poderes quanto à admissibilidade da ação ou recurso, inclusive em sede de poder normativo. Todavia, esclarece que o princípio da colegialidade resta preservado desde que se assegure a possibilidade de recurso ao órgão colegiado: v. ADPF 45/DF - Distrito Federal, CELSO DE MELLO, decisão publicada no D. J. $n^{\circ}$ 84, do dia 04/05/2004.
} 
Essa hipótese revela-se como um típico caso em que deve se invocar o princípio da especialidade do processo de controle abstrato para impedir a aplicação subsidiária das normas do Código de Processo Civil, voltadas a regular o processo comum.

\subsubsection{Decisões cautelares [Lei federal $\mathrm{n}^{\circ}$ 9.868/99, art. 10 (ADI), art. 21 (ADC); e Lei federal $n^{\circ}$ 9.882/99, art. $5^{\circ}$ (ADPF)]}

A decisão cautelar em sede de controle abstrato de constitucionalidade tem o efeito de suspender a eficácia da lei arguida de inconstitucional, com eficácia erga omnes e efeitos, em regra, não retroativos (ex nunc), conforme prevê o § $1^{\circ}$ do artigo 11 da Lei federal $n^{\circ} 9.868 / 99^{210}$, motivo pelo qual há de ser, igualmente, proferida mediante o quorum de maioria absoluta [Lei federal $n^{\circ}$ 9.868/99, art. 10 (ADI) ${ }^{211}$ e art. 21 $(A D C)^{212}$; e Lei federal $n^{\circ} 9.882 / 99$, art. $5^{\circ}(A D P F)^{213}$ ], pelo tribunal pleno.

Excepcionalmente, todavia, em casos de extrema urgência ou de perigo de lesão grave, ou, ainda, em período de recesso, as próprias leis específicas da ação direta de inconstitucionalidade e da arguição de descumprimento de preceito fundamental preveem a possibilidade de o relator conceder a medida cautelar, que deverá, posteriormente, ser submetida ao referendo do Tribunal Pleno (Lei federal $n^{0}$ 9.868/99, art. 10; Lei federal $n^{\circ}$ 9.882/99, art. $5^{\circ}, \S 1^{\circ}$ ). A concessão monocrática da medida cautelar justifica-se, portanto, em

\footnotetext{
210 “Art. 11. Omissis.

$\S 1^{\circ}$ - A medida cautelar, dotada de eficácia contra todos, será concedida com efeito ex nunc, salvo se o Tribunal entender que deva conceder-lhe eficácia retroativa.”

211 “Art. 10. Salvo no período de recesso, a medida cautelar na ação direta será concedida por decisão da maioria absoluta dos membros do Tribunal, observado o disposto no art. 22, após a audiência dos órgãos ou autoridades dos quais emanou a lei ou ato normativo impugnado, que deverão pronunciar-se no prazo de 5 (cinco) dias.”

212 “Art. 21. O Supremo Tribunal Federal, por decisão da maioria absoluta de seus membros, poderá deferir pedido de medida cautelar na ação declaratória de constitucionalidade, consistente na determinação de que os juízes e os Tribunais suspendam o julgamento dos processos que envolvam a aplicação da lei ou do ato normativo objeto da ação até seu julgamento definitivo.”

213 “Art. 5. O Supremo Tribunal Federal, por decisão da maioria absoluta de seus membros, poderá deferir pedido de medida liminar na argüição de descumprimento de preceito fundamental.”
} 
decorrência de sua urgência, de modo a evitar o perecimento do direito, devendo ser posteriormente referendada pelo plenário.

Frise-se que inexiste previsão análoga para a ação declaratória de constitucionalidade, cuja cautelar deve obedecer, assim, a reserva de plenário, em decorrência das peculiaridades do procedimento desta ação, que impedem a análise da medida cautelar pelo juízo monocrático.

Por fim, ressalte-se que não se coadunam com o princípio da reserva de plenário as disposições de regimentos internos de Tribunais de Justiça estaduais que conferem ao presidente do tribunal, ou ao relator do feito, a competência para a análise e concessão da medida cautelar monocraticamente. ${ }^{214}$ Aí me parece evidente o não atendimento ao princípio da reserva de plenário, pois, ressalvadas as situações de emergência, só o Plenário do Tribunal tem a competência para suspender a eficácia da lei e não um de seus membros isoladamente. ${ }^{215}$ Em paralelo com a aprovação da lei, que só ocorre pela manifestação coletiva no seio do Parlamento, a suspensão posterior de sua eficácia, por ato do Poder Judiciário, só pode ocorrer pela manifestação do colegiado e não de um de seus membros.

\footnotetext{
${ }^{214} \mathrm{O}$ antigo Regimento Interno do Tribunal de Justiça do Estado de São Paulo, por exemplo, em seu art. 668 dispunha que: "Compete ao Presidente do Tribunal a apreciação de pedido de medida cautelar, cabendo agravo para o Órgão Especial.” Já o novo Regimento Interno do Tribunal (publicado no Diário da Justiça do Estado de São Paulo de 2 de outubro de 2009), apesar de prescrever que a ação direta de inconstitucionalidade será processada conforme a Constituição do Estado e a legislação (RITJ, art. 26, citando aqui expressamente a Lei federal n ${ }^{\circ}$ 9.868/99), dispõe que "caberá ao relator a apreciação da medida cautelar, ressalvada a hipótese do art. 165 , § $2^{\circ}$, deste Regimento” (art. 227).

${ }^{215}$ Nesse sentido, veja-se o entendimento de CLÉMERSON MERLIN CLÈVE: “Não parecer ser compatível com o disposto no art. 97 da Constituição Federal a concessão de medida liminar em ação direta de inconstitucionalidade por decisão monocrática. Assim como o ato normativo do Poder Público somente pode ser declarado inconstitucional com a manifestação, nesse sentido, da maioria absoluta dos membros do STF, sustando os efeitos de lei aprovada por mais de quinhentos deputados, mais de oitenta senadores e sancionada pelo Presidente da República. É evidente que a possibilidade de concessão de liminares por um único Ministro pode dar lugar a abusos, bem como a atritos desnecessários entre os Poderes da República, quando não a crises de natureza política.” In: CLÈVE, Clémerson Merlin. A fiscalização abstrata de constitucionalidade. $2^{\mathrm{a}}$ ed., São Paulo, Revista dos Tribunais, 2000, p. 237.
} 


\subsubsection{O princípio da ação ou da demanda. A inércia da jurisdição constitucional [Lei federal $n^{\circ} 9.868 / 99$, art. $2^{\circ}$ (ADI) e art. 13 (ADC); Lei federal ${ }^{\circ} 9.882 / 99$, art. $2^{\circ}$ (ADPF)]}

O princípio da ação ou da demanda veda ao juiz ou órgão jurisdicional a instauração do processo de ofício (ne procedat ex officio) e, via de consequência, impede, igualmente, a tomada de providências que superem os limites do pedido: ne eat iudex ultra petita partium (cf. CPC, arts. 459 e 460). ${ }^{216}$ Portanto, esse princípio está intimamente ligado ao princípio da congruência, a coibir o órgão jurisdicional de conceder medida distinta daquela veiculada no pedido. ${ }^{217}$

No Código de Processo Civil, o princípio da ação ou demanda é previsto nos artigos $2^{\circ}$ e 262. Já nas ações de controle abstrato, a necessidade de iniciativa dos legitimados ativos para dar início à jurisdição constitucional decorre das normas insertas nos artigos $2^{0218}$ e $13^{219}$ da Lei federal $n^{\circ} 9.868 / 99$ e no artigo $2^{\circ}$ da Lei federal $n^{\circ} 9.882 / 99^{220}$, a exigir, necessariamente, a provocação dos legitimados, a demanda, para dar início ao processo.

A sua aplicação no processo comum é justificada diante da inconveniência social de se realizar processos para alguém que não se animou a pedir a tutela e com vistas à preservação da imparcialidade do juiz. ${ }^{221}$

\footnotetext{
${ }^{216}$ ARAÚJO CINTRA, Antonio Carlos de; GRINOVER, Ada Pellegrini; DINAMARCO, Cândido Rangel. Teoria geral do processo. $25^{\mathrm{a}}$ ed., São Paulo, Malheiros, 2009, p. 63-66.

${ }^{217}$ Neste sentido, CELSO AGRÍCOLA BARBI: "Do princípio da demanda decorrem outras conseqüências, com a de que o juiz não pode decidir além do que foi pedido pelo autor, nem considerar questões não apresentadas pelas partes, para as quais a lei exige iniciativa dos litigantes - ne eat judex ultra petita partium.” In: BARBI Celso Agrícola. Comentários ao Código de Processo Civil, v. I. 10ª ed., Rio de Janeiro, Editora Forense, 1988, p. 15.

218 "Art. $2^{\circ}$ Podem propor a ação direta de inconstitucionalidade: [...]”

219 "Art. 13. Podem propor a ação declaratória de constitucionalidade de lei ou ato normativo federal: [...]"

220 "Art. $2^{\circ}$ Podem propor a arguição de descumprimento de preceito fundamental: [...]"

${ }^{221}$ DINAMARCO, Cândido Rangel. Instituições de direito processual civil, v. II. 6 a ed., São Paulo, Malheiros, 2009, p. $42-43$.
} 
Segundo a concepção clássica, por tratar o processo civil de interesses predominantemente particulares, seria razoável atribuir às partes a escolha acerca do momento em que se pretende propor a ação e a determinação do objeto do litígio. ${ }^{222}$

Por outro lado, tem o princípio em questão a função de resguardar a imparcialidade do magistrado, na medida em que se volta a separar as funções de pedir e de julgar, pois se ao juiz fosse atribuída a prerrogativa de iniciar o processo e delimitar a sua extensão, “abrir-se-ia grande flanco para que o juiz se apresentasse na causa como partidário de uma tese, esposando, já no início do processo um objetivo quanto ao litígio e uma opinião formada a seu respeito". 223

O princípio da demanda não se confunde com o princípio dispositivo. De fato, o princípio da demanda impõe que a parte dê início ao processo e fixe a sua amplitude, impedindo o magistrado de praticar estes atos; diz, assim, respeito ao direito material do requerente. O princípio dispositivo, por sua vez, tem maior ligação com aspectos processuais, relativos à condução do processo. Dessa forma, se o processo move-se predominantemente por impulso oficial, revela-se como processo de natureza inquisitória, enquanto que se o seu desenvolvimento decorre da atividade das partes, mostra-se como processo de cunho dispositivo ou acusatório. ${ }^{224}$

A provocação da parte é elemento característico do próprio exercício da função jurisdicional. CAPPELLETTI, ao comentar o modelo francês de controle de constitucionalidade, acentuando a função não propriamente jurisdicional exercida pelo Conseil Constitutionnel, esclarece que tal ocorre não apenas pela natureza antes política que judiciária do órgão, “mas também e especialmente pelo caráter necessário, pelo menos no que diz respeito às leis orgânicas, do controle que se desenvolve, portanto, sem um verdadeiro

\footnotetext{
${ }^{222}$ ARENHART, Sérgio Cruz. Reflexões sobre o princípio da demanda, In: FUX, Luiz; NERY JÚNIOR, Nelson; WAMBIER, Teresa Arruda Alvim (coord.). Processo e Constituição. Estudos em homenagem ao Professor José Carlos Barbosa Moreira. São Paulo, Revista dos Tribunais, 2006, p. 587.

${ }^{223}$ ARENHART, Sérgio Cruz. Reflexões sobre o princípio da demanda, In: FUX, Luiz; NERY JÚNIOR, Nelson; WAMBIER, Teresa Arruda Alvim (coord.). Processo e Constituição. Estudos em homenagem ao Professor José Carlos Barbosa Moreira. São Paulo, Revista dos Tribunais, 2006, p. 588.

${ }^{224}$ Ibidem, p. 590.
} 
recurso ou impugnação da parte (ubi non est actio, ibi non est jurisdictio!), bem como pelo caráter preventivo da função de ‘controle’ por aquele órgão exercida”. 225

Analisando a jurisdição constitucional alemã, cujo exercício condiciona-se, igualmente, ao princípio do pedido, GILMAR FERREIRA MENDES elucida que o Bundesverfassungsgericht somente atua mediante provocação. ${ }^{226}$ Afirma, igualmente, que o princípio do pedido é essencial para a qualificação de órgão decisório como um Tribunal, a delinear a conformação do exercício da jurisdição constitucional:

"A forma judicial constitui característica peculiar que permite distinguir a atuação da jurisdição constitucional de outras atividades, de cunho meramente político. Enquanto o Parlamento pode decidir livremente quando determinada matéria será disciplinada por lei, ao Bundesverfassungsgericht é vedado tomar iniciativas próprias."227

O controle de constitucionalidade em via principal configura meio de exercício, ainda que especialíssimo, da função jurisdicional, como pude explicar no item 2.1.2 da presente dissertação. Tratando-se de exercício de função jurisdicional, não se pode prescindir da provocação do interessado para que tenha início o processo de verificação abstrata.

A inércia da jurisdição constitucional é um elemento fundamental ao equilíbrio e harmonia entre os Poderes, pois, pudesse o tribunal sponte sua dar início ao processo de controle de constitucionalidade, a sua função tornar-se-ia demasiadamente proeminente nas relações institucionais, tornando-o uma espécie de superpoder, acima dos demais, a exercer sobre eles permanente controle. Assim, no controle principal de constitucionalidade, o princípio da ação, ou da demanda, assume um importante aspecto político, na conformação do equilíbrio entre os Poderes constituídos. ${ }^{228}$

\footnotetext{
${ }^{225}$ CAPPELLETTI, Mauro. O controle judicial de constitucionalidade das leis no direito comparado. $2^{\mathrm{a}}$ ed. Porto Alegre, Sérgio A. Fabris, Editor, 1999, p. 29.

${ }^{226}$ MENDES, Gilmar Ferreira. Jurisdição Constitucional. 5a ed., São Paulo, Saraiva, 2005, p. 106.

227 Ibidem, p. 106-107.

${ }^{228}$ Fazendo um contraponto com a natureza objetiva do processo de controle abstrato de normas, pondera JULIANO TAVEIRA BERNARDES: “considerando tratar-se de processo objetivo, que não possui partes no sentido substancial e cujo interesse tutelado compreende a própria higidez constitucional da ordem jurídica, cabe
} 
VITALINO CANAS, analisando a conveniência ou não de o Tribunal Constitucional ter a sua atuação condicionada à provocação dos interessados, pondera que:

\begin{abstract}
“A razão da consagração do subprincípio do pedido nesta sua primeira vertente da iniciativa exterior reside na necessidade de impedir que o Tribunal Constitucional obtenha um ascendente asfixiante sobre os demais órgãos constitucionais. Se se permitisse ao órgão de fiscalização o exercício ex officio dos seus poderes, o perigo de transformação desse órgão numa 'superpotência constitucional' agravar-se-ia incomportavelmente. Se o Tribunal agisse independentemente de qualquer acto de iniciativa resultante de uma manifestação da vontade de outra entidade, disporia de mais um importante poder de intervenção no viver social, podendo escolher, quiçá com recursos a critérios eminentemente políticos, o momento de intervir, as normas e matérias a apreciar, etc."229
\end{abstract}

Deve-se ter em vista, ainda, que o princípio da demanda vem sofrendo um abrandamento pela moderna doutrina processual, mesmo nos processos de índole subjetiva. Um exemplo claro de tal fato é a disciplina das sentenças que tratam de obrigação de fazer (CPC, arts. 461 e 461-A e CDC, art. 84), nas quais a tutela a ser prestada pode ser adaptada às peculiaridades do caso concreto, segundo o critério do magistrado.

Também no controle abstrato de constitucionalidade, o princípio da demanda sofre condicionamentos, em face do reconhecimento da inconstitucionalidade consequencial ou por arrastamento, como ficará demonstrado a seguir (item 3.2.4 infra).

Por outro lado, estando o Tribunal adstrito ao princípio da demanda e ao princípio da congruência (que prevê a correspondência entre pedido e decisão judicial, como será analisado adiante), torna-se o pedido inicialmente formulado um

perguntar qual teria sido o motivo da consagração de princípio ligado aos processos dispositivos no controle abstrato de constitucionalidade. A razão parece ser esta: busca-se impedir assuma o órgão controlador posição ascendente no quadro institucional, o que poderia trazer risco de asfixia às demais funções estatais. Cuida-se de fórmula para evitar eventual supremacia do órgão fiscalizador. Por meio dela, consagra-se equilibrada equação entre os que têm a faculdade de iniciativa e aquele que detém o poder de decidir a questão constitucional.” In: BERNARDES, Juliano Taveira. Controle Abstrato de Constitucionalidade. Elementos materiais e princípios processuais. São Paulo, Saraiva, 2004, p. 402.

${ }^{229}$ CANAS, Vitalino. Os processos de fiscalização da constitucionalidade e da legalidade pelo Tribunal Constitucional: Natureza e princípios estruturantes. Coimbra, Coimbra Editora, 1986, p. 105. 
importante instrumento para a compreensão do alcance da decisão final. De fato, como bem esclarece HUMBERTO THEODORO JÚNIOR:

\begin{abstract}
“Assim, as palavras com que o juiz acolheu ou rejeitou o pedido terão seu sentido e alcance clareados pelo que na inicial o autor demandou. Se houver alguma imprecisão ou alguma dubiedade na linguagem do sentenciante, a fixação do real sentido do comando jurisdicional será encontrada por meio de sua sistematização com o pedido.

Não se pode, como é óbvio, resolver a dúvida pela inteligência da sentença que a faça abranger o que não era objeto do processo. Com esse critério adota-se a interpretação conducente a mantê-la dentro da congruência obrigatória entre pedido e a prestação jurisdicional, e evita-se dar-lhe o impróprio sentido de ter decidido o que não era objeto do processo."230
\end{abstract}

Demanda, pedido e petição inicial são institutos de natureza diversa. Informa HUMBERTO THEODORO JÚNIOR que a demanda vem a ser, tecnicamente, o ato pelo qual alguém pede ao Estado a prestação jurisdicional. Já a petição inicial seria o veículo de manifestação formal da demanda, na qual o autor pode fazer duas manifestações: “a) a demanda da tutela jurisdicional do Estado, que causará a instauração do processo, com a convocação do réu; b) o pedido de uma providência contra o réu, que será objeto do julgamento final da sentença de mérito”. ${ }^{231}$

Nas ações diretas de inconstitucionalidade, por ação e omissão, e declaratórias de constitucionalidade, deve-se ter em vista que não há convocação do réu, nem tampouco pedido contra este. O processo é objetivo e o pedido volta-se à declaração de inconstitucionalidade ou constitucionalidade de determinada norma.

O processo, por sua vez, tem início com o ajuizamento da petição inicial, cujos requisitos estão previstos no art. $3^{\circ}$ (ADI) e no art. 14 (ADC) da Lei federal $n^{\circ} 9.868 / 99$, bem como no art. $3^{\circ}$ da Lei federal $n^{\circ}$ 9.882/99 (ADPF).

${ }^{230}$ THEODORO JÚNIOR, Humberto. Curso de Direito Processual Civil, v. I. $45^{\mathrm{a}}$ ed., Rio de Janeiro, Forense, 2006, p. 571.

${ }^{231}$ Ibidem, p. 392. 
Ressalte-se que não há prazo para o ajuizamento da ação (que, portanto, não prescreve), inexistindo igualmente decadência do direito à sua propositura. ${ }^{232}$

A petição inicial, acompanhada do instrumento de mandato (parágrafo único do art. $3^{\circ}$ e parágrafo único do art. 14 da Lei federal no 9.868/99 e parágrafo único do art. $3^{\circ}$ da Lei federal $\left.n^{\circ} 9.882 / 99\right)^{233}$, com poderes específicos para a impugnação do ato normativo inquinado de inconstitucional ${ }^{234}$, ressalvada a hipótese de ser subscrita por advogado público ${ }^{235}$, deve ser necessariamente formulada por escrito ${ }^{236}$ e apresentada em duas vias, acompanhada de cópias do ato questionado e dos documentos necessários à comprovação da impugnação [Lei federal nº 9.868/99, art. 3º parágrafo único (ADI); art. 14, parágrafo único (ADC) e Lei federal nº 9.882/99, art. 3º parágrafo único (ADPF)] e deverá indicar:

1. O preceito fundamental que se considera violado;

2. O dispositivo da lei ou do ato normativo impugnado;

3. Os fundamentos jurídicos do pedido em relação a cada uma das especificações;

4. A prova da violação do preceito fundamental;

232 “Ação direta de inconstitucionalidade e prazo decadencial. O ajuizamento da ação direta de inconstitucionalidade não está sujeito a observância de qualquer prazo de natureza prescricional ou de caráter decadencial, eis que atos inconstitucionais jamais se convalidam pelo mero decurso do tempo. Súmula 360". In: ADI 1.247-MC, Relator: Ministro CELSO DE MELLO. Julgamento em 17-8-95, DJ de 8-9-95.

${ }^{233}$ ADI 127 MC-QO/AL. Relator: Ministro CELSO DE MELLO. Julgamento: 20/11/1989. Órgão Julgador: Tribunal Pleno. Publicação: DJ 04-12-1992, p. 23057. Emet. Vol. 01687-01, p. 01. RTJ Vol. 144-01, p. 04; ADPF 33/PA. Relator: Ministro GILMAR MENDES. Julgamento: 07/12/2005. Órgão Julgador: Tribunal Pleno. Publicação: DJ 27-10-2006, p. 031. Ement. Vol. 02253-01, p. 01. RTJ Vol. 0199-03, p. 0873.

${ }^{234}$ ADI 2187/BA. Relator: Ministro OCTAVIO GALLOTTI. Julgamento: 15/06/2000. Órgão Julgador: Tribunal Pleno. Publicação: DJ 12-12-2003, p. 062. Emet. Vol. 02136-01, p. 095.

235 “REPRESENTAÇÃO PROCESSUAL - PROCESSO OBJETIVO - GOVERNADOR DO ESTADO. A representação processual do governador do estado no processo objetivo se faz por meio de credenciamento de advogado, descabendo colar a pessoalidade considerado aquele que, à época, era o chefe do Poder Executivo. REPRESENTAÇÃO PROCESSUAL - PROCESSO OBJETIVO - GOVERNADOR DO ESTADO. Atua o legitimado para ação direta de inconstitucionalidade quer mediante advogado especialmente credenciado, quer via procurador do Estado, sendo dispensável, neste último caso, a juntada de instrumento de mandato.” In: ADI 2728 ED/AM. Relator Ministro MARCO AURÉLIO. Julgamento: 19/10/2006. Órgão julgador: Tribunal Pleno. Publicação: DJe-117, divulg. 04-10-2007, public. 05-10-2007, p. 021. Ement. vol. 02292-01, p. 074. RTJ vol. 0202, p. 516.

${ }^{236}$ TAVEIRA BERNARDES afirma que a práxis judicial consagrou a modalidade escrita para a petição inicial. 2004, p. 404, nada impedindo que seja veiculada por meio de arquivo eletrônico, se disponível este sistema. Há também precedente impedindo o aditamento oral do pedido: Ação direta. Aditamento oral formulado pelo autor da ação por ocasião da apreciação do pedido de liminar. Impossibilidade.” ADI 654-MC, Relator: Ministro CARLOS VELLOSO. Julgamento em 11-12-91, DJ de 6-8-93. 
5. O pedido, com suas especificações;

5.1. Necessidade de impugnação de todo o complexo normativo referente à norma que se pretende declarar inconstitucional;

5.2. Impugnação de todo o complexo normativo e o direito revogado;

5.3. Modulação de efeitos;

5.4. Aditamento do pedido;

6. A existência de controvérsia judicial relevante sobre a aplicação da disposição objeto da ação declaratória de constitucionalidade;

7. A comprovação da existência de controvérsia judicial relevante sobre a aplicação do preceito fundamental que se considera violado.

\subsubsection{O preceito fundamental que se considera violado (Lei federal $\mathbf{n}^{\circ} 9.882 / 99$, art. $3^{\circ}$, I)}

Trata-se de requisito específico da arguição de descumprimento de preceito fundamental, cabendo ao requerente a indicação do preceito fundamental que entende violado.

Não há um consenso doutrinário acerca da extensão do conceito referente aos preceitos fundamentais. Em linhas gerais, segundo ALEXANDRE DE MORAES, pode-se dizer que consubstanciariam "os direitos e garantias fundamentais da Constituição, bem como os fundamentos e objetos fundamentais da República, de forma a consagrar maior efetividade às previsões constitucionais”. ${ }^{237}$

${ }^{237}$ MORAES, Alexandre de. Comentários à Lei ${ }^{0}$ 9.882/99: Arguição de Descumprimento de Preceito Fundamental. In: TAVARES, André Ramos; ROTHENBURG, Walter Claudius (orgs.), Arguição de descumprimento de preceito fundamental: análises à luz da Lei no 9.882/99. São Paulo, Atlas, 2001, p. 17. 
Na tentativa de fornecer elementos para a identificação do preceito fundamental, decidiu o Supremo Tribunal Federal:

"Parâmetro de controle - É muito difícil indicar, a priori, os preceitos fundamentais da Constituição passíveis de lesão tão grave que justifique o processo e julgamento da argüição de descumprimento. Não há dúvida de que alguns desses preceitos estão enunciados, de forma explícita, no texto constitucional. Assim, ninguém poderá negar a qualidade de preceitos fundamentais da ordem constitucional aos direitos e garantias individuais (art. $5^{\circ}$, dentre outros). Da mesma forma, não se poderá deixar de atribuir essa qualificação aos demais princípios protegidos pela cláusula pétrea do art. 60, $\S 4^{\circ}$, da Constituição, quais sejam, a forma federativa de Estado, a separação dos Poderes e o voto direto, secreto, universal e periódico. Por outro lado, a própria Constituição explicita os chamados 'princípios sensíveis', cuja violação pode dar ensejo à decretação de intervenção federal nos Estados-membros (art. 34, VII). É fácil ver que a amplitude conferida às cláusulas pétreas e a idéia de unidade da Constituição (Einheit der Verfassung) acabam por colocar parte significativa da Constituição sob a proteção dessas garantias. [...] Destarte, um juízo mais ou menos seguro sobre a lesão de preceito fundamental consiste nos princípios da divisão de Poderes, da forma federativa do Estado ou dos direitos e garantias individuais exige, preliminarmente, a identificação do conteúdo dessas categorias na ordem constitucional e, especialmente, das suas relações de interdependência. Nessa linha de entendimento, a lesão a preceito fundamental não se configurará apenas quando se verificar possível afronta a um princípio fundamental, tal como assente na ordem constitucional, mas também a disposições que confiram densidade normativa ou significado específico a esse princípio. Tendo em vista as interconexões e interdependências dos princípios e regras, talvez não seja recomendável proceder-se a uma distinção entre essas duas categorias, fixando-se um conceito extensivo de preceito fundamental, abrangente das normas básicas contidas no texto constitucional."238

Para efeito de identificação do pedido, a doutrina brasileira costuma denominar de causa de pedir remota os fatos constitutivos do pedido e de causa de pedir próxima os fundamentos jurídicos do pedido. Como bem elucida MOACYR DO AMARAL SANTOS, ao comentar o Código de Processo Civil:

"Chama-se a atenção para o texto da lei. O Código exige que o autor exponha na inicial o fato e os fundamentos jurídicos do pedido. Por esse modo faz ver que na inicial se exponha não só a causa de pedir próxima - os fundamentos jurídicos, a natureza do direito controvertido -, como também a causa remota - o fato gerador do direito. Quer dizer que o Código adotou a

${ }^{238}$ ADPF 33-MC, voto do Ministro GILMAR MENDES, julgamento em 29-10-03, D.J. de 6-8-2004. 
teoria da substanciação, como os códigos alemão e austríaco. Por esta teoria não basta a exposição da causa próxima, mas também se exige a da causa remota." 239

\begin{abstract}
ANDRÉ RAMOS TAVARES identifica na indicação do preceito fundamental que se considera violado a causa de pedir próxima do pedido na arguição de descumprimento de preceito fundamental, isto é, o fundamento jurídico que leva à configuração da lesão:
\end{abstract}

“O art. $3^{\circ}$ da Lei de Arguição determina que a petição inicial contenha: 'I - a indicação do preceito fundamental que se considera violado; II - a indicação do ato questionado ...'. Nesses dois incisos é possível vislumbrar a presença do que a doutrina denomina causa petendi, em seu dúplice desdobramento, a causa de pedir próxima e a remota.

Teoricamente, a causa de pedir próxima encontra-se nos fundamentos jurídicos do pedido (inc. I). A causa de pedir remota está no fato gerador ou desencadeador do direito (inc. II). Trata-se, em síntese, de um binômio: fundamento jurídico do pedido e fatos." 240

Acrescenta TAVARES, invocando entendimento de JOSÉ ROGÉRIO CRUZ E TUCCI, que a causa de pedir próxima seria a fundamentação jurídica da qual decorre o pedido:

“É o 'enquadramento da situação concreta, narrada in status assercionis, à previsão abstrata, contida no ordenamento de direito positivo, e do qual decorre a juridicidade daquela, e, em imediata seqüência, a materialização, no pedido, da conseqüência jurídica alvitrada pelo autor"."241

E conclui, afirmando que, no caso da ADPF, a causa de pedir próxima seria configurada pelo "direito de todos à ordem constitucional, vale dizer, a causa de pedir próxima é a primazia do princípio da supremacia da Constituição na resolução de todas as situações da vida”. 242

\footnotetext{
${ }^{239}$ SANTOS, Moacyr Amaral. Primeiras linhas de direito processual civil, v. 1. 26 $6^{\mathrm{a}}$ ed., São Paulo, Saraiva, 2009, p. 172.

${ }^{240}$ TAVARES, André Ramos. Tratado da argüição de descumprimento de preceito fundamental. São Paulo, Saraiva, 2001, p. 307-308.

${ }^{241}$ Ibidem, p. 314.

${ }^{242}$ Ibidem, p. 314.
} 
A causa de pedir próxima, isto é, a indicação dos fundamentos jurídicos do pedido, em meu sentir, não se restringe à simples indicação do preceito fundamental supostamente violado. Essa indicação é inegavelmente indispensável, mas me parece revelar-se mais como um requisito específico da ADPF que com a indicação geral dos fundamentos jurídicos que compõem a causa de pedir próxima.

Dessa forma, tratarei da matéria em item próprio, reservado ao princípio da especificação das normas (item 3.2.4, infra) e da congruência (item 3.2.5, infra).

\subsubsection{2 $\mathrm{O}$ dispositivo da lei ou do ato normativo impugnado [Lei federal $\mathrm{n}^{\circ} \mathbf{9 . 8 6 8} / \mathbf{9 9}$, art. $3^{\circ}$, inc. I, primeira parte (ADI); e art. 14, inc. I, primeira parte (ADC)], ou, para o caso de ADPF, a indicação do ato questionado (Lei federal $n^{\circ} 9.882 / 99$, art. $3^{\circ}$, II)}

Deve constar da petição inicial, expressamente, a transcrição da lei ou dos dispositivos de lei ou de ato normativo impugnados (deve igualmente constar a cópia destes, conforme determina o parágrafo único do art. $3^{\circ}$ e parágrafo único do art. 14 da Lei federal nº 9.868/99 e, ainda, o parágrafo único do art. $3^{\circ}$ da Lei federal nº 9.882/99).

No caso da arguição de descumprimento de preceito fundamental, o objeto da ação, como lembram NELSON NERY JUNIOR e ROSA MARIA DE ANDRADE NERY, é amplo, abrangendo leis, inclusive anteriores à Constituição em vigor, e outros atos públicos ou decorrentes do exercício de atividade pública:

"Pode ser ato comissivo ou omissivo, de caráter geral (lei ou ato normativo) ou particular, oriundo da autoridade ou órgão do Poder Público federal, estadual, distrital ou municipal, tanto da administração direta (União, Estados, DF e Municípios) como da indireta (autarquias, sociedades de economia mista, empresas públicas, fundações públicas e agências 
reguladoras) ou dos particulares no desempenho de atividade estatal, seja por concessão, seja por autorização do Poder Público.”243

A inconstitucionalidade pode alcançar apenas parte do dispositivo impugnado. Nesse caso, o requerente deverá indicar claramente a parte do dispostivo ou dos dispositivos que pretende seja declarada inconstitucional.

Na hipótese de pedido de interpretação conforme a Constituição (declaração de constitucionalidade da norma, desde que entendida em conformidade com a interpretação fixada no acórdão, excluídas as demais hipóteses interpretativas), deve haver indicação de maneira inequívoca da interpretação que se pretende fixar e a demonstração da inconstitucionalidade das demais interpretações possíveis de serem extraídas do dispositivo, de modo a permitir que o tribunal fixe determinado sentido a ser extraído da norma com vista a reconhecer sua constitucionalidade e, em consequência a inconstitucionalidade parcial qualitativa.

Há quem identifique a exigência da menção a fatos na petição inicial do processo comum (CPC, art. 282, III, isto é, a causa de pedir remota) à prescrição de indicação do dispositivo legal no processo da ação direta de inconstitucionalidade: “O fato na petição inicial da ADI, é o dispositivo da lei ou do ato normativo impugnado, ou seja, aquele que o autor entende contrariar a Constituição.”244

Permissa venia, não me parece que o dispositivo de lei ou ato normativo impugnado corresponda ao fato mencionado no inc. III, do artigo 282 do Código de Processo Civil que, ao disciplinar os requisitos da petição inicial, inclui, dentre eles, "o fato e os fundamentos jurídicos do pedido”.

Pode, eventualmente, ocorrer que no processo de formação da lei haja um determinado vício (projeto de lei complementar aprovado por maioria simples, $v$.

\footnotetext{
243 NERY JÚNIOR, Nelson; NERY, Rosa Maria De Andrade. Constituição Federal anotada e legislação constitucional. São Paulo, Revista dos Tribunais, 2006, p. 581.

${ }^{244}$ BARBOSA SOBRINHO, Osório Silva. Comentários à Lei n. 9.868/99: Processo do controle concentrado de constitucionalidade. São Paulo, Saraiva, 2004, p. 11.
} 
g., a configurar uma inconstitucionalidade formal, por vício no processo legislativo), que demande a prova de fatos específicos. Aí sim, poder-se-ia falar em fatos constitutivos do pedido, que precisam ser necessariamente provados. ${ }^{245}$

É possível, por outro lado, admitir que a narrativa da aprovação, promulgação e publicação de um ato normativo que se pretenda ver declarado inconstitucional equivaleria ao fato exigido como requisito da petição inicial pela legislação processual civil, configurando-se como causa de pedir remota das ações de controle abstrato de constitucionalidade.

Aprofundarei o exame da matéria em tópico próprio, concernente ao princípio da especificação das normas, item 3.2.4, infra.

\subsubsection{Os fundamentos jurídicos do pedido em relação a cada uma das especificações (art. $3^{\circ}, I$, in fine (ADI), art. 14, $I$, in fine (ADC)}

Comentarei esse requisito em tópico próprio: o princípio da especificação das normas, item 3.2.4, infra.

\footnotetext{
245 Pondera ANDRÉ RAMOS TAVARES que: “O afastamento da apreciação dos fatos tem-se tornado verdadeiro dogma do processo constitucional objetivo. Contudo, tem-se questionado referido entendimento, porque os fatos são inafastáveis em certas verificações da constitucionalidade, ingressando como elementos necessários para se alcançar uma solução. Realmente, uma análise em abstrato da constitucionalidade dos atos estatais, ainda que restrito fosse o controle judicial da constitucionalidade dos atos normativos, não pode, jamais, situar-se apenas no campo teórico, sem referência ao mundo dos fatos. Não seria necessário ir muito longe para provar o acerto dessa assertiva. Bastaria olhar para os casos de inconstitucionalidade formal, por vício do processo legislativo, para perceber que, em tal hipótese, o que se compara é a materialidade dos fatos (do processo legislativo efetivamente realizado) com a norma material que regula constitucionalmente esse processo. A norma em si mesma considerada é, antes de mais nada, um ato derivado do mundo concreto e nele presente de maneira indeclinável.” In: TAVARES André Ramos. Tratado da argüição de descumprimento de preceito fundamental. São Paulo, Saraiva, 2001, p. 278-279.
} 


\subsubsection{A prova da violação do preceito fundamental na ADPF (Lei federal $\mathbf{n}^{0}$ 9.882/99, art $3^{\circ}$, III)}

Em virtude de tratar-se de ação sumária, de rito especial, tal qual o mandado de segurança, a arguição de descumprimento de preceito fundamental requer a prova pré-constituída da violação ao preceito fundamental. De fato, como bem esclarece CELSO RIBEIRO BASTOS:

"Da leitura do disposto no art. $3^{\circ}$ da legislação surge a necessidade de que, tal como ocorre no mandado de segurança, haja a comprovação de plano do suposto descumprimento de preceito fundamental por ato do poder público. A lei fala expressamente na 'prova da violação do preceito fundamental' (inciso III) como uma das condições da ação."”46

Se o documento necessário à propositura da ação não se encontra em poder do requerente, este poderá requerer ao relator da ação que determine à autoridade pública, ao órgão público ou ao particular que esteja de posse do documento que o envie a juízo para a análise do pedido. ${ }^{247}$

\subsubsection{O pedido, com suas especificações [art. $3^{\circ}$, II (ADI) e art. 14, II (ADC), da Lei federal $n^{\circ}$ 9.868/99; e art. $3^{\circ}$, IV, da Lei federal $n^{\circ}$ 9.882/99 (ADPF)]}

A prática do controle de constitucionalidade perante as Constituições de 1946 (após a EC 16/65) e de 1967/1969 revela que o Procurador-Geral da República tinha a possibilidade de propor a ação sem a formulação de pedido explícito de declaração de inconstitucionalidade (RTJ 166-3).

\footnotetext{
${ }^{246}$ BASTOS, Celso Ribeiro. Arguição de descumprimento de preceito fundamental e legislação regulamentadora. In: TAVARES, André Ramos; ROTHENBURG, Walter Claudius (orgs.). Arguição de descumprimento de preceito fundamental: análises à luz da Lei no 9.882/99. São Paulo, Atlas, 2001, p. 81.

${ }^{247}$ Nesse sentido, veja-se NERY JUNIOR, Nelson; NERY, Rosa Maria Andrade. Constituição Federal anotada e legislação constitucional. São Paulo, Revista dos Tribunais, 2006, p. 581.
} 
Mesmo perante a Constituição de 1988, MARTINS e MENDES, trazem precedente no qual o Procurador-Geral da República formulou pedido incompleto, solicitando que, “obtidas as informações da Assembléia Legislativa fluminense e ouvido o Advogado-Geral da União, seja aberta vista ao Autor para a sua manifestação definitiva sobre o mérito da ação" ${ }^{248}$, não tendo o Supremo Tribunal deixado de conhecer da ação por esse motivo, que chegou a julgamento de mérito.

Na ação direta de inconstitucionalidade 47-SP, da qual foi relator o Ministro OCTAVIO GALLOTTI, o Procurador-Geral da República também solicitou que, uma vez instruído o processo com as informações cabíveis, o processo fosse encaminhado àquele órgão para a emissão de parecer sobre o mérito da arguição de inconstitucionalidade. ${ }^{249}$ Em suas informações, o Governador do Estado apresentou preliminar de extinção do processo por falta de pedido explícito do requerente, que foi, todavia, desacolhida pelo Tribunal. ${ }^{250}$

Como, atualmente, e em meu entender de forma salutar, as leis que regulam as ações de controle abstrato exigem expressamente a formulação do pedido, com suas especificações, o pedido incompleto mostra-se inaceitável. A não formulação do pedido ou a sua formulação incompleta podem levar à inépcia da inicial.

\footnotetext{
248 MARTINS, Ives Gandra da Silva; MENDES, Gilmar Ferreira. Controle concentrado de constitucionalidade. $3^{\text {a }}$ ed., São Paulo, Saraiva, 2009, p. 274. O precedente refere-se à ADI 613/DF, Rel. Ministro FRANCISCO REZEK.

${ }^{249}$ ADI 47/SP. Relator: Ministro OCTAVIO GALLOTTI. Julgamento: 22/10/1992. Tribunal Pleno. Publicação: DJ 13-06-1997, pp. 26688. Ement. vol. 01873-01, p. 01. RTJ 166, p. 03.

${ }^{250}$ ADI 47/SP. Relator: Ministro OCTAVIO GALLOTTI. Julgamento: 22/10/1992. Tribunal Pleno. Publicação: D. J. 13-06-1997, p. 26688. Ement. vol. 01873-01, p. 01. RTJ 166, p. 03. Em seu voto, o Ministro GALLOTTI assim se pronunciou acerca da preliminar: "Rejeito a preliminar de extinção do processo, por falta de pedido explícito do requerente. Quando se haja o Procurador-Geral, expressa e frontalmente manifestado, na inicial, pela constitucionalidade do dispositivo, já decidiu o Tribunal não ser o caso de se conhecer do pedido (cfr. Acórdão na Rep. 1349, D. J. de 10-8-89. O mesmo não sucede quando o Autor, sem sustentar a improcedência da ação direta, apenas se reserva para opinar após as informações (Rp. 1.451, RTJ 127/789). É certo que, após os precedentes citados, a Constituição de 1988 (art. 103) ampliou a titularidade da antiga representação, agora denominada ação direta, antes de iniciativa privativa do Procurador-Geral da República. Mas, pelo menos quanto a este, parece inegável subsistir a prerrogativa de reservar-se a opinar, a final, sobre a constitucionalidade, ou não, da norma impugnada, visto que a Lei Fundamental, a par da legitimidade para a propositura da ação, estabeleceu a sua obrigatória audiência no feito (art. 103, $\S 1^{\circ}$ ), a tornar claro, penso eu, que o simples ajuizamento da causa, pelo Chefe do Ministério Público Federal, não induz, necessariamente, à manifestação de um juízo definitivo sobre a inconstitucionalidade do dispositivo atacado.” In: RTJ 166, p. 10.
} 
Por outro lado, também não merecem acolhimento os pedidos omissos ou genéricos. O Supremo Tribunal Federal não tem admitido a impugnação genérica e abstrata de dispositivos, desvinculada da indicação de fatos e fundamentos jurídicos do pedido. Neste sentido, a seguinte ementa, cujo V. Acórdão foi relatado pelo Ministro MAURÍCIO CORREA:

"EMENTA: AÇÃO DIRETA DE INCONSTITUCIONALIDADE. IMPUGNAÇÃO ABSTRATA E GENÉRICA DE LEI COMPLEMENTAR. IMPOSSIBILIDADE DE COMPREENSÃO EXATA DO PEDIDO. NÃO CONHECIMENTO. 1. Argüição de inconstitucionalidade de lei complementar estadual. Impugnação genérica e abstrata de suas normas. Conhecimento. Impossibilidade. 2. Ausência de indicação dos fatos e fundamentos jurídicos do pedido com suas especificações. Não observância à norma processual. Conseqüência: inépcia da inicial. Ação direta não conhecida. Prejudicado o pedido de concessão de liminar."251

A definição do pedido omisso ou genérico é fornecida por JULIANO TAVEIRA BERNARDES:

\begin{abstract}
"Dessarte, os pedidos omissos ou genéricos quanto à delimitação do questionamento da disposição (rectius, preceito) não merecem conhecimento. Pedido omisso é o carecedor de indicação do preceito questionado. O órgão julgador não consegue identificar a que preceito correspondem as causas de pedir formuladas. Pedido genérico é o que não permite saber, entre os preceitos questionados, a qual se refere a fundamentação. Incluem-se aí, por extensão, os casos em que os preceitos, apesar de delimitados, vieram relacionados a motivações feitas por amostragem. Todavia, o fato de a motivação ser genérica não induz a que o pedido assim se considere. Basta que a fundamentação seja em tese suficiente à obtenção da procedência do pedido em relação a todos os preceitos questionados." 252
\end{abstract}

\footnotetext{
${ }^{251}$ ADI 1775/RJ-RIO DE JANEIRO, Relator: Min. MAURÍCIO CORRÊA. Julgamento: 06/05/1998. Órgão Julgador: Tribunal Pleno. Publicação: DJ 18-05-2001, PP-00431, EMENT VOL-02031-03 PP-00532. No mesmo sentido, a seguinte decisão monocrática: "Trata-se de ação direta de inconstitucionalidade ajuizada pelo Sindicato dos Empregados em Estabelecimentos de Saúde de São José dos Campos e Região, em que se busca a invalidação do 'inciso I do artigo 83 da Nova Lei de Falências (Lei ordinária no 11.101, de 09/02/2005)' (fl. 02). A entidade sindical autora não indica as normas constitucionais supostamente violadas, nem desenvolve nenhum tipo de fundamentação de suas razões, limitando-se, apenas, a formular pedido genérico de invalidação jurídicoconstitucional da norma impugnada.” In: ADI 3683/SP-SÃO PAULO. Relator: Min. RICARDO LEWANDOWSKI. Julgamento: 05/04/2006. Publicação: DJ 20/04/2006, PP-00038. E, ainda: ADI 2561/MGMINAS GERAIS. Relator: Min. EROS GRAU. Julgamento: 15/12/2004. Publicação: DJ 01/02/2005, PP-00073.

${ }^{252}$ BERNARDES, Juliano Taveira. Controle abstrato de constitucionalidade: Elementos materiais e princípios processuais. São Paulo, Saraiva, 2004, p. 405-406.
} 
Costuma-se desdobrar o pedido em mediato e imediato, consubstanciando-se o primeiro como o bem da vida perseguido e o segundo como a providência jurisdicional solicitada. Nesse sentido, nas ações de controle abstrato de constitucionalidade, o pedido imediato consistiria na declaração de inconstitucionalidade ou de constitucionalidade. O pedido mediato, por sua vez, consistiria na segurança jurídica abstratamente considerada.

\subsection{Necessidade de impugnação de todo o complexo normativo referente ao dispositivo que se pretende declarar inconstitucional}

Outra hipótese de pedido incompleto é aquela onde o autor da ação direta deixar de impugnar todos os dispositivos ou todas as leis que formam um complexo normativo. Dessa forma, se a lei $A$ e a lei $B$ regulam determinada matéria, a impugnação deve recair sobre ambas, caso contrário, a declaração de inconstitucionalidade não surtiria efeito prático algum e, por esse motivo, o autor seria carecedor de ação, por falta de interesse de agir (CPC, art. 267, VI).

De fato, o interesse de agir se expressa no binômio necessidade da tutela jurisdicional e adequação do meio utilizado para obtê-la e poderia ser resumido na utilidade da tutela pleiteada. No caso do pedido incompleto, ainda que haja a necessidade da tutela almejada (declaração de inconstitucionalidade), ela não se revestiria de nenhuma utilidade, pois a declaração parcial não se prestaria a sanar a inconstitucionalidade, em virtude de permanecerem válidas normas análogas àquela cujo vício foi arguido.

O pedido nesta hipótese revela-se incompleto e, por isso, inábil a alcançar o objetivo almejado pelo autor.

Como se exige que a parte provoque a jurisdição (princípio da demanda), se esta, ao provocá-la, o faz de maneira parcial, sem atacar a totalidade dos 
dispositivos que regulam a matéria, o tribunal não pode estender a prestação jurisdicional às demais normas ou dispositivos, motivo pelo qual a tutela não pode ser prestada pela corte constitucional.

O Supremo Tribunal Federal tem entendido que a impugnação de determinadas normas de um sistema, indissociavelmente ligadas a outras que não foram impugnadas via ação direta impediria o acolhimento do pedido, pois, se fosse acolhido, poderia implicar em remanescer no texto legal uma dicção indefinida, assistemática, imponderável e inconsequente. Assim, em decorrência de o tribunal não poder exercer ex officio a jurisdição, não tem como incluir no objeto da ação outras normas indissoluvelmente ligadas às impugnadas, mas não suscitadas pelo requerente. Nesse sentido, há casos em que não se conhece da ação direta de inconstitucionalidade pelas razões expostas, não obstante se ressalve a possibilidade de propositura de nova ação que impugne todo o sistema. ${ }^{253}$

Em ação direta proposta contra lei destinada à desoneração de ICMS sobre determinadas situações, que previa, igualmente, a compensação dos Estadosmembros em decorrência dessa desoneração, por determinado período, o requerente atacou apenas os dispositivos que tratavam da desoneração. O Supremo Tribunal Federal, em acórdão relatado pelo Ministro NELSON JOBIM, não conheceu da ação, pois se o pedido restringia-se aos dispositivos que tratavam da desoneração, não poderia o tribunal ex officio estendê-lo aos demais, referentes à compensação a ser repassada pela União aos Estados, que não poderiam, logicamente, ser mantidos dissociados dos outros. ${ }^{254}$

\section{Na ADI-MC 2645-QO, o Ministro SEPÚLVEDA PERTENCE} não conheceu da ação em virtude de o pedido de inconstitucionalidade parcial do dispositivo atacado levar a uma hipótese em que, se declarada a inconstitucionalidade, a norma, que

\footnotetext{
${ }^{253}$ Neste sentido, veja-se a ADI 1187/DF. Relator: Ministro MAURÍCIO CORRÊA. Julgamento: 27/03/1996. Órgão Julgador: Tribunal Pleno. Publicação: D. J.: 30-05-1997, pp. 23175, Ement. vol. 01871-01, p. 0192.

${ }^{254}$ Trata-se da ADI 1622/DF. Relator: Ministro NELSON JOBIM. Julgamento: 30/10/1997. Órgão Julgador: Tribunal Pleno. Publicação: D. J.: 17-04-1998., pp. 02. Ement. vol. 01906-01, pp. 0127, cuja ementa tem o seguinte teor: "EMENTA: AÇÃO DIRETA DE INCONSTITUCIONALIDADE. LEI COMPLEMENTAR N" 87, DE 13 DE SETEMBRO DE 1.996. ICMS. INCIDÊNCIA. PRODUTOS SEMI-ELABORADOS. PEDIDO INCOMPLETO. ATACA PARTE DOS DISPOSITIVOS. PERDAS. SILENCIA QUANTO À COMPENSAÇÃO. IMPOSSIBILIDADE DE EXTENSÃO PELO STF. Ação Direta não conhecida.”
} 
visava proteger determinada classe de servidores públicos, passaria a ter efeito contrário, prejudicando-os, de modo a subverter “a função de legislação exclusivamente negativa que o poder abstrato de controle abstrato de constitucionalidade outorga ao Tribunal”. ${ }^{255}$

Nesse caso, tendo em vista a impossibilidade de cisão das normas, o Tribunal tem entendido que o pedido inicial revela impossibilidade jurídica - ou, mais propriamente, falta de interesse de agir -, pois, ao declarar a inconstitucionalidade, restaria no ordenamento jurídico uma norma com sentido diverso do original, conferindo ao Tribunal uma postura de legislador ativo, que a Constituição não lhe atribuiu. ${ }^{256}$

A única exceção a esta regra seria a inconstitucionalidade consequencial ou por arrastamento, que será verificada a seguir (item 3.2.5, infra, o princípio da congruência).

\footnotetext{
${ }^{255}$ ADI-MC 2645-QO, D. JO. 29.09.2006, Ement. no 2249-3, Tribunal Pleno.

${ }^{256}$ Ainda exigindo a impugnação de todo o complexo normativo, podem ser mencionados os seguintes julgados: ADI 2133, Relator Ministro ILMAR GALVÃO Julgamento: 09/03/2000, Tribunal Pleno. Publicação: DJ 04-052001, p. 02. Ement. vol. 02029-01, p. 0194. RTJ vol. 178-01, p. 0194; ADI $n^{\circ}$ 1187, Relator Ministro MAURÍCIO CORRÊA Julgamento: 27/03/1996, Tribunal Pleno. Publicação: D. J.: 30-05-1997, p. 23175. Ement. vol.: 01871-01, p. 0192; ADI no 4036, relator Ministro CARLOS BRITTO Publicação: DJe 095, divulg. 22/05/2009. Publicação: 22/05/2009; e ADI $n^{0}$ 4043, relator Ministro EROS GRAU, que possui a seguinte ementa: "COMPLEXO NORMATIVO: O artigo 98 da Lei complementar n. 412 do Estado de Santa Catarina, não questionado, tem evidente correlação com o objeto da presente ação direta. A jurisprudência desta Corte é firme no tocante à imprescindibilidade de impugnação dos textos normativos que cuidem da mesma matéria atacada na ação direta. A demanda não pode atacar apenas um dos atos contidos no complexo normativo. $\mathrm{O}$ sistema de leis vinculadas a determinado tema deve ser questionado em sua íntegra. A razão disso reside no fato de a eficácia da declaração de inconstitucionalidade alcançar tão somente o ato impugnado e não o complexo no qual inserido. Nesse sentido: a ADI n. 2.174, Relator o Ministro Maurício Corrêa, DJ de 7-3-03; a ADI n. 1.187, Relator o Ministro Maurício Corrêa, $D J$ de 30-5-97; a ADI n. 2.133, Relator o Ministro Ilmar Galvão, DJ de 9-300; a ADI n. 2.451, Relator o Ministro Celso de Mello, DJ de $1^{\circ}-8-01$; a ADI n. 2.972, Relator o Ministro Carlos Britto, DJ de 29-10-03; e a ADI n. 2.992, Relator Ministro Eros Grau, DJ de 17-12-04. Não conheço desta ação direta [RISTF, artigo 21, § $1^{\circ}$ ].” In: ADI 4.043, Rel. Min. Eros Grau, decisão monocrática, julgamento em 3-309, DJE de 11-3-09).
} 


\subsection{Impugnação de todo o complexo normativo e o direito revogado}

No pedido da ação direta, a melhor técnica indica que o requerente, ao impugnar todo o complexo normativo referente à matéria, deve fazer menção, inclusive, às normas revogadas que tratam da matéria, de modo igualmente inconstitucional.

De fato, se se pretende a declaração de inconstitucionalidade de uma norma $A$ que revogou a norma $B$, por tratar da mesma matéria de maneira idêntica ou análoga, uma vez declarada a inconstitucionalidade da lei $A$ - invalidação esta que inclui o dispositivo ou o efeito revocatório da legislação anterior -, a lei anterior $B$ teria sua vigência restabelecida, de modo a manter em vigor a inconstitucional disciplina da matéria. Nenhum efeito prático teria, portanto, a declaração de inconstitucionalidade da lei $A$.

Dessa forma, "na delimitação inicial do sistema normativo, o requerente deve verificar a existência de normas revogadas que poderão ser eventualmente repristinadas pela declaração de inconstitucionalidade das normas revogadoras. Isso implica, inclusive, a impugnação de toda a cadeia normativa de normas revogadoras e normas revogadas, sucessivamente”. 257

Evita-se, dessa forma, a ocorrência do efeito repristinatório ${ }^{258}$ indesejado.

Neste sentido, veja-se a decisão do Ministro CELSO DE MELLO, culminando pela inviabilidade da ação em decorrência da ausência de impugnação de toda da cadeia normativa, incluídas aí as normas já revogadas, que tratavam da mesma matéria:

257 MARTINS, Ives Gandra da Silva; MENDES, Gilmar Ferreira. Controle concentrado de constitucionalidade: Comentários à Lei n. 9.868, de 10-11-1999. 3ª ed., São Paulo, Saraiva, 2009, p. 279.

${ }^{258}$. Vide nota $\mathrm{n}^{\circ} 128$, supra. 
"Desse modo, considerados os precedentes referidos, e ausente a cumulação de pedidos sucessivos (declaração de inconstitucionalidade da norma superveniente + declaração de inconstitucionalidade da norma anterior por ela revogada), torna-se incognoscível a presente ação direta, pois, seja do deferimento de medida cautelar, seja da eventual declaração de inconstitucionalidade do ato normativo editado em momento subseqüente, resultará, no caso, efeito repristinatório indesejado, pertinente ao diploma revogado, o qual - segundo a própria autora (fls.6/7) - acha-se igualmente impregnado do vício da ilegitimidade constitucional.

$\mathrm{O}$ caso ora em exame registra situação idêntica à constatada na ADI 2.132-RJ e na ADI 2.242-DF, Rel. Min. MOREIRA ALVES, pois a autora da presente ação, não obstante o efeito repristinatório precedentemente mencionado, deixou de formular, em caráter subsidiário, pedido de declaração de inconstitucionalidade referente ao art. 33, IV, e respectivo $\S 4^{\circ}$, da Lei estadual $n^{\circ} 7.551 / 77$, na redação dada pela Lei n. 11.630/99, ambas expressamente revogadas pela edição superveniente da Lei Complementar estadual $n^{\circ}$ 28/2000, cujas normas constituem o único objeto de impugnação nesta sede de fiscalização concentrada. [...]

Sendo assim, considerando as razões expostas, não conheço da presente ação direta de inconstitucionalidade, restando prejudicada, em conseqüência, a apreciação do pedido de medida cautelar."259

\subsection{Modulação de efeitos}

Outrossim, se o requerente ou o requerido pretendem a modulação dos efeitos temprorais da eficácia da decisão proferida na ação direta, deve haver formulação expressa nesse sentido no pedido.

De fato, tendo em vista, como mencionado anteriormente, que a regra em termos dos efeitos da decisão de controle abstrato é a de retroação completa, desde a edição da lei (efeitos ex tunc), eventual pedido de modulação dos efeitos deve ser expressamente formulado na petição inicial. O Supremo Tribunal Federal tem entendido que a

${ }^{259}$ ADI 2215/PE, Relator Ministro CELSO DE MELLO. Decisão monocrática publicada no DJ nº 81, do dia 26/04/2001 (grifos no original). 
ausência de formulação de pedido neste sentido inviabiliza que o tema seja suscitado em sede de embargos de declaração. ${ }^{260}$

\subsection{Aditamento do pedido}

Por fim, resta saber se seria possível o aditamento do pedido em ações de controle abstrato de constitucionalidade.

O Código de Processo Civil, em seu art. 294 dispõe que “Antes da citação, o autor poderá aditar o pedido, correndo à sua conta as custas acrescidas em razão dessa iniciativa”. Verifica-se, assim, que, uma vez estabilizada a relação processual, mediante a citação do réu, mostra-se impossível o aditamento do pedido. Até aquele momento, por outro lado, é possível o aditamento, sofrendo o autor as eventuais custas daí decorrentes.

Entendo que tal regra seja perfeitamente aplicável ao processo de controle abstrato, não havendo nesse caso nenhum óbice em sua inserção no processo especial. O aditamento do pedido seria possível até o momento da requisição das informações, momento correspondente à citação no processo comum; uma vez requisitadas as informações, não seria conveniente a modificação do pedido, em virtude de já ter ocorrido a estabilização

\footnotetext{
260 Neste sentido, veja-se a seguinte ementa de julgado: "CONTROLE CONCENTRADO DE CONSTITUCIONALIDADE - PROCEDÊNCIA DA PECHA DE INCONSTITUCIONAL - EFEITO - TERMO INICIAL - REGRA X EXCEÇÃO. A ordem natural das coisas direciona no sentido de ter-se como regra a retroação da eficácia do acórdão declaratório constitutivo negativo à data da integração da lei proclamada inconstitucional, no arcabouço normativo, correndo à conta da exceção a fixação de termo inicial distinto. EMBARGOS DECLARATÓRIOS - OMISSÃO - FIXAÇÃO DO TERMO INICIAL DOS EFEITOS DA DECLARAÇÃO DE INCONSTITUCIONALIDADE - RETROATIVIDADE TOTAL. Inexistindo pleito de fixação de termo inicial diverso, não se pode alegar omissão relativamente ao acórdão por meio do qual se concluiu pelo conflito do ato normativo autônomo abstrato com a Carta da República, fulminando-o desde a vigência. MUNICÍPIOS - PARTICIPAÇÃO NA ARRECADAÇÃO DO IMPOSTO SOBRE CIRCULAÇÃO DE MERCADORIAS E SERVIÇOS - INCONSTITUCIONALIDADE DE LEI ESTADUAL - ALCANCE DA DECLARAÇÃO. A ofensa frontal da lei do Estado à Constituição Federal implicou, no julgamento ocorrido, o afastamento retroativo à data do surgimento de eficácia do ato impugnado.” In: ADI 2728 ED/AMAMAZONAS. Relator: Min. MARCO AURÉLIO. Julgamento: 19/10/2006. Órgão Julgador: Tribunal Pleno. Publicação: DJe-117. DIVULG. 04-10-2007. PUBLIC. 05-10-2007. DJ 05-10-2007, PP-00021, EMENT. VOL02292-01, PP-00074. RTJ VOL-00202-02, PP-00516.
} 
do processo. Excepcionalmente, diante de fundada motivação no sentido da necessidade do aditamento do pedido, poder-se-ia admiti-lo após a requisição de informações, abrindo-se, necessariamente, prazo para novas informações. ${ }^{261}$

\section{Já decidiu o Supremo Tribunal Federal ${ }^{262}$, analisando} especificamente a aplicabilidade em ação direta de inconstitucionalidade do art. 294 do Código de Processo Civil, embora à época do julgado (01 de março de 1991), a sua redação fosse diversa da atual, conferida pela Lei $\mathrm{n}^{0}$ 8.718, de 14 de outubro de 1993, pela sua aplicação subsidiária ao processo objetivo. 263264

${ }^{261}$ A admitir o aditamento, determinando posterior oitiva dos órgãos responsáveis pela edição da norma, veja-se o seguinte julgado: "Pedido de aditamento da inicial após inclusão em pauta da ação para julgamento final pelo rito do artigo 12 da Lei 9.868/1999. Admissão do aditamento, tendo em vista a irrelevância das alterações promovidas no texto normativo impugnado. Admitido o aditamento, necessária é a abertura de prazo para a manifestação dos requeridos.” In: ADI 3.434-MC, Rel. Ministro JOAQUIM BARBOSA, julgamento em 23-8-06, DJ de 28-9-07.

${ }^{262}$ Trata-se da ADI 437-QO, Rel. Ministro CELSO DE MELLO, Ementário nº 1692-1, D.J. de 19.02.93, Tribunal Pleno, com a seguinte ementa: “AÇÃO DIRETA DE INCONSTITUCIONALIDADE - QUESTÃO DE ORDEM - PETIÇÃO INICIAL - ADITAMENTO - REQUISIÇÃO DE INFORMAÇÕES JÁ ORDENADA IMPOSSIBILIDADE - PEDIDO INDEFERIDO. [...] Com a requisição de informações ao Órgão de que emanou a lei ou ato normativo argüido de inconstitucional opera-se a preclusão do direito, reconhecido ao autor da ação direta de inconstitucionalidade, de aditar a petição inicial.”

${ }^{263}$ Do voto do Ministro CELSO DE MELLO extrai-se o seguinte trecho: "Com o ajuizamento da ação direta de inconstitucionalidade, instauram-se, perante o Supremo Tribunal Federal, relações processuais objetivas, cuja disciplina formal está definida no Regimento Interno desta Corte, a que se aplicam, subsidiariamente, as normas inscritas no Código de Processo Civil. Não se revela, em princípio, inviável a redução da ação direta de inconstitucionalidade às categorias básicas existentes do processo civil, não obstante as nítidas diferenças existentes - e já proclamadas por esta própria Corte - entre o procedimento judicial comum e o processo de controle concentrado de constitucionalidade. A processualização da ação direta e das formas rituais que se lhe aplicam constitui, na realidade, até mesmo em obséquio à unidade fundamental do processo, um mínimo indispensável à própria disciplina da fiscalização abstrata dos atos normativos.” In: ADI no 437-QO, Rel. Ministro CELSO DE MELLO, Ementário n ${ }^{\circ}$ 1692-1, D.J. de 19.02.93.

${ }^{264}$ Veja-se também a ADI 1.775/RJ, Rel. Min. MAURÍCIO CORRÊA, Publicação: D.J.: 18-05-2001, pp. 431, Ementário vol. 02031-03, pp. 00532 (RTJ 177/669), na qual houve proposta de se possibilitar a emenda da inicial, rejeitada pelo Plenário. Do voto do Ministro CARLOS VELLOSO extraiu-se o seguinte trecho: "O eminente Ministro Marco Aurélio entende que aqueles que vêem deficiência na inicial deveriam ensejar à parte a oportunidade de retificá-la ou aditá-la. Essa observação, entretanto, não seria possível, dado que as informações já estão nos autos. No processo objetivo da ação direta, a integração da parte requerida, do autor da lei, ou do ato normativo impugnado, se faz não pela citação comum, mas pelo ofício que requisita as informações, o que já ocorreu. De modo que teria aplicação, no caso, a disposição inscrita no art. 264 do CPC, a dizer que, feita a citação, é defeso ao autor modificar o pedido ou a causa de pedir, sem o consentimento da parte contrária. É o caso, já que as informações estão nos autos. Sob o ponto de vista prático - e há pouco comentávamos, o Ministro Octavio Gallotti e eu, na bancada - é muito mais fácil, muito melhor, formular uma petição inicial do que fazer um aditamento. O Tribunal não está impedindo venha o autor com uma nova ação, em que a causa de pedir, o fato ou conjunto de fatos suscetíveis de produzir, por si, o efeito jurídico pretendido pelo autor, estejam convenientemente expostos na inicial”. 
No caso de medida provisória reeditada ou transformada em lei, o Supremo Tribunal Federal tem exigido o aditamento do pedido, de modo a incluir o novo ato normativo, sob pena de extinção do processo sem apreciação de mérito. ${ }^{265}$ No caso de manutenção exata do texto, essa exigência se mostra de rigor excessivo e desnecessária, com a devida vênia.

\subsubsection{A existência de controvérsia judicial relevante sobre a aplicação da disposição objeto da ação declaratória de constitucionalidade (Lei federal $n^{\circ}$ 9.868/99, art. 14, III)}

Trata-se de exigência específica da ação declaratória de constitucionalidade, a exigir a demonstração da controvérsia judicial relevante acerca da disposição objeto da ação.

Fala-se, neste caso, de legitimação para agir em concreto, relacionado com um estado de incerteza, que põe em cheque a presunção de constitucionalidade da lei. ${ }^{266}$

A insegurança acerca da constitucionalidade da lei pode decorrer de decisões conflitantes proferidas pelos juízos ordinários acerca da constitucionalidade de determinada norma ${ }^{267}$, mas poder-se-ia perquirir também o seu

\footnotetext{
265 “A jurisprudência predominante do Supremo Tribunal Federal tem assentado o entendimento de que a falta de aditamento da inicial, diante de reedição da medida provisória impugnada, ou de sua conversão em lei, enseja a extinção do processo sem julgamento de mérito.” ADI 3957, Rel. Ministro RICARDO LEWANDOWSKI, decisão monocrática, julgamento em 30-4-08, DJE de 8-5-08.

266 “Ao lado do direito de propositura, há de se cogitar aqui, também, de uma legitimação para agir in concreto, tal como consagrada no direito alemão, que se relaciona com a existência de um estado de incerteza, gerado por dúvidas ou controvérsias sobre a legitimidade da lei. Há de se configurar, portanto, situação hábil a afetar a presunção de constitucionalidade, que é apanágio da lei.” In: MARTINS, Ives Gandra da Silva; MENDES, Gilmar Ferreira. Controle concentrado de constitucionalidade: Comentários à Lei n. 9.868, de 10-11-1999. São Paulo, Saraiva, 2009, p. 417-418.

${ }^{267}$ Neste sentido, veja-se a ADC/DF 8, Relator Ministro CELSO DE MELLO, Julgamento: 13/10/1999, Tribunal Pleno. Publicação: DJ 04-04-2003, p. 038. Ement. vol. 02105-01, p. 01.
} 
cabimento no caso de generalização de decisões contrárias à constitucionalidade da lei. ${ }^{268}$ Nesse último caso, fica abalada a presunção de constitucionalidade da lei, o que me parece suficiente para autorizar o ajuizamento da ADC.

\subsubsection{A comprovação da existência de controvérsia judicial relevante sobre a aplicação do preceito fundamental que se considera violado (Lei federal $\mathrm{n}^{\circ} 9.882 / 99$, art. $3^{\circ}, \mathrm{V}$ )}

A arguição de descumprimento de preceito fundamental pode ser implementada de duas formas: pela via principal (Lei federal $n^{\circ} 9.882 / 99$, art. $1^{\circ}$, caput) ou pela via incidental (arts. $5^{\circ}, \S 3^{\circ}$ e 10 , caput).

O requisito ora em estudo é um requisito específico da arguição de descumprimento de preceito fundamental incidental. O requerente, se for o caso, deve trazer prova da divergência jurisprudencial acerca do preceito fundamental a ser debatido.

Surge desde logo a indagação: quando ocorrerá a necessidade de o requerente comprovar a controvérsia judicial? A responder a questão, assevera TAVARES:

"Certamente que a resposta não pode ser extensiva a todas as hipóteses de argüição incidental. É que sua regra matriz (inc. I do parágrafo único do art. $1^{\circ}$ ) apenas contempla a necessidade de controvérsia constitucional relevante. É em razão disso que o dispositivo ora em comento aponta para a sua aplicabilidade restrita, ao preceituá-la 'se for o caso'. Assim, para responder

\footnotetext{
${ }^{268}$ MARTINS e MENDES criticam o critério que exige um número expressivo de decisões conflitantes, entendendo que: "A questão parece estar a merecer outro enfoque. A exigência quanto à configuração de controvérsia judicial ou controvérsia jurídica (Rechtsstreitigkeit) associa-se não só à ameaça ao princípio da presunção de constitucionalidade - esta independe de um número quantitativamente relevante de decisões de um e de outro lado -, mas também, e sobretudo, na invalidação prévia de uma decisão tomada por segmentos expressivos do modelo representativo. A generalização de decisões contrárias a uma decisão legislativa não inviabiliza - antes recomenda - a propositura de ação declaratória de constitucionalidade. É que a situação de incerteza, na espécie, decorre não da leitura e aplicação contraditória de normas legais pelos vários órgãos judiciais, mas da controvérsia ou dúvida que se instaura entre os órgãos judiciais, que, de forma quase unívoca, adotam dada interpretação, e os órgãos políticos responsáveis pela edição do texto normativo”. In: MARTINS, Ives Gandra da Silva; MENDES, Gilmar Ferreira. Controle concentrado de constitucionalidade: Comentários à Lei n. 9.868, de 10-11-1999. São Paulo, Saraiva, 2009, p. 421-422.
} 
àquela indagação, tem-se que nas hipóteses em que a relevância surge justamente por se haver estabelecido controvérsia judicial no país, sobre questão fundamental, e que se exige a sua prova, o que é feito com a juntada de decisões desencontradas sobre o mesmo tema. Note-se que aqui se está diante da necessidade de prova de relevância, e não da violação do preceito fundamental, exigida no inciso III, do mesmo art. $3^{\circ}$. É que, uma vez provada a relevância, ainda resta a necessidade da prova de que dela deriva violação de preceito fundamental. Não basta, pois, a mera relevância da questão judicial. É preciso que haja, vale insistir, a violação a preceito fundamental.”269

Trata-se de um incidente processual de conhecimento prévio ao da arguição, que deve ser realizado “no próprio juízo de admissibilidade da argüição incidental, sem desmembramentos ulteriores”. ${ }^{270}$

\subsubsection{O princípio da especificação das normas [Lei federal $\mathrm{n}^{0}$ 9.868/99, art. $3^{\circ}$, I, primeira parte (ADI); e art. 14, I (ADC)], ou da indicação do ato questionado [(Lei federal $\mathbf{n}^{\circ}$ 9.882/99, art. $3^{\circ}$, II, (ADPF)]}

O princípio da especificação das normas, extraído da jurisprudência do Supremo Tribunal Federal, reflete o dever atribuído ao requerente de apresentar na petição inicial não só os fundamentos jurídicos, exigidos em todas as espécies de processo (causa de pedir próxima), mas também os dispositivos alegadamente violados pelo ato normativo que se pretende impugnar, isto é, as normas constitucionais de referência que servem de parametricidade para a declaração de inconstitucionalidade.

No processo civil comum, cabe ao autor indicar na petição inicial os fatos e os fundamentos jurídicos do pedido (CPC, art. 282, III), bem como formular o pedido, com as suas especificações (CPC, art. 282, IV), não havendo, desse modo, norma que exija a indicação dos dispositivos legais hábeis a fundamentar a pretensão do autor.

\footnotetext{
${ }^{269}$ TAVARES, André Ramos. Tratado da argüição de preceito fundamental. São Paulo, Saraiva, 2001, p. 418. ${ }^{270}$ Ibidem, p. 425.
} 
Segundo DINAMARCO, fundamentos jurídicos “consistem na demonstração de que os fatos narrados se enquadram em determinada categoria jurídica [...] e de que a sanção correspondente é aquela que o demandante pretende [...]”. ${ }^{271}$

Quando se fala em fatos e fundamentos jurídicos do pedido, refere-se o Código àquilo que a doutrina brasileira costuma denominar de causa de pedir remota e próxima, respectivamente. ${ }^{272}$

Quanto aos fundamentos jurídicos (causa de pedir próxima), cabe ao requerente, na petição inicial, indicar as razões de direito que suportam o seu pedido de declaração de inconstitucionalidade.

No controle abstrato, os fundamentos jurídicos do pedido devem consubstanciar-se na interpretação conferida aos princípios e regras constitucionais, de forma a servir de parâmetro para a aferição da inconstitucionalidade por ação ou omissão ou, no caso da ação declaratória de constitucionalidade, as razões pelas quais as normas infraconstitucionais amoldam-se aos preceitos da Constituição. Vale dizer, o requerente deve mencionar os subsídios jurídicos, as teses, os argumentos de direito aptos a levar o tribunal a reconhecer a inconstitucionalidade ou a constitucionalidade das normas por ele indicadas.

Neste sentido, já há tempo decidiu o Supremo Tribunal Federal:

“É necessário, em ação direta de inconstitucionalidade, que venham expostos os fundamentos jurídicos do pedido com relação às normas impugnadas, não sendo de admitir-se alegação genérica de inconstitucionalidade sem qualquer demonstração razoável, nem ataque a

${ }^{271}$ DINAMARCO, Cândido Rangel. Instituições de Direito Processual Civil, v. II. $6^{\mathrm{a}}$ ed., São Paulo, Malheiros, 2009, p. 132.

272 "Chama-se a atenção para o texto da lei. O Código exige que o autor exponha na inicial o fato e os fundamentos jurídicos do pedido. Por esse modo faz ver que na inicial se exponha não só a causa de pedir próxima - os fundamentos jurídicos, a natureza do direito controvertido -, como também a causa remota - o fato gerador do direito. Quer dizer que o Código adotou a teoria da substanciação, como os códigos alemão e austríaco. Por esta teoria não basta a exposição da causa próxima, mas também se exige a da causa remota”. In: SANTOS, Moacyr Amaral. Primeiras linhas de direito processual civil, v. 1. 26 ed., São Paulo, Saraiva, 2009, p. 172. 
quase duas dezenas de medidas provisórias em sua totalidade com alegações por amostragem."273

Como elucidou o Ministro CELSO DE MELLO, em decisão monocrática pela qual não conheceu de petição inicial de ação direta de inconstitucionalidade:

\begin{abstract}
“Considerada a jurisprudência desta Suprema Corte - que deu causa à formulação da regra inscrita no art. $3^{\circ}$, I, da Lei no 9.868/99 -, não se pode conhecer de ação direta, sempre que a impugnação nela veiculada, como ocorre na espécie, revelar-se destituída de fundamentação ou quando a argüição de inconstitucionalidade apresentar-se precária ou insuficientemente motivada.”274 275
\end{abstract}

O não atendimento deste dever processual pode, portanto, acarretar no indeferimento da petição inicial, inclusive por decisão monocrática do relator. De fato, o Supremo Tribunal Federal "não admite argüiç̧ões de inconstitucionalidade, quando destituídas de fundamentação ou desprovidas de motivação específica e suficientemente desenvolvida”. 276

Ressalte-se, todavia, que a inépcia da inicial só ocorre quando houver uma completa falta de fundamento jurídico. Pois, como adverte o Ministro MOREIRA ALVES, se "houver a invocação de fundamento para a argüição de inconstitucionalidade, ainda que esse fundamento seja errôneo a inicial não é inepta porque a causa petendi aberta nos permite examiná-la em face de todos os dispositivos constitucionais”. ${ }^{277}$

\footnotetext{
${ }^{273}$ ADI 259, Rel. Min. MOREIRA ALVES, julgamento em 11-3-91, DJ de 19-2-93.

${ }^{274}$ ADI 514/PI, Relator Ministro CELSO DE MELLO, decisão publicada no D.J.E. de 31.3.2008, íntegra no Informativo STF no 499.

${ }^{275}$ No mesmo sentido: RTJ 144/690, Relator: Ministro MOREIRA ALVES; ADI 1708/MT, Relator: Ministro MARCO AURÉLIO; e ADI 1811/DF, Relator: Ministro MAURÍCIO CORREA; ADI 561/DF, Relator: Ministro CELSO DE MELLO; ADI 1775/RJ, Relator: Ministro MAURÍCIO CORREA; ADI 2111/DF, Relator: Ministro SYDNEY SANCHES; e ADI-MC 2213/DF, Relator: Ministro CELSO DE MELLO.

${ }^{276}$ ADI 514/PI, Relator Ministro CELSO DE MELLO, decisão publicada no D.J.E. de 31.3.2008, íntegra no Informativo STF $n^{\circ} 499$.

277 ADI 1775/RJ, Rel. Min. MAURÍCIO CORRÊA, Publicação: D.J.: 18-05-2001, pp. 431, Ementário vol. 02031-03, pp. 00532 (RTJ 177/669), voto do Ministro MOREIRA ALVES, p. 574-575.
} 
Mas, se o fundamento for global, a alicerçar a inconstitucionalidade de todos os dispositivos inquinados de invalidade, inexistindo fundamento para inconstitucionalidade de cada dispositivo em particular, como bem esclareceu o Ministro MOREIRA ALVES, não se deve conhecer a ação, pois:

"se o ato normativo não for inconstitucional em face dele (fundamento global), ter-se-á de julgar improcedente a ação, o que implicará a declaração de sua constitucionalidade integral, ainda que dispositivos seus, que não foram atacados em particular com qualquer fundamentação e, portanto, sem causa petendi, possam ser inconstitucionais por fundamentos diversos”. 278

O entendimento do Ministro MOREIRA ALVES assenta-se no caráter dúplice das ações diretas de inconstitucionalidade e declaratória de constitucionalidade, segundo o qual julgada procedente a ação direta de inconstitucionalidade ou improcedente a declaratória de constitucionalidade, declara-se a inconstitucionalidade do dispositivo; e julgada improcedente a ação declaratória de constitucionalidade ou procedente a declaratória de constitucionalidade, declara-se inconstitucional o dispositivo (Lei federal $n^{\circ}$ 9.868/99, art. 24). ${ }^{279}$

Além do dever de trazer os fundamentos jurídicos do pedido, cabe ao requerente, na petição inicial indicar os dispositivos constitucionais alegadamente violados pelo ato normativo que se pretende invalidar, isto é, a norma constitucional que serve de parâmetro para a declaração de inconstitucionalidade.

${ }^{278}$ ADI 1775/RJ, Rel. Min. MAURÍCIO CORRÊA, Publicação: D.J.: 18-05-2001, pp. 431, Ementário vol. 02031-03, pp. 00532 (RTJ 177/669), voto do Ministro MOREIRA ALVES, p. 574-575.

${ }^{279}$ O Ministro SEPÚLVEDA PERTENCE, em voto proferido na AO-QO 166/PB, traz subsídios acerca do entendimento do Supremo Tribunal Federal no tocante ao caráter dúplice das ações de controle concentrado de constitucionalidade, revelando, inclusive, a crítica doutrinária sobre ele incidente: "Sucede, ao contrário da orientação predominante no direito comparado (J. M. Cardoso da Costa, Relatório Geral da VII Conferência dos Tribunais Constitucionais Europeus, nos anais do encontro: Justiça Constitucional - Espécies, Conteúdo e Efeitos das Decisões sobre a Constitucionalidade das Noras, Lisboa, 1987, p. 27, 56) - que, no Brasil - malgrado dissensões doutrinárias (v.g., Elival Ramos, ob. cit., p. 119, que invoca a opinião de O. A. Bandeira de Mello) -, tende a assentar-se a conclusão de que a decisão de mérito do Supremo Tribunal que julga improcedente a ação direta de inconstitucionalidade implica a declaração positiva da constitucionalidade da norma impugnada.” Julgamento: 16/05/2001. Órgão Julgador: Tribunal Pleno. Publicação: D.J.: 06/09/2001, p. 07, Ementário vol. 02042, p. 09 (grifos no original). 
No processo comum, a indicação dos dispositivos de lei é dispensável, pois, como bem esclarece DINAMARCO:

"O fundamento legal - mera indicação dos dispositivos da lei, seus artigos etc. - não integra a causa de pedir e não concorre para individualizar a demanda. Não o exige o inc. III do art. 282 do Código de Processo Civil nem seria razoável que o fizesse. Fundamento legal não é o mesmo que fundamento jurídico.,280

BARBOSA MOREIRA, a reforçar tal entendimento, assevera

que:

"Não integram a causa petendi: a) a qualificação jurídica dada pelo autor ao fato em que apóia sua pretensão (v.g., a referência a 'erro' ou a 'dolo', na petição inicial, para designar o vício do consentimento invocado com causa da pretendida anulação do ato jurídico); b) a norma jurídica aplicável à espécie.”281

Todavia, em sede de controle abstrato, em obséquio ao princípio da especificação das normas, a indicação expressa dos dispositivos constitucionais violados mostra-se necessária, ainda que o tribunal não fique a eles condicionado quando da apreciação da inconstitucionalidade, pois, como esclarecerei adiante, a causa de pedir nos processos objetivos é aberta (item 3.2.5, infra).

A jurisprudência pacífica do Supremo Tribunal Federal exige que a petição inicial de ação de processo objetivo contenha não só a fundamentação jurídica hábil a embasar o pedido de declaração de inconstitucionalidade, como também a especificação das normas-parâmetro constitucionais, ressaltando ser este um dever indeclinável do requerente:

“É certo que o Supremo Tribunal Federal não está condicionado, no desempenho de sua atividade jurisdicional, pelas razões de ordem jurídica invocadas como suporte da pretensão de inconstitucionalidade deduzida pelo

\footnotetext{
${ }^{280}$ Neste sentido, veja-se DINAMARCO, Cândido Rangel. Instituições de Direito Processual Civil, v. II. $6^{\text {a }}$ ed., São Paulo, Malheiros, 2009, p. 133.

${ }^{281}$ BARBOSA MOREIRA, José Carlos. O novo processo civil brasileiro. $27^{\mathrm{a}}$ ed., Rio de Janeiro, Forense, 2009, p. 17.
} 
autor da ação direta. Tal circunstância, no entanto, não suprime à parte o dever processual de motivar o pedido e de identificar na Constituição, em obséquio ao princípio da especificação das normas, os dispositivos alegadamente violados pelo ato normativo que pretende impugnar. Impõe-se ao autor, no processo de controle concentrado de constitucionalidade, indicar as normas de referência - que são aquelas inerentes ao ordenamento constitucional e que se revestem, por isto mesmo, de parametricidade - em ordem a viabilizar a aferição da conformidade vertical dos atos normativos infraconstitucionais.”282 283

Deve, portanto, o autor da ação indicar, de forma específica e individualizada, as normas supostamente inconstitucionais, bem como as razões justificadoras do suposto vício, não se aceitando alegação genérica de ofensa à Constituição ${ }^{284}$, sendo esta técnica procedimental de observância obrigatória em sede de controle abstrato de normas. ${ }^{285}$

Todavia, quando se tratar de inconstitucionalidade formal, revela-se desnecessária a impugnação de cada um dos dispositivos inquinados de vício, pois, nesse caso, em virtude de a inconstitucionalidade não atingir o conteúdo específico dos dispositivos, mas sim a aspectos formais pelos quais foram aprovados, a demonstração da

${ }^{282}$ ADI 561-DF, Relator: Ministro CELSO DE MELLO. Julgamento: 23/08/1995, Tribunal Pleno. D.J. 2303.2001, Ement. vol. 2024-1, pp. 056 (grifos no original).

${ }^{283}$ No mesmo sentido: ADI 2213 MC/DF. Relator: Ministro CELSO DE MELLO. Julgamento: 04/04/2002. Órgão Julgador: Tribunal Pleno, Publicação: DJ 23-04-2004, p. 07, Ement. vol. 02148-02, p. 0296. ADI 514/PI. Relator: Min. CELSO DE MELLO. Julgamento: 24/03/2008. Publicação: DJe-056, Divulg 28/03/2008 PUBLIC 31/03/2008. ADI 2191 MC/AL. Relator: Ministro CELSO DE MELLO. Julgamento: 17/04/2000. Publicação: DJ DATA: 26-04-00, p. 019. ADI n ${ }^{0}$ 588/MT, Relator: Ministro CEZAR PELUSO. Julgamento: 14/04/2008. DJe070, DIVULG.: 17/04/2008. PUBLIC: 18/04/2008. AC n 1383/DF. Relator: Ministra CÁRMEN LÚCIA. Julgamento: 10/11/2006. D.J.: 24/11/2006, pp.091 e ADI no 2394 MC/MG. Relator: Ministro CELSO DE MELLO. Julgamento: 29/06/2001. D.J.: 08/08/2001, p. 4. Vide, outrossim, os Informativos do STF nºs 301 e 499. 284 "Cabe asseverar, por necessário, que nada pode justificar, especialmente em sede de fiscalização normativa abstrata, alegação meramente genérica de ofensa à Constituição, pois incumbe, a quem faz tal afirmação, o dever de indicar, de modo específico e individualizado, as normas supostamente inconstitucionais, bem assim a obrigação de apresentar as razões justificadoras do suposto vício de inconstitucionalidade.” In: ADI n ${ }^{\circ} 2394$ MC/MG. Relator: Ministro CELSO DE MELLO. Julgamento: 29/06/2001. D.J.: 08/08/2001, p.04.

285 "Da leitura e análise da petição inicial, observa-se que o requerente não demonstra quais preceitos dos textos normativos estariam em confronto com a Constituição do Brasil, nem os analisa de forma correlacionada aos artigos constitucionais supostamente violados. Necessário lembrar que a Lei n. 9.868, de 10 de novembro de 1999, preconiza que a peça inaugural das ações diretas indicará o dispositivo da lei ou do ato normativo atacado e os fundamentos jurídicos do pedido em relação a cada uma das impugnações (art. $3^{\circ}$ ). Por não observar essa determinação legal, o requerente deixa de obedecer à técnica imprescindível ao conhecimento da ação. A inicial não se reveste das formalidades a ela inerentes. Enseja a declaração da inépcia da peça por faltar-lhe requisitos essenciais. No caso específico, a exordial não foi elaborada segundo as regras e o estilo constantes em lei própria, destinada a disciplinar o processo e julgamento das ações diretas de inconstitucionalidade. Ao contrário, tem-se pedido genérico e inespecífico.” In: ADI 2.561, Rel. Min. EROS GRAU, decisão monocrática, julgamento em 15-12-04, DJ de $1^{\mathrm{o}}-2-05$. 
inadequação formal alcança todos os dispositivos que passaram pelo mesmo procedimento de aprovação $^{286}$.

\subsubsection{0 princípio da causa de pedir aberta}

No processo civil comum, como mencionado, cabe ao autor especificar na petição inicial os fatos e os fundamentos jurídicos do pedido (CPC, art. 282, III), bem como o pedido, com as suas especificações (CPC, art. 282, IV), sendo defeso ao juiz conhecer de questões não suscitadas a cujo respeito a lei exige iniciativa da parte (art. 128), bem como proferir sentença, a favor do autor, de natureza diversa da pedida e, ainda, condenar o réu em quantidade superior ou em objeto diverso do que lhe foi demandado (art. 460).

É de se ressaltar, todavia, que, mesmo no processo comum, embora seja necessário que o autor exponha na inicial os fundamentos jurídicos do pedido, sob pena de indeferimento, cabe ao juiz conferir aos fatos a qualificação jurídica apropriada (da mihi factum dabo tibi jus).

Isto porque no Brasil adota-se o sistema da substanciação, "pelo qual os fatos narrados influem na delimitação objetiva da demanda e conseqüentemente da sentença (art. 128), mas os fundamentos jurídicos, não”. ${ }^{287}$

Na verdade, a invocação dos fundamentos jurídicos na petição inicial configura uma prévia proposta sugerida ao juiz, a quem compete, em momento oportuno, aplicar os dispositivos legais apropriados para a espécie. ${ }^{288}$

\footnotetext{
286 “É desnecessária a articulação, na inicial, do vício de cada uma das disposições da lei impugnada quando a inconstitucionalidade suscitada tem por escopo o reconhecimento de vício formal de toda a lei.” In: ADI 2.182MC, Rel. Min. MAURÍCIO CORRÊA, julgamento em 31-5-00, DJ de19-3-04.

${ }^{287}$ ADI 2182-MC, Rel. Min. MAURÍCIO CORRÊA, julgamento em 31-5-00, DJ de 19-3-04.

${ }^{288}$ Neste sentido, veja-se o entendimento de CÂNDIDO RANGEL DINAMARCO: “Tratando-se de elementos puramente jurídicos e nada tendo de concreto relativamente ao conflito e à demanda [...], a invocação dos fundamentos jurídicos na petição inicial não passa de mera proposta ou sugestão endereçada ao juiz, ao qual
} 
Tratando-se de processo de controle abstrato de constitucionalidade, a discussão se trava essencialmente em relação à validade das normas, motivo pelo qual, em princípio, caberia ao autor apenas arrolar os fundamentos jurídicos do pedido e especificar as normas-parâmetro, como visto acima. Todavia, muitas vezes, a análise de fatos pode ser útil ou até mesmo imprescindível ao deslinde da questão (essa matéria será examinada adiante, no item referente aos fatos e prognoses legislativas (item 3.2.8.2, infra). Nessas hipóteses, deverá o requerente trazer à tona todos os fatos, documentalmente provados.

No controle abstrato, os fundamentos jurídicos do pedido, como visto, devem consubstanciar-se na interpretação conferida aos princípios e regras constitucionais, de forma a servir de parâmetro para a aferição da inconstitucionalidade por ação ou omissão ou, no caso da ação declaratória de constitucionalidade, as razões pelas quais as normas infraconstitucionais amoldam-se aos preceitos da Constituição.

A Lei Orgânica do Tribunal Constitucional português (Lei 28, de 15 de novembro de 1982) possui disposição que bem expressa o conteúdo do princípio da causa de pedir aberta. Trata-se do art. 51º n. 5, cuja redação é a seguinte:

“Art. 51. ${ }^{\circ}$

(Recebimento e admissão)

[...]

5 - O Tribunal só pode declarar a inconstitucionalidade ou a ilegalidade de normas cuja apreciação tenha sido requerida, mas pode fazê-lo com fundamentação na violação de normas ou princípios constitucionais diversos daqueles cuja violação foi invocada." (grifo nosso)

Verifica-se que o referido artigo da LOTC exige, inicialmente, a provocação da jurisdição constitucional (princípio da demanda ou do pedido), bem como a especificação da norma-parâmetro e, por outro lado, permite expressamente a declaração de

compete fazer depois os enquadramentos adequados - para o que levará em conta a narrativa de fatos contida na petição inicial, a prova realizada e sua própria cultura jurídica, podendo inclusive dar aos fatos narrados e provados uma qualificação jurídica diferente daquela que o demandante sustentara (narra mihi factum dabo tibi jus).” In: DINAMARCO, Cândido Rangel. Instituições de Direito Processual Civil, v. II. $2^{\mathrm{a}}$ ed., São Paulo, Malheiros, 2002, p. 128-129. 
inconstitucionalidade com fundamento em princípios ou normas constitucionais não invocados na inicial (princípio da causa de pedir aberta).

CANOTILHO, ao comentar tal dispositivo, do qual extrai princípio que denomina de princípio da individualização, pondera o seguinte:

\begin{abstract}
“Associada ao princípio dispositivo e ao princípio da congruência e como consequência deles, a doutrina processual civil desenvolveu a regra (hoje relativamente ultrapassada) da correspondência entre o pedido $e$ o pronunciado de acordo com o princípio da substanciação: o juiz conforma-se com a delimitação do tema a decidir feita pelas partes, não lhe competindo averiguar se a pretensão poderia obter-se através de outra providência ou com outros fundamentos jurídicos.

Em todo o seu rigor, o princípio da substanciação conduziria à impossibilidade prática de, por ex., o RC averiguar se, em vez de uma inconstitucionalidade formal, existe uma inconstitucionalidade material ou uma e outra conjuntamente. Nas ações de inconstitucionalidade, é obvio que embora a petição enuncie os fundamentos jurídicos tendentes a demonstrar a existência do vício de inconstitucionalidade, o Tribunal Constitucional aprecia com larga elasticidade (princípio da individualização) a relação de conformidade ou desconformidade das normas impugnadas com 0 parâmetro normativo-constitucional (cfr. LTC, art. 51.\%/5).” 289
\end{abstract}

A esclarecer a amplitude do conceito de causa de pedir aberta, o Ministro CELSO DE MELLO assevera que, em sede de controle abstrato, não basta afirmar que determinada lei é inconstitucional, impõe-se ao autor da ação direta fundamentar, juridicamente, a arguição de inconstitucionalidade, ainda que o Supremo Tribunal Federal, embora condicionado pelo pedido, não esteja vinculado à motivação exposta. ${ }^{290}$

Em outra oportunidade, ressalvou o ilustre Ministro, citando como precedente a ADI 561/DF, por ele mesmo relatada, que “o Supremo Tribunal Federal não está condicionado, no desempenho de sua atividade jurisdicional, pelas razões de ordem

${ }^{289}$ CANOTILHO, Joaquim José Gomes. Direito constitucional e teoria da Constituição. $7^{\mathrm{a}}$ ed., Coimbra, Almedina, 2003, p. 972-973 (grifos no original). Há que se fazer uma ressalva ao entendimento acima exposto, pois o princípio da substanciação, segundo a doutrina abalizada e acima mencionada, vincula o juiz à narrativa dos fatos e não dos fundamentos jurídicos, pois enunciados os fatos pelo autor, o magistrado tem plena liberdade em lhe conferir o enquadramento jurídico mais adequado para a espécie.

290 ADI 2191 MC/AL, Relator: Ministro CELSO DE MELLO. Julgamento: 17/04/2000. Publicação D.J.: 26/04.00, p. 019, na qual cita farta doutrina neste sentido. 
jurídica invocadas como suporte da pretensão de inconstitucionalidade deduzida pelo autor da ação direta”. ${ }^{291}$

Tal entendimento aplica-se, igualmente, em relação ao preceito

fundamental invocado pelo requerente na arguição de descumprimento, como bem elucida TAVARES:

\begin{abstract}
"Nesse passo, importa sublinhar a particularidade de que o Supremo Tribunal Federal não fica jungido ao preceito específico invocado pelo autor, podendo considerar que é o caso de argüição de descumprimento por força de outro preceito fundamental, ou seja, a Corte é livre na apreciação dos fundamentos do pedido, aplicando-se as máximas jura novit curia e da mihi factum dabo tibi jus. Basta, na realidade, que o autor indique a ocorrência de descumprimento de preceito constitucional fundamental
\end{abstract}

291 "Como se sabe, em sede de controle normativo abstrato, não basta afirmar que determinada lei é inconstitucional. Impõe-se, ao autor da ação direta, fundamentar, juridicamente, a argüição de inconstitucionalidade, ainda que o Supremo Tribunal Federal - embora 'condicionado pelo pedido' (CLÈMERSON MERLIN CLÈVE, 'A Fiscalização Abstrata da Constitucionalidade no Direito Brasileiro', p. 154, $2^{\mathrm{a}}$ ed., 2000, RT) - não esteja vinculado à motivação exposta. É que, em tema de fiscalização abstrata de constitucionalidade, o elemento causal da ação direta (causa petendi) apresenta-se essencialmente aberto (ADI 561-DF, Rel. Min. CELSO DE MELLO - ADI 1.756-MA, Rel. Min. MOREIRA ALVES, v.g.). A imprescindibilidade da fundamentação do pedido de declaração de inconstitucionalidade formulado pelo autor da ação direta tem sido enfatizada pela jurisprudência do Supremo Tribunal Federal, que, com apoio em autorizado magistério doutrinário (JORGE MIRANDA, 'Manual de Direito Constitucional', tomo II/369, item n. 101, 2ª ed., 1988, Coimbra Editora, Limitada; ALEXANDRE DE MORAES, 'Direito Constitucional', p. 591, item n. 10.8, 7ª ed., 2000, Atlas; ZENO VELOSO, 'Controle Jurisdicional de Constitucionalidade’, p. 93/95, itens ns. 105, 107 e 108, 1999, CEJUP; GILMAR FERREIRA MENDES, 'Jurisdição Constitucional', p. 123, item n. 1.2, 2a ed., 1998, Saraiva, v.g.), assim se vem pronunciando sobre essa específica obrigação processual daquele que faz instaurar o processo de controle normativo abstrato: 'AÇÃO DIRETA DE INCONSTITUCIONALIDADE E DEVER PROCESSUAL DE FUNDAMENTAR A IMPUGNAÇÃO. - O Supremo Tribunal Federal não está condicionado, no desempenho de sua atividade jurisdicional, pelas razões de ordem jurídica invocadas como suporte da pretensão de inconstitucionalidade deduzida pelo autor da ação direta. Tal circunstância, no entanto, não suprime à parte o dever processual de motivar o pedido e de identificar, na Constituição, em obséquio ao princípio da especificação das normas, os dispositivos alegadamente violados pelo ato normativo que pretende impugnar. Impõe-se ao autor, no processo de controle concentrado de constitucionalidade, sob pena de nãoconhecimento da ação direta, indicar as normas de referência - que são aquelas inerentes ao ordenamento constitucional e que se revestem, por isso mesmo, de parametricidade - em ordem a viabilizar a aferição da conformidade vertical dos atos normativos infraconstitucionais.' (ADI 561-DF, Rel. Min. CELSO DE MELLO) 'Ação Direta de Inconstitucionalidade. Inépcia da inicial. É necessário, em ação direta de inconstitucionalidade, que venham expostos os fundamentos jurídicos do pedido com relação às normas impugnadas, não sendo de admitir-se alegação genérica de inconstitucionalidade sem qualquer demonstração razoável [...]. Ação direta de inconstitucionalidade de que não se conhece'. (RTJ 144/690, Rel. Min. MOREIRA ALVES - grifei) Tendo em vista as razões expostas, manifeste-se, sobre elas, o autor, no prazo de dez (10) dias, expondo, no que concerne aos arts. $2^{\circ}$ e $3^{\circ}$ da Lei $n^{\circ}$ 5.936/97, a fundamentação faltante.” In: ADI n 2191 MC/AL, Relator: Ministro CELSO DE MELLO. Julgamento: 17/04/2000. Publicação D.J.: 26/04.00, p. 019

Igualmente em sentido análogo, vejam-se os seguintes julgados: ADI ${ }^{0}$ 588/MT, Relator: Ministro CEZAR PELUSO. Julgamento: 14/04/2008. DJe-070, DIVULG.: 17/04/2008. PUBLIC: 18/04/2008; AC no 1383/DF. Relator: Ministra CÁRMEN LÚCIA. Julgamento: 10/11/2006. D.J.: 24/11/2006, pp.091; e ADI no 2394 MC/MG. Relator: Ministro CELSO DE MELLO. Julgamento: 29/06/2001. D.J.: 08/08/2001, p.04. 
existente e a todos dirigido, sendo irrelevante o correto ou adequado enquadramento.",292

Mas se mesmo no processo comum, segundo a teoria da substanciação, reconhecidamente adotada no Brasil, cabe ao juiz, a final, conferir a escorreita qualificação jurídica aos fatos narrados, qual seria, então, a utilidade de se utilizar no controle abstrato o princípio da causa de pedir aberta?

A resposta parece estar na natureza da própria causa de pedir no controle principal. Nessa espécie de processo, como visto, por se tratar de aferição de inconstitucionalidade em tese, não há, na maioria das vezes, necessidade da narrativa de fatos, que são, em regra, despiciendos para a análise em abstrato do conflito entre normas. Assim, não é aos fatos que o juiz constitucional confere qualificação jurídica. A tarefa que faz é, na verdade, de invocar estes ou aqueles princípios e regras constitucionais como parâmetro para a declaração de inconstitucionalidade.

Em meu sentir, a causa de pedir aberta permite que a Corte Constitucional invoque princípios e regras constitucionais não mencionados na petição inicial como parâmetro para a declaração de inconstitucionalidade, de modo a utilizá-los como suporte para desenvolver os fundamentos jurídicos da decisão. ${ }^{293}$

Deste modo, uma vez suscitada a inconstitucionalidade, a Corte pode se valer de todo o espectro normativo da Constituição para aferi-la ${ }^{294}$, o que leva à

\footnotetext{
${ }^{292}$ TAVARES, André Ramos. Tratado da argüição de preceito fundamental. São Paulo, Saraiva, 2001, p. 309.

${ }^{293}$ Conclusão semelhante é alcançada por JULIANO TAVEIRA BERNARDES, ao analisar o princípio da causa de pedir aberta em face do princípio do iura novit curia: "Sem embargo, ainda assim parece justificável a adoção do princípio processual da causa de pedir aberta. É que o juízo exercido nos processo objetivos de fiscalização da constitucionalidade considera normas jurídicas em tese, e não os eventuais fatos concretos a elas subsumíveis. Logo, a qualificação jurídica dessas normas não poderia ser suprida pelo princípio do iura novit cúria, porquanto a narração dos fatos que lhe corresponderiam não compõe a causa de pedir das ações de controle abstrato de constitucionalidade.” In: BERNARDES, Juliano Taveira. Controle abstrato de constitucionalidade: Elementos materiais e princípios processuais. São Paulo, Saraiva, 2004, p. 438.

294 "No processo objetivo, todavia, correlação só precisa existir entre a decisão e o pedido. O órgão controlador dispõe de poderes inquisitórios que lhe concedem ampla liberdade para exercer juízo de valor acerca da norma examinada com base na integralidade do parâmetro utilizável. Segundo o STF, o âmbito de congnoscibilidade da questão constitucional não se adstringe aos fundamentos constitucionais invocados pelo requerente, pois abarca todas as normas que compõem a Constituição Federal. Daí, a fundamentação dada pelo requerente pode ser
} 
conclusão que o precedente formado pelo julgamento de ação direta, ao menos implicitamente, haja considerado todo e qualquer fundamento para a eventual declaração de inconstitucionalidade ${ }^{295}$ ou de constitucionalidade.

Para aqueles que vislumbram as ações diretas como dúplices, haveria que se concluir que uma vez arguida a inconstitucionalidade na ação direta de inconstitucionalidade ou a constitucionalidade na ação declaratória de constitucionalidade, tanto a decisão que julga procedente como a que julga improcedente essas ações teria o condão de reconhecer a constitucionalidade ou a inconstitucionalidade sob todos os fundamentos jurídicos possíveis.

Deveras, as ações de caráter dúplice, como se sabe, são aquelas em que o demandado, na própria resposta (e sem a necessidade de reconvenção), deduz pedido contraposto ao do requerente. ${ }^{296}$ Nas ações de controle abstrato de constitucionalidade, esse pedido, ainda que não formulado expressamente pelos órgãos responsáveis pela edição da lei ou ato normativo impugnado ou, ainda, pelo Advogado Geral da União, estaria implícito, por força do previsto no art. 24 da Lei federal $n^{\circ} 9.868 / 99 .^{297}$

desconsiderada e suprida por outra encontrada pela Corte. Destarte, o julgamento das ações diretas não depende da 'causa petendi' formulada na inicial, ou seja, dos fundamentos jurídicos nela deduzidos, pois, havendo, nesse processo objetivo, argüição de inconstitucionalidade, a Corte deve considerá-la sob todos os aspectos em face da Constituição e não apenas diante daqueles focalizados pelo autor, presumindo-se, então, ao menos implicitamente, hajam sido considerados quaisquer fundamentos para eventual argüição de inconstitucionalidade.” In: Ibidem, p. 436.

295 “É da jurisprudência do Plenário, o entendimento de que, na ação direta de inconstitucionalidade, seu julgamento independe da causa petendi formulada na inicial, ou seja, dos fundamentos jurídicos nela deduzidos, pois, havendo, nesse processo objetivo, argüição de inconstitucionalidade, a Corte deve considerá-la sob todos os aspectos em face da Constituição e não apenas diante daqueles focalizados pelo autor. É de se presumir, então, que, no precedente, ao menos implicitamente, hajam sido considerados quaisquer fundamentos para eventual argüição de inconstitucionalidade, inclusive os apresentados na inicial da presente ação.” In: ADI 1.896-MC, Rel. Min. SYDNEY SANCHES, julgamento em 18-2-99, DJ de 28-5-99.

${ }^{296}$ Na lição de CÂNDIDO RANGEL DINAMARCO: “Ações dúplices são aqueles litígios ou procedimentos nos quais a lei permite ao réu deduzir, sem o formalismo de uma reconvenção, um pedido contraposto ao do autor; na própria contestação é deduzido um novo petitum, com o qual o demandado postula para si uma tutela jurisdicional fora dos limites do pedido constante na petição inicial.” In: DINAMARCO, Cândido Rangel. Vocabulário do processo civil. São Paulo, Malheiros, 2009, p. 56.

297 “Art. 24. Proclamada a constitucionalidade, julgar-se-á improcedente a ação direta ou procedente eventual ação declaratória; e, proclamada a inconstitucionalidade, julgar-se-á procedente a ação direta ou improcedente eventual ação declaratória”. 
TEORI ALBINO ZAVASCKI, posicionando-se no sentido da natureza dúplice das ações diretas de controle de constitucionalidade, aduz que:

“Tanto a ação direta de inconstitucionalidade quanto a ação declaratória de constitucionalidade têm natureza dúplice, ou seja, ambas têm aptidão para firmar, quando julgadas no mérito, juízo de constitucionalidade ou de inconstitucionalidade do preceito normativo que lhes dá objeto. Assim, a procedência da ação direta de inconstitucionalidade opera declaração de nulidade da norma inconstitucional, com a sua conseqüente eliminação do ordenamento jurídico. [...] Quando, todavia, for julgada improcedente, restará afirmada, para todos os efeitos, a constitucionalidade do preceito normativo." 298

Consigna, outrossim, que a duplicidade estaria expressamente prevista no artigo 173 do Regimento Interno do STF, bem como dos arts. 23 e 24 da Lei federal $n^{\circ} 9.868 / 99 .^{299}$

Opina, ainda, que o mesmo efeito ocorre nas ações declaratórias

de constitucionalidade:

"Fenômeno idêntico mas com sentido inverso ocorre no julgamento da ação declaratória de constitucionalidade: a sua procedência importa reconhecimento da constitucionalidade do preceito normativo; e a sua improcedência, a declaração da inconstitucionalidade, e, portanto, da sua nulidade, com a conseqüente exclusão, para todos os efeitos, do ordenamento positivo.”300

Esse entendimento não é pacífico na doutrina pátria, como demonstra a opinião de ELIVAL DA SILVA RAMOS, em sentido diametralmente contrário:

"Importa, por último, ressaltar que, na ação direta de inconstitucionalidade genérica, a decisão que desacolhe o pedido inicial não possui eficácia erga omnes, podendo ser proposta outra ação dessa natureza, com o mesmo objetivo, ou podendo ser a matéria discutida em argüição incidenter tantum." 301

\footnotetext{
${ }^{298}$ ZAVASCKI, Teori Albino. Eficácia das sentenças na jurisdição constitucional. São Paulo, Revista dos Tribunais, 2001, p. 46.

${ }^{299}$ Ibidem, p. 46.

${ }^{300}$ Ibidem, p. 47.

${ }^{301}$ RAMOS, Elival da Silva. A inconstitucionalidade das leis: Vício e sanção. São Paulo, Saraiva, 1994, p. 119.
} 
Afirma, ainda, que, com a finalidade de conferir eficácia erga omnes à declaração de constitucionalidade, a EC nº 3, de 1993 à Constituição de 1988 instituiu a ação declaratória de constitucionalidade de lei ou ato normativo federal, mas adverte que essa ação e a ação direta de inconstitucionalidade não se confundem, pois a primeira tem objeto mais restrito (lei ou ato normativo federal, enquanto a ação de inconstitucionalidade pode atingir também os estaduais) e legitimação para agir igualmente mais restrita (o que, após a Emenda Constitucional no 45 deixou de ser um fator distintivo, em virtude de esta Emenda, como se sabe, ter equiparado a legitimidade ativa para ambas as ações - cf. art. 103). Assevera, afinal, que "em ambos os casos, apenas a procedência do pedido, com a declaração de inconstitucionalidade ou constitucionalidade de lei ou ato normativo, gera efeitos erga omnes". ${ }^{302}$

Em meu entender, embora o efeito dúplice para as ações de controle de constitucionalidade pudesse ser considerado medida em princípio salutar, a evitar a repetição de ações e contribuindo para a celeridade processual, mostra-se difícil extrair esse efeito dos dispositivos da Lei federal $n^{\circ}$ 9.868/99, pois ali não está explicitamente indicado que a improcedência do pedido de inconstitucionalidade ou de constitucionalidade gerará o efeito oposto, isto é, a declaração de constitucionalidade ou inconstitucionalidade, respectivamente.

Ademais, o procedimento da ação declaratória de constitucionalidade é diverso daquele da ação direta de inconstitucionalidade, a dificultar a apresentação do pedido contraposto, como ocorre nas ações dúplices.

Portanto, não me parece correto, segundo a atual conformação legislativa, entender que as ações de controle abstrato de constitucionalidade possuam caráter dúplice.

${ }^{302}$ RAMOS, Elival da Silva. A inconstitucionalidade das leis: Vício e sanção. São Paulo, Saraiva, 1994, p. 120. 


\title{
3.2.6 O princípio da congruência
}

\begin{abstract}
É por meio do pedido que se fixa a extensão da tutela jurisdicional a ser prestada ${ }^{303}$, motivo pelo qual o princípio da ação ou demanda está umbilicalmente ligado ao princípio da congruência ou da correlação, que impede o órgão do Poder Judiciário de conceder tutela diversa da pleiteada, aquém ou além do que foi pedido.
\end{abstract}

O artigo 128 do Código de Processo Civil dispõe que o “juiz decidirá a lide nos limites em que foi proposta, sendo-lhe defeso conhecer de questões, não suscitadas, a cujo respeito a lei exige iniciativa da parte”.

Verifica-se que o dispositivo processual está intimamente ligado à noção de lide. Esta, como já demonstrado acima, é conceituada por CARNELUTTI como o conflito de interesses qualificado pela pretensão de um dos interessados e pela resistência do outro. $^{304}$

Ao analisar o conceito de lide, ressaltando seu sentido essencialmente sociológico, CELSO AGRÍCOLA BARBI esclarece que ela se apresenta no processo nos limites fixados pela parte:

"Isto é, mesmo que a lide, como entidade sociológica, fora do processo, tenha determinada extensão, ela pode ser apresentada apenas parcialmente no processo. E é nesses limites em que foi trazida ao juiz que este deve exercer a sua atividade.

Em outras palavras, o conflito de interesses que surgir entre duas pessoas será decidido pelo juiz não totalmente, mas apenas nos limites em que elas o levarem no processo. Usando a fórmula antiga, significa o artigo que o juiz não deve julgar além do pedido das partes: ne eat judex ultra petita partium." 305

\footnotetext{
${ }^{303}$ HUMBERTO THEODORO JÚNIOR, citando lição de ADOLFO SCHÖNKE, informa que o "pedido põe em marcha o processo e, por isso, é o ato mais importante do autor, além disso delimita o objeto litigioso (a lide) e, conseqüentemente, fixa os limites do ato judicial mais importante, que é a sentença.” In: THEODORO JÚNIOR, Humberto. Curso de Direito Processual Civil, v. I. 45ª ed., Rio de Janeiro, Forense, 2006, p. 404.

${ }^{304}$ Vide nota ${ }^{\circ}$ 4, supra.

${ }^{305}$ BARBI, Celso Agrícola. Comentários ao Código de Processo Civil, v. I. 10ª ed., Editora Forense, Rio de Janeiro, 1998, p. 392.
} 
CHIOVENDA, ao comentar os limites dos poderes do juiz, verificando que o primeiro deles refere-se "à correspondência necessária entre o requerido e o julgado [...] limite absoluto, determinável pelas regras de identificação das ações”306, esclarece, fazendo um paralelo com os elementos da demanda, que esses limites ensejariam as seguintes vedações: “(a) não poder o juiz pronunciar-se a favor ou contra pessoas que não são sujeitos da demanda; (b) não poder o juiz conceder ou negar coisa diversa da demandada; (c) não poder o juiz mudar a causa petendi”. ${ }^{307}$

É de se notar que o princípio da congruência, assim como o princípio da demanda, volta-se, precipuamente à preservação do contraditório e da ampla defesa e, em última instância, do devido processo legal. ${ }^{308}$

Transpondo tais conceitos ao processo objetivo de controle abstrato, no qual inexiste lide, pode-se entender que, para conferir aos órgãos dos quais emanaram os atos normativos apontados como inconstitucionais a possibilidade de conhecer e compreender os fundamentos jurídicos da inconstitucionalidade arguida, de modo que possam apresentar as razões da edição dos atos e a interpretação constitucional apta a dar suporte de validade às normas atacadas, é imprescindível que tenham uma clara noção acerca do pedido de inconstitucionalidade e de sua extensão.

Assim, via de regra, o princípio da congruência deve ser respeitado no controle abstrato de normas, a impedir que o tribunal declare a inconstitucionalidade de dispositivo acerca do qual não haja pedido na inicial.

Todavia, há exceções à sua incidência nesta esfera.

${ }^{306}$ CHIOVENDA, Giuseppe. Instituições de direito processual civil, v. 2. Tradução Paolo Capitanio, Campinas, Bookseller, 1998, p. 404.

${ }^{307}$ Ibidem, p. 405-406.

${ }^{308}$ Neste sentido, veja-se ARENHART, Sérgio Cruz. Reflexões sobre o princípio da demanda. In: FUX, Luiz; NERY JÚNIOR, Nelson; WAMBIER, Teresa Arruda Alvim (coord.). Processo e Constituição: Estudos em homenagem ao Professor José Carlos Barbosa Moreira. São Paulo, Revista dos Tribunais, 2006, p. 593 e THEODORO JÚNIOR, Humberto. Curso de Direito Processual Civil, v. I. $45^{\mathrm{a}}$ ed., Rio de Janeiro, Forense, 2006, p. 566. 
Há normas que se encontram indissociavelmente ligadas umas às outras por diversas espécies de vínculos. Imagine-se, $v$. g., o caso do decreto regulamentar que se volta à fiel execução da lei (CF, art. 84, IV, in fine): uma vez declarada a inconstitucionalidade da lei, nenhum sentido teria em manter a validade do decreto. Tendo em vista que este ato regulamentar retira seu fundamento de validade da lei declarada inconstitucional, com a retirada desta do ordenamento jurídico, aquele também deve ser extirpado, não podendo sobreviver sem a lei que lhe dá fundamento de validade.

Em outros casos, podem ocorrer vínculos de ligação entre dispositivos de uma mesma lei ou de diversas leis que formam um complexo normativo unitário.

\section{CARLOS BLANCO DE MORAIS ao tratar da} inconstitucionalidade consequente de normas não impugnadas esclarece que:

"A inconstitucionalidade consequente opera em cascata, através da propagação da relação de desvalor de uma norma principal, para as normas dela dependentes.

Essa dependência poderá ser hierárquico-formal (regulamento afectado pela inconstitucionalidade da lei que executa); hierárquico-material (decreto-lei complementar inquinado pela lei de bases que desenvolve); ou fundada em instrumentalidade necessária (disposições legais adjectivas atingidas pela inconstitucionalidade de outras que assumem em relação a elas, caráter principal).”309

CANOTILHO informa que a contradição entre o ato normativo e o parâmetro constitucional nem sempre é total, pois poderá "acontecer que só uma norma ou algumas normas constantes dos actos normativos estejam em desconformidade com as normas superiores da Constituição". ${ }^{310}$ Pondera, outrossim, que nesses casos, tal como ocorre na nulidade parcial dos negócios jurídicos, “a inconstitucionalidade de uma norma não conduz automaticamente à declaração de nulidade das restantes normas (incomunicação da

\footnotetext{
${ }^{309}$ MORAIS, Carlos Blanco de. Justiça Constitucional, t. I. $2^{\text {a }}$ ed., Coimbra, Coimbra Editora, 2006, p. 182.

${ }^{310}$ CANOTILHO, José Joaquim Gomes. Direito Constitucional. 6ª ed., Coimbra, Almedina, 1993, p. 1077.
} 
nulidade)”. ${ }^{311}$ Por fim, cita o mestre de Coimbra que há casos em que a nulidade parcial acarretará na nulidade total. Esse fenômeno ocorrerá quando:

"em consequência da declaração de inconstitucionalidade de uma norma, se reconheça que as normas restantes, conforme a Constituição, deixam de ter qualquer significado autônomo (critério da dependência). Além disso, haverá uma nulidade total quando o preceito inconstitucional fazia parte de uma regulamentação global à qual empresta sentido e justificação (critério da interdependência).”312

Com fundamento na jurisprudência do Supremo Tribunal Federal, GILMAR FERREIRA MENDES distingue duas espécies de vínculo entre os dispositivos de uma mesma lei, que acarretariam a inconstitucionalidade total da lei: a) relação de dependência, quando objetivamente, a parte isenta de vício não dispõe de autonomia própria; b) relação de interdependência, “quando se afigura impossível proceder-se a uma separação, seja porque as disposições legais formam uma unidade inseparável, seja porque a declaração parcial poderia caracterizar uma intervenção indevida na esfera de competência legislativa ou uma afronta à vontade do legislador”. 313

O Ministro CARLOS VELLOSO, em voto proferido na ADI 2895, asseverou que embora o STF, no controle abstrato, fique sujeito ao princípio do pedido:

"quando a declaração de inconstitucionalidade de uma norma afeta um sistema normativo dela dependente, ou, em virtude da declaração de inconstitucionalidade, normas subseqüentes são afetadas pela declaração, a declaração de inconstitucionalidade pode ser estendida a estas, porque ocorrente o fenômeno da inconstitucionalidade por 'arrastamento' ou 'atração'.,"314

Dessa forma, conjugando os critérios apresentados pela doutrina e jurisprudência, destacam-se as seguintes hipóteses de inconstitucionalidade consequencial ou

\footnotetext{
${ }^{311}$ CANOTILHO, José Joaquim Gomes. Direito Constitucional. 6a ed., Coimbra, Almedina, 1993, p. 1077.

${ }^{312}$ Ibidem, p. 1078.

${ }^{313}$ MENDES, Gilmar Ferreira. Controle de constitucionalidade: Aspectos jurídicos e políticos. São Paulo, Saraiva, 1990, p. 281.

${ }^{314}$ ADI 2875/AL. Relator: Ministro CARLOS VELLOSO. Julgamento: 02/02/2005, Tribunal Pleno. Publicação: D.J.: 20-05-2005, pp. 05, Ement. vol. 02192-03, pp. 0434. LEXSTF, v. 27, n. 319, 2005, p. 49-60, RTJ vol. 019402, pp. 0533.
} 
por arrastamento, decorrentes de: vínculo hierárquico, mácula na formação da norma, vínculo de dependência, vínculo de interdependência, a serem analisadas a seguir.

\subsubsection{Inconstitucionalidade consequencial por vínculo hierárquico}

Nesse caso, os decretos e demais atos regulamentares devem ser considerados inconstitucionais quando a lei que regulamentam for declarada inválida.

Há precedente do Supremo Tribunal Federal: na análise do pedido cautelar da ADI 173/DF, houve por bem o Ministro MOREIRA ALVES deferi-lo para o fim de suspender o dispositivo inquinado de inconstitucionalidade (art. $1^{\circ}$, da Lei $n^{0} 7.711$, de 22 de dezembro de 1998), assim como o decreto que o regulamentava, tendo entendido que a suspensão da eficácia do dispositivo da lei, “por via de conseqüência, suspenderá a eficácia do decreto regulamentador desse dispositivo legal”. 315316

\subsubsection{Inconstitucionalidade consequencial por mácula nos atos normativos que servem de seu pressuposto.}

Essa hipótese ocorre quando há um vício no processo de elaboração da norma de igual hierarquia. No Brasil, esta hipótese pode ocorrer em relação à resolução que delega poder legislativo ao Presidente da República (CF, art. 68, § 2º da medida provisória (CF, art. 62) em relação às leis geradas por meio destes dois processos legislativos.

\footnotetext{
${ }^{315}$ ADI 173 MC/DF, Relator: Ministro MOREIRA ALVES. Julgamento: 09/03/90, Tribunal Pleno. Publicação: D. J.: 27-04-1990, pp. 03422, Ement. vol.: 01578-01, pp. 011.

${ }^{316}$ ADI 3148, Relator Ministro CELSO DE MELLO. Julgamento: 13/12/2006, Tribunal Pleno. Publicação: DJe 112, divulg. 27-09-2007, public. 28-09-2007; DJ 28-09-2007, p. 026. Ement. vol. 02291-02, p. 0249. RTJ vol. 0202-03, p. 010148.
} 
Uma vez verificado o vício de inconstitucionalidade da resolução autorizadora, no caso da lei delegada ou da medida provisória originária, qual seria o seu efeito na lei final?

No caso das leis delegadas me parece que a delegação é uma parte do processo de formação da lei final. Havendo inconstitucionalidade no processo de aprovação da resolução que delega poderes ao Presidente da República, a lei daí resultante sofreria de vício por inconstitucionalidade formal.

Já no caso da medida provisória, se houver vício no processo de aprovação do projeto de lei de conversão, a lei daí originada também sofrerá de inconstitucionalidade formal.

Mesmo que não tenha sido impugnado o ato legislativo originário no pedido inicial, tudo leva a crer que, uma vez declarada a inconstitucionalidade do ato legislativo final (lei elaborada com base em delegação ou lei de conversão de medida provisória), o Tribunal tem liberdade para examinar a regularidade da emissão da resolução ou medida provisória dos quais se originou.

Nessa hipótese, embora a medida provisória e a resolução de delegação sejam atos autônomos, fazem parte do processo legislativo de criação das leis aprovadas como desdobramento delas, motivo pelo qual o Tribunal pode exercer sobre elas o controle, ainda que sem pedido expresso. ${ }^{317}$

\footnotetext{
317 Conclusão análoga é alcançada por BERNARDES: "É que a inconstitucionalidade do ato originário condiciona a própria validade do ciclo de formação da norma derivada. E essa 'relação de vinculação de caráter especial' entre atos normativos repercute de forma particularizada na validade do ato impugnado. Se o órgão controlador não pudesse fiscalizar a constitucionalidade do ato originário, não estaria exercendo, com toda a plenitude, controle sobre a eventual inconstitucionalidade formal do ato derivado. Disso decorre, então, competência institucional implícita para controlar também aquele tipo de ato. No entanto, aplica-se aqui o que se disse sobre os restritos efeitos de um reconhecimento da inconstitucionalidade incidental realizado de tal forma oficiosa.” In: BERNARDES, Juliano Taveira. Controle abstrato de constitucionalidade: Elementos materiais e princípios processuais. São Paulo, Saraiva, 2004, p. 428.
} 


\subsubsection{Inconstitucionalidade consequencial por vínculo de dependência}

Ocorre quando a parte restante da norma declarada inconstitucional, acerca da qual não há pedido expresso, não dispõe de autonomia própria. Aquilo que resta após o acolhimento do pedido de declaração de inconstitucionalidade não é suficiente para uma normatividade mínima, com nexo e coerência. ${ }^{318}$

\subsubsection{Inconstitucionalidade consequencial por vínculo de interdependência}

Neste caso, há uma interdependência tão forte entre os dispositivos, que se podem considerar uma unidade inseparável ou, ainda, que da declaração de inconstitucionalidade de apenas parte dos dispositivos restaria norma com sentido distinto daquele que o legislador quis conferir, de tal forma que a declaração de inconstitucionalidade de uns acarreta na extensão necessária desta a outros, ainda que não impugnados pelo requerente.

Na ADI 2728/AM, em que se discutia a constitucionalidade de lei estadual que tratava de ICMS, o Plenário do Supremo Tribunal Federal reconheceu a inconstitucionalidade formal do artigo $1^{\circ}$ da norma em virtude de ter sido veiculada em lei ordinária, enquanto exigia-se no caso lei complementar. Em virtude de tratar-se, portanto, de inconstitucionalidade formal, entendeu-se que embora uma das alíneas do artigo não tivesse

\footnotetext{
318 "A declaração de inconstitucionalidade dos artigos $2^{\circ}$ e $3^{\circ}$ da lei atacada implica seu esvaziamento. A declaração de inconstitucionalidade dos seus demais preceitos dá-se por arrastamento.” In: ADI 1144/RS. Relator: Min. EROS GRAU. Julgamento: 16/08/2006. Órgão Julgador: Tribunal Pleno. Publicação: DJ 08-092006, p. 033. Ement. Vol. 02246-01, p. 057. RTJ Vol. 00200-03, p. 01065. LEXSTF v. 28, n. 334, 2006, p. 2026.
} 
sido atacada no pedido inicial, deveria também ser declarada inconstitucional, por arrastamento. $^{319}$

Em outro caso, na ADI 2982-QO ${ }^{320}$, o Ministro GILMAR MENDES estendeu a declaração de inconstitucionalidade a dispositivos não mencionados na inicial. A ação direta de inconstitucionalidade foi proposta pelo Procurador-Geral de Justiça contra os arts. 22 e 28 da Lei estadual n ${ }^{\circ}$ 12.381/94, do Estado do Ceará (tratavam do repasse à Associação Cearense dos Magistrados e à Associação Cearense do Ministério Público de parcela da taxa judiciária). Em sua manifestação, o Advogado-Geral da União aduziu que o pedido inicial não abrangia todo o complexo normativo, que incluía, outrossim, o artigo $5^{\circ}$ e o parágrafo único do artigo 25 da referida lei, motivo pelo qual a ação não deveria ser conhecida. O Tribunal, todavia, entendeu, com apenas um voto em sentido contrário, que a inconstitucionalidade deveria ser estendida aos dispositivos não mencionados na inicial.

Em seu voto, o Ministro GILMAR MENDES sustentou que a preliminar suscitada pela AGU não procedia, primeiramente em virtude de os dispositivos efetivamente impugnados possuírem autonomia suficiente para uma declaração de inconstitucionalidade a eles restrita. Acrescentou que a manifestação do Procurador-Geral da República, em seu parecer, poderia ser entendida como aditamento à inicial (o que me parece impróprio) e, ainda que assim não fosse, que os dispositivos não impugnados poderiam ser objeto de inconstitucionalidade por arrastamento, pois:

\footnotetext{
${ }^{319}$ Do voto do Ministro MAURÍCIO CORRÊA extrai-se o seguinte trecho: "10. Sem embargo de tal contexto, porém, há na presente hipótese vício de forma insanável nos dispositivos impugnados e que precede essa análise de ilegalidade. É que o inciso I do artigo 161 da Carta da República exige, de forma expressa, que a definição do valor adicionado a que se refere o artigo 158, parágrafo único, inciso I - exatamente os $3 / 4$ da repartição que cabe aos Municípios -, seja realizada por lei complementar, daí por que é inadmissível que venha regulada em lei ordinária estadual. Inconstitucionais, nesses termos, as regras impugnadas que cuidam de estabelecer os critérios de apuração do valor adicionado, isto é, o inciso I e suas alíneas, assim como o parágrafo único e suas alíneas, ambos do artigo $1^{\circ}$ da Lei 2749/02. 11. Registro que a mácula atinge as alíneas 'b' e 'c' do inciso I do artigo $1^{\circ}$, dado que também definem parâmetros para a apuração do valor adicionado, tema como visto sujeito à reserva de lei complementar. Cuidando-se de vício formal, há que se aplicar a teoria da inconstitucionalidade conseqüencial, de modo que, mesmo não havendo pedido quanto a esses dispositivos, sua ilegitimidade é decorrência lógica do reconhecido defeito de forma de todo o inciso I. Seria inaceitável, data venia, que permanecessem soltos e sem sentido na lei estadual disposições sujeitas à lei complementar e, por isso, contrárias à Constituição Federal.” In: ADI 2738/AM. Relator: Ministro MARÍCIO CORRÊA. Julgamento: 28/05/2003, Tribunal Pleno. Publicação: D. J.: 20-02-2004, p. 016. Ement. Vol. 02140-02, pp. 0218. RTFP v. 15, n. 72, 2007, p. 317-329.

320 ADI-QO/CE 2982, Relator: Ministro GILMAR MENDES. Julgamento: 17/06/2004. Tribunal Pleno. Publicação: D. J. 12.11.2004, pp. 05. Ement. vol. 2172-01, pp. 0183, LEXSTF, v. 26, n. 312, 2005, pp. 105-115.
} 
"além de os dispositivos possuírem teor análogo e a causa de pedir ser exatamente a mesma, a declaração de inconstitucionalidade dos arts. 22 e 28 evidentemente acaba por atingir o disposto no art. $5^{\circ}$ e no parágrafo único do art. $25 ”,{ }^{321}$

Como se pode perceber, o referido julgado representa exceção à jurisprudência do STF, pois, no caso da interdependência recíproca de normas que formam um complexo normativo, não tem o Pretório Excelso admitido a extensão da declaração de inconstitucionalidade quando o pedido inicial não faz menção a todo o conjunto de normas. ${ }^{322}$ Essa matéria já foi amplamente abordada, v. os comentários feitos acima [item 3.2.3 (princípio da ação ou da demanda), subitem 3.2.3.5 (do pedido e suas especificações), supra].

\subsubsection{O princípio da subsidiariedade na ADPF (Lei federal $n^{\circ} 9.882 / 99$, art. $4^{\circ}, \S 1^{\circ}$ )}

O cabimento da arguição de descumprimento de preceito fundamental está condicionado à inexistência de outro meio eficaz de sanar a lesividade (Lei $n^{\circ} 9.882$, art. $\left.4^{\mathrm{o}}, \S 1^{\circ}\right){ }^{323}$

321 ADI-QO/CE 2982, Relator: Ministro GILMAR MENDES. Julgamento: 17/06/2004. Tribunal Pleno. Publicação: D. J. 12.11.2004, pp. 05. Ement. vol. 2172-01, pp. 0183, LEXSTF, v. 26, n. 312, 2005, pp. $105-115$. 322 “COMPLEXO NORMATIVO: 'O artigo 98 da Lei complementar n. 412 do Estado de Santa Catarina, não questionado, tem evidente correlação com o objeto da presente ação direta. A jurisprudência desta Corte é firme no tocante à imprescindibilidade de impugnação dos textos normativos que cuidem da mesma matéria atacada na ação direta. A demanda não pode atacar apenas um dos atos contidos no complexo normativo. O sistema de leis vinculadas a determinado tema deve ser questionado em sua íntegra. A razão disso reside no fato de a eficácia da declaração de inconstitucionalidade alcançar tão somente o ato impugnado e não o complexo no qual inserido. Nesse sentido: a ADI n. 2.174, Relator o Ministro Maurício Corrêa, DJ de 7-3-03; a ADI n. 1.187, Relator o Ministro Maurício Corrêa, DJ de 30-5-97; a ADI n. 2.133, Relator o Ministro Ilmar Galvão, DJ de 9-3-00; a ADI n. 2.451, Relator o Ministro Celso de Mello, $D J$ de $1^{\circ}-8-01$; a ADI n. 2.972, Relator o Ministro Carlos Britto, $D J$ de 29-10-03; e a ADI n. 2.992, Relator Ministro Eros Grau, DJ de 17-12-04. Não conheço desta ação direta [RISTF, artigo 21, § $\left.1^{\circ}\right]^{\prime} . ” ' I n:$ ADI 4.043, Rel. Min. Eros Grau, decisão monocrática, julgamento em 3-3-09, DJE de 11-3-09.

323 “Art. $4^{\circ}$ omissis.

$\S 1^{\circ}$ Não será admitida a argüição de descumprimento de preceito fundamental quando houver outro meio eficaz para sanar a lesividade.” 
A inspiração para esta norma possivelmente advém do princípio da subsidiariedade existente no direito alemão e no direito espanhol, como requisito para o cabimento para o recurso constitucional e o recurso de amparo, respectivamente.

Todavia, cabe questionar se o cabimento arguição de descumprimento de preceito fundamental está condicionado ao exaurimento de todos os meios de impugnação existentes no ordenamento jurídico, ou apenas daqueles que trariam ao interessado o mesmo efeito da tutela que seria proferida na arguição de descumprimento de preceito fundamental ou, ainda, somente daqueles referentes ao processo objetivo de controle de constitucionalidade.

Em defesa da posição no sentido de ser necessário o esgotamento de todos os recursos judiciais cabíveis, incluídos aí aqueles de índole subjetiva, KILDARE GONÇALVES CARVALHO propõe que:

“Ainda segundo o $\S 1^{\circ}$ do artigo $4^{\circ}$ da Lei n. 9.882/99, a argüição não será admitida quando houver outro meio eficaz de sanar a lesividade. Verifica-se, portanto, que a argüição constitui instrumento excepcional e extremo, supletivo e subsidiário, só podendo ser utilizado quando inexistir outro meio eficaz para sanar a lesividade, como argüição de inconstitucionalidade, os recursos previstos na legislação processual, inclusive o extraordinário.”324

Para ALEXANDRE DE MORAES, na análise da subsidiariedade, a lei teria conferido ao Supremo Tribunal Federal um certo grau de discricionariedade para conhecimento ou não da arguição de descumprimento de preceito fundamental. ${ }^{325}$

${ }^{324}$ CARVALHO, Kildare Gonçalves. Direito Constitucional. Belo Horizonte, Del Rey, 2006, p. 382.

325 “Note-se que, em face do art. $4^{\circ}$, caput, e $\S 1^{\circ}$, da Lei no $9.882 / 99$, que autoriza a não-admissão da arguição de descumprimento de preceito fundamental, quando não for ocaso ou quando houver outro meio eficaz de sanar a lesividade, foi concedida certa discricionariedade ao STF, na escolha das argüições que deverão ser processadas e julgadas, podendo, em face se seu caráter subsidiário, deixar de conhecê-las quando concluir pela inexistência de relevante interesse público, sob pena de tornar-se uma nova instância recursal para todos os julgados dos tribunais superiores e inferiores.

Dessa forma, entende-se que o STF poderá exercer um juízo de admissibilidade discricionário para a utilização desse importantíssimo instrumento de efetividade dos princípios e direitos fundamentais, levando em conta o interesse público e a ausência de outros mecanismos jurisdicionais efetivos.” In: MORAES, Alexandre de. Jurisdição constitucional e tribunais constitucionais. $2^{a}$ ed., São Paulo, Atlas, 2003, p. 266. 
A discricionariedade - com todo o grau de subjetividade que o termo revela - utilizada para limitar o acesso a instrumento crucial de defesa dos preceitos fundamentais, normas da mais altaneira importância no seio da Constituição, não se revela como critério de natureza objetiva, indispensável à aferição de cabimento da ADPF.

Por outro lado, parte significativa da doutrina entende não ser necessário o esgotamento de todos os meios para sanar a lesão ao preceito fundamental, mas apenas que não haja meio eficaz de preservá-la, havendo neste contexto quem afirme que o meio eficaz se restringe aos instrumentos do controle objetivo de constitucionalidade.

Fazendo uma interpretação conjunta da aplicabilidade das modalidades principal e incidental de arguição de descumprimento de preceito fundamental, previstas, respectivamente no caput do artigo $1^{\circ}$ e no $\S 3^{\circ}$, do artigo $5^{\circ}$ e no artigo 10 , caput, da Lei federal $n^{\circ}$ 9.882/99, ANDRÉ RAMOS TAVARES procura demonstrar que ambas se voltam a conferir ao instituto uma aplicabilidade mais estendida, alcançando inclusive o “controle de atos particulares, quando relevante sua apreciação para os interesses da nação”. ${ }^{326}$

WALTER CLAUDIUS ROTHENBURG, em posição que se afasta do entendimento da doutrina majoritária sobre o tema, defende que a afronta a preceito fundamental, em virtude de sua maior relevância e importância, levaria ao afastamento do princípio da subsidiariedade no caso de cabimento de outras ações de caráter abstrato, havendo preferência para a ADPF. ${ }^{327}$

\footnotetext{
${ }^{326}$ TAVARES, André Ramos. Tratado da argüição de descumprimento de preceito fundamental. São Paulo, Saraiva, 2001, p. 243. Esclarece, ainda, o autor: "Como o $\S 1^{\circ}$ do art. $4^{\circ}$ deve ser compreendido dentro da sistemática da Lei, o certo será, partindo das hipóteses já traçadas pelo art. $1^{\circ}$, absorver outras hipóteses por via da incidência da regra de abertura do $\S 4^{\circ}$ do art. $1^{\circ}$. Não se deve considerar, pois, o referido parágrafo como uma exceção à regra do art. $1^{\circ}$. Se assim fosse o $\S 1^{\circ}$ do art. $4^{\circ}$ deveria estar inserido no próprio art. $1^{\circ}$. De concluir, pois, que o dispositivo controvertido traz uma regra de abertura e não de limitação. Assim, reconhecendo a autonomia da argüição, por força do art. $1^{\circ}$ da Lei e, acima de tudo, por força das normas constitucionais aplicáveis à hipótese, infere-se que o art. $4^{\circ}$ ainda possibilita o cabimento da argüição em hipóteses diversas, quando não houver outro meio eficaz para sanar a lesividade.” In: Ibidem, p. 244.

327 "A argüição em sua modalidade direta praticamente afasta o problema da subsidiariedade. Pode nem ser cabível a ação direta de inconstitucionalidade (quanto o objeto for ato normativo municipal anterior à Constituição ou infralegal, ou ato concreto do Poder Público), em razão da jurisprudência restritiva do Supremo Tribunal Federal. Quando o objeto também for passível de ação direta de inconstitucionalidade, em vez de
} 
Não creio que o caráter fundamental da norma tenha o condão de impor o uso da ADPF. Fator relevante é que haja no ordenamento jurídico um instrumento hábil a sanar a lesividade no caso concreto. Essencialmente, não há diferença entre o uso da ação direta de inconstitucionalidade, ou da ação declaratória de constitucionalidade, e da arguição de descumprimento de preceito fundamental. Portanto, entendo deva ser prestigiada a regra legal, a impor o uso apenas subsidiário da ADPF, não advindo daí nenhum prejuízo para a proteção do preceito fundamental, que poderá ser resguardado de maneira tão eficaz quanto por meio de ação direta de inconstitucionalidade ou declaratória de constitucionalidade.

Portanto, quando houver outro instrumento de controle objetivo de constitucionalidade hábil a sanar a lesividade, parece não haver dúvida quanto ao não cabimento da arguição de descumprimento de preceito fundamental. Assim, havendo a possibilidade de ajuizamento de ação direta de inconstitucionalidade, por ação ou omissão, ou ação declaratória de constitucionalidade, não é possível o manejo da ADPF. ${ }^{328}$

Esse é também o entendimento do Supremo Tribunal Federal. Em ação ajuizada contra provimento de Tribunal de Justiça estadual que ostentava os requisitos para ser submetido ao controle abstrato de normas, a Ministra ELLEN GRACIE, em decisão monocrática, entendeu que se tratava de ato que, "no controle abstrato de normas,

subsidiariedade, haverá preferência para a argüição, em função da maior importância da norma constitucional violada (preceito fundamental) e da relevância que venha a ser reconhecida no caso à questão constitucional. No cotejo entre a fundamentalidade do parâmetro e a relevância do fundamento da controvérsia constitucional, por um lado, e a subsidiariedade, por outro, aquelas há de prevalecer.” ROTHENBURG, Walter Claudius. Argüição de descumprimento de preceito fundamental. In: TAVARES, André Ramos; ROTHERNBURG, Walter Claudius (orgs.). Argüição de descumprimento de preceito fundamental à luz da Lei $\mathbf{n}^{\circ}$ 9.882/99. São Paulo, Atlas, 2001, p. 225.

${ }^{328}$ Nesse sentido, a posição de DANIEL SARMENTO: "Não há dúvida de que o princípio em questão exclui a possibilidade da argüição, sempre que outro instrumento de fiscalização abstrata de constitucionalidade for suficiente para sanar a lesão ou ameaça ao preceito fundamental. Assim, por exemplo, não cabe ADPF para a retirada do mundo jurídico de lei ou ato normativo estadual, posterior à Constituição, pois para isso já existe a Adin. Do mesmo modo, a ADPF será inadmissível para a declaração de constitucionalidade de lei ou ato normativo federal superveniente à ordem constitucional, pois para tal finalidade é possível o uso da Adcon." SARMENTO, Daniel. Apontamentos sobre a argüição de descumprimento de preceito fundamental. In: TAVARES, André Ramos; ROTHERNBURG, Walter Claudius (orgs.). Argüição de descumprimento de preceito fundamental à luz da Lei no 9.882/99. São Paulo, Atlas, 2001, p. 103. 
deveria, em tese, ser objeto de eventual ação direta de inconstitucionalidade״ ${ }^{329}$, motivo pelo qual, "havendo, como se mostrou, outro instrumento de controle abstrato de normas apto a sanar, em tese e de maneira eficaz, a alegada situação de lesividade” ${ }^{330}$ não conheceu o pedido formulado, com fundamento no artigo $4^{\circ}, \S 1^{\circ}$, da Lei ${ }^{\circ}$ 9.882/99, combinado com o artigo 21, $\S 1^{\circ}$, do Regimento Interno do Tribunal.

No mesmo sentido, a decisão monocrática proferida pelo Ministro CELSO DE MELLO, relativa à possibilidade de instauração, no âmbito do Estadomembro, de processo objetivo de controle de constitucionalidade afastaria a possibilidade de emprego da ADPF:

\begin{abstract}
“A possibilidade de instauração, no âmbito do Estado-membro, de processo objetivo de fiscalização normativa abstrata de leis municipais contestadas em face da Constituição Estadual (CF, art. 125, § $2^{\circ}$ ) torna inadmissível, por efeito da incidência do princípio da subsidiariedade (Lei $n^{\circ}$ 9.882/99, art. $4^{\circ}$, $\S 1^{\circ}$ ), o acesso imediato à argüição de descumprimento de preceito fundamental. É que, nesse processo de controle abstrato de normas locais, permite-se, ao Tribunal de Justiça estadual, a concessão, até mesmo "in limine”, de provimento cautelar neutralizador da suposta lesividade do diploma legislativo impugnado, a evidenciar a existência, no plano local, de instrumento processual de caráter objetivo apto a sanar, de modo pronto e eficaz, a situação de lesividade, atual ou potencial, alegadamente provocada por leis ou atos normativos editados pelo Município.”331 332
\end{abstract}

Resta, então, saber se a existência de meios de impugnação relativos aos processos de índole subjetiva seriam igualmente capazes de afastar a utilização da ADPF.

\footnotetext{
${ }^{329}$ ADPF 87, D.J. n ${ }^{\circ} .188$, do dia 06/10/2008.

${ }^{330}$ ADPF 87, D.J. $n^{\circ}$. 188, do dia 06/10/2008.

${ }^{331}$ ADPF 100, Relator Ministro CELSO DE MELLO, D.J. no 240, do dia 18/12/2008.

${ }^{332}$ Veja-se, ainda nesta toada, a seguinte decisão monocrática: "No caso dos autos, a impugnação suscitada pela Mesa da Assembléia Legislativa de São Paulo poderia ser manifestada por meio de ação direta de inconstitucionalidade, meio eficaz bastante para sanar eventual lesividade do provimento sob enfoque. Registrese, por outro lado, que o mencionado Provimento ${ }^{\circ}$ 747/2000 é objeto da ADI 2.415, de que sou Relator, formalizada pela Associação dos Notários e Registradores do Brasil - ANOREG. Evidente, desse modo, a ausência do requisito previsto no referido art. $4^{\circ}, \S 1^{\circ}$, da Lei $n^{\circ}$ 9.882/99, uma vez que os efeitos lesivos do ato impugnado podem ser sanados por meio eficaz que não a argüição de descumprimento de preceito fundamental. Ante o exposto, indefiro liminarmente a inicial, na forma do artigo $4^{\circ}$, caput, da Lei $\mathrm{n}^{\circ}$ 9.882/99, determinando o arquivamento do feito.” In: ADPF nº 13, Relator Ministro ILMAR GALVÃO, D.J. nº 67, do dia 05/04/2001.
} 
Em decisão monocrática proferida na ADPF 17, firmou o

Ministro CELSO DE MELLO o seguinte entendimento:

\begin{abstract}
"Vê-se, pois, que a argüição de descumprimento de preceito fundamental somente poderá ser utilizada, se se demonstrar que, por parte do interessado, houve o prévio exaurimento de outros mecanismos processuais, previstos em nosso ordenamento positivo, capazes de fazer cessar a situação de lesividade ou de potencialidade danosa resultante dos atos estatais questionados. Foi por essa razão que o Supremo Tribunal Federal, tendo em consideração o princípio da subsidiariedade, não conheceu, quer em sede plenária (ADPF 3-CE, Rel. Min. SYDNEY SANCHES), quer, ainda, em decisões monocráticas (ADPF 12-DF, Rel. Min. ILMAR GALVÃO - ADPF 13-SP, Rel. Min. ILMAR GALVÃO), de argüições de descumprimento de preceito fundamental, precisamente por entender que existiam, no contexto delineado naquelas ações, outros meios processuais - tais como o mandado de segurança, a ação direta de inconstitucionalidade (por violação positiva da Carta Política), o agravo regimental e o recurso extraordinário (que admitem, excepcionalmente, a possibilidade de outorga cautelar de efeito suspensivo) e a reclamacão-, todos eles aptos a neutralizar a suposta lesividade dos atos impugnados. Como precedentemente enfatizado, o princípio da subsidiariedade - que rege a instauração do processo de argüição de descumprimento de preceito fundamental - acha-se consagrado no art. $4^{\circ}, \S 1^{\circ}$, da Lei $n^{\circ} 9.882 / 99$, que condiciona, o ajuizamento dessa especial ação de índole constitucional, à ausência de qualquer outro meio processual apto a sanar, de modó eficaz, a situação de lesividade indicada pelo autor." ${ }^{333}$
\end{abstract}

Em outro caso concreto, entendeu o tribunal que, sendo a ADPF “ação de natureza constitucional cuja admissão é vinculada à inexistência de qualquer outro

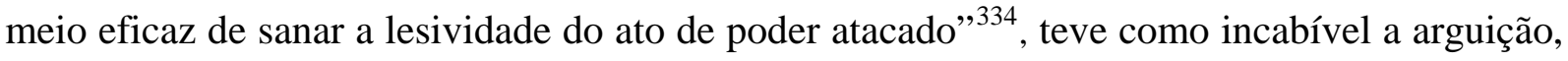
em virtude da possibilidade de haver "a reforma de decisão do Presidente do Superior Tribunal de Justiça, decisão esta passível de reexame por meio de agravo regimental, que, inclusive, [...] se encontra(va) aguardando [...] julgamento”. 335

Todavia, o próprio Ministro CELSO DE MELLO, na decisão acima mencionada ressaltou que a mera possibilidade de utilização de outros meios processuais não seria suficiente para a invocação do princípio da subsidiariedade, pois, para a

\footnotetext{
${ }^{333}$ ADPF $n^{\circ}$ 17, Relator Ministro CELSO DE MELLO, D.J. n 176 , do dia 28/09/2001.

${ }^{334} \mathrm{ADPF} \mathrm{n}^{\circ} 12$, Relator Ministro ILMAR GALVÃO, D.J. n 59 do dia 26/03/2001.

${ }^{335}$ Ibidem.
} 
sua incidência, é necessário que os mecanismos processuais existentes "mostrem-se aptos a sanar, de modo eficaz, a situação de lesividade” ${ }^{336}$, sob pena de:

“a indevida aplicação do princípio da subsidiariedade [...] afetar a utilização dessa relevantíssima ação de índole constitucional, o que representaria, em última análise, a inaceitável frustração do sistema de proteção, instituído na Carta Política, de valores essenciais, de preceitos fundamentais e de direitos básicos, com grave comprometimento da própria efetividade da Constituição".337

O aperfeiçoamento da jurisprudência demonstrou, assim, que o princípio da subsidiariedade deveria ser visto com acentuada cautela, não podendo:

“ser invocado para impedir o exercício constitucional da argüição de descumprimento de preceito fundamental, eis que esse instrumento está vocacionado a viabilizar, numa dimensão estritamente objetiva, a realização jurisdicional de direitos básicos, de valores essenciais e de preceitos fundamentais contemplados no texto da Constituição da República”."338

GILMAR FERREIRA MENDES, após discorrer acerca da hipótese mais restritiva de cabimento da ADPF, na qual a ação só poderia ser proposta se já se tivesse verificado a exaustão de todos os meios eficazes de afastar a lesão no âmbito judicial, pondera que:

“Uma leitura mais cuidadosa há de revelar, porém, que, na análise sobre a eficácia da proteção de preceito fundamental nesse processo, deve predominar um enfoque objetivo ou de proteção da ordem constitucional objetiva. Em outros termos, o princípio da subsidiariedade - inexistência de outro meio eficaz de sanar a lesão - contido no art. $4^{\circ}$, § $1^{\circ}$, da Lei n. 9.882, de 1999, há de ser compreendido no contexto da ordem constitucional global.

Nesse sentido, se se considera o caráter enfaticamente objetivo do instituto (o que resulta inclusive da legitimação ativa), meio eficaz de sanar a lesão parece ser aquele apto a resolver a controvérsia constitucional relevante de forma ampla, geral e imediata.”339

\footnotetext{
${ }^{336}$ ADPF n $^{\circ} 17$, Relator Ministro CELSO DE MELLO, D.J. n ${ }^{\circ}$ 176, do dia 28/09/2001.

${ }^{337}$ ADPF no $^{\circ} 17$, Relator Ministro CELSO DE MELLO, D.J. no 176, do dia 28/09/2001.

${ }^{338}$ ADPF n ${ }^{\circ}$ 126-MC, Relator Ministro CELSO DE MELLO, decisão monocrática, julgamento em 19-12-07, D.J.E. DE $1^{\circ}-02-08$.

${ }^{339}$ MENDES, Gilmar Ferreira. Argüição de descumprimento de preceito fundamental. Comentários à Lei n. 9.882, de 3-12-1999. São Paulo, Saraiva, 2007, p. 111.
} 
Coerente à sua posição, na ADPF 76, o Ministro GILMAR MENDES proferiu decisão monocrática acentuando que a existência de processos ordinários ou recursos extraordinários não deve excluir, desde logo, a utilização da ADPF, pois, "tendo em vista o caráter acentuadamente objetivo da argüição de descumprimento, o juízo de subsidiariedade há de ter em vista, especialmente, os demais processos objetivos já consolidados no sistema constitucional”. 340

Todavia, apesar de frisar que, em decorrência do perfil objetivo da arguição de descumprimento, dificilmente poder-se-ia vislumbrar uma autêntica relação de subsidiariedade entre a ADPF e as formas normais ou convencionais de controle de constitucionalidade do sistema difuso, entende GILMAR MENDES que a ação está sujeita ao juízo de relevância, que seria um requisito implícito de admissibilidade do pedido. No referido caso concreto (ADPF 76), o Ministro GILMAR MENDES invocou o princípio da relevância para negar seguimento à ação, argumentando que havia, ao menos em tese, outras medidas processuais cabíveis e efetivas para questionar os atos alvejados, motivo pelo qual concluiu que o conhecimento da $\mathrm{ADPF}$ no caso não seria compatível com o princípio da subsidiariedade. ${ }^{341}$

\footnotetext{
${ }^{340}$ ADPF n $^{\circ}$ 76, Relator Ministro GILMAR MENDES, D.J. $n^{\circ}$ 36, do dia 20/02/2006 (grifo nosso), da qual se extrai o seguinte trecho: "Destarte, assumida a plausibilidade da alegada violação ao preceito constitucional, cabível a ação direta de inconstitucionalidade ou de constitucionalidade, não será admissível a argüição de descumprimento. Em sentido contrário, em princípio, não sendo admitida a utilização de ações diretas de constitucionalidade ou de inconstitucionalidade - isto é, não se verificando a existência de meio apto para solver a controvérsia constitucional relevante de forma ampla, geral e imediata -, há de se entender possível a utilização da argüição de descumprimento de preceito fundamental. É o que ocorre, fundamentalmente, nos casos relativos ao controle de legitimidade do direito pré-constitucional, do direito municipal em face da Constituição Federal e nas controvérsias sobre direito pós-constitucional já revogado ou cujos efeitos já se exauriram. Nesses casos, em face do não-cabimento da ação direta de inconstitucionalidade, não há como deixar de reconhecer, em princípio, a admissibilidade da argüição de descumprimento. Não se pode admitir que a existência de processos ordinários e recursos extraordinários deva excluir, a priori, a utilização da argüição de descumprimento de preceito fundamental. Até porque o instituto assume, entre nós, feição marcadamente objetiva. Nessas hipóteses, ante a inexistência de processo de índole objetiva, apto a solver, de uma vez por todas, a controvérsia constitucional, afigurar-se-ia integralmente aplicável a argüição de descumprimento de preceito fundamental. É que as ações originárias e o próprio recurso extraordinário não parecem, as mais das vezes, capazes de resolver a controvérsia constitucional de forma geral, definitiva e imediata. A necessidade de interposição de um sem número de recursos extraordinários idênticos poderá, em verdade, constituir-se em ameaça ao livre funcionamento do STF e das próprias Cortes ordinárias.”

${ }^{341}$ ADPF n ${ }^{\circ}$ 76, Relator Ministro GILMAR MENDES, D.J. no 36, do dia 20/02/2006: "Isso não significa, porém, que se possa perder a dimensão de que a ADPF é destinada, basicamente, a resguardar a integridade da ordem jurídico-constitucional. Destarte, não tendo havido qualquer impugnação dos atos singulares ordinários, que,
} 
Percebe-se que a jurisprudência do STF parece não estar ainda solidamente firmada sobre o tema.

O Supremo Tribunal Federal tem entendido que na hipótese de existência de múltiplas ações, nos diversos graus de jurisdição, nas quais há decisões e interpretações divergentes sobre a matéria discutida, a gerar situação de insegurança jurídica, diante da inexistência de outro meio hábil para solucionar a polêmica existente, reputa-se atendido o princípio da subsidiariedade. ${ }^{342}$

Por outro lado, embora a arguição de descumprimento de preceito fundamental não seja um instrumento voltado a saltar instâncias, ou graus de jurisdição $^{343}$, o caráter subsidiário deve ser visto com alguma cautela, sob pena de inviabilizar o uso do instituto, ao menos em sua forma incidental. WALTER CLAUDIUS ROTHENBURG suscita a questão de ser o fator tempo igualmente significativo, podendo recomendar a antecipação de decisões acerca de controvérsias constitucionais relevantes “num

reitere-se, in casu, seria apta para solver a controvérsia de forma plena, não há como justificar, na espécie, a utilização da ADPF em face do disposto no art. $4^{\circ}$, § $1^{\circ}$, da Lei n ${ }^{\circ}$ 9.882/99. Parece evidente que referido instituto, cuja nobreza é dispensável destacar, não pode ser utilizado para suprir inércia ou omissão de eventual interessado. Como o instituto da ADPF assume feição eminentemente objetiva, o juízo de relevância deve ser interpretado como requisito implícito de admissibilidade do pedido. Seria possível admitir, em tese, a propositura de ADPF diretamente contra ato do Poder Público, nas hipóteses em que, em razão da relevância da matéria, a adoção da via ordinária acarrete danos de difícil reparação à ordem jurídica. O caso em apreço, contudo, revela que as medidas ordinárias à disposição da ora requerente - e, não utilizadas - poderiam ter plena eficácia. Ressalte-se que a fórmula da relevância do interesse público, para justificar a admissão da argüição de descumprimento (explícita no modelo alemão), está implícita no sistema criado pelo legislador brasileiro. No presente caso, afigura-se de solar evidência a falta de relevância jurídica para a instauração da ADPF. Assim, tendo em vista a existência, pelo menos em tese, de outras medidas processuais cabíveis e efetivas para questionar os atos em apreço, entendo que o conhecimento do presente pedido de ADPF não é compatível com uma interpretação adequada do princípio da subsidiariedade. Nestes termos, indefiro, liminarmente, a petição inicial (Lei no 9.868/1999, art. $4^{\circ}$ ).”

${ }^{342}$ ADPF n ${ }^{\circ}$ 101, Relatora Ministra CÁRMEN LÚCIA, julgamento em 11-03-09, Plenário, Informativo Supremo Tribunal Federal $n^{\circ} 538$.

343 "Não se pode, com efeito, ampliar o alcance da ADPF, sob pena de transformá-la em verdadeiro sucedâneo ou substitutivo de recurso próprio, ajuizado diretamente perante o órgão máximo do Poder Judiciário.” In: ADPF no 155-MC, Relator Ministro RICARDO LEWANDOWSKI, decisão monocrática, julgamento em 4-12-08, DJE de 11-12-08. 
cenário de decisões pontuais divergentes e de insuportável demora do trâmite processual até decisões definitivas (não necessariamente homogêneas)”. 344

A própria ausência de definição da controvérsia, diante da multiplicidade de decisões contraditórias proferidas em instâncias inferiores, pode caracterizar a lesão a preceito fundamental em virtude de ameaça ao princípio da segurança jurídica, como bem entendeu o Ministro GILMAR MENDES. ${ }^{345}$

A nova feição conferida pelo Supremo Tribunal Federal ao mandado de injunção ${ }^{346}$, com o reconhecimento de que a decisão possui efeitos erga omnes, parece levar à conclusão de que o cabimento desta espécie também deva ser levado em conta para o fim de constatar a subsidiariedade, pois os efeitos que se pode alcançar com ele são tão ou mais eficazes que aqueles que se alcança com os instrumentos objetivos de controle de constitucionalidade.

Pode-se concluir, assim, que, sob o ponto de vista processual, a exigência do uso subsidiário da ADPF revela-se como um específico pressuposto processual negativo ao uso desta espécie de ação. De fato, havendo outros meios processuais, que, na minha compreensão podem ser de caráter objetivo ou mesmo subjetivo, desde que hábeis a sanar a lesão de maneira completa e eficaz, tal qual se a própria ADPF estivesse sendo utilizada, será incabível o manejo desta ação constitucional.

\footnotetext{
344 ROTHENBURG, Walter Claudius. Argüição de descumprimento de preceito fundamental. In: ROTHENBURG, Walter Claudius; TAVARES André Ramos; (orgs.). Argüição de descumprimento de preceito fundamental à luz da Lei $\mathbf{n}^{\mathbf{0}}$ 9.882/99. São Paulo, Atlas, 2001, p. 255.

345 “Ademais, a ausência de definição da controvérsia ou a própria decisão prolatada pelas instâncias judiciais poderá ser a concretização da lesão a preceito fundamental. Em um sistema dotado de órgão de cúpula, que tem a missão de guarda da Constituição, a multiplicidade ou a diversidade de soluções pode constituir-se, por si só, em uma ameaça ao princípio constitucional da segurança jurídica e, por conseguinte, em uma autêntica lesão a preceito fundamental.” In: ADPF n ${ }^{\circ}$ 76, Relator Ministro GILMAR MENDES, D.J. no 36, do dia 20/02/2006.

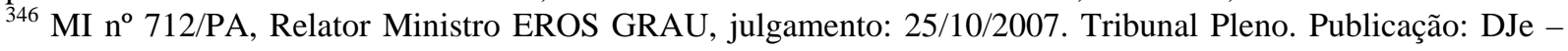
206, divulg. 30-10-2008, public. 31-10-2008. Ement. vol. 02339-03, p. 384.
} 


\subsubsection{O princípio da livre investigação das provas e o princípio inquisitivo [Lei federal $\mathbf{n}^{0}$ 9.868/99, art. $9^{\circ}, \S \S 1^{\circ}$ a $3^{\circ}(\mathrm{ADI})$; art. $20, \S \S 1^{\circ}$ a $3^{\circ}$ (ADC); e Lei federal $\mathrm{n}^{\circ}$ 9.882/99, art. $\left.6^{0}, \S 1^{\circ}\right]$}

Levando-se em conta a maior ou menor atuação do magistrado na condução do processo, evidenciam-se as espécies de processo inquisitivo (ou inquisitório) e dispositivo, respectivamente.

O princípio dispositivo costuma ser visto, comumente, como a "regra de que o juiz depende, na instrução da causa, da iniciativa das partes quanto às provas e às alegações em que se fundamentará a decisão: iudex secundum allegata partium iudicare debet”. 347

É um princípio de forte inspiração liberal, concebido para salvaguardar a imparcialidade do juiz.

No âmbito do processo penal, costuma-se distinguir o processo inquisitivo do acusatório. No primeiro, “funções de acusar, defender e julgar encontram-se enfeixadas em um único órgão, é o juiz que inicia de ofício o processo, que recolhe as provas e que, a final, profere a decisão”. 348 Já no processo acusatório, há “um processo penal de partes, em que acusador e acusado se encontram em pé de igualdade; é, ainda, um processo de ação, com as garantias da imparcialidade do juiz, do contraditório e da publicidade”. ${ }^{349}$

A moderna doutrina processual civil, todavia, partindo do pressuposto de que o processo é público, tem mitigado a aplicação do princípio dispositivo e

347 ARAÚJO CINTRA, Antonio Carlos de; GRINOVER, Ada Pellegrini; DINAMARCO, Cândido Rangel. Teoria geral do processo. $25^{\mathrm{a}}$ ed., São Paulo, Malheiros, 2009, p. 70.

${ }^{348}$ Ibidem, p.64.

${ }^{349}$ Ibidem, p. 64. 
enfatizado a necessidade de participação do juiz na produção da prova. ${ }^{350}$ Sustenta BEDAQUE, ao comentar os escopos do processo, a superação da visão privatista do processo:

"Superada hoje a corrente que considera como objeto do processo a defesa de direitos subjetivos, pois resulta de uma análise privatista do fenômeno. Sua finalidade é a atuação do direito, sendo a proteção de direitos subjetivos uma conseqüência natural.

A doutrina subjetivista já desfrutou de grande prestígio. Para seus seguidores, o escopo direto e imediato do processo é a tutela dos direitos subjetivos, enquanto a atuação da lei seria um efeito indireto, secundário.

Com o desenvolvimento da ciência processual, todavia, não mais se admite tal enfoque, resultado de uma visão eminentemente privatista do processo. $\mathrm{O}$ interesse público na correta atuação da lei deve prevalecer sobre o particular das partes em ver reconhecidos seus direitos. A nova escola processual transformou a maneira de considerar o processo e sua finalidade.”351

O processo deve ser visto, portanto, como um instrumento público voltado à pacificação de conflitos, com justiça. Se a busca da justa pacificação é o objeto do processo, não só às partes cabe a produção probatória, mas também ao juiz, pois sendo o conjunto probatório indispensável a alcançar o escopo fundamental do processo (pacificação com justiça), deve também o órgão jurisdicional concorrer para esta finalidade.

Mais uma vez traz-se à baila a lição de BEDAQUE:

"Hoje, para o processo, como instrumento fundamental do direito processual, em primeiro lugar está o interesse da coletividade, já que sua finalidade é a realização do direito e a paz social. O titular de um interesse

\footnotetext{
350 "Tem dito a doutrina que o mais sólido fundamento do princípio dispositivo parece ser a necessidade de salvaguardar a imparcialidade do juiz. O princípio é de inegável sentido liberal, porque a cada um dos sujeitos envolvidos no conflito sub judice é que deve caber o primeiro e mais relevante juízo sobre a conveniência de demonstrar a veracidade dos fatos alegados. Acrescer excessivamente os poderes do juiz significaria, em última análise, atenuar a distinção entre processo dispositivo e processo inquisitivo. Todavia, diante da colocação publicista do processo, não é mais possível manter o juiz como mero expectador da batalha judicial. Afirmada a autonomia do direito processual e enquadrado como ramo do direito público, e verificada sua finalidade preponderantemente sócio-política, a função jurisdicional evidencia-se como um poder-dever do Estado em torno do qual se reúnem os interesses dos particulares e os do próprio Estado. Assim, a partir do último quartel do século XIX, os poderes do juiz foram paulatinamente aumentados: passando de espectador inerte à posição ativa, coube-lhe não só impulsionar o andamento da causa, mas também determinar provas, conhecer ex officio de circunstâncias que até então dependiam da alegação das partes, dialogar com elas, reprimir-lhe eventuais condutas irregulares etc.” In: ARAÚJO CINTRA, Antonio Carlos de; GRINOVER, Ada Pellegrini; DINAMARCO, Cândido Rangel. Teoria geral do processo. $25^{a}$ ed., São Paulo, Malheiros, 2009, p. 70.

${ }^{351}$ BEDAQUE, José Roberto dos Santos. Poderes instrutórios do juiz, $4^{\mathrm{a}}$ ed.. São Paulo, Revista dos Tribunais, 2009, p. 67-68.
} 
pode ocupar o tempo e as energias dos tribunais estatais, desde que para ele exista a necessidade da tutela jurídica. Aliás, não só as normas ordinárias são atuadas mediante o processo. Ele é um instrumento de atuação da própria Constituição, cujas regras abstratamente formuladas e que representam direitos e garantias fundamentais, concretizam-se processualmente." 352

E conclui, o ilustre professor titular das Arcadas, que:

"Em suma: se todos os integrantes da relação processual têm interesse no resultado do processo, não se deve deixar nas mãos das partes, apenas, a iniciativa instrutória. Ao contrário, tudo aconselha que também o juiz desenvolva atividades no sentido de esclarecer os fatos. Enquanto as partes procuram fazer com que o procedimento se desenvolva segundo seus interesses, o juiz tem em vista o interesse geral.

Justifica-se, portanto, a iniciativa probatória oficial. Quanto melhor os fatos estiverem representados nos autos, maior a possibilidade de um provimento justo, que expresse perfeitamente a regra jurídica do caso concreto. E somente um resultado como esse possibilitaria a verdadeira paz social.”353

Tais ponderações se aplicam com muito mais razão ao processo objetivo, tendo em vista que neste sequer há a defesa de interesses pessoais, particulares, visto que o seu objeto - resguardar e dar efetividade à Constituição - identifica-se com o interesse de toda a coletividade. Assim, é natural e necessário que o magistrado possa livremente determinar a produção de provas e esclarecimentos necessários ao alcance desta finalidade.

VITALINO CANAS, analisando o procedimento perante o Tribunal Constitucional português, entende que tanto o princípio dispositivo como o inquisitório se aplicariam ao controle abstrato de constitucionalidade:

"Por isso, embora princípio dispositivo e princípio inquisitório se contraponham como dois grandes princípios, nada impede que eles apareçam conciliados na estrutura de um determinado processo, cabendo a cada um a predominância em uma ou outra das fases, através de um dos seus subprincípios: na fase de iniciativa pode predominar o princípio do dispositivo através do subprincípio do pedido; na fase de instrução pode

${ }^{352}$ BEDAQUE, José Roberto dos Santos. Poderes instrutórios do juiz, $4^{\mathrm{a}}$ ed.. São Paulo, Revista dos Tribunais, 2009, p. 68.

${ }^{353}$ Ibidem, p. 70-71. 
predominar o princípio inquisitório através do subprincípio da investigação, etc."354

Para CARLOS BLANCO DE MORAES, no processo de controle de constitucionalidade haveria uma preponderância do princípio inquisitivo sobre o dispositivo, decorrente da natureza exclusivamente pública do processo e de seu caráter objetivo. $^{355}$

Todavia, tendo em vista que a disponibilidade diz respeito à relação de direito material ${ }^{356}$ e que, na ação de controle abstrato, os legitimados ativos à propositura das ações de constitucionalidade não são titulares dela, parece-me que o princípio dispositivo sequer possa ser aplicável nesta seara, a não ser, como mencionado alhures, no que diz respeito à disponibilidade para a propositura da ação. Mas esta não está propriamente ligada ao princípio dispositivo e sim à própria natureza da jurisdição ${ }^{357}$ e, no controle abstrato, à necessidade de equilíbrio entre as funções estatais (equilíbrio entre Poderes, $v$. neste sentido os comentários ao princípio da demanda, item 3.2.2, supra). Realmente, não seria correto

${ }^{354}$ CANAS, Vitalino. Os processos de fiscalização da constitucionalidade e da legalidade pelo Tribunal Constitucional: Natureza e princípios estruturantes. Coimbra, Coimbra Editora, 1986, p. 10-102.

355 "Nos processos de fiscalização abstracta, atenta a componente exclusivamente pública e o caráter objectivo do controlo, haveria que reconhecer uma preponderância clara do princípio inquisitório sobre o dispositivo.

Semelhante realidade encontra-se, notadamente, reflectida: na irrelevância processual da ausência de resposta do autor da norma relativamente ao desfecho do processo (de acordo com o art. $54 .^{\circ}$ da LTC, o autor da norma responde, querendo); no corolário da instrução (previsto no art. 58. ${ }^{\circ}$ e seg. da LTC), o qual permite aos juízes indagarem oficiosamente a verdade factual e substancial, 'independentemente do contributo das [...] entidades que [...] introduzam a aç̧ão principal de controlo'; e no critério da repetição do julgado como fundamento do controlo abstracto sucessivo, mediante iniciativa oficiosa dos juízes e do Ministério Público (art. 82. ${ }^{\circ}$ da LTC).” In: MORAES, Carlos Blanco de. Justiça constitucional, t. II. Coimbra, Coimbra Editora, 2005, p. 507-508.

356 “Conclui-se assim que a denominação 'princípio dispositivo' deve expressar apenas as limitações impostas ao juiz, em virtude da disponibilidade do direito; e que são poucas, pois se referem aos atos processuais das partes votados diretamente para o direito disponível. As demais restrições, que no tocante ao início do processo, quer referentes à instrução da causa, não têm qualquer nexo com a relação de material; não decorrem, portanto, do chamado 'princípio dispositivo'. Somente a adoção de um significado diverso para a expressão tornaria possível sua utilização para representar tais restrições”. In: BEDAQUE, José Roberto dos Santos. Poderes instrutórios do juiz. $4^{\text {a }}$ ed., São Paulo, Revista dos Tribunais, 2009, p. 94.

357 "Constitui equívoco afirmar, por exemplo, que a impossibilidade de o juiz dar início ao processo é conseqüência do caráter disponível da relação material. Nela incorre, aliás, a maioria da doutrina.

O monopólio da parte sobre a iniciativa do processo existe independentemente da natureza do direito litigioso. Ainda que indisponível o direito subjetivo material, persiste o princípio da inércia da jurisdição. Isso significa que, mesmo com relação a essa categoria de direitos, o interessado tem o monopólio da demanda. E se o Estado tem interesse direito ou indireto na relação, ainda assim não se confere poder de iniciativa ao juiz. Institui, ele, outro órgão e lhe atribui legitimidade para propor a demanda. É o caso do Ministério Público, por exemplo, que propõe as ações penais e as ações civis públicas. Veja-se que, embora público o interesse em litígio, o magistrado continua inerte”. In: Ibidem, p. 92. 
afirmar que os legitimados à propositura das ações de controle principal podem dispor delas: o interesse de retirar do ordenamento jurídico as normas inconstitucionais não é exclusivo dos legitimados ativos para o processo objetivo; é um interesse de toda a coletividade, portanto, não se trata aqui de direito disponível. Aos legitimados ativos para o controle abstrato é apenas atribuída a prerrogativa que os legitima a dar início à ação.

Na verdade, não há oposição, contraste ou conflito, como bem elucida DINAMARCO, entre a disponibilidade da tutela jurisdicional, que repudia a instauração de processos de ofício pelo juiz e o princípio inquisitivo, "responsável pelo próprio poder jurisdicional estatal a ser exercido sempre que provocado”. ${ }^{358}$ O princípio da demanda e o princípio inquisitório atuam em campos distintos: o primeiro exige a provocação dos legitimados para a instauração do processo - é, portanto, precedente ao processo -; o princípio inquisitivo, por sua vez, refere-se ao modo como o processo é conduzido. ${ }^{359}$

Conclui-se, assim, que o controle abstrato de constitucionalidade identifica-se com os processos de natureza inquisitiva e não com aqueles de cunho dispositivo ou acusatório, fato que é corroborado pela indisponibilidade da própria ação, não sendo facultada ao requerente, uma vez proposta a demanda, a possibilidade de desistência do processo (veja-se o princípio da indisponibilidade, item 3.2.9, infra).

Aos participantes do controle principal, por outro lado, não é atribuído nenhum ônus de movimentar o processo que, portanto, não se extingue por perempção (CPC, art. 267, III), como o processo comum.

Tratando de matéria essencialmente de direito, poderia parecer que não há espaço para a produção probatória. É interessante mencionar que, inicialmente, o

\footnotetext{
${ }^{358}$ DINAMARCO, Cândido Rangel. Instituições de direito processual civil, v. I. 6 ${ }^{a}$ ed., São Paulo, Saraiva, 2009, p. 238-239.

${ }^{359}$ Ibidem, p. 239.
} 
Supremo Tribunal Federal chegou a entender que sequer seria possível a análise de questões de fato no âmbito do processo de controle abstrato. ${ }^{360}$

Todavia, com a aprovação das novas leis que regem os processos objetivos, foram atribuídos ao relator amplos poderes para determinar a produção de provas, com plena liberdade de atuação.

De fato, em sede de controle abstrato de normas, é facultado ao relator determinar, de ofício, a realização de provas. Poderá:

"Em caso de necessidade de esclarecimento de matéria ou circunstância de fato ou de notória insuficiência das informações existentes nos autos, requisitar informações adicionais, designar perito ou comissão de peritos para que emitam parecer sobre a questão, ou fixar data para, em audiência pública, ouvir depoimentos de pessoas com experiência e autoridade na matéria.”361

Na ação direta de inconstitucionalidade e na ação declaratória de constitucionalidade, a lei faculta, igualmente, ao relator a solicitação de informações aos Tribunais Superiores, aos Tribunais federais e aos Tribunais estaduais acerca da aplicação da norma questionada no âmbito de sua jurisdição (Lei federal $n^{\circ} 9.868 / 99$, art. $9^{\circ}$, § $2^{\circ}$ e art. 20, $\left.\S 2^{\circ}\right)$.

Tanto a faculdade de solicitar informações aos Tribunais, como a de resolver controvérsias de fato, não foram reproduzidas na lei da arguição de descumprimento de preceito fundamental (Lei $n^{\circ} 9.882 / 99$, art. $\left.6^{\circ}, \S 1^{\circ}\right) .{ }^{362}$ Todavia, me parece

\footnotetext{
360 "I. Ação direta de inconstitucionalidade: inidoneidade, se dependente da prévia solução de questões controvertidas de fato e de direito local. 1 . O controle direto de constitucionalidade das leis pressupõe a exata compreensão do sentido e do alcance das normas questionadas, a qual há de ser possível de obter-se no procedimento sumario e documental da ação direta. 2. Se, ao contrario, a pré-compreensão do significado da lei impugnada pende da solução de intrincada controvérsia acerca da antecedente situação de fato e de direito sobre a qual pretende incidir, não é a ação direta de inconstitucionalidade a via adequada ao deslinde da quizília. II. Ação direta de inconstitucionalidade: inidoneidade para impugnar ato concreto atinente a uma pluralidade determinada de servidores”. In: ADI 794/GO. Relator Ministro SEPÚLVEDA PERTENCE. Julgamento: 09/12/1992. Órgão Julgador: Tribunal Pleno. Publicação: DJ 21-05-1993, p. 09766, Ement. vol. 01704-02, p. 0279.

${ }^{361}$ Lei $^{\circ} 9.868 / 99$, art. $9^{\circ}$, $\S 1^{\circ}$ (ADI). A este respeito, $v$. também os $\S \S 2^{\circ}$ e $3^{\circ}$ do mencionado artigo, bem como o art. 20, § $1^{\circ}$, da mesma Lei (ADC).

362 “Art. $6^{\circ}$. Omissis.
} 
sejam perfeitamente aplicáveis na arguição de descumprimento, subsidiariamente, caso haja necessidade de tais medidas. De fato, o princípio que vigora em todos estes processos é o mesmo: a ampla investigação probatória, a atribuir ao magistrado liberdade na coleta das provas e elementos elucidativos necessários.

A descrição das diligências pela lei é, ao que tudo indica, exemplificativa, ficando a critério do relator determinar outras medidas que se façam necessárias à instrução da causa. Com a melhor compreensão da matéria, contribui-se para o aumento de qualidade da decisão final, que passa a ser tomada levando em consideração um amplo espectro de conhecimentos que envolvem a matéria.

O Supremo Tribunal Federal tem se valido com regularidade dessa faculdade. Na ADI 4093, na qual se discute a validade de lei estadual paulista que permite a venda, em farmácias e drogarias, de produtos correlatos aos medicamentos, a Ministra relatora, ELLEN GRACIE, considerando a documentação que acompanhava a petição inicial, notou que havia notícia de que a Agência Nacional de Vigilância Sanitária (ANVISA) possuía regramento relacionado ao tema tratado na lei estadual impugnada. Assim, determinou que se oficiasse o Diretor-Presidente daquela agência para que trouxesse aos autos, no prazo de 15 dias, informações referentes ao objeto da lei em exame. ${ }^{363}$

Por outro lado, não há razões para limitar a atuação do magistrado, tendo em vista estar preservada a sua imparcialidade, na medida em que no

$\S 1^{\circ}$ Se entender necessário, poderá o relator ouvir as partes nos processos que ensejaram a arguição, requisitar informações adicionais, designar perito ou comissão de peritos para que emita parecer sobre a questão, ou ainda, fixar data para declarações, em audiência pública, de pessoas com experiência e autoridade na matéria”.

${ }^{363}$ ADI 4093, Rel. Ministra ELLEN GRACIE: “1. O art. 20, § 1을 da Lei 9.868/99 confere ao relator da ação direta de inconstitucionalidade a prerrogativa de buscar informações adicionais para um maior esclarecimento da matéria ou circunstância de fato relacionada com a causa. 2. Na documentação que acompanha a petição inicial (fls. 17-19), há notícia de que a Agência Nacional de Vigilância Sanitária - Anvisa possui regramento que, relacionado ao tema tratado no Diploma estadual impugnado, busca garantir maior controle sanitário na aquisição, armazenamento, conservação e dispensação de produtos industrializados em farmácias e drogarias (Resolução RDC 328, de 22.07.1999, alterada pela Resolução RDC 173, de 08.07.2003). 3. Assim, oficie-se ao Diretor-Presidente da Agência Nacional de Vigilância Sanitária - Anvisa, para que traga aos autos da presente ação direta de inconstitucionalidade informações referentes ao objeto da lei em exame, no prazo de 15 (quinze) dias. Encaminhe-se, com o ofício, cópia da íntegra dos autos. Publique-se. Brasília, 2 de março de 2009.” DJ nº 44 do dia 09/03/2009. 
processo objetivo há um interesse único e comum que paira sobre eventuais interesses dos participantes, que é a preservação da Constituição, de modo a permitir a sua aplicação com máxima efetividade.

Tais medidas (informações, perícias e audiências) deverão ser realizadas no prazo de 30 (trinta) dias, contados da solicitação do relator (Lei federal $n^{\circ}$ 9.868/99, art. $9^{\circ}, \S 3^{\circ}$ e art. $20, \S 3^{\circ}$ ).

Em relação às audiências públicas, não há norma regimental no Supremo Tribunal Federal prevendo a forma de sua realização. Diante de tal omissão, em caso concreto, o Ministro CARLOS BRITTO, proferiu decisão monocrática determinando a utilização do Regimento Interno da Câmara dos Deputados como parâmetro para a audiência (arts. 255 até 258). ${ }^{364}$

\subsubsection{Discussão de matéria relativa a interesses subjetivos específicos}

Esclareça-se que o Supremo Tribunal Federal tem entendido que o controle abstrato de constitucionalidade não é o cenário para discussão de interesses subjetivos, chegando a extinguir ações sem exame do mérito diante da verificação de que o real escopo do autor seria buscar a satisfação de interesses subjetivos ou pessoais.

Realmente, na ADI 3.867/RJ ${ }^{365}$ a relatora, Ministra CÁRMEN LÚCIA, negou seguimento à ação em virtude de, por meio dela, “não se buscar, efetivamente,

${ }^{364}$ ADI 3510, Relator: Ministro CARLOS BRITTO, decisão monocrática, julgamento em 16-3-07, DJ de 30-307.

${ }^{365}$ Nesta ADI, o autor, partido político com representação no Congresso Nacional, alegou ofensa ao ato jurídico perfeito, à coisa julgada e ao direito adquirido, em virtude de o Governo do Estado do Rio de Janeiro ter estabelecido um "teto" para a remuneração e os proventos dos fiscais de rendas do Estado, e formulou pedido com vistas a impedir a aplicação retroativa dos dispositivos da EC 41/03, de modo a restabelecer a fixação do limite ou teto das remunerações e proventos dos fiscais de rendas como previsto pelo art. 37, XI, da Constituição Federal em sua redação originária e, ainda, garantir a exclusão dos direitos e vantagens pessoais do teto das suas remunerações e proventos, como era estabelecido no art. 39, § $1^{\circ}$ da Constituição da República. 
o controle abstrato de constitucionalidade, mas decisão judicial para atendimento de interesses subjetivos específicos”. 366

Nesse caso, o próprio pedido me parece ter sido formulado equivocadamente, pois o autor pleiteava o retorno ao status quo ante em relação ao padrão remuneratório da categoria de servidores públicos interessada. Aí está evidente a defesa, imprópria, de interesses individuais.

Em outra oportunidade, em processo relatado pelo Ministro CELSO DE MELLO, a Confederação Nacional da Indústria impugnou dispositivos da Lei $n^{\circ}$ 10.165, de 27/12/2000, que alterou dispositivos pertinentes da Lei $n^{0} 6.938 / 81$, referentes à Política Nacional do Meio Ambiente. Em brevíssima síntese, sustentava a autora que a nova lei violava dispositivos da Constituição Federal que tratam de matéria tributária (art. 145, II; 167, IV; 153; e 154, I), tendo impropriamente criado uma nova taxa. Entendeu o Ministro Relator que a simples narração de situações reveladoras de pretensão de defesa de direitos individuais ${ }^{367}$ revelariam de forma inquestionável “o intuito da autora de, ao agir em sede de

\footnotetext{
${ }^{366}$ Da decisão extrai-se o seguinte trecho: "O pedido formulado pelo Autor, por si só, é suficiente para indicar a busca de soluções concretas e individuais. O Partido Democrático Trabalhista-PDT pede não a declaração de inconstitucionalidade dos arts. $3^{\circ}$ e $5^{\circ}$ da Emenda Constitucional n. 19/1998 e $8^{\circ}$ e $9^{\circ}$ da Emenda n. 41/03, mas, sim, o restabelecimento 'do limite ou teto das remunerações e proventos dos Fiscais de Rendas como previsto pelo art. 37, XI, da Constituição [da República]' (fl. 42). Assim, o que pretende o Autor é a defesa de interesses subjetivos dos fiscais de rendas do Estado do Rio de Janeiro. Este Supremo Tribunal Federal assentou entendimento segundo o qual não se há de acolher a defesa de interesses subjetivos em ação prestante ao controle abstrato da validade de normas em face da Constituição da República. Nessa via, não se há de decidir sobre os interesses ou os direitos de partes específicas, mas da validade das normas em face da Constituição. Entender o contrário seria burlar o fim verdadeiro da lide.” In: ADI 3867/RJ-RIO DE JANEIRO, Relatora: Min. CÁRMEN LÚCIA. Julgamento: 22/02/2008. Publicação: DJe-036 DIVULG 28/02/2008 PUBLIC 29/02/2008.

367 Veja-se o seguinte trecho da R. Decisão: "Impõe-se analisar, inicialmente, questão pertinente à utilização adequada da ação direta de inconstitucionalidade, pois tenho para mim - a partir da leitura da petição inicial e dos documentos que a instruem - que este processo de controle concentrado foi instaurado com o iniludível objetivo de promover, em sede de fiscalização abstrata, a defesa de interesses individuais e concretos das empresas vinculadas, no plano da organização sindical, à autora, notadamente 'as empresas de pequeno e médio portes' (fls. 38), e, em particular, a Companhia Vale do Rio Doce, como se depreende do seguinte fragmento constante da peça processual mencionada (fls. 34/35): 'Os valores estipulados pela Lei 10.165/00, a título de TCFA, a par das inconstitucionalidades já apontadas, inobservam outro princípio jurídico, que é o princípio da proporcionalidade ou da razoabilidade que deve informar a elaboração de atos normativos, sobretudo porque estipula a lei que a taxa seja cobrada por estabelecimento (art. 17- D), o que certamente conduzirá a valores exorbitantes, se considerarmos, por exemplo, uma grande empresa com estabelecimentos em todo o País. Vejase, assim, a Companhia Vale do Rio Doce que deverá recolher anualmente, a título de TCFA, o valor absurdo de cerca de R\$ 1.200.000,00 (hum milhão e duzentos mil reais)!!! (Doc. 11). E esse valor, é bom destacar, excluiu os estabelecimentos administrativos e comerciais.' (grifei) Registre-se, ainda, por necessário, que esse específico
} 
fiscalização concentrada, buscar, na realidade, amparo jurisdicional para a preservação de direitos e interesses concretos das empresas que, vinculadas à CNI, serão afetadas, em suas respectivas situações individuais, pelo diploma legislativo ora impugnado", ${ }^{368}$

Assim, para o Ministro Relator a configuração concreta de interesses individuais contrastantes bastaria, por si só, para inviabilizar a utilização da ação direta de inconstitucionalidade. ${ }^{369}$

Não parece razoável que o simples fato de a inicial da ação direta narrar efeitos concretos da inconstitucionalidade ou situações concretas que afetam a parte ou terceiros sejam suficientes para inviabilizar a utilização do controle principal de constitucionalidade. Realmente, embora a narrativa desses fatos possa revelar-se desnecessária à configuração do conflito de normas, a sua mera menção na petição inicial não me parece suficiente a inviabilizar o uso do processo de controle abstrato ${ }^{370}$, desde que o pedido esteja corretamente formulado, no sentido da declaração pura e simples de inconstitucionalidade dos dispositivos impugnados. Em certas situações, a narrativa dos efeitos pode, com a devida vênia, até mesmo evidenciar melhor a amplitude e gravidade da violação a determinado

propósito que anima a autora - especialmente se se considerarem os fundamentos que dão suporte à presente argüição de inconstitucionalidade - resulta claro dos documentos que instruem a própria petição inicial, nos quais são relacionadas, concretamente, várias empresas registradas na FEEMA, com menção, inclusive, a planilhas 'com a previsão dos gastos anuais de quatro destas empresas' (fls. 82), seguindo-se observação de que seria encaminhado à CNI, 'para subsidiar a Ação Direta de Inconstitucionalidade - ADIn que será movida por esta Confederação contra a Lei n. 10.165/00, que cria a Taxa de Controle e Fiscalização Ambiental - TCFA, a ser cobrada pelo IBAMA' (fls. 82), um 'estudo [...] referente à média a ser paga, anualmente, pelas indústrias fluminenses...' (fls. 82)."

${ }^{368}$ ADI 2422/DF - DISTRITO FEDERAL. Relator Ministro CELSO DE MELLO. Julgamento: 01/08/2001. Publicação: DJ 15/08/2001, p. 06.

369 "Veja-se, pois, que o contexto ora exposto põe em evidência a configuração concreta de interesses individuais contrastantes, o que basta, por si só, para inviabilizar a utilização, na espécie em exame, da ação direta de inconstitucionalidade.” In: ADI 2422/DF - DISTRITO FEDERAL. Relator Ministro CELSO DE MELLO. Julgamento: 01/08/2001. Publicação: DJ 15/08/2001, p. 06.

${ }^{370}$ VITALINO CANAS esclarece que: "Não se exclui que a par do interesse público haja interesses particulares que com ele concorram no mesmo ou em sentido diverso. Mas tais interesses não adquirem qualquer relevância processual negativa ou positiva. Desse modo, se acidentalmente se vier detectar que foram intuitos de natureza pessoal (por exemplo, a procura de proventos políticos resultantes de um acréscimo de prestígio junto da opinião pública, designadamente dos eleitores) que declaradamente decidiram a entidade a accionar o mecanismo de fiscalização, em nada isso vem repercutir-se na obrigação de o Tribunal Constitucional se debruçar sobre a questão, estando impedido de rejeitar só por essa razão a admissibilidade do requerimento.” In: CANAS, Vitalino. Os processos de fiscalização da constitucionalidade e da legalidade pelo Tribunal Constitucional: Natureza e princípios estruturantes. Coimbra, Coimbra Editora, 1986, p. 28. 
dispositivo constitucional, bem como demonstrar a necessidade de concessão de tutela cautelar.

\subsubsection{Análise das prognoses legislativas}

A premissa de que, em sede de controle abstrato de constitucionalidade, no qual a questão constitucional é examinada em tese, não haveria espaço para a análise de fatos não se revela, assim, correta.

Pode-se dizer que se trata de noção superada. Segundo doutrina e jurisprudência atuais, tem-se entendido que a análise dos fatos no âmbito do processo objetivo é não só perfeitamente aceitável como, muitas vezes, imprescindível à realização do controle. $^{371}$

FERREIRA MENDES cita diversos exemplos da jurisprudência internacional no qual o exame de fatos e prognoses legislativas foi decisivo para a elucidação das questões colocadas à apreciação do tribunal constitucional. Caso emblemático foi o Brandeis-brief, nos Estados Unidos. Como bem elucida o ilustre Ministro do STF, tratava-se de:

“memorial utilizado pelo advogado Louis D. Brandeis, no 'case Müller versus Oregon’ (1908), contendo duas páginas dedicadas às questões

${ }^{371}$ GILMAR FERREIRA MENDES defende que: “Em verdade, há muito vem parte da dogmática apontando para a inevitabilidade da apreciação de dados da realidade no processo de interpretação e aplicação da lei como elemento trivial a própria metodologia jurídica.

É verdade que, às vezes, uma leitura do modelo hermenêutico clássico manifesta-se de forma radical, sugerindo que o controle de normas há de se fazer com o simples contraste entre a norma questionada e a norma constitucional superior. Essa abordagem simplificadora tem levado o Supremo Tribunal Federal a afirmar, às vezes, que fatos controvertidos ou que demandam alguma dilação probatória não podem ser apreciados em ação direta de inconstitucionalidade.

Essa abordagem confere, equivocadamente, maior importância a uma pré-compreensão do instrumento processual do que à própria decisão do constituinte de lhe atribuir a competência para dirimir a controvérsia constitucional.” In: MENDES, Gilmar Ferreira. Direitos fundamentais e controle de constitucionalidade. $3^{\mathrm{a}}$ ed., São Paulo, Saraiva, 2006, p. 471. 
jurídicas e outras 110 voltadas para os efeitos da longa duração do trabalho sobre a situação da mulher - permitiu que se desmistificasse a concepção dominante, segundo a qual a questão constitucional configurava simples 'questão jurídica' de aferição de legitimidade da lei em face da Constituição.”372

Da constatação da necessidade de verificação de fatos no controle abstrato de normas decorre outra característica incindível desse processo, que deve, necessariamente, estar aberto à participação de terceiros juridicamente interessados. Assim, o processo objetivo deve adotar "um modelo procedimental aberto que outorgue ao Tribunal as condições necessárias para proceder a essa aferição”. ${ }^{373}$

Ampliarei a análise dessa proposta no tópico voltado ao contraditório (item 3.2.10, infra).

\subsubsection{O princípio da indisponibilidade [Lei federal $n^{\circ} 9.868 / 99$, art. $5^{\circ}$ (ADI) e art. 16 (ADC)]}

Uma vez proposta a ação, seguindo os requisitos acima mencionados, poderia o requerente voltar atrás, desistindo dela?

Em sua formulação clássica, o princípio da demanda leva à consequência de que também a continuação do processo dependeria da vontade do requerente. Todavia, em sede de controle abstrato de constitucionalidade esse desdobramento não é aplicável.

Inicialmente, como relata GILMAR FERREIRA MENDES, o Supremo Tribunal Federal admitiu a possibilidade de desistência da ação proposta, tendo se

\footnotetext{
${ }^{372}$ MENDES, Gilmar Ferreira. Direitos fundamentais e controle de constitucionalidade. $3^{\text {a }}$ ed., São Paulo, Saraiva, 2006, p. 472.

${ }^{373}$ Ibidem, p. 480.
} 
afastado deste entendimento posteriormente, sendo certo que, desde 1970, o Regimento Interno consagra, expressamente, a inadmissibilidade da desistência da ação (RISTF, art. 169, $\left.\S 1^{\circ}\right) .{ }^{374}$

No controle abstrato, a natureza objetiva do processo indica que o demandante não está buscando um interesse próprio, mas, sim, um bem jurídico mais altaneiro, que se identifica com a higidez constitucional, ou seja, a defesa da regularidade do próprio texto constitucional.

Assim, nas ações declaratórias de constitucionalidade, doutrina e jurisprudência $^{375}$ têm entendido que o requerente não tem disponibilidade sobre a ação, não havendo possibilidade de desistência. Aplica-se, nesse caso, o princípio da indisponibilidade, que abrange, inclusive, a desistência do pedido de medida cautelar. ${ }^{376}$

Nesse sentido, há previsão expressa na Lei federal nº 9.868/99, referente aos arts. $5^{\circ}$ (ADI) e 16 (ADC). ${ }^{377}$ Todavia, a lei que disciplina a arguição de descumprimento de preceito fundamental não possui dispositivo semelhante. Ao que tudo

\footnotetext{
${ }^{374}$ MENDES, Gilmar Ferreira. Jurisdição constitucional. 5a ed;, São Paulo, Saraiva, p. 149. No trecho, o autor faz referência ao seguinte julgado, no qual o Pretório Excelso admitiu a desistência da ação: Rp. 287, Relator Min. NÉLSON HUNGRIA, DJ. 16/04/1958.

${ }^{375}$ Neste sentido, veja-se o seguinte julgado: “O processo de controle normativo abstrato rege-se pelo princípio da indisponibilidade. A questão pertinente à controvérsia constitucional reveste-se de tamanha magnitude, que, uma vez instaurada a fiscalização concentrada de constitucionalidade, torna-se inviável a extinção desse processo objetivo pela só e unilateral manifestação de vontade do autor. [...] Tenho para mim que as mesmas razões que afastam a possibilidade da desistência em ação direta justificam a vedação a que o autor, uma vez formulado o pedido de medida liminar, venha a reconsiderar a postulação deduzida initio litis.” In: ADI 892-MC, voto do Ministro CELSO DE MELLO, julgamento em 27-10-94, DJ de 7-11-97. E, ainda: "O princípio da indisponibilidade, que rege o processo de controle concentrado de constitucionalidade, impede a desistência da ação direta já ajuizada. O art. 169, § $1^{\circ}$, do RISTF-80, que veda ao Procurador-Geral da República essa desistência, aplica-se, extensivamente, a todas as autoridades e órgãos legitimados pela Constituição de 1988 para a instauração do controle concentrado de constitucionalidade (art. 103).” In: ADI 387-MC, Rel. Ministro CELSO DE MELLO, julgamento em $1^{\circ}-3-91, D J$ de 11-10-91). No mesmo sentido: ADI 1.368-MC, Rel. Ministro NÉRI DA SILVEIRA, julgamento em 19-12-95, DJ de 19-12-96 e ADI 164, Rel. Ministro MOREIRA ALVES, julgamento em 8-9-93, DJ de 17-12-93.

376 "Não é possível atender à súplica de limitação do pleito liminar. Proposta a ação direta de inconstitucionalidade, é indisponível seu objeto, parcial ou totalmente.” In: ADI 2049 MC/RJ. Relator: Ministro NÉRI DA SILVEIRA. Julgamento: 14/04/2000. Órgão Julgador: Tribunal Pleno. Publicação: DJ 31-08-2001, p. 035, Ement. vol. 02041-02, p. 0260.

${ }^{377}$ Também o Regimento Interno do STF possui disposição neste sentido: “Art. 169 Omissis. §1: Proposta a representação, não se admitirá desistência, ainda que ao final o Procurador-Geral se manifeste pela sua improcedência."
} 
indica, no caso da arguição de descumprimento de preceito fundamental autônoma, seria de se aplicar a mesma regra, não havendo motivo para entendimento diferenciado. ${ }^{378} 379$

No processo de controle abstrato não é cabível, outrossim, a transação. O abandono do pleito pelo autor não acarreta a extinção do processo tal qual ocorre no processo civil $^{380}$, sendo inaplicável esta regra nas ações diretas de controle de constitucionalidade.

3.2.10 O princípio do contraditório [CF, art. $5^{\circ}, \mathrm{LV}$; Lei federal $\mathrm{n}^{\circ} 9.868 / 99$, art. $6^{\circ}$, art. $7, \S 2^{\circ}$, art. $8^{\circ}$, art. 10 , caput e $\S 1^{\circ}$, e art. 12 (todos acerca da ADI); art. 14, III e art. $20, \S$ $1^{\circ}$ (ADC) e Lei federal $n^{\circ} 9.882 / 99$, art. $5, \S 2^{\circ}$, art. $6^{\circ}$, caput e $\S 1^{\circ}$ ]

É praticamente unânime perante a doutrina processual a noção de que o contraditório deve se fazer presente em todo e qualquer processo, jurisdicional ou não (CF, art. 5 LV). Em virtude de se tratar de garantia constitucional, exige-se a instauração do contraditório em relação a todos aqueles detentores de interesses diretamente atingíveis pelos efeitos do provimento judicial solicitado, a fim de que tenham a oportunidade de se contrapor ao pedido.

\footnotetext{
378 “À argüição, seja em qualquer de suas modalidades, igualmente, há de se aplicar essa mesma orientação já adotada para os demais processos de controle objetivo da constitucionalidade, e agora constante de texto normativo expressamente, máxime tendo em consideração destinar-se a novel medida à defesa do conjunto de preceitos basilares do sistema jurídico-constitucional. Se para a defesa das demais normas constitucionais não se admite a desistência, não se poderia admiti-la quando da defesa objetiva das normas fundamentais da Constituição. Aplica-se, pois, por falta de norma expressa na Lei n. 9,882/99, e por força do entendimento já sufragado pelo Supremo Tribunal Federal antes mesmo da referida legislação, a vedação à desistência por parte do autor da argüição.” In: TAVARES, André Ramos. Tratado da argüição de descumprimento de preceito fundamental. São Paulo, Saraiva, 2001, p. 356.

${ }^{379}$ Todavia, o Supremo Tribunal Federal possui precedente admitindo a desistência da ação: ADPF 108/RJ. Relator: Ministra CÁRMEN LÚCIA. Julgamento: 13/04/2007. Publicação: DJe-002, divulgação: 24/04/2007, publicação: 25/04/2007. DJ 25/04/2007, p. 026. Ao que tudo indica, todavia, parece tratar-se de situação de alto grau de particularidade.

${ }^{380}$ CPC, art. 267, II e III.
} 
Processualistas de renome, como a Prof ${ }^{\mathrm{a}}$ ADA PELLEGRINI GRINOVER, entendem que o exercício do poder público, como mencionou em palestra proferida no XV Encontro de Direito Constitucional, promovido pela Associação Brasileira dos Constitucionalistas - Instituto Pimenta Bueno -, realizado em setembro de 2006, deve, sempre, ser precedido de contraditório.

Por outro lado, em sede de controle concentrado de constitucionalidade, tanto a doutrina como o Supremo Tribunal Federal entendem tratar-se de um processo objetivo, sem partes, no qual não haveria, em princípio, espaço para o exercício do contraditório, ao menos em sua fórmula clássica audiatur et altera pars.

Afirma-se, de maneira quase generalizada, que no processo objetivo os participantes se voltariam à preservação do texto constitucional, não havendo que se falar em defesa de interesses particulares, nem tampouco no contraditório.

Ao caracterizar o controle abstrato de constitucionalidade CANOTILHO defende a ausência do contraditório de partes nesta espécie de processo:

"Relacionado com o controlo concentrado e principal, o controlo abstrato significa que a impugnação da constitucionalidade de uma norma é feita independentemente de qualquer litígio concreto. O controlo abstrato de normas não é um processo contraditório de partes; é, sim, um processo que visa sobretudo ‘a defesa da constituição' e da 'legalidade democrática' através da eliminação de actos normativos contrários à constituição. Dado que se trata de um processo objectivo, a legitimidade para solicitar este controlo é geralmente reservada a um número restrito de entidades.”381

Em outra parte, o mestre português esclarece melhor que o contraditório que não tem lugar no processo abstrato é aquele identificado com o litígio para a defesa de interesses subjetivos, ressaltando, por outro lado, que as autoridades responsáveis pela edição dos atos normativos podem ser ouvidas:

${ }^{381}$ CANOTILHO, José Joaquim Gomes. Direito constitucional e teoria da Constituição. $7^{\mathrm{a}}$ ed., Coimbra, Almedina, 2003, p. 900 (grifo nosso). 
"Não obstante se ter falado de legitimidade processual activa e de legitimidade processual passiva, o processo abstracto de controlo de normas não é um processo contraditório, no qual as partes 'litigam' pela defesa de direitos subejectivos ou pela aplicação de direito subjectivamente relevante. Trata-se, fundamentalmente, de um processo objectivo sem contraditores, embora os autores do acto normativo submetido a impugnação possam ser ouvidos (daí a utilidade de se falar em legitimidade processual passiva). Mas o processo principal de fiscalização abstracta não é um processo contraditório (embora, nos termos do art. $54^{\circ}$ da LTC esteja assegurado o princípio audiatur et altera pars, ou seja, o princípio do contraditório).”382

Em obra editada pouco após a promulgação da Constituição de 1988, GILMAR FERREIRA MENDES traz à baila entendimento de forte inspiração na doutrina alemã, voltado a demonstrar o caráter objetivo e desprovido de contraditório do processo de controle abstrato:

"Evidentemente, como órgão político competente para instaurar o controle abstrato de normas, o Procurador-Geral da República não veicula uma pretensão propriamente dita, traduzindo, apenas, o interesse público na apreciação da validade da lei ou do ato normativo. Não há que se cogitar, pois, de um contraditório, afigurando-se suficiente o interesse manifestado na apreciação da validade da norma pelo Supremo Tribunal Federal.

[...]

Não se deve olvidar, ainda, que norma regimental da Excelsa Corte incorporou dispositivo constante - equivocadamente, a nosso ver - da lei n. 4.337/64, que faculta ao relator dispensar informações, em caso de relevante interesse da ordem pública (RISTF, art. 170, $\S 3^{\circ}$ ). Sem dúvida, tal disposição destaca, ainda mais, o caráter objetivo do processo de controle abstrato de normas, ensejando o julgamento da representação sem a configuração de um contraditório mínimo." ${ }^{383}$

Perante o Supremo Tribunal Federal, GILMAR FERREIRA MENDES, então Procurador da República, sustentou posição semelhante, ainda sob a égide da Constituição de 1967/1969:

"Vê-se, pois, que tal como concebido pelo constituinte e desenvolvido pelo Supremo Tribunal Federal, o controle abstrato de normas, previsto no art. 119, I, l, do Texto Magno, configura processo objetivo, não contraditório, destinado, exclusivamente, à defesa da ordem constitucional. 'O Procurador-

${ }^{382}$ CANOTILHO, José Joaquim Gomes. Direito constitucional e teoria da Constituição. $7^{\mathrm{a}}$ ed., Coimbra, Almedina, 2003, p. 1007-1008.

${ }^{383}$ MENDES, Gilmar Ferreira. Controle de constitucionalidade: Aspectos jurídicos e políticos. São Paulo, Saraiva, 1990, p. 258 (grifos nossos). 
Geral da República é o titular dessa representação - ressalta a Excelsa Corte - apenas para o efeito de provocar, ou não’ (AR N. 878, RTJ 94/58). O processo de controle abstrato de normas constitui, também entre nós, um autêntico processo sem partes (ein Verfahren ohne Beteiligte). (Cf., a propósito, Söhn, op. cit., p. 304; v. também, Embargos na Rp. 1.092, Rel. Min. Néri da Silveira, RETJ 117/921; Cf., especificamente, voto preliminar do Ministro Moreira Alves, RT 117/952).”384

No mesmo sentido, o Ministro MOREIRA ALVES, já sobre o manto da Constituição de 1988, ao relatar questão de ordem suscitada na ação declaratória de constitucionalidade 1 , em que se discutia a constitucionalidade da própria Emenda Constitucional 3, instituidora daquela modalidade de ação, sustentou a inaplicabilidade do princípio do contraditório nos processos de controle abstrato. Afirmou, naquela oportunidade, que a ação direta de inconstitucionalidade se apresentava como processo objetivo, no qual não haveria:

"prestação de jurisdição em conflito de interesses que pressupõem necessariamente partes antagônicas, mas em que há, sim, a prática, por fundamentos jurídicos, do ato político de fiscalização dos Poderes constituídos decorrente da aferição da observância, ou não, da Constituição pelos atos normativos deles emanados”. ${ }^{385}$

Sustentou, outrossim, o ilustre Ministro que no processo de controle abstrato não há partes contrapostas, citando o entendimento doutrinário de JEANCLAUDE BÉGUIN em sustento desta tese:

“E JEAN-CLAUDE BÉGUIN (Le Contrôle de la Constitutionnalité des Lois em République Fédérale d'Allemagne, p. 61, Paris, 1982), após salientar que, no controle abstrato de normas, não há partes contrapostas, observa que 'a audiência dos representantes dos órgãos constitucionais interessados em razão de sua participação na elaboração ou na aplicação da norma não teria por conseqüência dar a qualidade de parte num processo que não conhece isso' ('L'audition des représentants des organes constitucionnels intéressés en raison de leur participation à l'élaboaration ou à l'application de la norme, ne saurait avoir pour conséquence de donner la qualité de partie dans une procédure qui n'en connaît pas').

[...]

\footnotetext{
${ }^{384}$ MENDES, Gilmar Ferreira. Moreira Alves e o controle de constitucionalidade no Brasil. São Paulo, Celso Bastos Editor, 2000, p. 191, (grifo nosso).

${ }^{385}$ ADC 1 QO/DF, Relator Ministro MOREIRA ALVES. Julgamento: 27/10/1993. Órgão Julgador: Tribunal Pleno. Publicação: DJ 16/06/1995, p. 18212. Ement. vol. 01791-01, p. 01.
} 
Foi, aliás, por entender que nesse processo objetivo não há propriamente partes que este Tribunal, sendo relator o Sr. Ministro Néri da Silveira, admitiu, nos embargos na representação de inconstitucionalidade n. 1092 (RTJ 117/921 e segs.), que o Procurador-Geral da República, que havia proposto a representação, mas lhe dera parecer pela improcedência, tinha legitimidade, embora não sucumbente, para interpor embargos infringentes ao acórdão que julgara a representação.”386

Ressalta, ainda, que a ausência do sujeito passivo da relação processual, isto é, o órgão do qual emanou a norma impugnada, não descaracterizaria a ação direta de inconstitucionalidade, em virtude de não ser a sua oitiva imprescindível:

\begin{abstract}
"Igualmente, com relação ao sujeito passivo, sua ausência não descaracteriza a ação direta de inconstitucionalidade. Ela pode decorrer da dispensa do pedido de informações ao Poder ou órgão de que emana o ato normativo impugnado, e dispensa essa que é admitida pelo Regimento Interno deste Tribunal (artigo 170, $\S 2^{\circ}$, in fine, e artigo 172). Como também, nessa ação, podem ocorrer hipóteses em que os legitimados ativo e passivo se confundem, o que implica, em última análise, a inexistência de legitimado passivo. Assim, por exemplo, se um Governador de Estado impugnar como inconstitucional ato normativo de seu antecessor, caso em que o requerente não pode ser, ao mesmo tempo, o requerido. E também não ocupa a posição formal de réu o advogado-geral da União, que não é parte, mas curador da presunção de constitucionalidade do ato normativo atacado.

Portanto, também na ação direta de inconstitucionalidade, embora as mais das vezes haja legitimado passivo - o Poder ou órgão que elaborou o ato normativo -, não é ele imprescindível.” 387
\end{abstract}

No que concerne à ação declaratória de constitucionalidade, cuja constitucionalidade então se colocava à prova, aduziu o Ministro MOREIRA ALVES que, nesta espécie, a ausência do legitimado passivo não seria eventual, mas ocorreria sempre, o que, no seu entender: "se coaduna, como já vimos, com a natureza do processo objetivo, a saber, a de um processo essencialmente unilateral, não-contraditório, sem partes, no qual há um requerente, mas não há necessariamente um requerido”. 388

\footnotetext{
${ }^{386}$ ADC 1 QO/DF, Relator Ministro MOREIRA ALVES. Julgamento: 27/10/1993. Órgão Julgador: Tribunal Pleno. Publicação: DJ 16/06/1995, p. 18212. Ement. vol. 01791-01, p. 01.

${ }^{387}$ Ibidem (grifo nosso).

${ }^{388}$ ADC 1 QO/DF, Relator Ministro MOREIRA ALVES. Julgamento: 27/10/1993. Órgão Julgador: Tribunal Pleno. Publicação: DJ 16/06/1995, p. 18212. Ement. vol. 01791-01, p. 01.
} 
Todavia, me parece que essas assertivas devem ser recebidas com alguma reserva.

Os entendimentos que concluem pela inaplicabilidade do contraditório no processo objetivo de controle de constitucionalidade apegam-se apenas a parte do conteúdo normativo deste princípio, que é voltada exclusivamente à defesa de interesses parciais e particulares, consistente na regra que prevê a ciência bilateral dos atos e termos do processo e possibilidade de reação, com vista à defesa de interesses particulares.

Todavia, o princípio do contraditório contém uma gama muito maior de normatividade, em meu sentir perfeitamente aplicável ao controle abstrato de normas.

De fato, inicialmente, como menciona TAVEIRA BERNARDES, pode-se citar três valores garantidos pelo contraditório: informação (conhecimento da demanda e chance de participação); possibilidade de reação - quanto aos atos praticados pelos sujeitos e/ou agentes auxiliares do processo; e paridade de armas. ${ }^{389}$

Segundo o seu entender, ao menos o direito à informação e o direito à paridade de armas, decorrentes do contraditório, subsistem no controle abstrato de constitucionalidade. $^{390} \mathrm{E}$, como procurarei demonstrar a seguir, mesmo a possibilidade de reação seria igualmente aí cabível.

Primeiramente, a partir do momento em que se reconhece a natureza pública do processo - voltada à pacificação de litígios, com justiça - há que se concluir, forçosamente, -que, em toda espécie de processo, os participantes buscam a preservação e realização dos valores constitucionalmente previstos, como a justiça, a

\footnotetext{
${ }^{389}$ BERNARDES, Juliano Taveira. Controle abstrato de constitucionalidade: Elementos materiais e princípios processuais. São Paulo, Saraiva, 2004, p. 293.

${ }^{390}$ Ibidem, p 293.
} 
igualdade, a dignidade de pessoa humana e todo o seu espectro de consequências. ${ }^{391}$ Dessa forma, também em um processo comum, todos atuariam em um sentido único, de realização da justiça, pois se pretendessem se valer do processo para fins ilícitos, inverídicos, temerários, infundados ou protelatórios, estariam sujeitos às penas processuais (CPC, art. 17).

Afinal, como já se mencionou, com muita propriedade, “o processo não é um jogo, em que o mais capaz sai vencedor, mas um instrumento de justiça, com o qual se pretende encontrar o verdadeiro titular de um direito”. 392

Hoje se tem a clara noção de que a relação de direito processual é totalmente independente da de direito material, sendo certo que, na relação processual buscase satisfazer não somente o interesse das partes, mas, principalmente, o interesse público, motivo pelo qual, como bem esclarece BEDAQUE, o processo deve, necessariamente, voltarse à obediência da ordem pública estabelecida. ${ }^{393}$

Por sua vez, a tese no sentido de que os participantes do controle abstrato de constitucionalidade atuariam com o mesmo objetivo, matizado na preservação da ordem constitucional, é, no mínimo, discutível. De fato, embora o objetivo de todo o processo seja a realização de valores como a justiça ou a proteção da ordem constitucional, é natural que os participantes tenham uma visão distinta do que seja, efetivamente, a realização prática destes valores.

\footnotetext{
${ }^{391}$ Vide, nesse sentido, os comentários e citações feitos no item 3.2.8, supra (O princípio da livre investigação das provas e o princípio inquisitivo).

${ }^{392}$ BEDAQUE, José Roberto dos Santos. Poderes instrutórios do juiz, $4^{\mathrm{a}}$ ed.. São Paulo, Revista dos Tribunais, 2009, p. 101-102.

393 “Assim, a relação processual tem seu próprio objeto, que jamais é o mesmo da relação de direito material. Pode esta pertencer ao direito público ou privado, não importa. O processo, entendido como relação processual mais procedimento, ou como procedimento realizado em contraditório, tem sempre a mesma finalidade a ser atingida: a manutenção do ordenamento jurídico, do que advém a afirmação da autoridade do Estado e a paz social. A relação processual é, portanto, completamente independente da de direito material. O que existe é uma relação de instrumentalidade entre o processo e o direito material, pois aquele vista à atuação deste. E essa finalidade satisfaz não apenas o interesse das partes cujas relações são reguladas pelas normas de direito material, mas, principalmente, o interesse público na obediência à ordem jurídica estabelecida. Aliás, esse último se sobrepõe ao primeiro.” In: Ibidem, p. 68-69.
} 
Mesmo no processo objetivo, no qual a preservação da Constituição é o objetivo comum, cada um dos participantes pode almejar, como resultado do processo, um provimento completamente distinto dos demais.

Veja-se, por exemplo, a seguinte situação: o Governo obtém no Congresso a aprovação de determinado projeto de lei que institui uma nova espécie tributária. Partidos de oposição entendem que a exação enseja a bitributação, motivo pelo qual recorrem ao Poder Judiciário, por meio de ação direta de inconstitucionalidade, requerendo a invalidação da lei. Serão prestadas informações pelos responsáveis pela edição da lei (Poderes Executivo e Legislativo) que, certamente, terão interesse em sustentar a tese voltada a demonstrar a sua constitucionalidade, em contraponto ao pedido inicial, no sentido de sua invalidação.

Verifica-se, claramente, que a decisão final proferida nos processos de controle abstrato não poderá atender integralmente às pretensões de todos os envolvidos. A única aspiração comum que todos os interessados poderão ter atendida é a de que o processo se desenvolva em consonância com os princípios e regras constitucionais, seguindo o rito previsto em lei, perante um órgão constitucionalmente competente e anteriormente investido em sua função (princípio do juiz natural), por meio do qual possam expor a sua tese acerca da adequação constitucional do ato normativo (princípio do contraditório, ainda que visto de forma objetiva). ${ }^{394}$

Se determinado ato normativo é inquinado de inconstitucional, o órgão do qual emanou, v. g., do Poder Legislativo, tem inegável interesse em infirmar a tese de sua inconstitucionalidade.

Realmente, para a aprovação de uma lei, é necessário, como se sabe, seja submetida a um processo legislativo complexo. O projeto de lei devidamente proposto é submetido à apreciação de diversas comissões temáticas, nas quais recebe

\footnotetext{
394 Quanto à legitimidade trazida pelo procedimento, veja-se: LUHMANN, Niklas. Legitimação pelo Procedimento. Brasília, Editora Universidade de Brasília, 1980.
} 
pareceres - inclusive quanto à sua constitucionalidade (parecer imprescindível à aprovação, a cargo da Comissão de Constituição de Justiça ou congênere - no Senado Federal e na Câmara dos Deputados são denominadas Comissão de Constituição, Justiça e Cidadania). Em seguida, desde que sanados eventuais vícios e estando a propositura formalmente em ordem, é submetida à apreciação do plenário, requerendo, para ser aprovada, o voto da maioria, simples ou absoluta, dos parlamentares, ou, ainda, alcançar o quórum qualificado de votos, quando for o caso.

Em âmbito federal, o projeto ainda precisa ser aprovado pela Casa legislativa revisora (Câmara ou Senado, dependendo de onde teve início a tramitação do projeto, conforme previsto no art. 65 da Constituição federal de 1988).

A final, o projeto, se aprovado, é remetido à apreciação do chefe do Poder Executivo, para sanção ou veto (CF, art. 66). Se vetado, será novamente apreciado pelo Poder Legislativo e, eventualmente, derrubado o veto, por maioria absoluta dos votos em âmbito federal, a votação ocorre no Congresso Nacional, em sessão conjunta (art. 66, § $4^{\circ}$ ) -, será promulgada a lei.

Transcorrido um processo de tal modo intrincado, é natural que o órgão ou os órgãos responsáveis pela edição do ato normativo tenham efetivo interesse em sua manutenção no ordenamento jurídico.

Não é outra a situação dos diversos grupos sociais que tinham algum interesse na aprovação ou não da lei, motivo pelo qual, ao condensar anseios de parcelas significativas da população, a comunidade pode se mostrar interessada na manutenção ou supressão da lei do ordenamento jurídico e, inclusive, pretender manifestar sua posição perante o órgão encarregado de verificar a validade da norma.

Portanto, me parece que a produção de teses distintas a embasar tanto a constitucionalidade como a inconstitucionalidade de determinado ato normativo é perfeitamente possível. 
Havendo órgãos interessados e constitucionalmente legitimados a tanto, não seria imperativa a sua oitiva, sob pena de inconstitucionalidade, por violação ao princípio do contraditório? É indiferente o fato de serem ou não partes, bem como de não possuírem direito subjetivo. Na verdade, se possuem interesses distintos, na manutenção ou retirada da norma do ordenamento jurídico, podem, em tese, contribuir para um melhor esclarecimento da questão colocada à apreciação do tribunal, podendo, assim, contribuir para a qualificação da decisão final e, por via de consequência, para a sua legitimidade. Tudo leva a crer, portanto, que deveriam os interessados, processualmente legitimados, justamente por isso, ser ouvidos no processo de controle abstrato, pois esta me parece ser a melhor maneira de conferir legitimidade à decisão a ser proferida no seu seio.

Ostenta opinião semelhante JULIANO TAVEIRA BERNARDES, para quem:

“da circunstância de os figurantes processuais partilharem do comum interesse de proteção da ordem jurídica não decorre, necessariamente, o raciocínio de que não desejam ou não possam manifestar reação contra a tese defendida pelo lado oposto da relação processual ou contra algum ato praticado no curso do processo". ${ }^{395}$

Esclarece, então, que o contraditório, no controle abstrato, caracterizar-se-ia como mera possibilidade de haver dialética (conflito entre teses diversas) na discussão do tema constitucional, consubstanciada na possibilidade de potencial pluralização de teses sobre a matéria examinada. ${ }^{396}$

Dessa forma, não me parece correto afirmar que os processos de controle de constitucionalidade, ainda que por via principal, sejam absolutamente abstratos. Como bem pondera ANDRÉ RAMOS TAVARES:

395 BERnARDES, Juliano Taveira. Controle Abstrato de Constitucionalidade: Elementos materiais e princípios processuais. São Paulo, Saraiva, 2004, p. 294.

${ }^{396}$ Ibidem, p. 297. 
"Em diversos segmentos próprios do processo objetivo encontram-se presentes elementos de conexão subjetiva ou concreta. Algumas funções como a arbitral, irão oferecer uma solução para solucionar dois interesses contrários, ainda que se trate de interesses institucionais.

Um 'poder' terá interesse em assegurar sua competência legislativa em face de um outro centro de emanação de leis (especialmente nos estados federativos). Só são interesses objetivos no sentido de não se referirem a interesses de sujeitos particulares. Mas a presença de interesses conflitantes é inquestionável, até porque forma a base da atribuição de boa parte da competência da Justiça Constitucional. Se não houvesse interesses em conflito, não haveria necessidade da atuação arbitral do Tribunal Constitucional. É no desempenho dessa função que se verifica enfaticamente a presença de interesses.

Ademais, em todas as funções o Tribunal Constitucional é responsável por fazer atuar, em última instância, a vontade constitucionalmente objetivada. É nesse sentido, pois, que se deve compreender a expressão 'processo objetivo’.”397

Por outro lado, o exercício do poder em um Estado Democrático de Direito (CF, art. $1^{\circ}$ ) pressupõe sempre a oportunidade de participação prévia dos atingidos pelos efeitos da decisão, pois é da participação dos destinatários que se extrai a força vinculante da decisão, como bem elucida DINAMARCO:

“A participação a ser franqueada aos litigantes é uma expressão da idéia, plantada na ordem política, de que o exercício do poder só se legitima quando preparado por atos idôneos segundo a Constituição e a lei, com a participação dos sujeitos interessados. Tem-se por ponto de partida a essencial distinção entre atos de poder, que atingirão a esfera jurídica de pessoas diferentes de quem os realiza; e atos de vontade, ou negócios jurídicos, que se destinam a autoregulação de interesses e são realizados pelos próprios titulares destes (autonomia da vontade). A força vinculante dos negócios jurídicos tem origem e legitimidade na vontade livremente manifestada. Aqueles, na participação dos destinatários segundo as regras pertinentes." 398

BEDAQUE não só demonstra a elevada importância do contraditório, como afirma que, através dele, permite-se aplicar a ideia de processo a outras

\footnotetext{
397 TAVARES, André Ramos. Teoria da Justiça Constitucional, São Paulo, Saraiva, 2005, p. 399-400 (grifos nossos).

${ }^{398}$ DINAMARCO, Cândido Rangel. Instituições de direito processual civil, v. I, São Paulo, Malheiros, $6^{a}$ ed., 2009, p. 220.
} 
atividades não jurisdicionais, das quais resulte um provimento ${ }^{399}$, o que tende a demonstrar a plena aplicabilidade dessa ideia ao processo de controle abstrato de constitucionalidade.

Também nesse sentido, DINAMARCO constata que a "idéia da legitimação pelo procedimento é vitoriosa hoje, mesmo fora do campo jurisdicional, pelo que ela tem de expressivo do ponto-de-vista da inserção do sistema processual na ordem constitucional e da sua aceitabilidade social”. 400

Não se deve esquecer que o exercício da atividade processual, em conformidade com regras pré-estabelecidas, é uma forma de legitimação do exercício do poder. Nesse sentido a tese de NIKLAS LUHMANN, acerca da legitimação pelo procedimento, numa visão sociológica-jurídica. ${ }^{401}$

DINAMARCO vai além, afirmando que a legitimação, em verdade, adviria da observância do contraditório e do devido processo legal, e não apenas do procedimento (enfocando, portanto, o tema sob o ponto de vista jurídico-sociológico):

“Tal é uma derivação da conhecida tese da legitimação pelo procedimento, lançada em sede de sociologia política e de valia em relação a todas as áreas de exercício de poder (Niklas Luhmann). Na realidade, o que legitima os atos de poder não é a mera e formal observância dos procedimentos, mas a participação que mediante o correto cumprimento das normas procedimentais tenha sido possível aos destinatários. Melhor falar, portanto, em legitimação pelo contraditório e pelo devido processo legal." 402

\footnotetext{
399 “A moderna doutrina processual vem desenvolvendo a idéia de que o processo é todo procedimento realizado em contraditório. A legitimidade do provimento resultante do processo depende da efetiva participação das partes na sua formação, ou seja, depende da efetividade do contraditório. Essa concepção tem duas grandes virtudes: realça a importância de um contraditório real, ou seja, da concessão de reais oportunidades às partes de influir no provimento jurisdicional; além disso, permite estender a idéia de processo para toda atividade realizada em contraditório, da qual resulte um provimento, o que não ocorre apenas na esfera jurisdicional.” In: BEDAQUE, José Roberto dos Santos. Poderes instrutórios do juiz. $4^{a}$ ed., São Paulo, Revista dos Tribunais, 2009, p. 66.

${ }^{400}$ DINAMARCO, Cândido Rangel. A instrumentalidade do processo. $13^{\mathrm{a}}$ ed., São Paulo, Malheiros, 2008, p. 155.

${ }^{401}$ LUHMANN, Niklas. Legitimação pelo Procedimento. Brasília, Editora Universidade de Brasília, 1980.

${ }^{402}$ DINAMARCO, Cândido Rangel. Instituições de direito processual civil, v. I. São Paulo, Malheiros, $6^{a}$ edição, 2009, p. 220-221.
} 
Ora, se mesmo fora do campo jurisdicional a tomada de decisões se legitima através do exercício de um procedimento iluminado pelo contraditório, estaria o processo de controle principal de constitucionalidade, processo de natureza jurisdicional, como visto, imune aos efeitos desse princípio constitucional?

A ausência do contraditório no controle abstrato de constitucionalidade não se sustenta sob nenhum aspecto, sequer para aqueles que não veem nele um processo jurisdicional, pois "seria arbitrário o poder exercido sem a participação dos próprios interessados diretos no resultado do processo". ${ }^{403}$ Tratando-se de controle abstrato, interessados são todos aqueles que poderão sofrer os efeitos da decisão, cuja participação deve ser facultada, ainda que através de entidades associativas ou de representação da categoria.

O contraditório, em verdade, é mais que um mero princípio processual. Como evidencia DINAMARCO, ele é a garantia da participação, que não se restringe ao processo jurisdicional, mas constitui característica inseparável do próprio regime democrático:

“Essa participação constitui postulado inafastável da democracia e o processo é em si mesmo democrático e portanto participativo, sob pena de não ser legítimo.”404

Realmente, a ausência de possibilidade de participação nos processos de controle abstrato afrontaria não só o princípio constitucional do contraditório (CF, art. 5 $\left.5^{\circ} \mathrm{LV}\right)$, como o próprio princípio democrático (CF, art. $1^{\circ}$, parágrafo único).

Mas seria necessária a abertura à participação em todo e qualquer procedimento? A resposta é inegavelmente negativa, pois só se faz necessária a abertura à participação dos interessados nos procedimentos voltados à preparação de algum provimento, como expõe, com clareza, DINAMARCO:

\footnotetext{
${ }^{403}$ DINAMARCO, Cândido Rangel. A instrumentalidade do processo. $13^{\mathrm{a}}$ ed., São Paulo, Malheiros, 2008, p. 155-156.

${ }^{404}$ Ibidem, p. 156.
} 
"Por outro lado, a exigência de contraditório constitui conseqüência de tratar-se de procedimentos celebrados em preparação a algum provimento, qualquer que seja a natureza deste: provimento é ato de poder, imperativo por natureza e destinação, donde a necessária legitimação mediante procedimento participativo.”405

Pois, valendo-me ainda da lição do ilustre professor titular das

Arcadas:

"Não se compatibiliza com o espírito do Estado-de-direito democrático a imposição de provimentos sem prévia preparação mediante um procedimento e sem que o procedimento preparador se desenvolva em contraditório; ou seja, não se compatibiliza com ele a emissão de provimentos sem a realização do processo adequado. Onde o exercício do poder não conduz a decisões que sob a forma de provimentos interfiram na esfera jurídica de pessoas, a ordem social e política tolera os procedimentos sem contraditório."

É inegável que, no processo de controle abstrato de constitucionalidade, o tribunal constitucional emite um provimento. E se trata de provimento dotado de eficácia erga omnes e efeitos vinculantes aos demais órgãos do Poder Judiciário e da Administração pública federal, estadual e municipal (Lei federal no 9.868/99, art. 28, parágrafo único). Indubitável, portanto, que da decisão proferida no controle abstrato emana um provimento de elevada autoridade.

Portanto, não se pode conceber, em um Estado democrático de Direito a realização de processo de controle de constitucionalidade sem a observância do princípio do contraditório.

Na Alemanha, País onde se admite tranquilamente o caráter objetivo do controle abstrato, PETER HÄBERLE defende uma ampla participação de cidadãos, grupos sociais, órgãos do Estado e da opinião pública em geral em seu seio, pois, segundo sustenta, todos eles seriam guardiões da Constituição, sendo necessária a formação de uma sociedade aberta de seus intérpretes. Como bem pontua o autor germânico:

${ }^{405}$ DINAMARCO, Cândido Rangel. A instrumentalidade do processo. $13^{\mathrm{a}}$ ed., São Paulo, Malheiros, 2008, p. 157.

${ }^{406}$ Ibidem, p. 157 e 158. 
"Uma Constituição que estrutura não apenas o Estado em sentido estrito, mas também a própria esfera pública (Öffentlichkeit), dispondo sobre a organização da própria sociedade e, diretamente, sobre os setores da vida privada, não pode tratar as forças sociais e privadas como meros objetos. Ela deve integrá-las ativamente enquanto sujeitos.”407

Citando as virtudes da teoria de HÄBERLE, GILMAR FERREIRA MENDES vê no reconhecimento da pluralidade de intérpretes e da complexidade da interpretação constitucional "não apenas uma concretização do princípio democrático, mas também uma consequiência metodológica da abertura material da Constituição”. 408

Ao analisar o sistema de controle português, CARLOS BLANCO DE MORAIS sustenta que o suposto caráter não contraditório dos processos de fiscalização abstrata encontrar-se-ia "na circunstância de o Tribunal Constitucional poder decidir a questão de constitucionalidade ou legalidade suscitada, mesmo que o autor da norma tenha decidido não se pronunciar, não decorrendo efeitos processuais no caso de não pronúncia”. 409

Todavia, é necessário que se tenha em vista que a garantia do contraditório se satisfaz com a ciência bilateral dos atos e termos do processo e possibilidade de reação. Não é necessário que a parte efetivamente se manifeste para que se veja atendido o contraditório. É preciso apenas que tenha sido dada a ela oportunidade de reação.

Pondera, por outro lado, o autor português, que esse caráter não contraditório não impediria o princípio do contraditório de iluminar alguns dos aspectos do procedimento:

\footnotetext{
${ }^{407}$ HÄBERLE, Peter. Hermenêutica Constitucional: A sociedade aberta dos intérpretes da Constituição: contribuição para a interpretação pluralista e procedimental da Constituição., tradução Gilmar Ferreira Mendes, Porto Alegre, Sérgio A. Fabris Editor, 1997, p. 33.

${ }^{408}$ MENDES, Gilmar Ferreira. Direitos fundamentais e controle de constitucionalidade. $3^{\mathrm{a}}$ ed., São Paulo, Saraiva, 2006, p. 466.

${ }^{409}$ MORAIS, Carlos Blanco de. Justiça constitucional, t. II. Coimbra, Coimbra Editora, 2005, p. 536.
} 
"Mas essa natureza não contraditória dos processos não preclude o facto de o princípio do contraditório iluminar, com efectividade, alguns dos estádios processuais. E, na realidade, encontramo-nos no art. $54^{\circ}$. da LTC perante uma projecção do 'princípio do contraditório', princípio que supõe um equilíbrio relativo entre os 'poderes' dos sujeitos aos quais é reconhecida intervenção processual, ainda que colocados em posições opostas, no quadro da tutela do interesse público.”,410

E conclui, afirmando que o princípio do contraditório:

"[apesar do] facto de não se destinar a salvaguardar uma 'igualdade de armas' entre as partes (já que em sentido próprio não existem 'partes' em processos de fiscalização abstrata), procura, ainda assim, garantir: i) Num plano primário, um 'poder' processual de 'réplica' do órgão que emitiu o acto impugnado, que lhe permita defender no plano do Direito, a validade deste último, contra o 'poder' de impugnação exercido pelo órgão autor do pedido, apresentando as razões susceptíveis de fundamentar a sua conformidade com a Constituição ou com a legislação reforçada, faculdade que compreende a adição de um argumentário crítico face ao conteúdo do pedido e da causa de pedir; ii) Num plano secundário ou instrumental, a recolha de elementos e argumentos relevantes, susceptíveis de facilitarem a actividade instrutória do juiz relator." ${ }^{411}$

Assim, ainda que não se considere o controle abstrato de constitucionalidade um processo contraditório por natureza, há de se reconhecer que o princípio do contraditório é perfeitamente aplicável em seu âmbito, desde que observadas as peculiariedades que o caracterizam e diferenciam-no das demais espécies de processo de índole subjetiva.

Sob outro ponto de vista, a invocar a visão procedimental da democracia, sustentada por HABERMAS, ÁLVARO RICARDO DE SOUZA CRUZ pondera que:

"Restou claro que para Habermas (1997) é do próprio procedimento
democrático (e não por princípios materiais) que o Direito extrai sua
legitimidade das sociedades contemporâneas. Assim, torna-se indispensável
tratar o controle da constitucionalidade das leis dentro do contexto da
realização de um consenso racional, fruto da ação comunicativa. Contudo, a

${ }^{410}$ MORAIS, Carlos Blanco de. Justiça constitucional, t. II. Coimbra, Coimbra Editora, 2005, p. 536.

${ }^{411}$ Ibidem, p. 536-537. 
procura pelo melhor (mais adequado) argumento exige uma perspectiva dialética nesse procedimento, que só se pode dar pela implementação do contraditório." ${ }^{412}$

Em crítica à própria visão objetiva do processo de controle abstrato, assevera que só poderiam ser aceitas as normas jurídicas cujos destinatários participem de sua elaboração, fazendo-se necessário, assim, o debate argumentativo e dialético que decorre do contraditório:

\begin{abstract}
"Garantir um fluxo comunicativo de idéias implica aceitar a oposição, percebendo que o debate é essencial na busca de melhores soluções para a ação, tanto do Estado quanto da sociedade. Assim, o processo é necessariamente um procedimento subjetivo, sujeito ao devido processo legal, contraditório e ampla defesa (art. $5^{\circ}$, LV da CF/88), sem o que perde sua legitimidade democrática. Logo, não deve ser visto como um 'processo objetivo' e distinto dos procedimentos da legislação ordinária, tal como argumentam o próprio Supremo e o constitucionalismo comunitarista." ${ }^{413}$
\end{abstract}

A censura à caracterização do controle abstrato de normas como processo objetivo me parece um tanto quanto exagerada e, com a devida vênia, indevida. Entendo que sequer seja necessário subtrair a concepção objetiva do controle abstrato para perceber que a abertura à manifestação por parte do maior número de órgãos ou entidades mostra-se imprescindível ao exercício do controle abstrato.

A argumentação dialética e o contraditório são, na realidade, elementos de todo e qualquer processo. JOSÉ AFONSO DA SILVA, ao comentar o processo legislativo de aprovação das leis, valendo-se dos ensinamentos de HEGEL, ressalta que toda “transformação fenomenológica realiza-se através de um processo, cujo conteúdo compreende aspectos contraditórios, oposição de interesses divergentes”. ${ }^{414}$ E acrescenta, invocando, agora, COUTURE, que:

\footnotetext{
${ }^{412}$ CRUZ, Álvaro Ricardo de Souza. Jurisdição constitucional democrática. Belo Horizonte, Del Rey, 2004, p. 370.

${ }^{413}$ Ibidem, p. 371.

${ }^{414}$ SILVA, José Afonso da. Processo constitucional de formação das leis. $2^{\mathrm{a}}$ ed., São Paulo, Malheiros, 2007, p. 40.
} 
“'O processo é, em si mesmo, um método de debate’. E na mesma ordem de idéias, complementa: ' $O$ debate por si mesmo, entretanto, não tem sentido. O processo, se tem uma estrutura dialética, é porque graças a ela se procura a obtenção de um fim. Toda idéia de processo é essencialmente teleológica, visto que aponta para u'a meta de chegada'.,415

O debate argumentativo volta-se, ainda, a suprir uma deficiência do processo de controle abstrato, decorrente do fato de o tribunal constitucional ter de examinar a questão originariamente e, por vezes, com exclusividade. ${ }^{416}$ No modelo difuso e incidental, a questão constitucional chega ao tribunal de cúpula do Judiciário por meio de recursos, tendo sido objeto de diversas decisões em instâncias inferiores, nas quais certamente foram debatidas as diversas perspectivas e questões envolvendo a matéria, que servem de substrato à decisão da Suprema Corte.

Já no controle principal, a inconstitucionalidade é submetida diretamente à corte ou tribunal constitucional, inexistindo, necessariamente, um debate prévio sobre a matéria, o que dificulta a percepção do tema sob diversos matizes pelos componentes daquele colegiado. Daí a importância de se possibilitar a manifestação do maior número de interessados, de modo que exponham o seu ponto de vista sobre a matéria e permitam aos membros da corte a melhor compreensão da questão, sob as diversas facetas que a matéria envolve.

\footnotetext{
${ }^{415}$ SILVA, José Afonso da. Processo constitucional de formação das leis. $2^{\mathrm{a}}$ ed., São Paulo, Malheiros, 2007, p. 40.

${ }^{416}$ De fato, assevera BARACHO, ao analisar as diferenças entre o modelo americano e o europeu de controle de constitucionalidade: "O contencioso constitucional apresenta particularidades que o distinguiu de outros contenciosos. No controle difuso de constitucionalidade, os tribunais são chamados a se pronunciar sobre todos os aspectos de um mesmo litígio, sem que se possa distinguir entre questões civis, administrativas ou constitucionais: os tribunais americanos têm plenitude de jurisdição.

Ao passo que os tribunais europeus são obrigados a fazer a seleção das questões postas e eventualmente colocadas, no que se refere à constitucionalidade de uma lei, na qual a aplicação condiciona a solução do litígio.

As questões de inconstitucionalidade da lei constituem, elas próprias, um contencioso cujo julgamento é atribuído, de maneira exclusiva, à Corte Constitucional.

É um monopólio que concentra em suas mãos o poder de interpretar a Constituição. As vantagens dessa ‘concentração’ são evidentes: a unidade de interpretação reforça a coesão dessas decisões, reduz as ilegalidades e assegura a segurança jurídica. A corte suprema, no sistema americano, age da mesma maneira; deve harmonizar ou sintetizar várias interpretações decorrentes das decisões contraditórias, emanadas dos juízes inferiores.” In: BARACHO, José Alfredo de Oliveira. Direito Processual Constitucional: aspectos contemporâneos. Belo Horizonte, Editora Fórum, 2006, p. 29-30.
} 
Quanto mais ampla for a possibilidade de participação na formulação de teses e antíteses acerca da constitucionalidade da lei ou ato normativo, no seio do controle abstrato, melhor será a decisão e, igualmente, dotada de maior legitimidade.

Como se pode desde logo perceber, o debate argumentativo acerca da adequação constitucional da norma, mediante abertura do processo à intervenção plural de interessados, é perfeitamente possível nas ações diretas de controle de constitucionalidade.

Além do mais, a abertura do processo à manifestação dos órgãos responsáveis pela edição do ato normativo, bem como de entidades juridicamente interessadas em se manifestar no processo (desde que legitimadas para tanto e devidamente comprovado o seu interesse jurídico) revela-se, em meu sentir, além de absolutamente apropriada, imprescindível à legitimação e qualificação da decisão final. Ao comentar a proposta de KELSEN acerca da participação dos legitimados no processo de controle abstrato, ROGER STIEFELMANN LEAL, ressalta o equívoco que constitui defender a ausência de contraditório naquela espécie de processo:

"O processo realizado em sede de jurisdição constitucional abstrata, em virtude de discutir a constitucionalidade em tese de um ato normativo, afeta o interesse de muitas pessoas, sendo, assim, inviável a participação de todos os interessados. Tal limitação, porém, não deve ser confundida com ausência de contraditório. Falar em processo sem partes e sem contraditório constitui, no modelo apresentado por Kelsen, um equívoco."417

Ainda que se entenda ser objetiva a verificação de adequação à Constituição, a manifestação de diversos interessados na manutenção, ou na invalidação, da lei ou ato normativo tende a humanizar o processo, revelando, inclusive, em decorrência dos efeitos da decisão, eventuais malefícios ou benefícios decorrentes da sua prolatação, além de outras consequências que nem sempre podem estar presentes na mente dos julgadores, pois

${ }^{417}$ LEAL, Roger Stiefelmann. O efeito vinculante na jurisdição constitucional. São Paulo, Saraiva, 2006, p. 49. 
eles, embora dotados de notável saber jurídico (C.F., art. 101), não são, evidentemente, oniscientes.

É certo que algumas previsões constitucionais e legais favorecem a incidência do referido princípio processual na ação direta de inconstitucionalidade como, v.g., a previsão de citação do Advogado Geral da União (CF, art. 103, $\S 3^{\circ}$ ), ou do Procurador Geral do Estado (CESP, art. 90, $\S 2^{\circ}$ ), em caso de controle estadual, com vistas à defesa do ato ou texto impugnado.

No mesmo sentido, a autorização conferida ao relator para, considerando a relevância da matéria e a representatividade dos postulantes, admitir manifestações de órgãos ou entidades (Lei $n^{\circ}$ 9.868/99, art. 7, § $2^{\circ}$ ) ou, ainda, para requisitar informações adicionais, designar perito ou comissão de peritos, ouvir depoimento de pessoas etc (Lei $n^{\circ} 9.868 / 99$, art. $9^{\circ}$, $\S \S 1^{\circ}, 2^{\circ}$ e $3^{\circ}$; Lei ${ }^{\circ} 9.882 / 99$, art. $5^{\circ}$, $\S 2^{\circ}$ ).

Também a figura do amicus curiae tende a contribuir para a abertura do contraditório no controle abstrato de constitucionalidade. Todavia, embora haja previsão expressa de sua intervenção na declaratória de inconstitucionalidade (art. $7^{\circ}$, § $1^{\circ}$ ) e na arguição de descumprimento de preceito fundamental (art. $6^{\circ}, \S 2^{\circ}$ ), semelhante permissivo, em relação à ação declaratória de constitucionalidade, sofreu veto do Poder Executivo (§ $1^{\circ}$ do art. 18).

Seria constitucional a vedação de participação do amicus na declaratória de constitucionalidade? Diante de uma visão de interpretação pluralista e aberta da Constituição, que respeite a essência do Estado democrático de Direito, parece-me que não. Deve haver uma necessária abertura, também na ação declaratória de constitucionalidade, para a participação de terceiros interessados, desde que atendam os requisitos exigidos para a participação previstos na ação direta de inconstitucionalidade e na arguição de descumprimento de preceito fundamental, para que possam ali atuar na qualidade de amicus curiae. 
Para aqueles que entendem que a ação declaratória de constitucionalidade e a ação direta de inconstitucionalidade são ações de caráter dúplice, concepção referendada pelo $\mathrm{STF}^{418}$, a observância do contraditório seria uma decorrência lógica, pois se tanto uma como outra ação podem levar ao reconhecimento da inconstitucionalidade ou da constitucionalidade da norma, deverá, igualmente, haver identidade no procedimento de ambas em tudo o que não contrarie a essência dessas ações. E a observância do contraditório na ação declaratória de constitucionalidade, mediante a abertura do procedimento à participação de interessados, longe de contrariar a sua natureza, atende às exigências de participação do Estado democrático de Direito e contribui sensivelmente para qualificar o seu resultado.

Todavia, como mencionado acima, a configuração normativa atual não permite que se entenda que a ação direta de inconstitucionalidade e a ação declaratória de constitucionalidade são ações de caráter dúplice, mas, inegavelmente, possuem a mesma natureza, o que permite a aplicação em ambas do princípio do contraditório.

É esse, portanto, o sentido que me parece deva assumir o contraditório no controle abstrato de normas: instaurado com a finalidade de permitir a participação pluralista e democrática dos entes juridicamente legitimados, com vistas a qualificar e conferir legitimidade às decisões da corte constitucional ou tribunal que exerça suas funções, como é o caso do Supremo Tribunal Federal.

A jurisprudência do Supremo Tribunal Federal tem evoluído na vertente de admitir a existência do contraditório nos processos objetivos. Em julgado já não tão recente daquele Tribunal, no qual foi confirmada a impossibilidade de participação de terceiros no processo objetivo (ressaltando-se que se trata de decisão anterior às Leis 9.868/99 e 9.882/99, que vieram a prever a possibilidade de participação do amicus curiae), no voto proferido pelo Ministro CELSO DE MELLO há menção expressa à forma pela qual se vê respeitado o postulado do contraditório nos processos objetivos:

${ }^{418}$ Vide nota ${ }^{\circ} 274$, supra. 
"O postulado do contraditório, no processo de controle abstrato de constitucionalidade vê-se atendido, de um lado, com a possibilidade de o órgão estatal defender, objetivamente, o próprio ato que editou, e, de outro, com a intervenção do Advogado-Geral da União, que, em atuação processual plenamente vinculada, deve assumir, na condição de garante e curador da presunção de constitucionalidade, a defesa irrestrita da validade jurídica da norma impugnada."

Em outra oportunidade, já em momento mais recente, o Ministro FERREIRA MENDES enfoca a conveniência da ampliação do direito de manifestação de diferentes órgãos e entidades no processo de controle de normas, bem como da ampla investigação probatória, quando necessária:

“Em verdade, a moderna doutrina constitucional defende abertamente não só a ampliação do direito de manifestação de diferentes órgãos ou entidades no processo de controle de normas, mas também a ampla investigação probatória, quando necessária, reconhecendo, assim, que "o círculo de interessados e de intérpretes do Direito Constitucional é mais pluralista do que aquele de outras codificações (Der Interessenter und Interpretenkreis des Verfassungsrechts ist pluralistischer als derjenige anderer Kodifikationen).,"420

Portanto, à guisa de conclusão, entendo que o princípio do contraditório é plenamente aplicável no âmbito do controle abstrato de constitucionalidade, desde que observadas as características próprias desta espécie de processo.

Como referido anteriormente, não se pode conceber, em um Estado democrático de Direito, a realização de processo de controle de constitucionalidade sem a observância do princípio do contraditório. Este princípio é inerente à própria democracia, cuja essência exige, para a prolatação de uma decisão que venha a intervir na esfera de indivíduos (um provimento), que seja ela precedida do contraditório, isto é, da oportunidade de os interessados apresentarem seus argumentos com a finalidade de influir no resultado do julgamento.

419 ADI-MC 1434/SP. Relator Ministro CELSO DE MELLO. Julgamento: 20/08/1996, Tribunal Pleno, publicação: DJ 22/11/1996, p. 45684. Ement. vol. 01851-01, p. 0141.

${ }_{420}$ ADI 2982-ED/CE, Relator Ministro GILMAR FERREIRA MENDES. Julgamento: 02/08/2006, Órgão Julgador: Tribunal Pleno. Publicação: DJ 22-09-2006, p. 029. Ement. vol. 02248-01, p. 0171. LEXSTF, v. 28, nº 335, 2006, pp. 53-59. 
Revela-se, portanto, inseparável do controle abstrato de constitucionalidade o debate pluralista voltado a legitimar e qualificar a decisão a ser aí proferida.

\subsubsection{A manifestação do Advogado-Geral da União}

Preceitua o parágrafo $3^{\circ}$ do artigo 103 que, quando o Supremo Tribunal Federal apreciar a inconstitucionalidade em tese de lei ou ato normativo, citará o Advogado-Geral da União, que defenderá o ato ou texto impugnado.

O caráter cogente da norma está evidente em sua própria redação, que não deixa espaço para dúvidas, quanto à necessidade da apresentação de defesa do ato impugnado pelo AGU.

A defesa da constitucionalidade da norma por parte do AGU foi, inicialmente, ressaltada pelo STF, que assentou ser aquele um munus indisponível. Nesse sentido, veja-se, a título ilustrativo, o teor da decisão proferida na ADI 97, relatada pelo Ministro MOREIRA ALVES, cuja ementa possui o seguinte teor:

"AÇÃO DIRETA DE INCONSTITUCIONALIDADE. COMPETÊNCIA DO ADVOGADO-GERAL DA UNIÃO. EXEGESE DO PARÁGRAFO 3 DO ARTIGO 103 DA CONSTITUIÇÃO. - COMPETE AO ADVOGADO-GERAL DA UNIÃO, EM AÇÃO DIRETA DE INCONSTITUCIONALIDADE, A DEFESA DA NORMA LEGAL OU ATO NORMATIVO IMPUGNADO, INDEPENDENTEMENTE DE SUA NATUREZA FEDERAL OU ESTADUAL. NÃO EXISTE CONTRADIÇÃO ENTRE O EXERCÍCIO DA FUNÇÃO NORMAL DO ADVOGADO DA UNIÃO, FIXADA NO CAPUT DO ARTIGO 131 DA CARTA MAGNA, E O DA DEFESA DE NORMA OU ATO INQUINADO, EM TESE, COMO INCONSTITUCIONAL, QUANDO FUNCIONA COMO CURADOR ESPECIAL, POR CAUSA DO PRINCÍPIO DA PRESUNÇÃO DE SUA CONSTITUCIONALIDADE. QUESTÃO DE ORDEM QUE SE DECIDE NO SENTIDO DA DEVOLUÇÃO DOS AUTOS A 


\section{PROCURADORIA-GERAL DA REPUBLICA, PARA QUE APRESENTE A DEFESA DAS NORMAS ESTADUAIS IMPUGNADAS.” ${ }^{421}$}

A concepção do legislador constituinte não esteve alheia a críticas. O Advogado-Geral da União é cargo de livre nomeação pelo Presidente da República, não sendo sequer necessário que pertença à carreira da Advocacia Geral da União (CF, art. 131, § $1^{\circ}$ ). Dessa forma, tendo como função a defesa dos interesses da União e, particularmente, do Poder Executivo, não é a pessoa mais indicada para defender a constitucionalidade da lei, que pode, como sói acontecer, ter a sua inconstitucionalidade arguida pelo próprio Presidente da República, que, aliás, figura em primeiro lugar no rol de legitimados para a propositura de ação direta de inconstitucionalidade (CF, art. 103, I). ${ }^{422}$

Posteriormente, como nos informam GANDRA MARTINS e FERREIRA MENDES, o STF alterou sua orientação tradicional, passando a admitir a possibilidade de isenção da Advocacia-Geral da União em face da defesa da tese jurídica da inconstitucionalidade do diploma normativo impugnado, desde que já tivesse havido precedente daquela Corte acerca da matéria tratada na nova ação direta de inconstitucionalidade. ${ }^{423}$

\footnotetext{
${ }^{421}$ ADI 97 QO/RO. Relator: Min. MOREIRA ALVES. Julgamento: 22/11/1989. Órgão Julgador: Tribunal Pleno. Publicação: DJ 30-03-1990, p. 02339. Ement. vol. 01575-01, p. 01. RTJ Vol. 0131-02, p. 0470.

${ }^{422}$ Essa contradição foi amplamente notada, citando-se, a título exemplificativo, o abalizado entendimento de IVES GANDRA DA SILVA MARTINS e de GILMAR FERREIRA MENDES: "No caso do disposto no art. 103 , $\S 3^{\circ}$, é difícil imaginar o que pretendeu, de fato, o constituinte, ao designar um órgão da consultoria jurídica do Poder Executivo federal para proceder à defesa de atos dos demais Poderes federais, bem como dos atos normativos editados pelos Estados-Membros. Se, efetivamente, pretendia criar aqui um autêntico processo contraditório, tem-se de reconhecer que não logrou concretizar o seu intento. Basta considerar que o Presidente da República é um dos órgãos legitimados a provocar o Supremo Tribunal Federal, no controle abstrato de normas (art. 103, I). E ao Advogado-Geral da União, nos expressos termos do art. 131, caput, incumbe prestar consultoria e assessoria jurídica ao Poder Executivo federal. Assim, como poderá o Advogado-Geral da União defender o ato impugnado, quando se tratar de argüição feita pelo próprio Chefe do Executivo (art. 103, I)? Nesse caso, ter-se-ia a seguinte situação: enquanto consultor jurídico do Presidente da República (art. 131, caput), caberia ao Advogado-Geral da União desenvolver argumentos e formular pareceres que demonstrassem a inconstitucionalidade da lei a ser impugnada diretamente perante o Supremo Tribunal Federal. Nos termos doa art. 103, $\S 3^{\circ}$, deveria defender o ato que, enquanto assessor jurídico, acabou de impugnar. ... Caberia indagar ainda se o Advogado-Geral da União deveria defender ato manifestamente inconstitucional. Em princípio não se pode exigir que órgão instituído pela Constituição veja-se na contingência de propugnar pela legitimidade de atos contrários ao ordenamento básico, em flagrante ofensa ao postulado imanente da fidelidade constitucional. [...].” In: MARTINS, Ives Gandra da Silva; MENDES, Gilmar Ferreira. Controle concentrado de constitucionalidade: Comentários à Lei n. 9.868, de 10-11-1999. $3^{\text {a }}$ ed., São Paulo, Saraiva, 2009, p. 290-291.

${ }^{423}$ Ibidem, p. 293-294.
} 
Nesse sentido, na ADI 1616, relatada pelo Min. MAURÍCIO

CORREA, decidiu a Corte Suprema o seguinte:

“O munus a que se refere o imperativo constitucional (CF, artigo 103, $\S 3^{\circ}$ ) deve ser entendido com temperamentos. O Advogado- Geral da União não está obrigado a defender tese jurídica se sobre ela esta Corte já fixou entendimento pela sua inconstitucionalidade.”424

Por fim, em recentíssimo julgado, o STF revisou seu entendimento tradicional, passando a reconhecer como não obrigatória a defesa da lei pelo Advogado-Geral da União.

De fato, na ADI 3916 foi suscitada questão de ordem pelo Ministro MARCO AURÉLIO, no sentido de suspender o julgamento da ação para o fim de determinar que o Advogado-Geral da União apresentasse defesa da lei impugnada, nos termos do artigo 103, § $3^{\circ}$ da Constituição federal. O Tribunal, por maioria, vencidos os Ministros MARCO AURÉLIO e JOAQUIM BARBOSA, rejeitou a questão de ordem, tendo entendido que o AGU poderia se manifestar em conformidade com a sua convicção jurídica. ${ }^{425}$

${ }^{424}$ ADI 1616/PE. Relator: Min. MAURÍCIO CORRÊA. Julgamento: 24/05/2001. Órgão Julgador: Tribunal Pleno. Publicação. DJ: 24-08-2001, p.041. Ement. vol. 02040-02, p. 0303.

425 “O Tribunal, por maioria, rejeitou a questão de ordem no sentido de suspender o julgamento para determinar ao Advogado-Geral da União que apresente defesa da lei impugnada, nos termos do artigo 103 , § $3^{\circ}$, da Constituição Federal, vencidos os Senhores Ministros Marco Aurélio (suscitante) e Joaquim Barbosa. Votou o Presidente. Em seguida, após o voto do Senhor Ministro Eros Grau (Relator), julgando improcedente a ação, os votos dos Senhores Ministros Cármen Lúcia e Cezar Peluso, julgando parcialmente procedente a ação para declarar a inconstitucionalidade do artigo 13, caput, da Lei Distrital n ${ }^{\circ}$ 3.669, de 13 de setembro de 2005, e os votos dos Senhores Ministros Ricardo Lewandowski, Joaquim Barbosa e Carlos Britto, julgando totalmente procedente a ação, pediu vista dos autos a Senhora Ministra Ellen Gracie. Ausente, justificadamente, o Senhor Ministro Celso de Mello. Presidência do Senhor Ministro Gilmar Mendes. Plenário, 07.10.2009.” DJ de 19/10/2009. Vide, outrosssim, o texto publicado nas "Notícias STF", do dia 07 de outubro de 2009, com o seguinte título: "Em análise de ADI sobre a carreira da Polícia Civil, Supremo entende não ser obrigatória defesa da lei pela AGU” Disponível em: < http://www.jusbrasil.com.br/noticias/1955250/em-analise-de-adi-sobrecarreira-da-policia-civil-supremo-entende-nao-ser-obrigatoria-defesa-de-lei-pela-agu> Acesso em 10.10.2009. 


\subsubsection{A defesa da constitucionalidade da lei ou do ato normativo pelo Parlamento}

Como se pode observar, a opção de atribuir ao Advogado-Geral da União o dever de realizar a defesa da constitucionalidade da lei não é apropriada e acaba de ser desarticulada pelo próprio STF.

$\mathrm{Na}$ verdade, o órgão consultivo e representativo do Poder Executivo federal não se revela como a melhor alternativa para a defesa da constitucionalidade dos atos normativos cuja constitucionalidade é arguida.

Por outro lado, o órgão que conjuga diversas tendências políticas e que, portanto, teria, em tese, sempre algum grupo convencido da constitucionalidade de determinada lei e interessado em sua defesa é o Poder Legislativo.

Ademais, o parlamento é dirigido por um órgão colegiado (Mesas da Câmara dos Deputados, do Senado e do Congresso, CF, art. 57, §§ $4^{\circ}$ e $5^{\circ}$ ), que por sua própria formação multipartidária tem melhores condições de defender a constitucionalidade das leis aprovadas, pois a defesa de lei ou ato normativo que não seja de interesse do partido de um dos membros da Mesa pode ser interesse de outro. Além disso, a composição política nos parlamentos se faz por meio de apoio de diversos partidos políticos, que poderão solicitar à Mesa Diretora que apresente defesa das leis cujos projetos foram originados de membros de suas bancadas.

Nesse sentido, melhor opção seria atribuir a defesa da lei ou ato normativo às Mesas Diretoras das Casas legislativas (que poderão, efetivamente, fazê-lo nas informações a serem prestadas no processo de controle de constitucionalidade) ou mesmo a 
um órgão jurídico (Procuradoria-Geral) a ser incumbido desta tarefa, tal como ocorre, a título de exemplo, no Estado de Minas Gerais (Constituição estadual, art. 118, § 5 ${ }^{\circ 426}$ ).

Portanto, entendo, de lege ferenda, que a defesa da constitucionalidade das leis e atos normativos deve ser feita por órgão do Poder Legislativo, previamente instituído, no texto constitucional, para esse fim. Poderá, inclusive, haver mais de uma manifestação, como, a título de exemplo, da liderança da maioria e da minoria, ambas expondo sua opinião jurídica acerca da validade constitucional da norma, tudo de modo a alargar o debate acerca da constitucionalidade, incluindo nele as minorias parlamentares, sempre com propósito de democratizá-lo.

\subsubsection{O princípio da irrecorribilidade (Lei federal $n^{0} 9.868 / 99$, art. 26 e Lei federal $\mathbf{n}^{\circ}$}

\subsection{2/99, art. 12)}

Inicialmente, as normas que disciplinavam as ações de controle de constitucionalidade perante o Supremo Tribunal Federal admitiam a interposição de embargos infringentes contra as decisões não unânimes proferidas pelo Plenário no julgamento de ações de controle de constitucionalidade.

Esses embargos eram previstos inicialmente na Lei $n^{\circ} 4.337 / 64$, que disciplinava o procedimento da ação direta interventiva, cujo artigo $6^{\circ}$ exigia o seu cabimento caso houvesse, no mínimo, 3 (três) votos divergentes. ${ }^{427}$

\footnotetext{
${ }^{426}$ Art. 118 - São partes legítimas para propor ação direta de inconstitucionalidade de lei ou ato normativo estadual ou municipal, em face desta Constituição:

[...]

$\S 5^{\circ}$ - Quando o Tribunal de Justiça apreciar a inconstitucionalidade, em tese, de norma legal ou ato normativo estadual, citará, previamente, o Advogado-Geral do Estado e o Procurador-Geral da Assembléia Legislativa, que defenderão o ato ou texto impugnado, ou, no caso de norma legal ou ato normativo municipal, o Prefeito e o Presidente da Câmara Municipal, para a mesma finalidade. (Parágrafo com redação dada pelo art. $4^{\circ}$ da Emenda à Constituição no 56, de 11/7/2003).”.

427 "Art. $6^{\circ}$ Só caberão embargos, que se processarão na forma da legislação em vigor, quando, na decisão, forem 3 (três) ou mais os votos divergentes”.
} 
Com a Constituição de 1967/1969, a matéria passou a ser regulada pelo Regimento Interno do Supremo Tribunal Federal. De fato, como mencionado anteriormente, a Constituição de 1967, com a redação conferida pela EC nº 1, de 1969, conferia ao STF a competência para elaborar seu Regimento Interno e, por meio dele, disciplinar "o processo e julgamento dos feitos de sua competência originária ou de recurso" (art. 120, parágrafo único, “c”, posteriormente modificado pela EC $\mathrm{n}^{\circ} 7 / 77$, que realocou a matéria no $\S 3^{\circ}$, do art. $119^{428}$ ). Atribuiu-se, portanto, ao Supremo Tribunal Federal competência normativa para disciplinar a específica matéria do processo da representação de inconstitucionalidade.

O Regimento Interno do Supremo Tribunal Federal previu, no artigo 333, o cabimento de embargos infringentes contra as decisões não unânimes do Plenário ou da Turma, exigindo a existência de 4 (quatro), e não mais 3 (três), votos divergentes. ${ }^{429}$

Por fim, como lembrado por TAVEIRA BERNARDES, promulgada a Constituição de 1988, foi aprovada a Lei de Recursos (Lei ${ }^{\circ}$ 8.038/90), tendo surgido dúvida quanto à abolição dos embargos infringentes, no entanto, “considerando que a Lei $n^{\circ}$ 8.038/90 em nada alterou a matéria, o STF seguiu admitindo referidos embargos, ensejando assim a possibilidade de dúplice pronunciamento final nas ações diretas.”

A modificação sobreveio apenas com a aprovação das leis que tratam da ação direta de inconstitucionalidade, declaratória de constitucionalidade e de arguição de descumprimento de preceito fundamental. De fato, dispõe o artigo 26 da Lei $n^{\circ}$ 9.868/99, e de maneira análoga o art. 12, da Lei $n^{\circ}$ 9.882/99, que as decisões do Supremo Tribunal Federal que reconhecem a constitucionalidade ou a inconstitucionalidade, em ação

428 “Art. 119. Compete ao Supremo Tribunal Federal: [...]

$\S 3^{\circ} \mathrm{O}$ regimento interno estabelecerá: [...]

c) o processo e julgamento dos feitos de sua competência originária ou recursal e da argüição de relevância da questão federal.”

429 “Art. 333. Cabem embargos infringentes à decisão não unânime do Plenário ou da Turma: [...]

IV - que julgar a representação de inconstitucionalidade; [...]

Parágrafo único. O cabimento dos embargos, em decisão do Plenário, depende da existência, no mínimo, de quatro votos divergentes, salvo nos casos de julgamento criminar em sessão secreta.”

430 TAVEIRA BERNARDES, Juliano. Controle abstrato de constitucionalidade: Elementos materiais e princípios processuais. São Paulo, Saraiva, 2004, p. 466. 
direta ou declaratória, bem como em arguição de descumprimento fundamental são irrecorríveis.

A irrecorribilidade prestigia a segurança jurídica e a estabilidade das relações jurídicas, especialmente tendo-se em vista que a decisão proferida pelo Supremo Tribunal Federal em controle abstrato de constitucionalidade possui efeitos erga omnes e, eventualmente, a natureza de um ato legislativo-negativo. Lembre-se, outrossim, que o ato normativo eivado de vício de inconstitucionalidade usurpa a eficácia da própria Constituição, motivo pelo qual há urgência na sua retirada do ordenamento de modo a restituir a higidez constitucional, tudo a recomendar que a decisão proferida possa surtir desde logo seus efeitos e de maneira perene.

Por outro lado, tendo em vista que é o Plenário do Supremo Tribunal Federal que profere as decisões sobre a constitucionalidade ou inconstitucionalidade de lei, devendo estar presentes para o julgamento ao menos 8 (oito) Ministros ${ }^{431}$, uma vez tomada a decisão não teria sentido submetê-la a um novo julgamento pelo mesmo órgão, que já analisou a questão através de, pelo menos, mais de 2/3 (dois terços) de seus membros, requerendo a declaração de inconstitucionalidade o voto de, ao menos, a maioria absoluta dos Ministros (CF, art. $97^{432}$ ). Não que isso fosse impossível, mas não se mostra racionalmente coerente e sequer prestigia o princípio da celeridade processual. ${ }^{433}$

Eventuais omissões, contradições ou até mesmo equívocos das decisões poderão ser corrigidos por meio de embargos de declaração (Lei federal $n^{0}$ 9.868/99, art. 26 e Lei federal $n^{\circ} 9.882 / 99{ }^{434}$

\footnotetext{
${ }^{431}$ Na mesma linha, a Lei federal n ${ }^{\circ} 9.882 / 99$ possui o seguinte dispositivo: “Art. $8^{\circ}$ A decisão sobre a arguição de descumprimento de preceito fundamental somente será tomada se presentes na sessão pelo menos 2/3 (dois terços) dos Ministros.”

${ }^{432}$ Quanto a este critério, veja-se o princípio do juiz natural, item 3.2.2, supra.

${ }^{433}$ A celeridade do processo ganhou foro constitucional com a EC n ${ }^{\circ} 45 / 2004$ que, em seu art. 5, LXXVIII, dispôs que "a todos, no âmbito judicial e administrativo, são assegurados a razoável duração do processo e os meios que garantam a celeridade de sua tramitação".

${ }^{434}$ Embora não haja previsão expressa de embargos de declaração em face da decisão proferida em arguição de descumprimento de preceito fundamental, entendo que sua oposição neste caso é perfeitamente possível, em face da identidade de natureza entre as ações, por meio de aplicação analógica.
} 
Embora os embargos declaratórios suspendam os prazos processuais, o cumprimento da decisão proferida da ação direta de inconstitucionalidade não é suspenso pela sua oposição. Dessa forma, o cumprimento da decisão pode se dar antes do seu trânsito em julgado. O Supremo Tribunal Federal entende que o sistema processual nacional permite o cumprimento das decisões judiciais antes do julgamento final da lide em razão do poder geral de cautela. ${ }^{435}$

O prazo para interposição de embargos de declaração, por outro lado, inicia-se a partir da publicação da decisão, segundo a regra geral prevista nos arts. 506, III, e 536 do Código de Processo Civil. O Supremo Tribunal Federal proferiu decisão não conhecendo de embargos declaratórios opostos antes da publicação do acórdão, por extemporaneidade, entendendo que, neste caso, o recurso seria desprovido de objeto. ${ }^{436}$

Este fosso entre o início de eficácia da decisão, fixada na Questão de Ordem da ADI 711, contado a partir da publicação no Diário da Justiça da ata da sessão de julgamento, da qual decorre a necessidade de implementação da decisão ${ }^{437}$, e o momento em que se torna viável a oposição de embargos de declaração, que requer a publicação do acórdão, pode trazer em certas complicações práticas (vejam-se os comentários ao princípio da publicidade, item 3.2.11, infra).

De fato, se houver obscuridade, contradição ou omissão no julgado, a decisão teria que ser, ainda assim, cumprida de plano e os embargos voltados à correção dos referidos defeitos só seriam admitidos quando da publicação do acórdão, que pode demorar um lapso considerável de tempo.

\footnotetext{
${ }^{435}$ Reclamação 2576/SC, Relator Ministra ELLEN GRACIE, Tribunal Pleno. Publicação: DJ 20.08.2004, p. 38, ement. vol. 02160-01, p. 105, RTJ vol. 193-01, p. 103.

${ }^{436}$ Embargos de declaração na ação direta de inconstitucionalidade no 2075/RJ, Relator Ministro CELSO DE MELLO, Tribunal Pleno. DJ 27.06.2003. Ement. vol. n ${ }^{\circ}$ 2116-2, cuja ementa possui o seguinte teor: "AÇÃO DIRETA DE INCONSTITUCIONALIDADE - EMBARGOS DE DECLARAÇÃO - EXTEMPORANEIDADE - IMPUGNAÇÃO RECURSAL PREMATURA, EIS QUE DEDUZIDA EM DATA ANTERIOR À DA PUBLICAÇÃO DO ACÓRDÃO CONSUBSTANCIADOR DO JULGAMENTO - RECURSO DESTITUÍDO DE OBJETO - NÃO CONHECIMENTO DOS EMBARGOS DE DECLARAÇÃO.”

437 "O deferimento da medida cautelar produz seus efeitos a partir da data da publicação da ata de julgamento no Diário de Justiça da União.” In: ADI no 711, Relator Ministro NERY DA SILVEIRA. Julgamento: 05/08/1992. Órgão julgador: Tribunal pleno. Publicação: D.J. 11-06-1993, p. 11529; ement. vol. 01707-01, p. 06.
} 
Resta ao interessado a possibilidade de requerer ao relator do feito que suscite uma questão de ordem e leve a questão a Plenário, pois meio recursal outro não há para a correção imediata da decisão na hipótese aventada.

O princípio da irrecorribilidade, excetuada a oposição de embargos de declaração, como visto, aplica-se, por outro lado, apenas às decisões proferidas pelo Plenário do Tribunal. De fato, as decisões monocráticas, tanto as que analisam pedido de medida cautelar, como as que não conhecem da ação, são recorríveis, por meio de agravo regimental (RISTF, art. $317^{438}$ e Lei federal $n^{\circ}$ 9.868/99, art. $4^{\circ}$, parágrafo único; art. 15, parágrafo único; e Lei federal $n^{\circ} 9.882 / 99$, art. $4^{\circ}$, $\S 2^{\circ}$ ), que deve ser proposto no prazo de 5 (cinco) dias.

Por sua vez, os acórdãos dos tribunais estaduais no exercício de sua função de controle abstrato ( $\mathrm{CF}$, art. 125 , $\S 2^{\circ}$ ) podem ser objeto de recursos, dentre eles o recurso extraordinário e mesmo o especial, quando alguma regra processual tenha sido desrespeitada no curso do julgamento.

A viabilidade do recurso extraordinário contra as decisões proferidas pelos Tribunais de Justiça estaduais no exercício da função de controle abstrato foi firmada na Reclamação 383/SP, relatada pelo Ministro MOREIRA ALVES, na qual se assentou seu cabimento quando a interpretação da norma constitucional estadual, que reproduz a norma constitucional federal de observância obrigatória pelos Estados, contrariar o sentido e o alcance desta. ${ }^{439}$

\footnotetext{
438 “Art. 317. Ressalvadas as exceções previstas neste Regimento, caberá agravo regimental, no prazo de cinco dias de decisão do Presidente do Tribunal, de Presidente de Turma ou do Relator, que causar prejuízo ao direito da parte".

439 Rcl. 383/SP. Relator: Ministro MOREIRA ALVES. Julgamento: 11/06/1992. Órgão Julgador: TRIBUNAL PLENO. Publicação: DJ 21-05-1993, p. 09765. Ement., vol. 01704-01, p. 01. RTJ vol. 0147-02, p. 0404.
} 
Em monografia sobre o tema, LÉO FERREIRA LEONCY vislumbra três hipóteses de cabimento do recurso extraordinário contra os acórdãos proferidos em sede de controle abstrato de constitucionalidade, a saber:

“a) Quando o Tribunal de Justiça deixa de constatar a inconstitucionalidade do parâmetro de controle estadual em face da Constituição Federal; b) Quando o Tribunal de Justiça oferece ao preceito constitucional de reprodução obrigatória sentido diverso do que o Supremo Tribunal Federal ofereceu ou ofereceria ao preceito constitucional federal reproduzido; c) Quando o Tribunal de Justiça adota no julgamento da ação direta procedimento ou atividade incompatível com a Constituição Federal." ${ }^{440}$

Importante aspecto a ser observado é o que diz respeito aos prazos para a interposição dos recursos.

Com fundamento na especialidade do processo de controle abstrato, o Supremo Tribunal Federal tem afirmado não serem a ele aplicáveis as normas do processo comum que preveem o prazo em dobro para recorrer, previsto no artigo 188 do Código de Processo Civil ${ }^{441}{ }^{442}$, nem a intimação pessoal dos advogados públicos. ${ }^{443}$

Embora no caso de ações ajuizadas diretamente no Supremo Tribunal Federal a inexistência de prazo recursal alargado possa não surtir consequências mais

\footnotetext{
${ }^{440}$ LEONCY, Léo Ferreira. Controle de constitucionalidade estadual: As normas de observância obrigatória e a defesa abstrata da Constituição do Estado-membro. São Paulo, Saraiva, 2007, p. 132.

441 "NÃO HÁ PRAZO RECURSAL EM DOBRO NO PROCESSO DE CONTROLE CONCENTRADO DE CONSTITUCIONALIDADE. - Não se aplica, ao processo objetivo de controle abstrato de constitucionalidade, a norma inscrita no art. 188 do CPC, cuja incidência restringe-se, unicamente, ao domínio dos processos subjetivos, que se caracterizam pelo fato de admitirem, em seu âmbito, a discussão de situações concretas e individuais. Precedente. Inexiste, desse modo, em sede de controle normativo abstrato, a possibilidade de o prazo recursal ser computado em dobro, ainda que a parte recorrente disponha dessa prerrogativa especial nos processos de índole subjetiva.” In: ADI-AgR 2130/SC, Relator Ministro CELSO DE MELLO, julgamento: 03/10/2001, Tribunal Pleno, DJ 14/12/2001. Ement. vol. 02053-03, p. 0485.

${ }^{442}$ No mesmo sentido: ADI $n^{\circ} 1.797$ AgR, Relator Ministro ILMAR GALVÃO. Julgamento: 22/11/2000, Tribunal Pleno. Publicação: DJ 23-02-2001, p. 84. Ement. vol. 02020-01, p. 80; AI n ${ }^{\circ}$ 633998/RS, Relatora Ministra CÁRMEN LÚCIA, decisão monocrática, DJ no 200, do dia 22/10/2008; AI nº 646265/GO, Relator Ministro MARCO AURÉLIO, decisão monocrática, DJ no 229, do dia 29/11/2007; RE 556331/MG, Relator Ministro MARCO AURÉLIO, decisão monocrática, DJ no 175, do dia 11/09/2007; AI n ${ }^{\circ}$ 639017/MG, Relator Ministro MARCO AURÉLIO, decisão monocrática, DJ nº 122, do dia 27/06/2007; RTJ 136/467; RTJ 144/3; RTJ 164/506; RTJ 170/801.

${ }^{443}$ ADI 1.797 MC-AgR-ED Relator Ministro ILMAR GALVÃO. Julgamento: 18/04/2001, Tribunal Pleno. Publicação: DJ 29-06-2001, p. 55. Ement. vol. 02037-02, p. 438.
} 
drásticas, em ações propostas nos Tribunais de Justiça estaduais a inaplicabilidade da regra de prazos recursais estendidos pode causar o não conhecimento do recurso extraordinário interposto contra o acórdão que julgou o processo. Os prejuízos aí são evidentes.

Haveria razão para aplicar supletivamente as regras referentes ao recurso extraordinário, em especial o prazo para a sua interposição, e afastar as regras gerais que tratam dos prazos recursais, sabendo-se que todas elas estão previstas no mesmo Código de Processo Civil?

Poder-se-iam formular argumentos em ambos os sentidos. Todavia, aqui, mais uma vez, o Supremo Tribunal Federal firmou sua jurisprudência no sentido de evidenciar a natureza especial do processo de controle abstrato, prestigiando a sua celeridade.

O amicus curiae, ainda que devidamente admitido no processo, não tem legitimidade para recorrer, tanto nas ações diretas de constitucionalidade ou inconstitucionalidade, como na arguição de descumprimento de preceito fundamental. Figura o amicus como mero auxiliar que não se equipara aos legitimados do controle abstrato, sendo pacífica a jurisprudência no sentido de inadmitir-lhe a interposição de recursos. ${ }^{444} 445$

${ }^{444}$ O STF firmou entendimento, na ADI/ED n ${ }^{\circ}$ 3.165/PB, no sentido de não serem cabíveis embargos de declaração por terceiros "estranhos" à relação processual nos processos objetivos de constitucionalidade: "Não são cabíveis os recursos interpostos por terceiros estranhos à relação processual nos processos objetivos de controle de constitucionalidade, nesses incluídos os que ingressam no feito na qualidade de amicus curiae. Com base nesse entendimento, o Tribunal, por maioria, não conheceu de embargos de declaração opostos contra acórdão proferido em ação direta de inconstitucionalidade, em que se apontava contradição entre parte dos fundamentos e a atribuição, sem ressalva, do efeito ex nunc à declaração de inconstitucionalidade da norma impugnada. Vencidos dos Ministros Carlso Britto e Gilmar Mendes que conheciam dos embargos de declaração, reputando presente o interesse recursal, anto o fato de ter havido sustentação oral do embargante.” In: ADI-ED n ${ }^{\circ}$ 3615/PB, Rel. Min. CARMEN LÚCIA, Pleno, Julg. em 17.03.2008.

${ }^{445}$ Na mesma esteira, a decisão proferida nos autos da ADPF 183-SP, relator Ministro CARLOS AYRES BRITTO: "Trata-se de embargos de declaração, opostos pelo Conselho Regional do Estado de São Paulo da Ordem dos Músicos do Brasil, contra a decisão pela qual adotei, no caso, o procedimento abreviado de que trata o art. 12 da Lei n ${ }^{\circ}$ 9.868/99. 2. Pois bem, incabíveis os presentes embargos. É que 'carece de legitimidade recursal quem não é parte na ação direta de inconstitucionalidade [ou arguição de descumprimento de preceito fundamental], mesmo quando, eventualmente, tenha sido admitido como amicus curiae' (ADI 3.582-ED, Rel. Min. Menezes Direito). Nesse sentido, menciono ainda ao seguintes arestos: ADI 3.615-ED, Rel. Min. Cármen Lúcia; ADI 3105-ED, Rel. Min. Cezar Peluso; ADI 2.591-ED, Rel. Min. Eros Grau. Ademais, o propósito do embargante é nitidamente infringente, não havendo nenhuma omissão ou obscuridade na decisão embargada. 3. Ante o exposto, não conheço dos embargos. Publique-se. Brasília, $1^{\circ}$ de setembro de 2009.” 
Por fim, o Supremo Tribunal Federal não admite o pedido de suspensão de liminar, previsto na Lei $\mathrm{n}^{\circ}$ 8.437/92, artigo $4^{\circ}$, em sede de controle abstrato de constitucionalidade. ${ }^{446}$

\subsubsection{O princípio da publicidade (CF, art. 93, IX; Lei federal $n^{0}$ 9.868/99, arts. 11, 21, $\S^{\circ}$ e 28; Lei federal $\left.n^{0} 9.882 / 99\right)$}

Em um Estado democrático e republicano, é natural que os cidadãos tenham direito de obter do Estado informações que constem de registros públicos. Nesse sentido, a Constituição Federal de 1988 garante o direito à informação (art. 5 XIV, XXXIII, XXXIV, $b$, e LX; e art. 37, § $3^{\circ}$, II).

Nas democracias, por princípio, as decisões devem ser tomadas em público, mediante processo igualmente acessível a todos. De fato, elucida BOBBIO:

"Como é bem conhecido, a democracia nasceu com a perspectiva de eliminar para sempre das sociedades humanas o poder invisível e de dar vida a um governo cujas ações deveriam ser desenvolvidas publicamente, ' $a u$ grand jour' (para usar a expressão de Maurice Joly). Modelo da democracia moderna foi a democracia dos antigos, de modo particular a da pequena cidade de Atenas, nos felizes momentos em que o povo se reunia na ágora e tomava livremente, à luz do sol, suas próprias decisões, após ter ouvido os oradores que ilustravam os diversos pontos de vista. Para denegri-la, Platão (que era um antidemocrático) a havia chamado de 'teatrocracia' (palavra que se encontra, não por acaso, também em Nietzsche).”447

BOBBIO afirma que uma das razões da superioridade da democracia sobre os Estados absolutos - que haviam revalorizado os “arcana imperii” (isto é,

${ }^{446}$ Pet. 2125-SP, decisão monocrática proferida pelo Ministro CARLOS VELLOSO, DJ nº. 179, do dia 15/09/2000; Pet. 2701, Relator Ministro MARCO AURÉLIO, DJ Nr. 108 do dia 10/06/2002. No mesmo sentido as Petições 1543-8 e 2229-2, apreciadas pelo então Presidente da Corte, ministro CARLOS VELLOSO, e 1120-1, pelo ministro CELSO DE MELLO.

${ }^{447}$ BOBBIO, Norberto. O futuro da democracia. $10^{\mathrm{a}}$ ed., tradução Marco Aurélio Nogueira, São Paulo, Paz e Terra, 2006, p. 41-42. 
as autoridades ocultas, misteriosas), defendendo com argumentos históricos e políticos que as decisões políticas fossem tomadas nos gabinetes secretos - seria “a convicção de que o governo democrático poderia finalmente dar vida à transparência do poder, ao 'poder sem máscara”", 448

A publicidade das decisões judiciais é um reflexo desse ideal democrático no campo do processo jurisdicional. Assim como todas as demais decisões do Poder Judiciário (CF, art. 93, IX, sujeita às restrições previstas no art. 50, LX), os atos processuais e as decisões proferidas em sede de controle abstrato devem obedecer ao princípio da publicidade.

Ao tratar da garantia processual da publicidade, ROBERTO JOSÉ FERREIRA DE ALMADA, esclarece que a “doutrina que se dedica ao estudo desse assunto sustenta que os atos de autoridade exercidos por delegação popular sempre devem estar fundados em premissas de índole cognitiva e jamais índole potestativa, para que se apresentem demonstráveis e controláveis”. 449

Se em um Estado democrático e republicano todo o poder emana do povo e em nome dele é exercido, os detentores do poder - que a eles é, portanto, delegado - devem prestar contas de seu exercício. A publicidade dos atos praticados no exercício do poder delegado é um potente instrumento para esta finalidade.

Mediante a publicidade e a motivação dos atos judiciais, o seu controle pode ser feito não só pelas partes do processo, mas também por toda a comunidade, a permitir que se averigúe se o poder está sendo exercido dentro das balizas constitucionais e legais. Como bem nota ALMADA:

${ }^{448}$ BOBBIO, Norberto. O futuro da democracia. $10^{\text {a }}$ ed., tradução Marco Aurélio Nogueira, São Paulo, Paz e Terra, 2006, p. 42.

449 ALMADA, Roberto José Ferreira de. A garantia processual da publicidade. São Paulo, Revista dos Tribunais, 2006, p. 16. 
"É nesse contexto que a publicidade, lado a lado com a motivação das decisões judiciais, mostra-se apta a cumprir a nobre missão de permitir, não apenas às partes do processo, mas igualmente a qualquer um do povo, jurisdicionados potenciais em sentido lato, a constatação concreta da lisura e da legalidade dos atos judiciais, particularmente exigindo que sejam comunicados todos e tantos quantos por eles possam se interessar, dando-selhes conhecimento geral por intermédio dos meios usuais de revelação.”"450

A publicidade dos atos judiciais pode ser enfocada através de dois pontos de vista: o primeiro relativo às próprias partes do processo e o segundo em relação a terceiros. Neste sentido, já ensinava CHIOVENDA:

"A publicidade das atividades processuais é um princípio que se pode entender de dois modos diferentes: ou como admissão dos terceiros (público) a assistir às atividades processuais; ou como necessidade entre as partes de que toda atividade processual tenha a presença de ambas. Num e noutro sentido, inclui-se a publicidade nos processos mais antigos (romano e germânico); e exclui-se, pelo menos em parte, de muitos processos intermédios.”451

A doutrina tem identificado a publicidade conferida às partes do processo como publicidade interna e aquela destinada à comunidade em geral como publicidade externa.

A publicidade interna deita raízes no liberalismo, do qual se extrai uma compreensão individualista do processo. Para essa concepção, bastava que as partes estivessem cientes dos atos e termos do processo de modo a assegurar-lhes a possibilidade de resguardar seus direitos e faculdades processuais. Sendo o juiz um mero aplicador da lei, concebida de forma racional e quase infalível, supunha-se não haver espaço

${ }^{450}$ ALMADA, Roberto José Ferreira de. A garantia processual da publicidade. São Paulo, Revista dos Tribunais, 2006, p. 16. Pondera, ainda, o autor que: "É impossível, portanto, não perceber a destacada importância que assume a publicidade dos atos praticados no processo pelo juiz, de modo a afastar a possibilidade das decisões se fundarem em motivos inconfessáveis. Ao lado da motivação das sentenças, a publicidade se põe a socorrer a democracia e a legalidade, estampando e tornando visíveis as atitudes dos agentes estatais delegados responsáveis pela jurisdição, particularmente dando eficácia aos direitos fundamentais associados à moralidade, à impessoalidade e à legalidade das condutas da Administração que, tanto quanto se passa no âmbito da exteriorização geral das condutas do Estado, aplicam-se igualmente à atividade pública da jurisdição.” In: Ibidem, p. 33.

${ }^{451}$ CHIOVENDA, Giuseppe. Instituições de Direito Processual Civil, v. 3. Tradução Paolo Capitanio, $1^{\text {a }}$ ed., Campinas, Bookseller, 1998, p. 105. 
para a criatividade judicial, motivo pelo qual a fiscalização externa se mostrava de somenos importância.

Sobre a correlação entre a influência liberal e a publicidade interna, ALMADA faz as seguintes considerações:

\begin{abstract}
"Bem ou mal, porém, essa duradoura fase de concepção liberal do direito deixou profundas cicatrizes no pensamento jurídico e, como não poderia deixar de ser, isso acabou por influenciar a própria noção historicamente atribuída à garantia da publicidade do processo e da sentença. É dessa época do pensamento jurídico que advém a noção de publicidade tão somente como exigência de serem cientificados os litigantes judiciais dos acontecimentos do processo capazes de prejudicar os seus interesses, dela fazendo um típico instrumento (garantia de segundo grau) de realização do contraditório - publicidade interna. No mais, particularmente no que interessa à revelação pública dos atos processuais, para a eventual controle e censura popular das atividades judiciais, e mesmo para legitimação das ações estatais realizadas no âmbito jurisdicional - publicidade externa supunha-se que a exigência da legalidade bem se prestava a cumprir as necessidades correlatas." 452
\end{abstract}

A publicidade interna está intimamente ligada ao exercício do contraditório, pois é imprescindível que as partes tenham ciência dos atos praticados pela parte contrária e pelo órgão jurisdicional para que tenham a oportunidade de sobre elas se manifestarem, dando vazão à dialética processual, que é a essência do contraditório. Por isso, a garantia do contraditório é identificada com a ciência bilateral dos atos e termos do processo e a possibilidade de reação. Esclarece ALMADA que a publicidade interna pode se dar de maneira imediata, quando a própria parte está presente ou tem contato direto com os atos processuais, e mediata, na hipótese de o ato processual ser divulgado por meios de comunicação. $^{453}$

No processo de controle abstrato, é necessário que todos os envolvidos - o requerente e os órgãos responsáveis pela edição da norma impugnada - tenham ciência dos atos praticados. Devem ter ciência, igualmente, aqueles que tiverem sido

452 ALMADA, Roberto José Ferreira de. A garantia processual da publicidade. São Paulo, Revista dos Tribunais, 2006, p. 62.

${ }^{453}$ Ibidem, p.127. 
admitidos como amici curiae, ainda que, como visto acima, não lhes seja conferida a possibilidade de recorrer das decisões (vide item 3.2.11, supra), a ensejar que possam, efetivamente, participar do procedimento, de modo que suas manifestações tenham a capacidade de influir na decisão a ser proferida, qualificando-a com maiores substratos e fundamentos.

Todavia, diante de uma expectativa de atuação social do poder público e em um cenário de Estado democrático de Direito, a publicidade interna, restrita às partes, já não mais se mostra suficiente.

De fato, a partir do momento em que o Estado passa a ser um protagonista na implementação de políticas públicas, voltadas à efetiva realização do bemestar da população, o Poder Judiciário também passa por uma transformação, a exigir do magistrado uma escolha entre alternativas exegéticas existentes para melhor alcançar os fins sociais do Estado. Neste contexto, a interpretação legal é mais ampla e está longe de ser uma atividade meramente mecânica (o juiz não é, aos moldes formulados por Montesquieu, “a boca da lei”, um mero autômato que a aplica no caso concreto). Tendo de escolher uma entre diversas opções, o juiz deve, necessariamente, justificar o porquê de sua escolha, explicando a razão pela qual entendeu ser aquela a melhor alternativa dentre as existentes.

Nessa perspectiva, assumem a motivação e a publicidade do processo um papel fundamental, pois a decisão judicial passa a interessar não só às partes, mas a toda a comunidade, ou ao auditório universal, como afirma MICHELE TARUFO:

"Conclui-se, então, que o significado constitucional do dever de motivação não pode incidir também sobre o estilo da motivação. Esta não pode ser dirigida somente aos sujeitos técnicos do processo (ou seja defensores e juiz), e nem tampouco ao auditório especializado, constituído por profissionais de direito. A motivação deve ser, ao contrário, potencialmente dirigida ao 'auditório universal' em conformidade com o lugar, o tempo e o contexto sócio-cultural no qual a decisão é pronunciada.”454

454 "Ne deriva allora che il significato costituzionale dell'obbligo di motivazione non può incidere anche sullo stile della motivazione. Questa non può essere diretta solo ai soggetti tecnici del processo (ossia difensori e giudici), e neppure all'uditorio specializzato costituito dai professionisti del diritto. La motivazione deve essere 
LUHMANN, ao tratar da legitimação pelo procedimento, reconhece que nem todo aquele que se interessa pelos problemas tratados em juízo ou que pode ser afetado pelas decisões tem acesso ao procedimento ${ }^{455}$, todavia, ressalta que esse fato não significa que a atitude dos não-participantes seja irrelevante para a legitimação pelo procedimento, pois aquela - vista como o reconhecimento de decisões como obrigatórias - só ocorre quando o consenso se exprime em grande dimensão ou é simulado em decorrência da não-declaração de falta de consenso. ${ }^{456}$

Portanto, a ampla publicidade é imprescindível à legitimação da jurisdição, em particular da jurisdição constitucional em sentido estrito, cujo ato decisório pode acarretar a invalidação de ato legislativo aprovado em processo público e aberto, ao menos em tese, à ampla participação popular.

\section{Como evidencia LUHMANN:}

“A publicidade disto é essencial para permitir uma participação desinteressada do público no procedimento. O decurso do processo tem de poder ser presenciado pelos não-participantes. Trata-se de facilitar aí o acesso, não tanto quanto a presença atual, mas sim quanto à ida efetiva, quanto à assistência. É decisivo que exista essa possibilidade. Ela fortalece a confiança, ou pelo menos impede a criação daquela desconfiança que se liga a todas as tentativas de guardar segredo. A função do princípio da publicidade do processo jurídico consiste na criação de símbolos, na

invece potenzialmente diretta all' 'uditorio universale' in un'accezione connel luogo, nel tempo e nel contesto sócio-culturale nel quale la decisione viene pronunciata.” In: TARUFO, Michele. Il significato costituzionale dell'obrigo di motivazione. In: GRINNOVER, Ada Pelegrini; DINAMARCO, Cândido Rangel; WATANABE, Kazuo (orgs.). Participação e processo. São Paulo, Saraiva, 1988, p. 50.

${ }^{455}$ LUHMANN, Niklas. Legitimação pelo procedimento. Tradução Maria da Conceição Côrte-Real, Brasília, Editora Universidade de Brasília, 1980, p. 103.

${ }^{456}$ Ibidem, p. 104. E acrescenta o autor: "Para poder estabilizar essas conjecturas de consenso relativas ao caráter obrigatório da decisão oficial, tem também de se fazer participar no procedimento os não-participantes. Claro que eles não terão acesso ao papel de oradores, mas o procedimento, como drama, também a eles se destina. Têm de chegar à convicção de que tudo se passa naturalmente, de que pelo esforço sério, justo e intenso se investigará a verdade e a justiça e que, eventualmente, com a ajuda destas instituições, também eles recuperarão os seus direitos. Se esta atitude está efetivamente divulgada, ou se ela foi supostamente divulgada com base na situação de comunicação, aquele que se quer revoltar contra uma decisão obrigatória não pode contar com o apoio dos outros. O seu protesto ser-lhe-á imputado e não atribuído a uma falha da instituição. Aparece como teimosia, critiquice, estupidez ou, pelo menos, como uma atitude de vida extravagante e praticamente irracional. Com esta interpretação a condição do problema não se pode divulgar, fica apenas circunscrita ao único interessado”. In: Ibidem, p. 104. 
ampliação do procedimento a um drama que simboliza a decisão correta e justa e para tal não é necessária a presença contínua duma parte maior ou menor da população. Basta um conhecimento geral e indefinido de que tais procedimentos se realizam continuamente e de que qualquer pessoa pode, se necessitar, informar-se com maior exatidão sobre eles.” ${ }^{457}$

Não basta, portanto, que o procedimento tenha se realizado com toda a correção, segundo a mais estrita observância à lei. É imprescindível que os seus atos sejam públicos e amplamente divulgados, para que todos tenham a eles acesso e possam, individualmente, se assim o quiserem, aferir a sua legalidade, correção e justiça.

É, portanto, através da publicidade que se garante a transparência do processo judicial, a permitir a fiscalização da comunidade sobre o exercício da função jurisdicional e o acerto de suas decisões, de modo a evitar a arbitrariedade e as decisões casuísticas e contribuir para a democratização do processo. ${ }^{458}$

Por outro lado, tendo em vista que a decisão proferida no controle abstrato tem eficácia geral, erga omnes, em tese todos teriam interesse em acompanhar o processo de controle, pois podem ser potencialmente afetados pela decisão.

No controle abstrato de constitucionalidade, a publicidade possui o fundamental papel de dar conhecimento acerca da validade ou invalidade da lei e do momento a partir do qual ocorrem estes fenômenos. Da mesma forma que a publicação da lei é o ato que a torna obrigatória, a publicação do julgamento das ações de controle de constitucionalidade é o ato que suprime a validade da lei, confirma a sua eficácia e validade ou

\footnotetext{
${ }^{457}$ LUHMANN, Niklas. Legitimação pelo procedimento. Tradução Maria da Conceição Côrte-Real, Brasília, Editora Universidade de Brasília, 1980, p. 105.

${ }^{458}$ Para BARACHO, o "processo constitucional assenta-se em determinados princípios que consolidam sua concepção e práticas. O princípio da publicidade é uma garantia imprescindível, para possibilitar a participação da cidadania, pelo que todos têm direito a um processo público. A publicidade processual está vinculada ao sistema democrático de governo, conforme afirmou Couture. É o mais precioso instrumento de fiscalização popular sobre as normas dos magistrados e defensores. No processo contemporâneo, em oposição ao procedimento secreto inquisitivo, surgem os princípios da publicidade e da oralidade que são correlatos. A publicidade não é apenas política, mas também técnico-jurídica. Contribui para assegurar a confiança da opinião publica na administração da justiça. Com a publicidade, o ato jurisdicional pode ser julgado socialmente, expondo-se às críticas das partes e de seus representantes, evitando o juízo arbitrário.” In: BARACHO, José Alfredo de Oliveira. Direito Processual Constitucional: aspectos contemporâneos. Belo Horizonte, Editora Fórum, 2006, p. 19.
} 
fixa um momento para a sua retirada do ordenamento (Lei federal $n^{\circ} 9.868 / 99$, art. 27, e Lei federal $n^{\circ} 9.882 / 99$, art. 11).

É por estes motivos que a Lei federal $n^{\circ}$ 9.868/99 determina, em seu artigo 28, que “dentro do prazo de 10 (dez) dias após o trânsito em julgado da decisão, o Supremo Tribunal Federal fará publicar em seção especial do Diário de Justiça e do Diário Oficial da União a parte dispositiva do acórdão”, proferido tanto na ação direta de inconstitucionalidade como na ação declaratória de constitucionalidade, havendo disposição análoga no tocante à arguição de descumprimento de preceito fundamental (Lei federal $\mathrm{n}^{\mathrm{o}}$ 9.882/99, art. $8^{\circ}$, § $2^{\text {o459 }}$ ). A mesma sistemática se aplica às decisões cautelares proferidas em controle abstrato [Lei federal $\mathrm{n}^{\circ}$ 9.868/99, art. 11 (ADI) ${ }^{460}$ e art. 21, parágrafo único (ADC)]. ${ }^{461}$ Embora a lei que trate da arguição de descumprimento de preceito fundamental não traga dispositivo semelhante, entendo que a regra seja aí plenamente aplicável pela identidade de natureza das ações em questão, mediante analogia.

Ressalte-se que, como visto anteriormente, o Supremo Tribunal Federal entende que o sistema processual nacional permite o cumprimento das decisões proferidas em sede de controle abstrato antes do julgamento final da lide, em razão do poder geral de cautela, bastando a publicação da ata da sessão de julgamento para que a decisão surta efeitos (eficácia). Todavia, é necessário ressaltar, como mencionei acima, que o início de validade da decisão (inclusive para efeitos recursais), fixada na Questão de Ordem da ADI no

\footnotetext{
459 “Art. $8^{\circ}$ Omissis.

[...] §2 $2^{\circ}$ Dentro do prazo de 10 (dez) dias contado a partir do trânsito em julgado da decisão, sua parte dispositiva será publicada em seção especial do Diário da Justiça e do Diário Oficial da União.”

460 "Art. 11. Concedida a medida cautelar, o Supremo Tribunal Federal fará publicar em seção especial do Diário Oficial da União e do Diário da Justiça da União a parte dispositiva da decisão, no prazo de 10 (dez) dias, devendo solicitar as informações à autoridade da qual tiver emanado o ato, observando-se, no que couber, o procedimento estabelecido na Seção I deste Capítulo.”

461 “Art. 21. Omissis.

Parágrafo único. Concedida a medida cautelar, o Supremo Tribunal Federal fará publicar em seção especial do Diário Oficial da União a parte dispositiva da decisão no prazo de 10 (dez) dias, devendo o Tribunal proceder ao julgamento da ação no prazo de 180 (cento e oitenta) dias, sob pena de perda as sua eficácia.”
} 
711, se dá em outro momento, qual seja, quando da publicação no Diário da Justiça da ata da sessão de julgamento ( $v$. princípio da irrecorribilidade, item 3.2.11, supra) ${ }^{462}$.

Colocadas essas questões relativas à publicidade, resta concluir que a prática do Supremo Tribunal Federal nesse ponto é digna dos mais elevados encômios. Realmente, as sessões de julgamento daquele Tribunal são transmitidas ao vivo pela televisão; o Tribunal possui sítio na internet com ampla gama de informações, atualizadas permanentemente, no qual se pode consultar o andamento do processo, a jurisprudência do Tribunal, a íntegra dos acórdãos e decisões e, mais recentemente, todas as peças processuais. Por outro lado, os acórdãos proferidos são publicados integralmente, contendo, inclusive, a transcrição das notas taquigráficas relativas aos debates em Plenário, de modo a contribuir para uma melhor compreensão da decisão tomada e de seus limites.

Apenas uma ressalva pode ser feita aqui: a transmissão televisiva é veiculada apenas pelas redes por assinatura e por satélite, inexistindo um canal aberto de transmissão das sessões de julgamento. A abertura do sinal da TV Justiça sem dúvida é um objetivo que traria uma contribuição ainda maior à democratização da justiça brasileira.

Por fim, cabe mencionar que o Conselho Nacional de Justiça editou a Resolução $n^{0}$ 79, de 9 de junho de 2009, que dispõe sobre a transparência na divulgação das atividades do Poder Judiciário e dá outras providências, permitindo livre acesso a qualquer pessoa às informações alusivas à gestão administrativa, financeira e orçamentária dos tribunais e conselhos (art. $2^{\circ}$, III), tudo a evidenciar o grau de publicidade existente hoje no Poder Judiciário.

\footnotetext{
462 "O deferimento da medida cautelar produz seus efeitos a partir da data da publicação da ata de julgamento no Diário de Justiça da União.” In: ADI no 711, Relator Ministro NERY DA SILVEIRA. Julgamento: 05/08/1992. Órgão julgador: Tribunal pleno. Publicação: D.J. 11-06-1993, p. 11529; ement. vol. 01707-01, p. 06.
} 


\subsubsection{O princípio da motivação e da fundamentação das decisões judiciais (CF, art. 93, IX)}

Este também é um princípio que tem sede constitucional (CF,

art. 93, IX).

BARACHO, asseverando a importância da motivação das decisões jurisdicionais, esclarece que:

“a motivação do provimento jurisdicional é norma constitucional para a jurisdição, em vista da qual todas as decisões judiciais devem ser motivadas. Entende-se que a obrigação constitucional da motivação é condição mínima de efetividade do princípio da legalidade da atividade jurisdicional da sujeição à lei”. ${ }^{463}$

Todavia, nem sempre a motivação e a fundamentação ostentaram sede constitucional.

Como bem esclarece JOSÉ CARLOS BARBOSA MOREIRA, embora a história do direito registre antigos precedentes de decisões judiciais que necessitavam ser motivadas, a prática generalizada da motivação teve início nas legislações ocidentais a partir da segunda metade do século XVIII, passando a constituir um traço comum a quase todas as grandes codificações processuais do século XIX. ${ }^{464}$

A motivação das decisões veio inicialmente ligada a uma ideia de racionalização da atividade jurisdicional, possuindo, assim, natureza técnica. Volta-se, nesse sentido, a viabilizar a compreensão do julgado, a permitir às partes que recorram da decisão e às instâncias superiores que conheçam as suas razões.

\footnotetext{
${ }^{463}$ BARACHO, José Alfredo de Oliveira. Direito processual constitucional: Aspectos contemporâneos. Editora Fórum, Belo Horizonte, 2006, p. 18.

${ }^{464}$ BARBOSA MOREIRA, José Carlos. A motivação das decisões judiciais como garantia inerente ao Estado de Direito. In: Temas de direito processual: Segunda Série. São Paulo, Saraiva, 1980, p. 83.
} 
Cita o ilustre processualista carioca que, na tradição lusobrasileira, a obrigatoriedade da motivação deita raízes no Código Filipino, cuja Ordenação do Livro III, Título LXVI, § 7º, princípio, assim estatuía:

"E para as partes saberem se lhes convém apelar, ou agravar das sentenças definitivas, ou vir com embargos a elas, e os Juízes da mor alçada entenderem melhor os fundamentos, por que os Juízes inferiores se movem a condenar, ou absolver, mandamos que todos nossos Desembargadores, e quaisquer outros Julgadores, ora sejam Letrados, ora o não sejam, declarem especificamente em suas sentenças definitivas, assim na primeira instância, como no caso da apelação, ou agravo, ou revista, as causas, em que se fundaram a condenar, ou absolver, ou a confirmar, ou revogar." 465

Sobre esse ponto de vista técnico, esclarece BARBOSA MOREIRA que a justificativa para o dever de motivar, além dos referidos argumentos históricos, se funda na necessidade de aferição da imparcialidade do juiz, da legalidade da decisão e do direito de as partes serem ouvidas e ver examinadas pelo órgão julgador as questões que houverem suscitado. ${ }^{466}$

Todavia, o dever de motivar as decisões possui uma outra dimensão, a par da técnica. Esta se insere dentre as premissas do Estado democrático de Direito. Realmente, como nas democracias o poder é exercido com fundamento em lei e não na vontade pessoal do julgador, é necessário que a decisão demonstre efetivamente ter sido tomada com base na lei, mediante a fundamentação racional de seus termos.

MICHELE TARUFO demonstra que o dever de motivar as decisões se funda em duas razões distintas, a primeira estritamente ligada à exigência de funcionamento do processo e da organização centralizada da magistratura; vem do racionalismo funcional e burocrático e se volta a facilitar a conexão entre a sentença e a impugnação; serve às partes que, conhecendo os motivos da decisão, podem decidir se devem impugná-la e individualizar melhor os motivos da impugnação; e serve, também, ao órgão superior, que poderá melhor analisar a sentença recorrida, conhecendo as razões adotadas pelo

${ }^{465}$ BARBOSA MOREIRA, José Carlos. A motivação das decisões judiciais como garantia inerente ao Estado de Direito. In: ${ }^{466}$ Ibidem, p. 87-88. 
juízo que a proferiu. A segunda razão do dever de motivar a decisão, que não exclui a função de racionalidade do sistema, mas a supera, funda-se na visão da motivação como garantia. Sua inspiração vem da ideologia democrática da justiça, que aflora no iluminismo francês e se manifesta, sobretudo, após a Revolução: a função da motivação volta-se a assegurar o controle externo por parte do povo acerca do modo pelo qual os juízes exercem o poder que a eles é delegado. ${ }^{467}$

A motivação como instrumento endoprocessual é, geralmente, prevista nos códigos de processo, ao passo que a garantia da motivação costuma possuir sede constitucional.

No Código de Processo Civil de 1973, a motivação está prevista no artigo 131, que prescreve ao juiz o dever de apreciar "livremente a prova, atendendo aos fatos e circunstâncias constantes dos autos, ainda que não alegados pelas partes; mas deverá indicar, na sentença, os motivos que lhe formaram o convencimento". De fato, o artigo 458 inclui dentre os requisitos essenciais da sentença "os fundamentos, em que o juiz analisará as questões de fato e de direito" (inciso II), obrigação que se estende aos acórdãos, por força do previsto no artigo 165.

Todavia, até a Constituição de 1988, a garantia da motivação não estava inserida no texto constitucional.

A motivação das decisões judiciais mostra-se necessária, sobretudo, para que possa haver o controle da atividade jurisdicional. BARACHO invoca precedente da jurisprudência espanhola (STC 55/87) no qual se afirmou que "a exigência de motivação das sentenças judiciais relaciona-se de maneira direta com o princípio do Estado Democrático de Direito (art. 1, CE), sustentando a legitimidade da função jurisdicional”. 468

\footnotetext{
${ }^{467}$ TARUFO, Michele. Il significato costituzionale dell'obrigo di motivazione. In: GRINOVER, Ada Pellegrini; DINAMARCO, Cândido Rangel; WATANABE, Kazuo (orgs.). Participação e processo. São Paulo, Saraiva, 1988, p. 38.

${ }^{468}$ BARACHO, José Alfredo de Oliveira. Direito processual constitucional: Aspectos contemporâneos. Editora Fórum, Belo Horizonte, 2006, p. 19.
} 
De fato, como bem elucida TARUFO, o dever de motivar nasce da crise do Estado autocrático e apartado da sociedade civil. ${ }^{469}$ A passagem do Estado absoluto - ou, na época moderna, do Estado autoritário ou totalitário - ao Estado democrático implica no fim do poder absoluto e oculto do Estado. ${ }^{470}$ No plano jurisdicional, o poder do juiz não se legitima enquanto exercício de autoridade absoluta, mas, sim, quando o juiz presta contas do modo pelo qual exerce o poder que lhe foi delegado pelo povo, que é o primeiro e verdadeiro titular da soberania. ${ }^{471}$

Conclui TARUFO, a afirmar que o exercício do poder jurisdicional deve, assim, ser transparente, racional e controlável, como o exercício de qualquer poder no âmbito do Estado democrático de Direito. ${ }^{472}$

A motivação permite delimitar quais os "vícios”, “causas”,
“motivos" ou "fundamentos" nos quais se baseou a decisão para a análise da

${ }^{469}$ Nas palavras do autor: "L’obbligo constituzionale de motivazione nasce infatti dalla crise dello Stato persona, autocratico ed estraneo rispetto alla società civile, e dal conseguente affermarsi del principio per cui la sovranità spetta al popolo. Sul piano della giurisdizione, ciò significa che la giustizia non è più uma manifestazione della voluntà del sovrano, o del Führerprinzip, ma risulta dall'esercizio di um potere che il popolo ha delegato al giudice.” In: TARUFO, Michele. Il significato costituzionale dell'obrigo di motivazione. In: GRINOVER, Ada Pellegrini; DINAMARCO, Cândido Rangel; WATANABE, Kazuo (orgs.). Participação e processo. São Paulo, Saraiva, 1988, p. 41.

470 "A questa trasformazione del modo di concepire la sovranità e il titolo in base al quale essa si traduce nell'esercizio della giurisdizione, corrisponde una profonda trasformazione nella concezione del potere. Il passaggio dallo Stato assoluto, o - in epoca moderna - dallo Stato autoritario o totalitario, allo Stato democratico di diritto, implica la fine del potere assoluto e occulto dello Stato. Nello Stato democratico di diritto il potere non è assoluto, e soprattutto non è oculto: al contrario, vige il princípio di trasparenza, o di 'maximale Diskitierbarkeit' dell'esercizio potere, dato che la sua legittimità non è più fondata sul principio di autorità, ma sulla legittimazione democratica. In altri termini, lo Stato di diritto si pone necessariamente como rechtsfertigender Staat, ossia come forma politica che si legittima in quanto giustifica il modo in cui il potere viene esercitato.” In: TARUFO, Michele. Il significato costituzionale dell'obrigo di motivazione. In: GRINOVER, Ada Pellegrini; DINAMARCO, Cândido Rangel; WATANABE, Kazuo (orgs.). Participação e processo. São Paulo, Saraiva, 1988, p 41.

471 "Sul piano della giurisdizione, ciò significa che il provvedimento del giudice non si legittima in quanto esercizio di autorità assoluta, ma in quanto il giugice renda conto del modo in cui esercita il potere che gli è stato delegato dal popolo, che è il primo e vero titolare della sovranità. Sonde l'obbligo di giustificare la decisione, che risponde sia alla necessità di dimostrarne la fondatezza in fatto e in diritto, sia alla necessità di permettere che tale fondatezza sia diskutierbar, cioè sai controllabile dall'esterno in modo diffuso.” In: Ibidem, p. 41.

${ }^{472}$ Ibidem, p. 41-42. 
constitucionalidade da norma e também é de extrema relevância nos casos de decisões interpretativas ou de declaração de nulidade parcial. ${ }^{473}$

Em particular no que tange ao controle de constitucionalidade, a motivação assume uma importância superlativa. De fato, deve-se ter em vista que o controle abstrato de constitucionalidade tem por finalidade a verificação de conformidade das normas jurídicas em face da Constituição, podendo acarretar sua invalidação. Se a aprovação da lei ou espécie legislativa deve contar, por sua própria natureza, com a discussão pública do projeto de lei no Parlamento, com abertura ampla à participação popular, o processo que pode levar à sua invalidação (nesse caso pela via jurisdicional), deve, por simetria, possuir a mesma natureza pública, de modo a permitir e assegurar o acompanhamento de seu desenvolvimento pelos cidadãos. Assim, a final, pode-se aquilatar a correção da decisão tomada, permitindo atuar sobre ela a crítica social, tudo como pressuposto de legitimação democrática da decisão a ser tomada.

Também quando o Tribunal declara uma norma inconstitucional sem redução de texto ou aplica a técnica da interpretação conforme a Constituição, a fundamentação é importantíssima, de modo que se possa entender perfeitamente o sentido que o Tribunal extrai da norma para que ela possa ser considerada constitucional e, em contrapartida, os sentidos e interpretações que se mostrem incompatíveis com a Constituição.

Por outro lado, o princípio da motivação assume um relevante papel na jurisdição constitucional no caso de colisão entre princípios.

Admitindo-se a possibilidade de ponderação entre princípios constitucionais que regem a mesma matéria, quando a incidência de um princípio não exclui a do outro, buscando-se a aplicação na maior medida possível, segundo as características do caso concreto, a motivação mostra-se fundamental para aquilatar a razoabilidade da decisão.

\footnotetext{
${ }^{473}$ CANOTILHO, José Joaquim Gomes. Direito constitucional e teoria da Constituição. $7^{\text {a }}$ ed., Coimbra, 2003, p. 1325.
} 
Realmente, como a norma principiológica não confere previamente os limites para a sua aplicação, a incidência em situação concreta de um princípio em maior grau que de outro - ambos em tese aplicáveis à espécie - deve ser amplamente fundamentada pelo tribunal ou corte constitucional, pois a legitimidade da decisão e a possibilidade de sua compreensão e assimilação dependem, justamente, de sua fundamentação.

PAULO GUSTAVO GONET BRANCO, afirma que a "ampla participação de um universo aberto de intérpretes da Constituição somente surtirá efeitos legitimadores se houver deliberação que sopese todos os motivos por que uma ou outra linha de solução foi acolhida ou rejeitada”. ${ }^{474}$ Enfatiza, assim, a importância da fundamentação dessas decisões:

"Se a necessidade de se ouvir uma comunidade variada de interessados, por si, já é fator de limitação ao subjetivismo a que se inclinam os juízos de ponderação, é na exigência da fundamentação que essa barreira se vê reforçada. A necessidade de fundamentar decisórios há de conter o julgador e, simultaneamente, constitui o mecanismo assecuratório de racionalidade e representatividade da jurisdição constitucional, robustecendo a sua legitimidade no sistema democrático., ${ }^{775}$

A jurisdição constitucional, na medida em que se volta a preservar princípios e garantias constitucionais pode, eventualmente, contrariar os interesses de grupos sociais ou até da maioria da sociedade ${ }^{476}$, revelando-se como ato contramajoritário. Apenas a fundamentação lógico-racional será capaz de conferir legitimidade ao que for decidido, pois, ainda que a decisão não agrade a maioria das pessoas, expondo os seus

\footnotetext{
${ }^{474}$ BRANCO, Paulo Gustavo Gonet. Juízo de ponderação na jurisdição constitucional. São Paulo, Saraiva, 2009, p. 239.

${ }^{475}$ Ibidem, p. 239.

476 "No contexto do constitucionalismo, em que se privilegia a proteção de valores fundamentais mesmo quando estes colidem com interesses acidentais das maiorias, o juiz constitucional não deve buscar um inexorável apoio de fato na maioria dos cidadãos -as suas decisões não necessitam coincidir com pesquisas de opinião. A responsabilidade judicial, máxime na jurisdição constitucional, está em escorar as decisões em razões jurídicas assentadas nos princípios e sobretudo, nos direitos fundamentais que ela proclama. Como argúi Sieckmann, 'uma concepção melhor fundamentada racionalmente pode impor-se sobre uma concepção majoritária baseada em interesses fortes, mas não tão bem fundamentados.” In: Ibidem, p. 247.
} 
fundamentos o tribunal pode demonstrar que a decisão se destina à proteção dos princípios e valores constitucionais.

Enfim, a demonstrar a elevada importância do dever de fundamentar, finalizo o presente capítulo com a célebre frase de BENTHAM, para quem na legislação, na judicatura, ou em toda atividade humana em que o agente deva se mostrar confiável para o público ou para uma parte dele, fundamentar é, em relação à retitude da conduta, um teste, um parâmetro, uma segurança, ou uma fonte de interpretação, pois as boas leis são aquelas para as quais boas razões podem ser dadas; e as boas decisões são aquelas para as quais boas razões podem ser dadas. ${ }^{477}$

\subsubsection{O princípio da irrescindibilidade (Lei federal $n^{\circ} 9.868 / 99$, art. 26 e Lei federal $n^{\circ}$} 9.882/99, art. 12)

A possibilidade de ajuizamento de ação rescisória contra decisões proferidas em controle abstrato de constitucionalidade foi decidida inicialmente pelo Supremo Tribunal Federal na Ação Rescisória 878/SP. A ação, proposta pelo ilustre advogado THEOTONIO NEGRÃO buscava a rescisão de acórdão proferido na representação de inconstitucionalidade 665, que havia declarado inconstitucional decreto paulista que tratava de matéria notarial. O autor era titular de cartório de registro de imóveis, que tinha sido prejudicado pela anulação do decreto, pois perdeu a serventia pela qual havia optado, fundamentando aí o seu interesse pelo feito.

\footnotetext{
477 "In legisltation, in judicature, in every line of human action in which the agent is ought to be accountable to the public or any part of it,-giving reasons is, in relation to rectitude of conduct, a test, a standart, a security, a source of interpretation. Good laws are such laws for which good reasons can be given; good decisions are decisions for which good reasons can be given”. In: BENTHAM, Jeremy. Rationale of judicial evidence, specially applied to English practice, v. 1. Londres, Hunt and Clarke, 1827, p. 530. Disponível em: $<$ http://books.google.com.br/books?ei=Muy7SpGADZautgfPntXDDQ\&ct=result\&q=Rationale+of +judicial+evid ence:+specially+applied+to+English+practice, + Volume+1\&spell=1\&oi=spell $>$. Acesso em 05.01.2010.
} 
A ação teve como relator o Ministro SOARES MUÑOZ, que, embora tenha entendido que o particular fosse parte ilegítima para a ação, manifestou-se favoravelmente ao cabimento da rescisória contra o acórdão da representação de inconstitucionalidade, em virtude de encontrarem-se presentes na ação originária “os pressupostos do cabimento do 'judicium rescisorium', vale dizer: lide contenciosa, sentença sobre o mérito e a coisa julgada”, 478

Este entendimento não foi, todavia, acatado pelos demais Ministros da Corte. O Ministro revisor, RAFAEL MAYER, entendeu que seria cabível não só a preliminar de ilegitimidade de parte como a que contestava o cabimento da ação rescisória em face da própria natureza da declaração de inconstitucionalidade. ${ }^{479}$

O voto do Ministro revisor foi seguido pelos demais membros da Corte, realçando do caráter político da representação de inconstitucionalidade, no qual não teria cabimento a ação rescisória. ${ }^{480}$

Também entendendo que a irrescindibilidade dos julgados seja norma implícita decorrente da natureza especialíssima da jurisdição de controle abstrato de

\footnotetext{
${ }^{478}$ AR 878/SP. Relator: Min. SOARES MUÑOZ. Revisor: Min. RAFAEL MAYER. Julgamento: 19/03/1980, Tribunal Pleno. Publicação: DJ 06-06-1980, p. 04134. Ement. 01174-01, p. 029, RTJ vol. 94-01, p. 49.

479 "Mas esta preliminar está interligada com a do cabimento da ação rescisória pois é o próprio nível, o contexto e as implicações da declaração de inconstitucionalidade que se não amoldam ao quadro do juízo rescidente. Questiona-se, no caso, a impossibilidade que haveria em levar o Senado a editar nova resolução pela qual revogasse a suspensão da lei declarada inconstitucional. Mas também sob outro prisma, o de que a declaração da inconstitucionalidade em tese importa a desconstituição, a nulificação da própria lei em si, como feito imediato da sentença desconstitutiva, a dificuldade se apresenta na impossibilidade de restaurar o que foi desconstituído, pois se diz com razão que os efeitos da sentença são imutáveis.” In: Ibidem.

${ }^{480}$ Veja-se, a título de exemplo, trecho do voto do Ministro MOREIRA ALVES: “A meu ver, a ação direta de declaração de inconstitucionalidade é um meio de controle político da Constituição, que é deferido, em caráter excepcionalíssimo, a esta Suprema Corte. O eminente Procurador-Geral da República é o titular dessa representação, apenas para o efeito de provocar, ou não, o Tribunal, porque ele, como órgão político - já que se trata de ação de natureza política, pois o que se decide são os limites da atuação de dois Poderes conjugados ao elaborar uma lei -, pode encaminhar, ou não, o pedido. Mas, uma vez encaminhado, nem mesmo ele pode mais retirá-lo. E mais. Ainda que seja contrário ao próprio pedido que encaminha, o Regimento só lhe defere a possibilidade de dar parecer contrário. [...] E por ser ela instrumento de controle político da constitucionalidade da lei em tese, e não estritamente meio de prestação jurisdicional, não se me afigura possível sujeitá-la à ação rescisória prevista no Código de Processo Civil.” In: AR 878/SP. Relator: Min. SOARES MUÑOZ. Revisor: Min. RAFAEL MAYER. Julgamento: 19/03/1980, Tribunal Pleno. Publicação: DJ 06-06-1980, p. 04134. Ement. 01174-01, p. 029, RTJ vol. 94-01, p. 49..
} 
constitucionalidade, é a opinião de TAVEIRA BERNARDES, embora com fundamentação diversa daquelas apresentadas nos votos da Ação Rescisória 878/SP:

"O que parece explicar a irrescindibilidade é a maior importância que se deve dar à coisa julgada nas decisões do controle abstrato de constitucionalidade. Vale dizer, são razões ligadas ao maior peso desses pronunciamentos à estabilidade das relações jurídicas. Daí o motivo de considerar a irrescindibilidade um princípio em vez de uma regra.

Transitadas em julgado, as decisões finais de mérito dos processos de fiscalização abstrata devem inspirar total estabilidade. Embora não desfrutem de persuasão racional unânime, hão de, pelo menos, despertar a confiança em que não serão modificadas no futuro. Ou seja, os destinatários da atividade de 'legislação negativa' tendem a acreditar que referidos pronunciamentos são estáveis, motivo a mais para que todas as situações jurídicas a eles se harmonizem definitivamente.”481

Com a devida vênia, não me parece que o óbice ao ajuizamento da ação rescisória decorra da própria natureza das ações diretas de controle de constitucionalidade. Embora a maioria das hipóteses permissivas da rescisão, previstas no artigo 485 do Código de Processo Civil, sejam incabíveis no processo de controle abstrato, algumas delas, em tese, não seriam inviáveis (como v.g. aqueles previstos nos incisos I, IV e IX do referido dispositivo). Como procurei demonstrar ao longo do presente estudo, embora as ações de controle abstrato de constitucionalidade sejam ações regidas por um processo especial e sujeitas a procedimentos e até princípios próprios, em sua essência não deixam de ser processos jurisdicionais. Possuindo a natureza jurisdicional, as suas decisões finais poderiam, em tese, estar sujeitas à ação rescisória, se presentes os requisitos para tanto.

Vislumbre-se, por exemplo, a hipótese de um acórdão em ação direta de inconstitucionalidade que não conte com o voto da maioria absoluta dos julgadores e que essa situação não tenha sido notada sequer em sede de embargos de declaração. O fato impediria o trânsito em julgado da decisão? Parece-me que não. Seria razoável a manutenção de uma decisão com essa espécie de vício? Mais uma vez, a resposta parecer ser negativa. ${ }^{482}$

\footnotetext{
481 BERNARDES, Juliano Taveira. Controle abstrato de constitucionalidade: Elementos materiais e princípios processuais. São Paulo, Saraiva, 2004, p. 472.

482 Não se olvide que o controle concentrado de constitucionalidade é realizado também perante os órgãos especiais ou os plenários dos tribunais de justiça estaduais, nos quais o maior número de membros e a quantidade de processos nos quais não se exige o voto da maioria absoluta dos membros poderia levar involuntariamente à
} 
Apondo crítica ao dispositivo legal que veda a utilização de ação rescisória contra os acórdãos proferidos pelo Supremo Tribunal Federal em processos objetivos, PALU opina no seguinte sentido:

"Não é a melhor solução, data venia, ainda que se considere que nos processos objetivos 'não há partes propriamente ditas, não há juízes impedidos e não se admite a desistência. São ouvidos os órgãos que elaboram a lei ou o ato impugnado para que prestem informações e não para defender o direito, próprio ou alheio; e tais informações podem até ser dispensadas conforme o Regimento Interno do STF'.

Veja-se que o próprio Supremo Tribunal Federal reconheceu, em duas oportunidades ao menos (cf. RTJ 147/751), o impedimento de Ministros da Corte para participar de seção de julgamento de processo objetivo: em um caso, Ministro que havia sido Procurador-Geral da República e recusara representação para propor a ação direta (ADIn 55-DF, rel. Min. Octávio Gallotti) e em outro, de Ministro que, na condição de Presidente do Superior Tribunal Eleitoral, presta informações no processo de fiscalização abstrata (ADIn 267-DF, rel. Min. Celso de Mello). Há que se indagar, acaso houvesse o julgamento sem qualquer questão de ordem, partícipe o ministro impedido com voto decisivo em um ou outro sentido, se não seria o caso de ação rescisória." ${ }^{883}$

Todavia, por razões de segurança e previsibilidade das relações jurídicas e de estabilidade do sistema, como exposto acima, a impossibilidade de manejo de ação rescisória contra os julgados em controle abstrato é medida coerente e razoável. Mas, parece-me que há necessidade de a inviabilidade da rescisória ser prevista expressamente, pois não decorre do sistema processual. As previsões expressas nas leis de controle perante o STF viriam a corroborar essa tese. ${ }^{484}$

ocorrência do vício imaginado. Como a lei federal não se aplica diretamente ao processo perante os tribunais estaduais, restaria saber se a vedação quanto à irrescindibilidade incidiria nesta esfera.

${ }^{483}$ PALU, Oswaldo Luiz. Controle de constitucionalidade: Conceitos, sistemas e efeitos. $2^{\text {a }}$ ed., São Paulo, Revista dos Tribunais, 2001, p. 236-237.

${ }^{484} \mathrm{O}$ artigo art. 26 da Lei $\mathrm{n}^{\circ}$ 9.868/99 e, de maneira análoga, o art. 12, da Lei ${ }^{\circ}$ 9.882/99, dispõem que as decisões acerca do reconhecimento de constitucionalidade, inconstitucionalidade ou descumprimento de preceito fundamental não estão sujeitas à ação rescisória. 


\section{Conclusão}

A ideia de controlar a validade das leis contrárias ao sentimento de justiça de uma comunidade parece estar presente em toda a história da humanidade. Já na Grécia antiga, pode-se citar o exemplo do graphé paranomón como uma forma de extirpar do ordenamento jurídico as leis que afrontassem o direito superior daquela comunidade, identificado no Direito divino e imutável.

No mesmo sentido, na época medieval, as leis contrárias ao Direito natural eram consideradas inexistentes e desprovidas de eficácia. Todavia, inexistia um mecanismo hábil a retirar essas normas do ordenamento jurídico, evidenciando-se aí uma dificuldade em fazer esse controle.

Embora tenha havido uma experiência prévia, na Inglaterra, no século XVII, durante o fugaz governo republicano, o controle da validade das leis só pôde ser efetivamente desenvolvido com o aparecimento das Constituições documentais e rígidas, fruto das Revoluções Liberais do século XVIII.

De fato, tanto na França como nos Estados Unidos da América, as Constituições representaram a condensação dos valores mais caros àquelas comunidades, alçados a um documento escrito. Se esses princípios e valores retratados nas Constituições eram os mais significativos, não poderiam ser colocados de lado, seja pela atividade administrativa, seja pelo legislador ordinário que, exercendo uma atividade delegada, não poderia extrapolar os limites da delegação conferida pelo legislador originário (o Poder Constituinte originário).

Os idealizadores dessa nova ordem jurídica, tanto na França, como na América, já tinham bem clara a necessidade da instituição de um órgão destinado à proteção da Constituição, como bem demonstram as obras de SIEYÈS e os Artigos Federalistas. 
Devido às particularidades do processo de formação dos Estados Unidos da América, o controle de constitucionalidade das leis desenvolveu-se ali de uma maneira espontânea, na prática judiciária. De fato, em diversas decisões, em fins do Século XVIII, cortes estaduais invalidaram leis locais reputando-as contrárias à Constituição do Estado respectivo. O caso emblemático, MARBURY versus MADISON, todavia, ocorreu em 1803, quando a Suprema Corte invalidou uma lei federal por contrariedade à Constituição americana.

Pode-se, assim, dizer que nos moldes atuais, o controle de constitucionalidade surgiu na América, decorrente do exercício da atividade jurisdicional, na qual o órgão - qualquer órgão - do Poder Judiciário, ao analisar um caso concreto - isto é, um litígio entre partes - poderia verificar a compatibilidade entre a lei que embasa a relação jurídica controvertida e a Constituição e, se for o caso, declará-la inconstitucional.

Esse sistema, contudo, não foi, inicialmente, incorporado aos ordenamentos jurídicos dos Estados europeus, por resistência à ideia de um controle realizado por um órgão do Poder Judiciário, nem sempre bem visto naqueles Países e em decorrência da ausência de precedentes vinculantes naqueles Estados, dentre outros fatores. Assim, até o início do século XX, poucos Estados europeus haviam implantado um sistema de controle de constitucionalidade.

Vislumbrando a importância da adoção de um mecanismo voltado a controlar a constitucionalidade das leis e, ao mesmo tempo, tentando contornar a repulsa europeia à realização dessa atividade pelo Poder Judiciário, HANS KELSEN concebeu a ideia de um órgão independente dos Poderes Legislativo, Executivo e Judiciário, ao qual caberia, de forma isenta e imparcial, a análise da conformidade entre as leis e a Constituição. Sob o ponto de vista do produto dessa análise, a atividade desse órgão assemelhar-se-ia à legislativa, vista aqui como legislação negativa ou de revogação da lei, ideia que contribuía para afastar as críticas ao controle realizado pelo Judiciário. 
Esse sistema, implantado inicialmente na Constituição da Áustria de 1920 (depois aprimorado na Constituição austríaca de 1929), foi paulatinamente sendo incorporado pelo ordenamento dos demais países da Europa continental e mesmo fora daquele Continente.

Em decorrência da ideia de legislador negativo, muitos entenderam que as normas do processo jurisdicional não deveriam ser aplicadas ao processo desenvolvido pelo Tribunal Constitucional, ou órgão a ele correspondente, em sua tarefa de controle de constitucionalidade. Também no Brasil, onde um sistema de inspiração kelseniana foi implantado em 1965, por Emenda à Constituição de 1946, e reproduzido nas demais Constituições, inclusive na atual, a concepção da especialidade do processo do controle abstrato de constitucionalidade foi muito marcante, tendo sido revelada em diversos acórdãos do Supremo Tribunal Federal.

Deveras, na jurisprudência do STF encontram-se julgados afirmando, por exemplo, que, devido ao caráter especialíssimo do processo de controle abstrato, não é admitida a intervenção de terceiros, não se aplicam as normas referentes ao impedimento e à suspeição, não é cabível o ajuizamento de ação rescisória para desconstituir os seus acórdãos e não se aplicam os prazos estendidos para a interposição de recursos por parte de entes públicos. Mesmo princípios de índole constitucional, como o do contraditório, tiveram a sua incidência contestada no controle principal de constitucionalidade.

Procurei demonstrar no presente trabalho que muitas das noções acima apontadas não são consequências necessárias da especialidade do processo de controle abstrato de constitucionalidade e que, algumas delas, como, v. g., o afastamento do princípio do contraditório, além de não decorrerem da especialidade do processo, acabam por afrontar o próprio texto constitucional pátrio, que prevê expressamente a incidência daquele princípio em toda espécie de processo.

Assim, pode-se chegar a uma primeira conclusão, no sentido de que as normas processuais de índole constitucional devem, salvo previsão expressa em 
contrário, ou evidente incompatibilidade, ser aplicadas ao processo do controle abstrato de constitucionalidade. Por esse motivo, o processo voltado ao controle deve observar o princípio do contraditório, do devido processo legal, da publicidade, da motivação das decisões e da reserva de plenário, v.g.

Por outro lado, almejei também esclarecer que, apesar de suas inegáveis peculiaridades e especificidades, o processo de controle principal de constitucionalidade não deixa de ser um processo de índole jurisdicional. Embora contestada por alguns, essa natureza não foi negada sequer por KELSEN, que aceitava naturalmente a utilização do procedimento jurisdicional para a realização do controle por parte da Corte Constitucional.

Admitindo que a atividade realizada pela Corte Constitucional é de caráter jurisdicional, pretendi demonstrar que alguns dos mais importantes princípios processuais que a informam, hauridos muitas vezes em séculos de prática jurisdicional, poderiam, se aplicados ao controle abstrato de constitucionalidade, trazer sensíveis benefícios ao seu processo.

Voltei-me, então, a investigar quais princípios processuais se aplicariam ao processo objetivo de controle e, ainda, a verificar que alguns desses princípios sofriam alguma espécie de transformação ao serem inseridos em seu contexto.

Cabe aqui uma segunda conclusão: o processo objetivo de controle de constitucionalidade é inegavelmente um processo de natureza especial, motivo pelo qual a aplicação dos institutos do processo comum, de natureza subjetiva, não pode ser feita de forma imediata e direta. A invocação das normas dos processos comuns deve ser feita, portanto, de forma supletiva e desde que não afronte a especialidade do processo objetivo.

Por fim, verifiquei que o processo objetivo possui princípios próprios, só a ele aplicáveis, em decorrência de sua natureza especial. 
Assim, mediante a análise de cada um dos princípios que informam o processo de controle abstrato de constitucionalidade, verifica-se que alguns deles são extraídos da própria Constituição, outros retirados dos processos de índole comum e adaptados ao processo de controle abstrato e, finalmente, destacam-se princípios próprios, inerentes ao processo de natureza objetiva.

Concluo que a análise do processo de controle abstrato de constitucionalidade, sob o prisma dos princípios processuais, permite um melhor e mais aprofundado conhecimento desse mecanismo processual e contribui, dessa forma, para que o seu manejo se realize com maior segurança e clareza. Sendo certo que os mecanismos processuais permitem o exercício dos próprios direitos constitucionais, percebe-se, com facilidade, a importância do processo, como meio de acesso à Constituição e à implementação prática de seus institutos. Ao elucidar o processo de controle abstrato de normas, espero contribuir, em alguma medida, para o exercício de uma democracia participativa e aberta, que caracterize o Brasil como um verdadeiro Estado democrático de Direito. 


\section{REFERÊNCIAS BIBLIOGRÁFICAS}

ALEXY, Robert. Teoria dos Direitos Fundamentais. tradução Virgílio Afonso da Silva, São Paulo, Malheiros, 2008.

ALMADA, Roberto José Ferreira de. A garantia processual de publicidade. São Paulo, Revista dos Tribunais, 2005.

AMARAL JÚNIOR, José Levi Mello do. Incidente de argüição de inconstitucionalidade. São Paulo, Revista dos Tribunais, 2002.

ANGIOLINI, Vittorio. Il contraddittorio nel giudizio sulle legge. In: Il contraddittorio nel giudizio sulle legge: atti Del seminário di Milano svoltosi Il 16 e 17 maggio 1997. Torino, G. Giappichelli, p. 3-26, 1998.

ATALIBA, Geraldo. República e Constituição. $2^{a}$ ed., São Paulo, Malheiros, 2004.

ÁVILA, Humberto. Teoria dos Princípios, da definição à aplicação dos princípios jurídicos. $7^{\mathrm{a}}$ ed., São Paulo, Malheiros, 2007.

BACHOF, Otto. Normas Constitucionais Inconstitucionais? Coimbra, Livraria Almedina, 1994.

BARACHO, José Alfredo de Oliveira. Direito processual constitucional: Aspectos contemporâneos. Editora Fórum, Belo Horizonte, 2006.

BARBOSA MOREIRA, José Carlos. O novo processo civil brasileiro. $27^{\mathrm{a}}$ ed., Rio de Janeiro, Forense, 2009.

A motivação das decisões judiciais como garantia inerente ao Estado de Direito. In: Temas de direito processual, Segunda Série. São Paulo, Saraiva, 1980, p. 83-95.

BARBOSA, Rui. Atos Inconstitucionais. Atualização Ricardo Rodrigues Gama, 2a ed., Campinas, Russel, 2004. 
BARBOSA SOBRINHO, Osório Silva. Comentários à Lei n. 9.868/99: Processo do controle concentrado de constitucionalidade. São Paulo, Saraiva, 2004.

BARCELlOS, Ana Paula de; BARROSO, Luiz Roberto. O Começo da História: A Nova Interpretação Constitucional e o Papel dos Princípios no Direito Brasileiro. In: Revista de Direito Administrativo, v. 232. Rio de Janeiro, abril/junho, p. 141-176, 2003.

BARROSO, Luiz Roberto. Interpretação e aplicação da Constituição. São Paulo, Saraiva, 1996.

O Controle de constitucionalidade no direito brasileiro. $2^{\mathrm{a}}$ ed., São Paulo, Saraiva, 2006.

BASTOS, Celso Ribeiro. Hermenêutica e interpretação constitucional. São Paulo, Celso Bastos Editor, 1997.

; MEYER-PFLUG, Samantha. Desenvolvimento e Atualização das Normas Constitucionais. In: SILVA, Virgílio Afonso da (org.). Interpretação Constitucional. $1^{\mathrm{a}}$ ed., $2^{\mathrm{a}}$ tiragem, São Paulo, Malheiros, p. 145-164, 2005.

Peculiaridades Justificantes de uma Hermenêutica Constitucional. In: Cadernos de Direito Constitucional e Ciência Política. São Paulo, Revista dos Tribunais, ano 5, $\mathrm{n}^{0}$ 21, outubro-dezembro, p 40-53, 1997.

O controle judicial da constitucionalidade das leis e atos normativos municipais. In: CENTRO DE ESTUDOS DA PROCURADORIA GERAL DO ESTADO DE SÃO PAULO. Ação direta de controle de constitucionalidade de leis municipais, em tese. Revista da Procuradoria-Geral do Estado de São Paulo. São Paulo, p. 67-77, 1979.

BEDAQUE, José Roberto dos Santos. Poderes instrutórios do juiz. $4^{\mathrm{a}}$ ed., São Paulo, Revista dos Tribunais, 2009.

BENTHAM, Jeremy. Rationale of judicial evidence, specially applied to English practice, v. 1. Londres, Hunt and Clarke, 1827, p. 530. Disponível em: $<$ http://books.google.com.br/books?ei=Muy7SpGADZautgfPntXDDQ\&ct=result\&q=Rational 
$\underline{\mathrm{e}+\text { of }+ \text { judicial+evidence:+especially }+ \text { applied }+ \text { to }+ \text { English }+ \text { practice },+ \text { Volume }+1 \& \text { spell }=1 \& o i=s}$ pell> Acesso em 05/01/2010.

BERNARDES, Juliano Taveira. Controle Abstrato de Constitucionalidade. Elementos materiais e princípios processuais. São Paulo, Saraiva, 2004.

BIANCHI, Paolo. Il contraddittorio davanti alla corte suprema degli stati uniti. In: ANGIOLINI, Vittorio, Il contraddittorio nel giudizio sulle legge: atti Del seminário di Milano svoltosi Il 16 e 17 maggio 1997. Torino, G. Giappichelli, p. 279-327, 1998.

BITTENCOURT, C. A. Lúcio. O Contrôle Jurisdicional da Constitucionalidade das Leis. $2^{\mathrm{a}}$ ed., Forense, Rio de Janeiro, 1968.

BONAVIDES, Paulo. Curso de direito constitucional. 7. ed., São Paulo, Malheiros, 1997.

BRANCO, Paulo Gustavo Gonet. Juízo de ponderação na jurisdição constitucional. São Paulo, Saraiva, 2009.

BUZAID, Alfredo. Da ação direta de declaração de inconstitucionalidade no direito brasileiro. São Paulo, Saraiva, 1958.

CABIDDU, Maria Agostina. Autorità e liberta davanti alla corte costituzionale. In: ANGIOLINI, Vittorio. Il contraddittorio nel giudizio sulle legge: atti Del seminário di Milano svoltosi Il 16 e 17 maggio 1997. Torino, G. Giappichelli, p. 379-400, 1998.

CAMPILONGO, Celso Fernandes. Política, Sistema Jurídico e Decisão Judicial. São Paulo, Max Limonad, 2002.

Democracia e direito. $2^{\mathrm{a}}$ ed., São Paulo, Max Limonad, 2000.

CANAS, Vitalino. Os processos de fiscalização da constitucionalidade e da legalidade pelo tribunal constitucional. Coimbra, Coimbra Editora, 1986.

CANOTILHO, José Joaquim Gomes. Direito constitucional e teoria da Constituição. $7^{\mathrm{a}}$ ed., Coimbra, Livraria Almedina, 2003. 
. Estudos sobre Direitos Fundamentais. $1^{\mathrm{a}}$ ed. brasileira, $2^{\mathrm{a}}$ ed. portuguesa, São Paulo, Coimbra Editora e Revista dos Tribunais, 2008.

Direito constitucional. 6a ed., Coimbra, Almedina, 1993.

CAPPELLETTI, Mauro. O controle judicial de constitucionalidade das leis no direito comparado. $2^{\text {a }}$ ed., Porto Alegre, Sérgio A. Fabris, Editor, 1999.

CARVALHO, Kildare Gonçalves. Direito Constitucional. Belo Horizonte. Del Rey, 2006.

CHIOVENDA, Giuseppe. Instituições de Direito Processual Civil. Tradução Paolo Capitanio, v. 2 e 3, $1^{\text {a }}$ edição, Campinas, Bookseller, 1998.

CINTRA, Antonio Carlos de Araújo; GRINOVER, Ada Pellegrini; DINAMARCO, Cândido Rangel. Teoria geral do processo. 25ª ed., São Paulo, Malheiros, 2009.

CLÈVE, Clèmerson Merlin. A fiscalização abstrata de constitucionalidade no direito brasileiro. $2^{a}$ ed., São Paulo, Revista dos Tribunais, 2000.

COELHO, Inocêncio Mártires. Interpretação constitucional. Porto Alegre, Sérgio A. Fabris, Editor, 1997.

COMPARATO, Fábio Konder. A afirmação histórica dos direitos humanos. São Paulo, Saraiva, 1999.

CONCARO, Alessandra. Il Conseil Constitutionnel francese: verso um "contraddittorio" ufficiale? In: ANGIOLINI, Vittorio, Il contraddittorio nel giudizio sulle legge: atti Del seminário di Milano svoltosi Il 16 e 17 maggio 1997. Torino, G. Giappichelli, p. 440-447, 1998.

CORREIA, Marcus Orione Gonçalves. Direito processual constitucional. São Paulo, Saraiva, 1998. 
CRUZ E TUCCI, José Roberto. Garantias Constitucionais do Processo Civil. São Paulo, RT, 1999.

DALLARI, Dalmo de Abreu. O poder dos juízes. São Paulo, Saraiva, 1996.

. Lei municipal inconstitucional. In: CENTRO DE ESTUDOS DA PROCURADORIA GERAL DO ESTADO DE SÃO PAULO. Ação direta de controle de constitucionalidade de leis municipais, em tese. Revista da Procuradoria-Geral do Estado de São Paulo. São Paulo, p. 115-126, 1979.

DANTAS, Ivo. Constituição \& Processo. 2a ed., Curitiba, Juruá Editora, 2007.

DELFIM, Ricardo Alessi. Ação Declaratória de Constitucionalidade e os Princípios Constitucionais do Processo. São Paulo, 2001.

DINAMARCO, Cândido Rangel. A Instrumentalidade do Processo. $13^{\mathrm{a}}$ ed., São Paulo, Malheiros, 2008.

Instituições de direito processual civil, v. I e II. $6^{\text {a }}$ ed., São Paulo, Malheiros, 2009.

Teoria Geral do Processo. 25ª ed., São Paulo, Malheiros, 2009.

Vocabulário do processo civil. São Paulo, Malheiros, 2009.

DUTRA, Carlos Roberto de Alckmin. O Controle Estadual de Constitucionalidade de Leis e Atos Normativos. São Paulo, Saraiva, 2005.

DWORKIN, Ronald. Uma questão de princípio. São Paulo, Martins Fontes, 2005.

Levando os Direitos a Sério. São Paulo, Martins Fontes, 2007.

FAVOREU, Louis. As Cortes Constitucionais. São Paulo, Landy Editora, 2004. 
FERnANDES, Antonio Carlos Scarance. Processo Penal Constitucional. $3^{\text {a }}$ ed., RT, São Paulo, 2002.

FERRARI, Regina Maria Macedo Nery. Efeitos da declaração de inconstitucionalidade. $5^{\mathrm{a}}$ ed., rev. e ampl., São Paulo, Revista dos Tribunais, 2004.

FERRAZ JUNIOR, Tercio Sampaio. Introdução ao Estudo do Direito: Técnica, Decisão e Dominação. São Paulo, Atlas, 1996.

FERREIRA FILHO, Manoel Gonçalves. Curso de direito constitucional. 32a ed., São Paulo, Saraiva, 2006.

O poder constituinte. $5^{\text {a }}$ ed., São Paulo, Saraiva, 2007.

Direitos humanos fundamentais. São Paulo, Saraiva, 1995.

Aspectos do direito constitucional contemporâneo. 2a ed., São Paulo, Saraiva, 2009.

O Sistema Constitucional e as Recentes Inovações no Controle de Constitucionalidade (Leis $\mathrm{n}^{\circ}$ 9.868, de 10 de Novembro e $\mathrm{n}^{\circ}$ 9.882, de 3 de dezembro de 1989). In: Revista de Direito Administrativo. Rio de Janeiro, 220: 1-17, abr./jun. 2000.

Comentários à Constituição brasileira. 4ª ed., São Paulo, Saraiva, 1983.

GARCÍA DE ENTERRIA, Eduardo. La Constitucion Como Norma y el Tribunal Constitucional. Tercera Edición, Madri, 1994.

GRAU, Eros Roberto. Ensaio e discurso sobre a interpretação/aplicação do direito. $3^{\mathrm{a}}$ ed., São Paulo, Malheiros, 2005.

GUERRA FILHO, Willis Santiago. Processo constitucional e direitos fundamentais. $5^{\mathrm{a}}$ ed., São Paulo, RCS Editora, 2007. 
GRINOVER, Ada Pellegrini. A ação direta de controle da constitucionalidade na Constituição paulista. In: CENTRO DE ESTUDOS DA PROCURADORIA GERAL DO ESTADO DE SÃO PAULO. Ação direta de controle de constitucionalidade de leis municipais, em tese. Revista da Procuradoria-Geral do Estado. São Paulo, Centro de Estudos, p. 51-66, 1979.

A Garantia Constitucional do Direito de Ação e sua Relevância no Processo

Civil. 1972, (livre docência em Direito Judiciário Civil) - Faculdade de Direito, Universidade de São Paulo, São Paulo, 1972.

HÄBERLE, Peter. Hermenêutica constitucional: A sociedade aberta dos intérpretes da Constituição: contribuição para a interpretação pluralista e procedimental da Constituição. Tradução Gilmar Ferreira Mendes, Porto Alegre, Sérgio A. Fabris, Editor, 1997.

HESSE, Konrad. A força normativa da Constituição. Tradução Gilmar Ferreira Mendes, Porto Alegre, Sérgio A. Fabris, Editor, 1991.

HOBBES, Thomas. Leviatã. São Paulo, Abril Cultural, 1974.

HORTA, Raul Machado. Estudos de direito constitucional. Belo Horizonte, Del Rey, 1995.

KELSEN, Hans. Jurisdição Constitucional. São Paulo, Martins Fontes, 2003.

Teoria Pura do Direito. São Paulo, Martins Fontes, 2006.

LALANDE, André. Vocabulário técnico e crítico da filosofia. São Paulo, Martins Fontes, 1993.

LEAL, Roger Stiefelmann. O Efeito Vinculante na Jurisdição Constitucional. São Paulo, Saraiva, 2006.

LIMA, Christina Aires Correa. Os efeitos da declaração de inconstitucionalidade da lei perante o Supremo Tribunal Federal. In: Cadernos de Direito Constitucional e Ciência Política. São Paulo, Revista dos Tribunais, nº 27, abr./jun., 1999. 
LOUREIRO, Lair da Silva; LOUREIRO FILHO, Lair da Silva. Ação direta de inconstitucionalidade: jurisprudência do Órgão Especial do Tribunal de Justiça do Estado de São Paulo 1986/1995. São Paulo, Saraiva, 1996.

LUHMANN, Niklas. Legitimação pelo Procedimento. Brasília, Editora Universidade de Brasília, 1980.

LUTHER, Jörg. Il contraddittorio nei procedimenti della normenkontrolle tedesca. In: ANGIOLINI, Vittorio. Il contraddittorio nel giudizio sulle legge: atti Del seminário di Milano svoltosi Il 16 e 17 maggio 1997. Torino, G. Giappichelli, p. 343-355, 1998.

MARINONI, Luiz Guilherme. Teoria Geral do Processo. $3^{\mathrm{a}}$ ed., São Paulo, Revista dos Tribunais, 2008.

Novas Linhas do Processo Civil. São Paulo, RT, 1993.

MARTINS, Ives Gandra da Silva; MENDES, Gilmar Ferreira. Controle concentrado de constitucionalidade: Comentários à Lei n. 9.868, de 10-11-1999. $3^{\text {a }}$ ed., São Paulo, Saraiva, 2009.

; MENDES, Gilmar Ferreira. (coords.). Ação Declaratória de Constitucionalidade. São Paulo, Saraiva, 1995.

MELLO, Celso Antônio Bandeira de. Curso de Direito Administrativo. 24a ed., São Paulo, Malheiros, 2007.

MENDES, Gilmar Ferreira. Jurisdição constitucional. 5ª ed., São Paulo, Saraiva, 2005.

Controle de Constitucionalidade: Aspectos jurídicos e políticos. São Paulo, Saraiva, 1990.

Moreira Alves e o controle de constitucionalidade no Brasil. São Paulo, Celso Bastos Editor, 2000. 
Saraiva, 2006.

Direitos Fundamentais e Controle de Constitucionalidade. $3^{\text {a }}$ ed., São Paulo, Arguição de descumprimento de preceito fundamental. São Paulo, Saraiva, 2007.

MIRANDA, Jorge. Contributo para uma teoria da inconstitucionalidade. Coimbra, Coimbra Ed., 1996.

Manual de Direito Constitucional, t. VI: Inconstitucionalidade e garantia da Constituição. $3^{\mathrm{a}}$ ed., Coimbra, Coimbra Editora, 2008.

MEYER-PFLUG, Samanta. Desenvolvimento e Atualização das Normas Constitucionais. In: SILVA, Virgílio Afonso da (org.). Interpretação Constitucional. $1^{\mathrm{a}}$ ed., $2^{\mathrm{a}}$ tiragem São Paulo, Malheiros, p. 145-164, 2005.

MONTESQUIEU, Charles de Secondat. O Espírito das Leis. Tradução Cristina Murachco, São Paulo, Martins Fontes, 1996.

MORAES, Alexandre de. Jurisdição Constitucional e Tribunais Constitucionais: Garantia Suprema da Constituição. São Paulo, Atlas, 2000.

Direito Constitucional. 9a ed., São Paulo, Atlas, 2001.

Direitos Humanos Fundamentais. 6a ed., São Paulo, Atlas, 2005.

Comentários à Lei $\mathbf{n}^{\circ} \mathbf{9 . 8 8 2} / 99$ - Argüição de descumprimento de preceito

fundamental. In: TAVARES, André Ramos; ROTHENBURG, Walter Claudius (orgs.), Arguição de descumprimento de preceito fundamental: análises à luz da Lei $n^{0}$ 9.882/99. São Paulo, Atlas, p. 15-37, 2001.

NASCIMENTO FILHO, Firly. Da ação direta de declaração de inconstitucionalidade: atuação da Mesa da Assembléia Legislativa. Rio de Janeiro, Lumen Juris, 1996.

NEBRERA, Montserrat. El principio de contradicción El los processos de control de La 
constitucionalidad de las leyes en España. In: ANGIOLINI, Vittorio. Il contraddittorio nel giudizio sulle legge: atti Del seminário di Milano svoltosi Il 16 e 17 maggio 1997. Torino, G. Giappichelli, p. 329-342, 1998.

NERY JUNIOR, Nelson. Princípios do Processo Civil na Constituição Federal. 9a ed., Revista dos Tribunais, São Paulo, 2009.

; NERY, Rosa Maria de Andrade. Constituição Federal comentada e legislação constitucional. São Paulo, Revista dos Tribunais. 2006.

OLIVIERI, Laura. Principio inquisitório e contraddittorio nel giudizio di constituzionalità delle leggi. In: ANGIOLINI, Vittorio. Il contraddittorio nel giudizio sulle legge: atti Del seminário di Milano svoltosi Il 16 e 17 maggio 1997. Torino, G. Giappichelli, p. 507-529, 1998.

PALU, Oswaldo Luiz. Controle de constitucionalidade: Conceitos, sistemas e efeitos. $2^{\mathrm{a}}$ ed., São Paulo, Revista dos Tribunais, 2001.

PIOVESAN, Flávia Cristina. Proteção constitucional contra omissões legislativas. São Paulo, Revista dos Tribunais, 1995.

RAMOS, Elival da Silva. Perspectivas de evolução do controle de constitucionalidade no Brasil. 2005, 466 f., tese (provimento de cargo de professor titular), Universidade de São Paulo, Faculdade de Direito, Departamento de Direito do Estado - Direito Constitucional, São Paulo, 2005.

A inconstitucionalidade das leis: vício e sanção. São Paulo, Saraiva, 1994.

. O direito de ação como direito político. In: GRINOVER, Ada Pellegrini; DINAMARCO, Cândido Rangel; WATANABE, Kazuo (coords.). Participação e Processo. Coord. São Paulo, Revista dos Tribunais, 1988.

A Proteção dos Direitos Adquiridos no Direito Constitucional Brasileiro. São Paulo, Saraiva, 2003.

REALE, Miguel. Lições Preliminares de Direito. 18ª ed., São Paulo, Saraiva, 1991. 
ROTHENBURG, Walter Claudius. Princípios Constitucionais. 2 ${ }^{\mathrm{a}}$ tiragem, Porto Alegre, Sergio Fabris Editor, 2003.

Argüição de descumprimento de preceito fundamental. In: TAVARES, André Ramos (orgs.). Argüição de descumprimento de preceito fundamental à luz da Lei no 9.882/99. São Paulo, Atlas, p. 198-236, 2001.

ROUSSEAU, Jean-Jacques. O Contrato Social e Outros Escritos, $15^{\mathrm{a}}$ ed., São Paulo, Cultrix, 2005.

RUGGERI, Antonio. In tema di contraddittorio e process costituzionale, ovvero del "pluralismo" nei giudizi sulle leggi quale condizione della "costituzionalità" del processo. In: ANGIOLINI, Vittorio. Il contraddittorio nel giudizio sulle legge: atti Del seminário di Milano svoltosi il 16 e 17 maggio 1997. Torino, G. Giappichelli, p. 555-569, 1998.

SARMENTO, Daniel. Apontamentos sobre a argüição de descumprimento de preceito fundamental. In: TAVARES, André Ramos; ROTHENBURG, Walter Claudius (orgs.), Arguição de descumprimento de preceito fundamental: análises à luz da Lei $n^{0}$ 9.882/99. São Paulo, Atlas, p. 85-108, 2001.

SARTORI, Gionvanni. A teoria da democracia revisitada, v. II: As questões clássicas. São Paulo, Atlas, 1994.

SCHMITT, Carl. O Guardião da Constituição. Belo Horizonte, Del Rey, 2007.

SCHWARTZ, Bernard. Direito Constitucional Americano. Rio de Janeiro, Forense, 1955.22

SIEYÈS, Emmanuel Joseph. Qu'est-ce que lê Tiers État?, $3^{\mathrm{a}}$ ed., Organização de Aurélio Wander Bastos, Rio de Janeiro, Lumen Juris, 1997.

SILVA, José Afonso da. Curso de direito constitucional positivo. 24a ed., São Paulo, Malheiros Editores, 2005. 
2007.

Processo constitucional de formação das lei. $2^{\mathrm{a}}$ ed., São Paulo, Malheiros,

Aplicabilidade das normas constitucionais. $3^{\mathrm{a}}$ ed. rev. ampl. e atual., São Paulo, Malheiros Ed., 1998.

Ação de declaração de inconstitucionalidade de lei municipal. In: CENTRO DE ESTUDOS DA PROCURADORIA GERAL DO ESTADO DE SÃO PAULO. Ação Direta de Controle de Constitucionalidade de Leis Municipais, em Tese. Revista da ProcuradoriaGeral do Estado. São Paulo, Centro de Estudos, p. 79-114, 1979.

SILVA, Virgílio Afonso da. Princípios e regras. In: Revista Latino-Americana de Estudos Constitucionais, $\mathrm{n}^{\circ} 1$, p. 607-630, 2003.

50, 2002.

O Proporcional e o razoável. São Paulo, Revista dos Tribunais, v. 798, p. 23-

TARUFO, Michele. Il significato costituzionale dell'obrigo di motivazione. In: GRINOVER, Ada Pellegrini; DINAMARCO, Cândido Rangel; WATANABE, Kazuo (orgs.). Participação e processo. São Paulo, Saraiva, p. 37-50, 1988.

TAVARES, André Ramos. Tribunal e jurisdição constitucional. São Paulo, Celso Bastos Editor, 1998.

Teoria da justiça constitucional. São Paulo. Saraiva, 2005.

Tratado da arguição de preceito fundamental. São Paulo, Saraiva, 2001.

Arguição de descumprimento de preceito fundamental: Análise à luz da Lei n 9 9.882/99, São Paulo, Atlas, 2001.

THEODORO JÚNIOR, Humberto. Curso de direito Processual Civil, v. I. 45 ed., Rio de Janeiro, Forense, 2006.

VATTEL, Emer de. O direito das gentes. Brasília, Instituto de Pesquisa de Relações 
Internacionais - Editora Universidade de Brasília, 2004.

VILHENA, Oscar. Supremo Tribunal Federal: jurisprudência política. São Paulo, Revista dos Tribunais, 1994.

ZAVASCKI, Teori Albino. Eficácia das sentenças na jurisdição constitucional. São Paulo, Revista dos Tribunais, 2001. 